\title{
نظري به:
}

\section{تاويخ قززلباشها دور أ فำ}

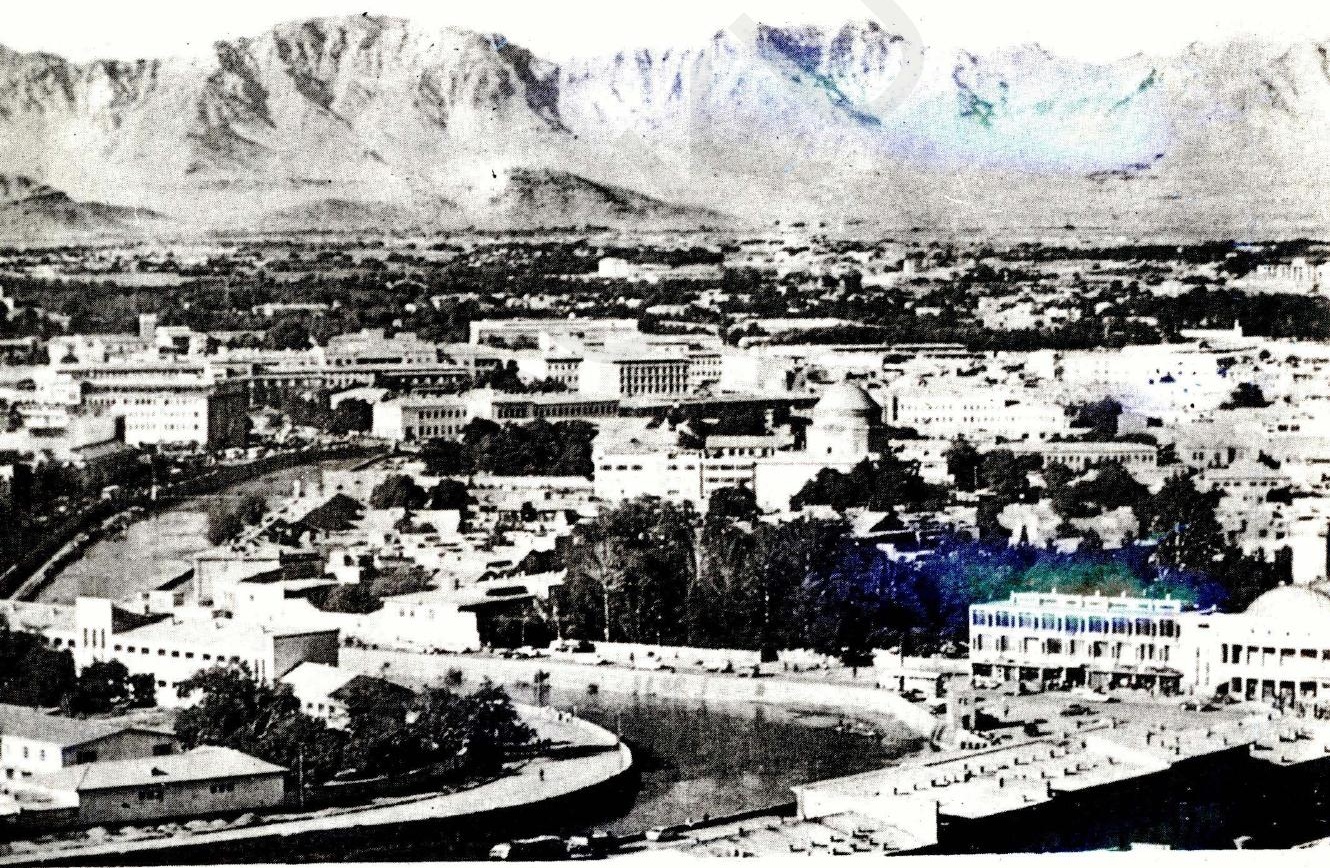

مؤلف: محمد احسان يزوهش 


\section{نظري به:}

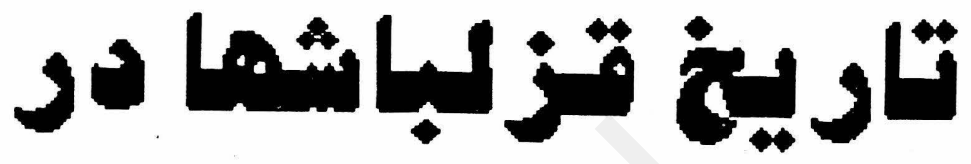

افغانستان
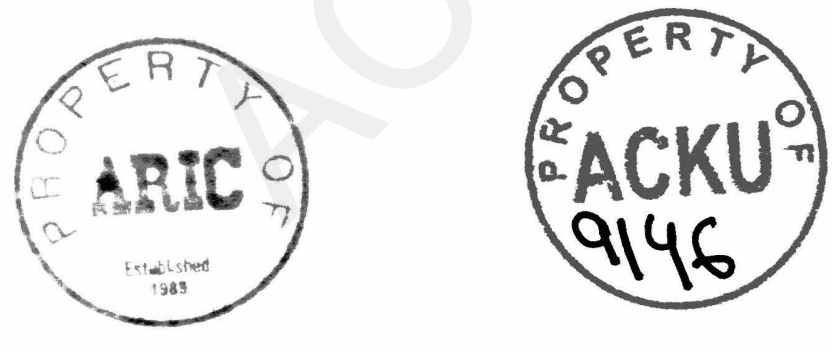

$$
\text { مؤلف: محمد احسان يُّزومش }
$$

Irva
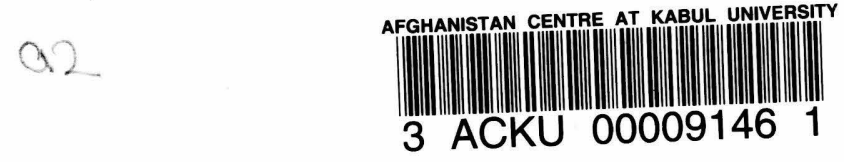
به دخترانم اناهيتا و تهمينه كه ملانند صد ما مزار كودك هموطن خويش ناكزير شده اند درسن بازي و تعليم، در

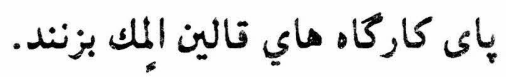

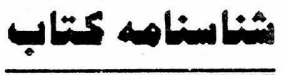

نـام كتــاب : نظري به تأريخ تزلباشها در افغانستان

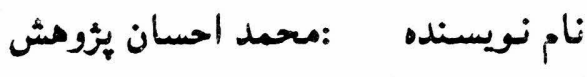

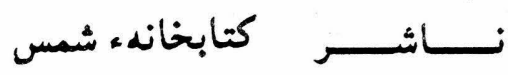

كــــــــوزر :غازى كميرزنخ سنتر (مصطفى سحر)

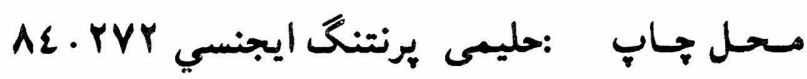

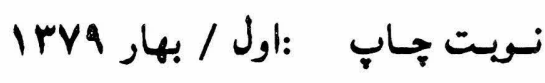
كليه حقوت براي ناشر محفوظ است 
فهرست مطالب

صفحه

1

0

9

10

IV

19

rr

rr

Y

ri

m

rr

$\varepsilon$.

\&r

29

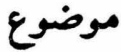

$$
\begin{aligned}
& \text { مدخل } \\
& \text { - مفهوم اقليت } \\
& 1 \\
& \text { منشاء نزرادي قزلباشها } \\
& \text { اقوال نادرست } \\
& \text { سخني درباره تركان } \\
& \text { نتيجه بحث } \\
& r \\
& \text { تزلباشان افغانستان } \\
& \text { آغاز ورود تزلباشان } \\
& \text { جابجايى تزلباشان } \\
& r \\
& \text { تزلباشان در اداره دولت } \\
& \text { علل جابجاي قزلباشان } \\
& \text { سهيم ساختن قزلباشان در اداره دولت } \\
& \text { توطئه ضد قزلباشان } \\
& \text { قزلباشان در موازنه قدرت } \\
& \text { برخي دولت مردان تزلباش }
\end{aligned}
$$




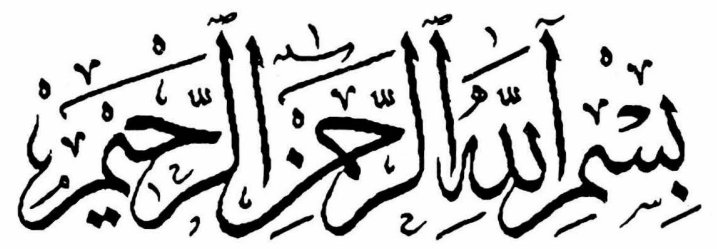

سخني با خواننده

مسوده اي يادداشت ماي كه به شكل كنوني تأليف كرديده، حدود دمسال بيش كردآوري شده بود.

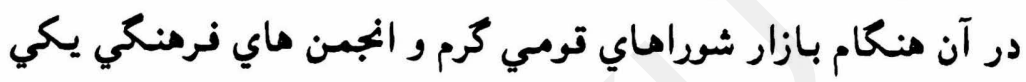

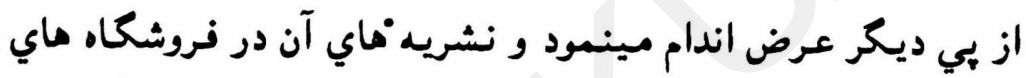

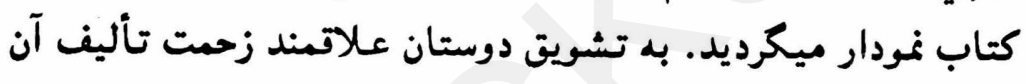

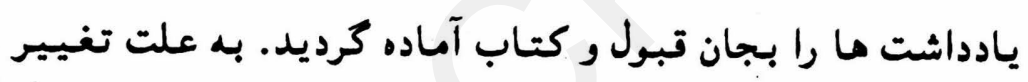

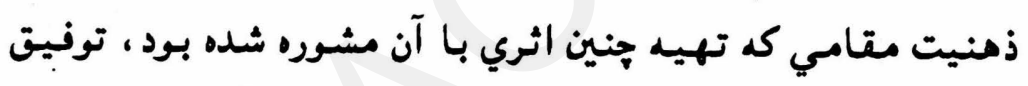

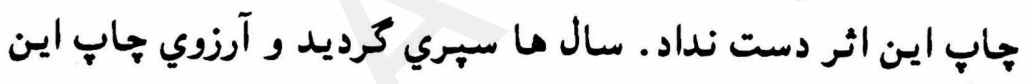

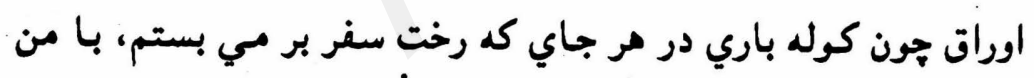

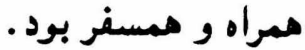

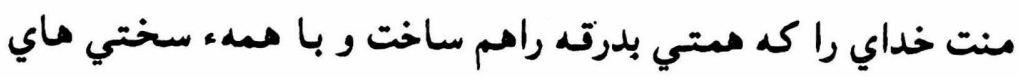

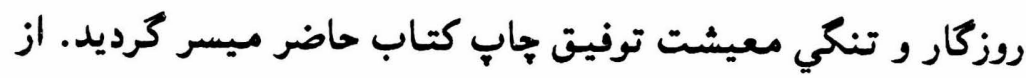

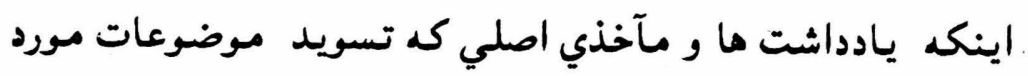

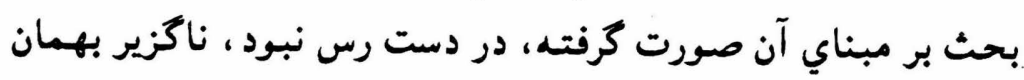


شكل اوليه آن به دست نشر سبرده شد. نويسنده آحاه است كد

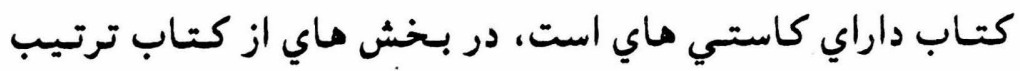
تاريخي مطالب رعايت نكرديده، موضوعات به دقت تبويب نشده و وري

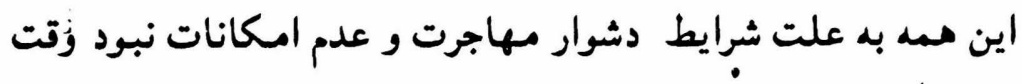

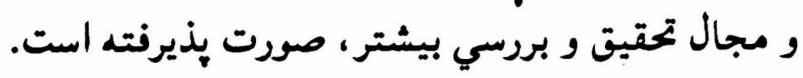

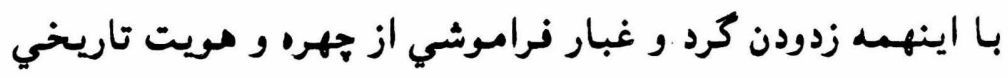

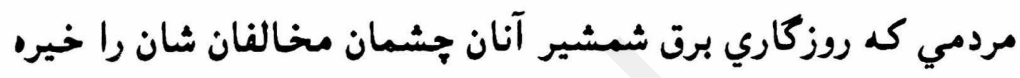

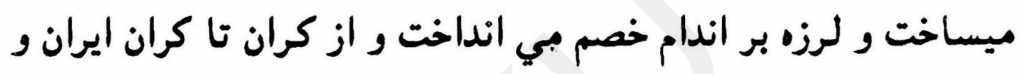

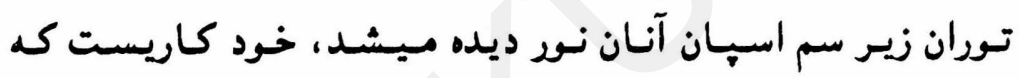
ميبايست صورت بذيرد.

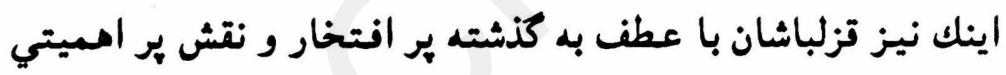

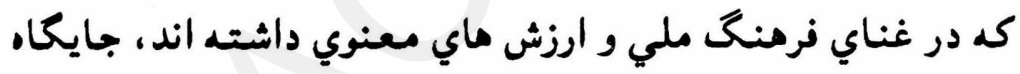
خويش را در جامعه انغاني در كنار ساير برادران مييابند و جشم

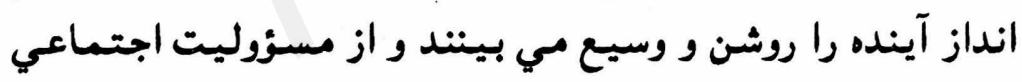

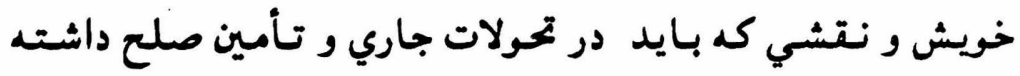
باشند، وقوف مي يابند. ناكفته هيداست كه مركاه مطالعه اين كتاب بتواند در خواننده حنين

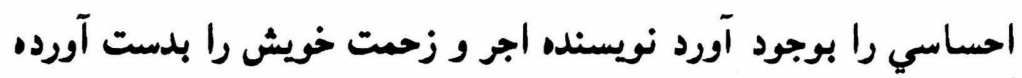




\section{مدخل}

افغانستان كشور كثير الاقوام است ـ در محدوده جغرافيائى آن

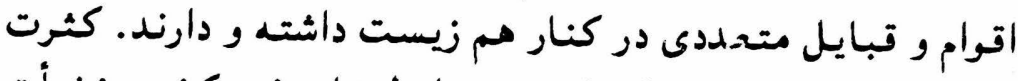

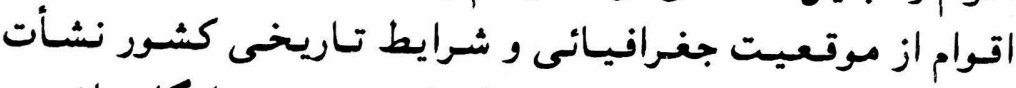

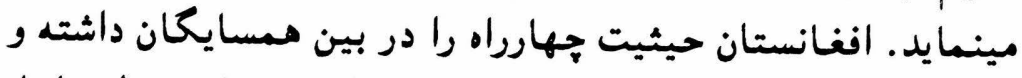

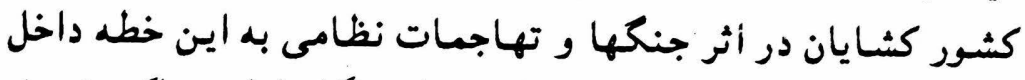

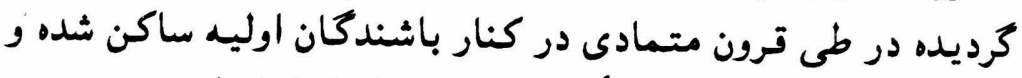

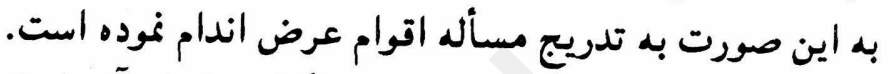

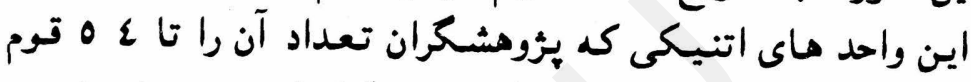

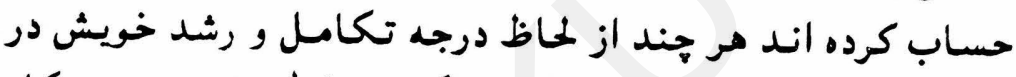

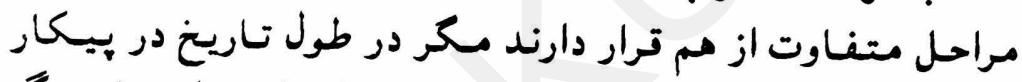

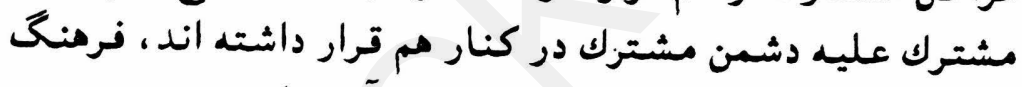
غنى و ارزشهاى معنوى مشتركى را بوجود آورده اند.

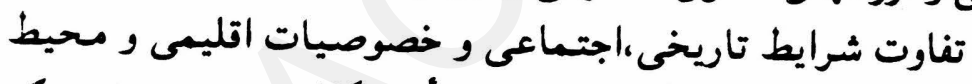

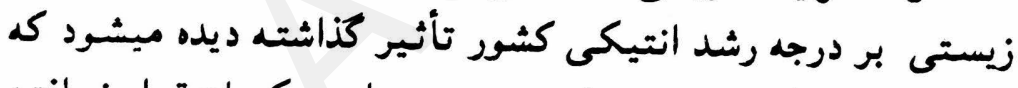

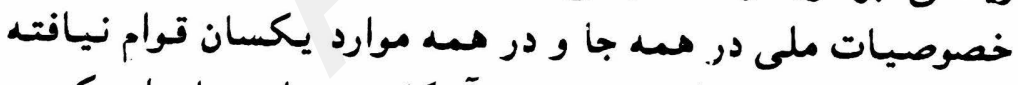

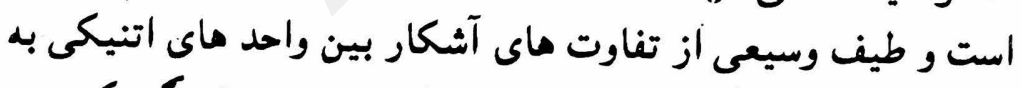

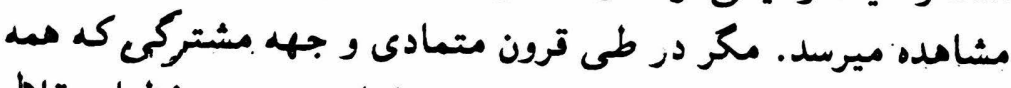

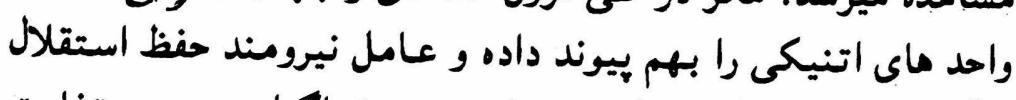

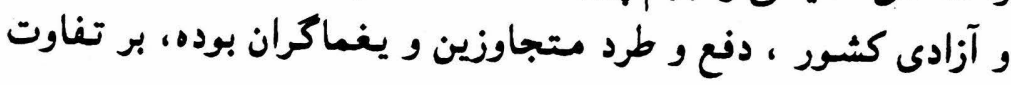
هاى اتنيكى هيروز كرديده است.

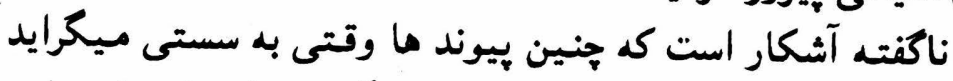

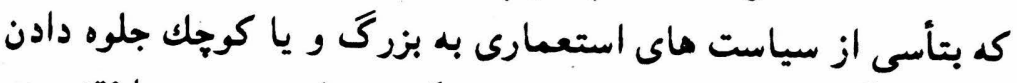

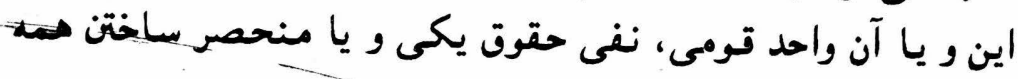




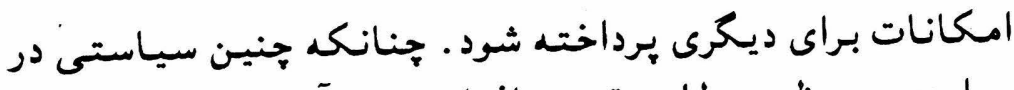

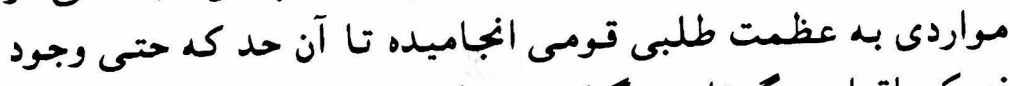
فزيكى اقوام ديكر ناديده كرفته شده است فيت فئ

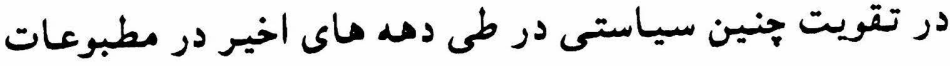

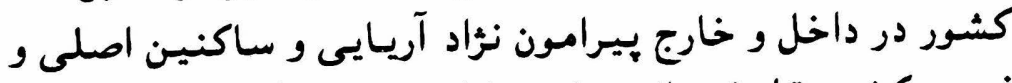

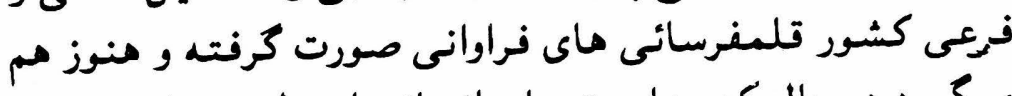

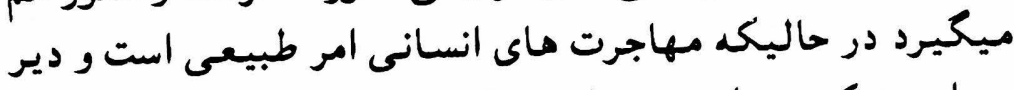

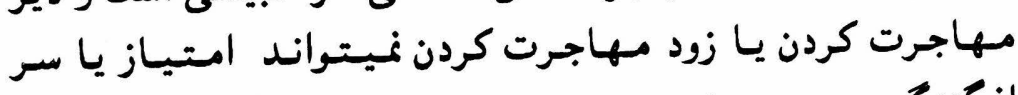

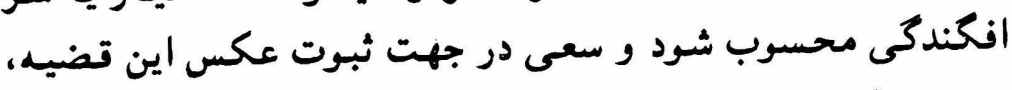
سعى عبث و بيهوده بيش نيست.

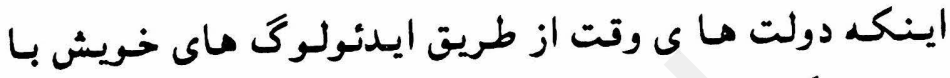

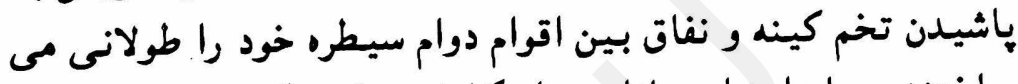

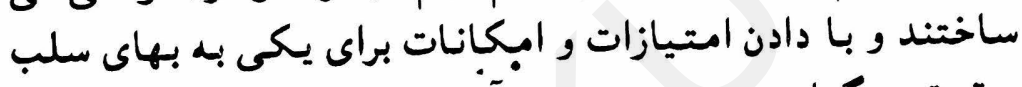

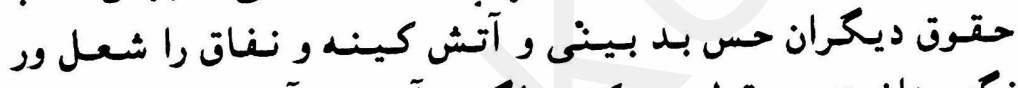

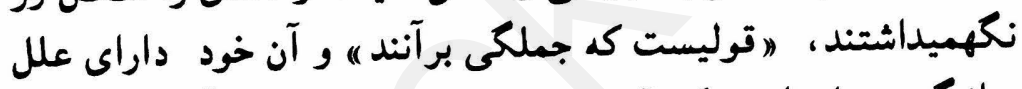

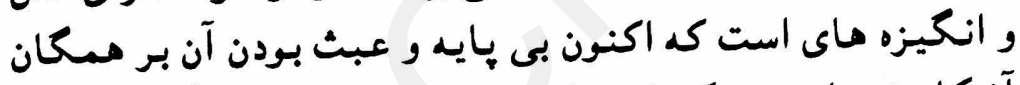

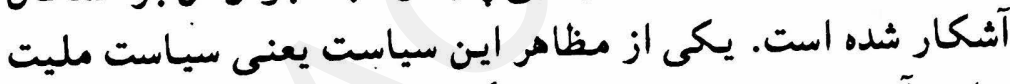

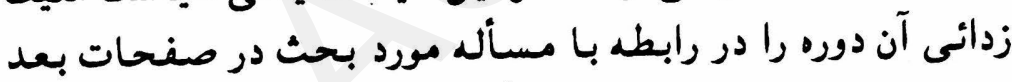

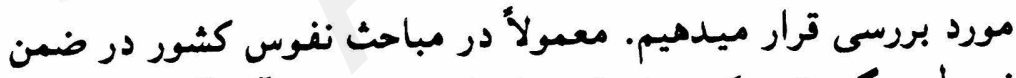

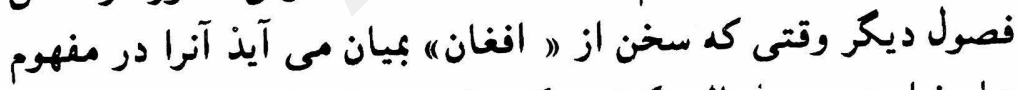

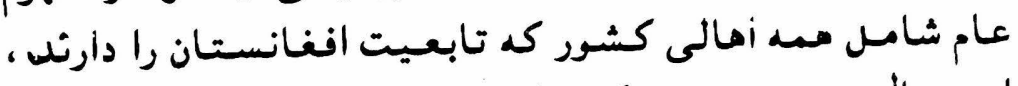

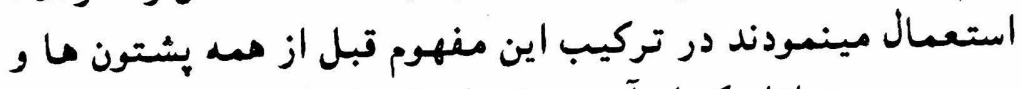

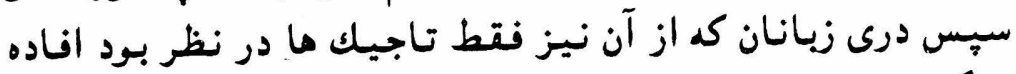

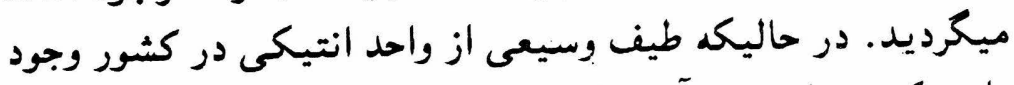

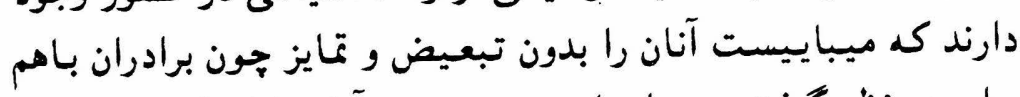

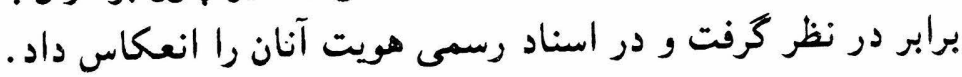


بعنوان نمونه يكى از واحد ماى اتنيكى كد تا كنون در هيج يك از

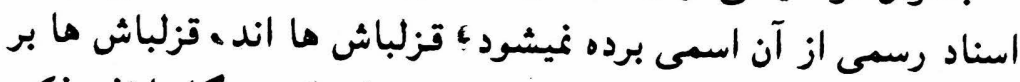

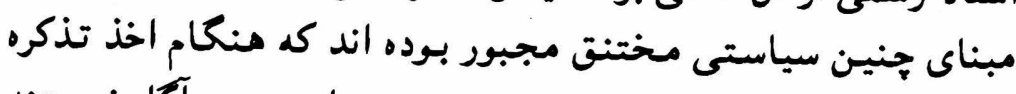

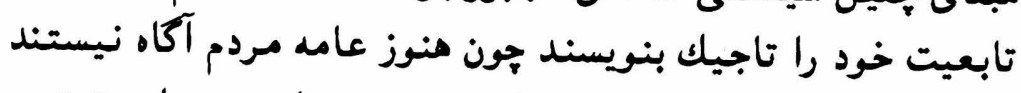

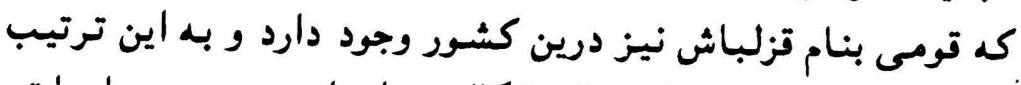

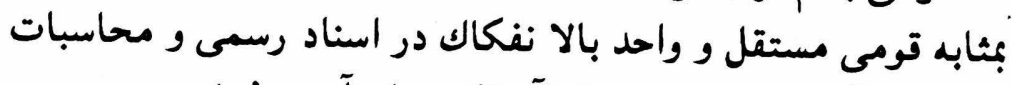

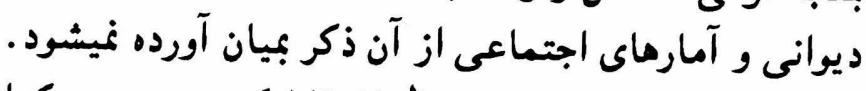

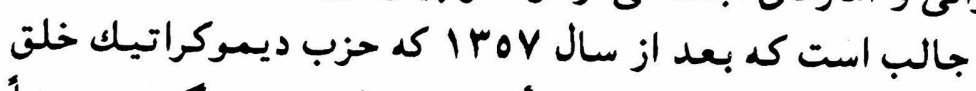
افغانستان مدعى طرح و حل مسأله ملى در كشور مى كردد و و بعضاً

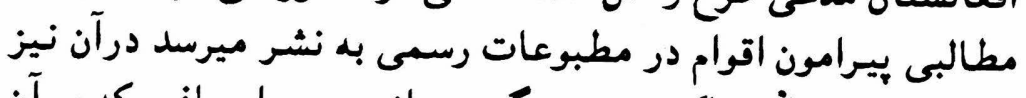

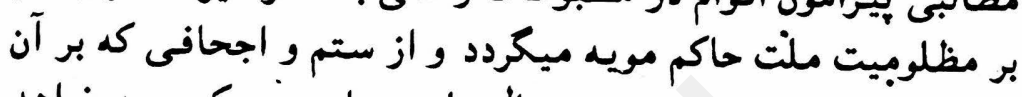

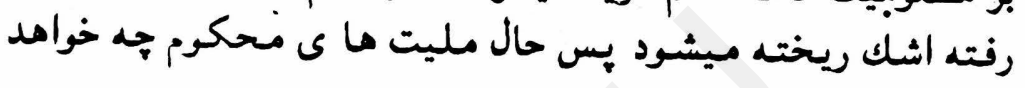
بود (1) بونها

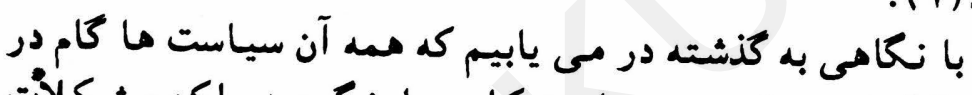

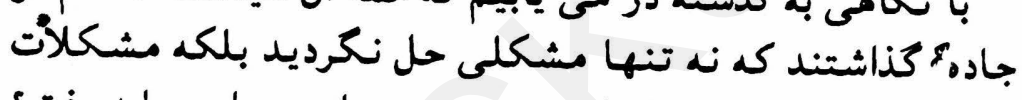

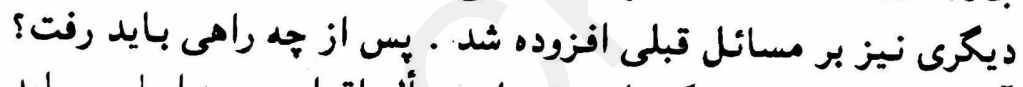

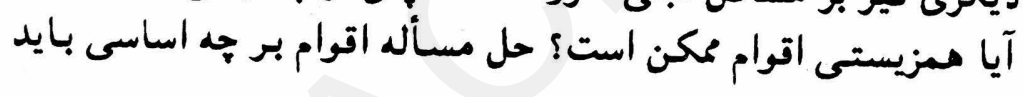

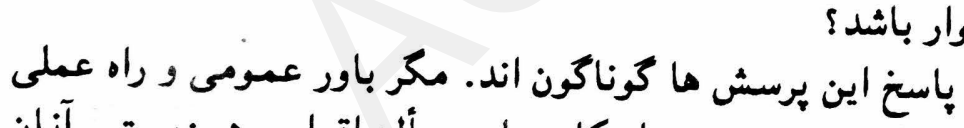

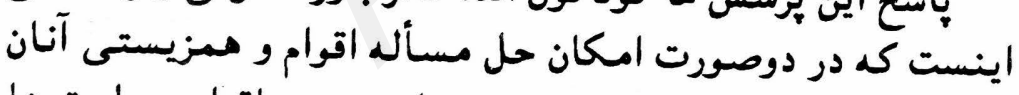

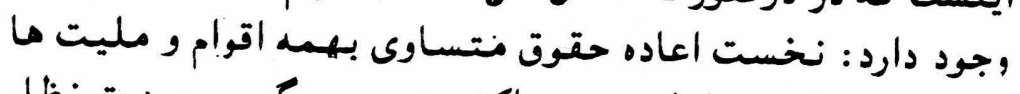

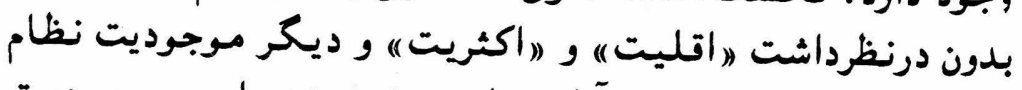

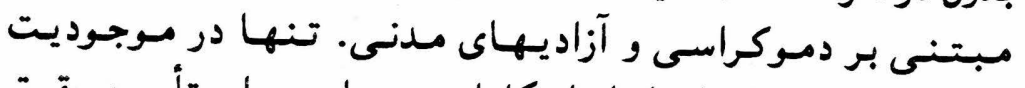

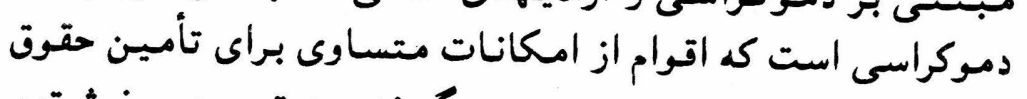

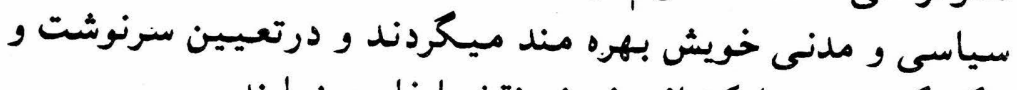
جكونكى رشد و انكشاف خويش نقش ايفاء مينمايند. *** 
طرح مسئله مليت را برخى مخالف وحدت ملى و كامى در جهت

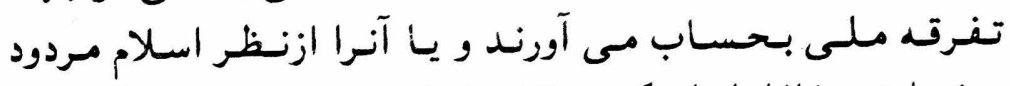

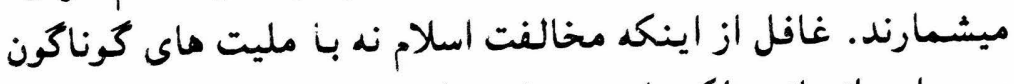

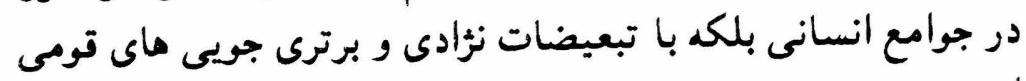
است.

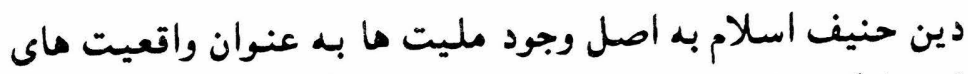

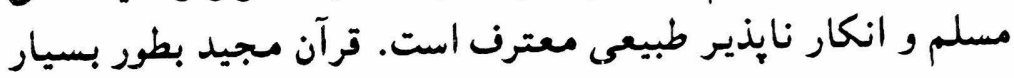

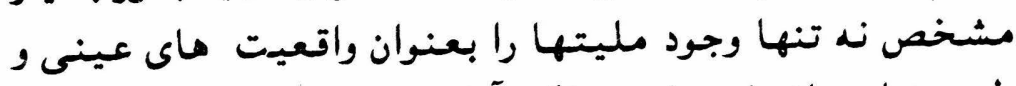

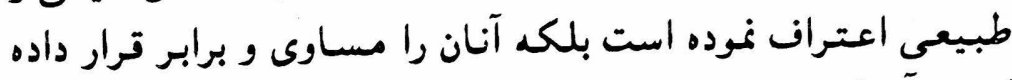

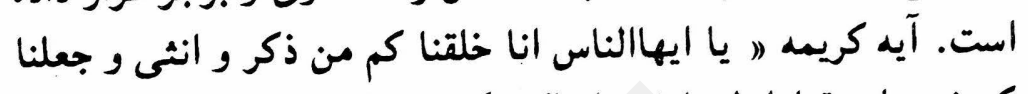
كم شعويا و قبايل لتعارفو، ان ان اكرمكم عند الله اتقاكم ) .

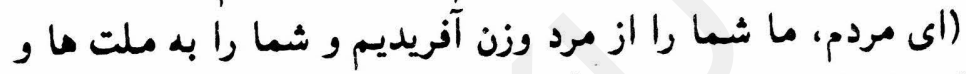

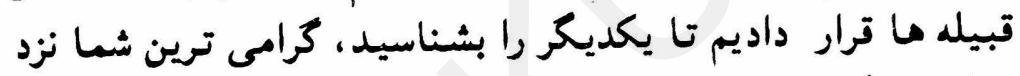

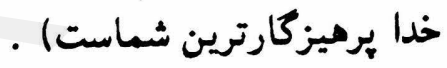

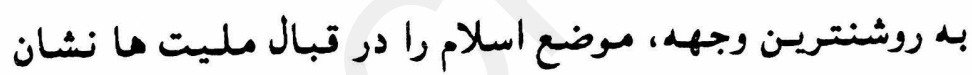

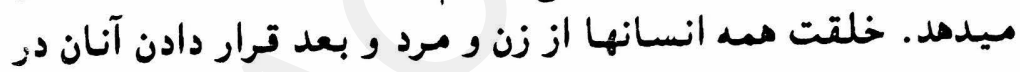

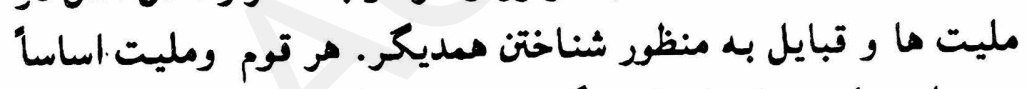

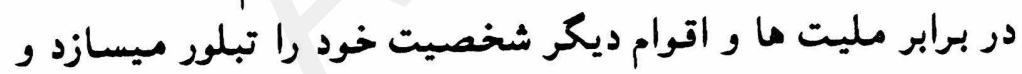

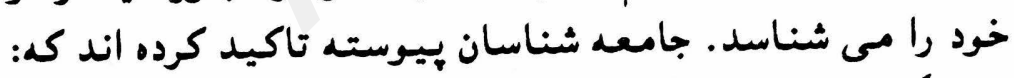

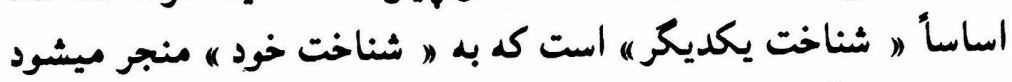

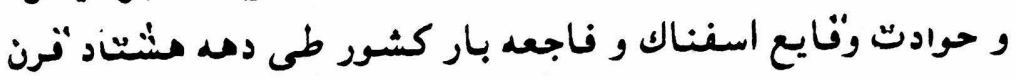

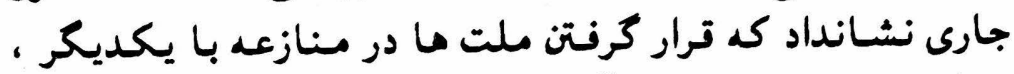

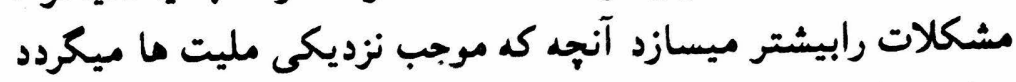

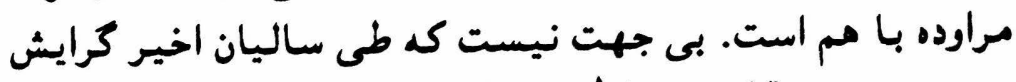

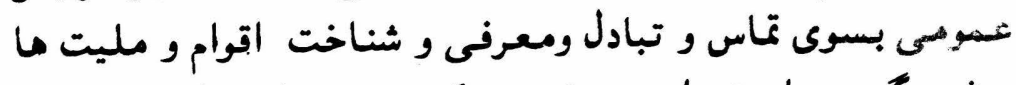

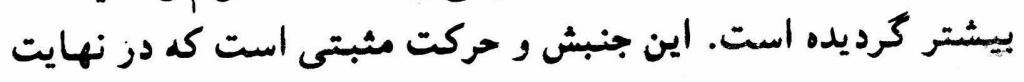


جهره اقوام و مليت ها مشخص تر و روشنتر ميكردد وخود آحاهى

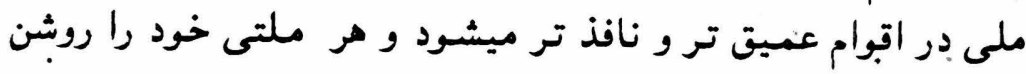
تر و مطئن تر احساس ميكند.

***

مفهوم اقليت: - مفيت

بررسى ما در مباحث آينده مريوط به قزلباشان كه خود در در شمار

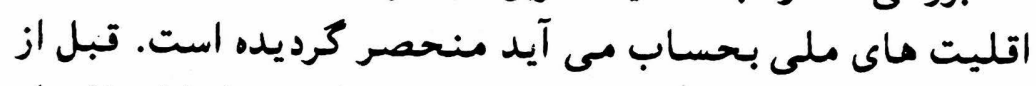

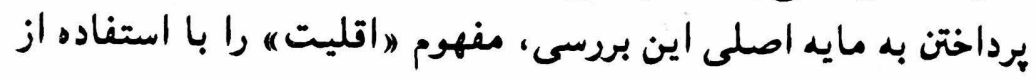

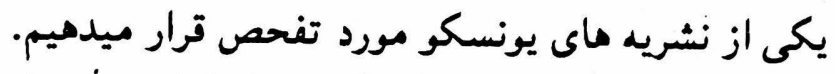

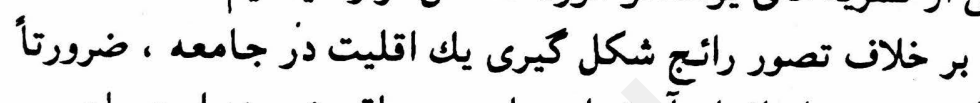

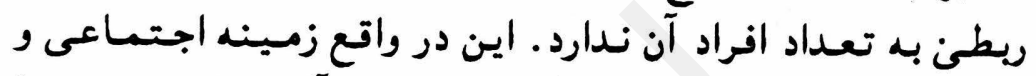

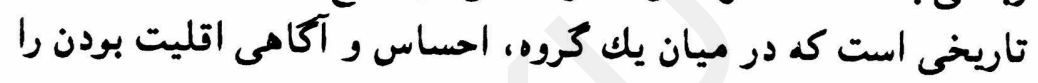

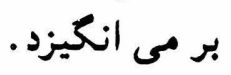

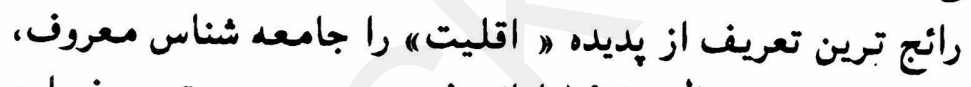

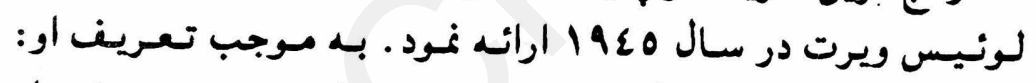

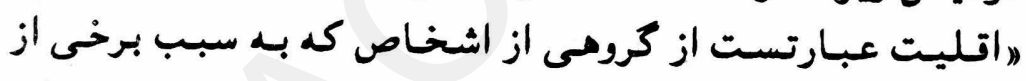

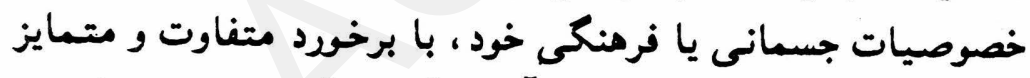

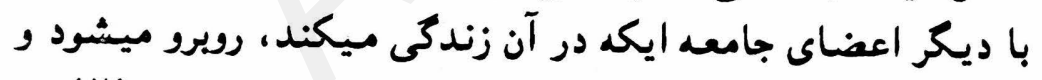

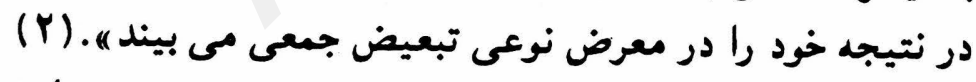

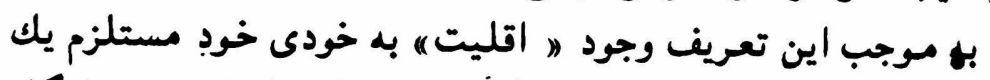

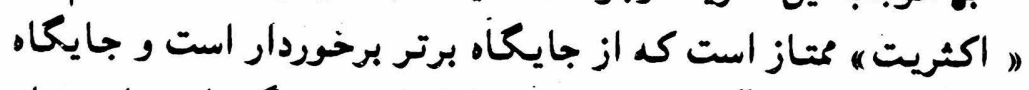

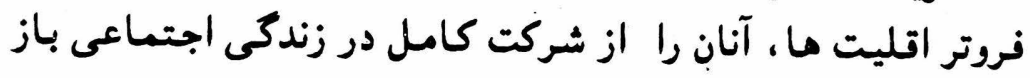

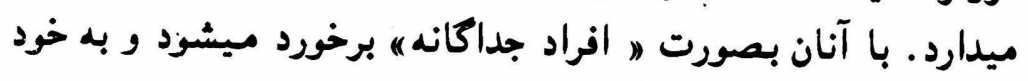
آنان نيز جنين احساسى دست ميدهد.

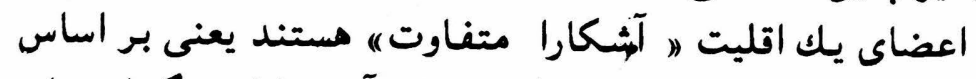

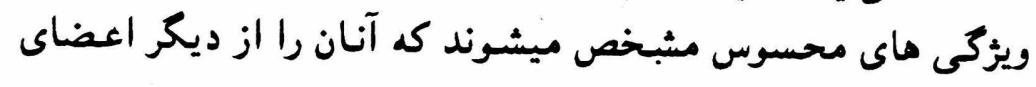


جامعه جدا ميكند. افرادى كه با آنان رفتار جداكانه ميشود و به اين

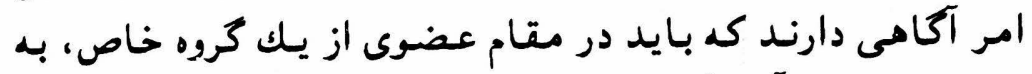

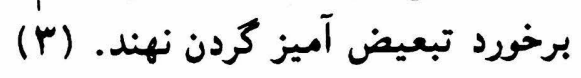

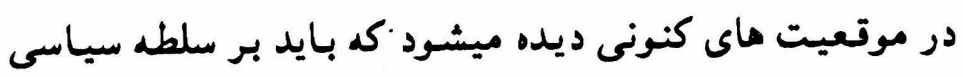

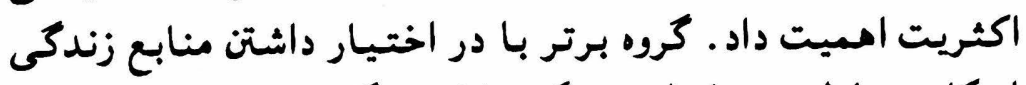

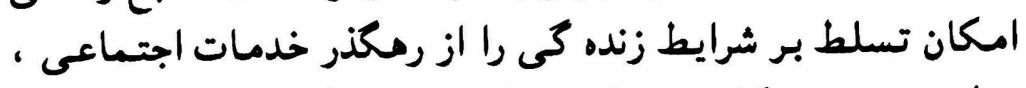

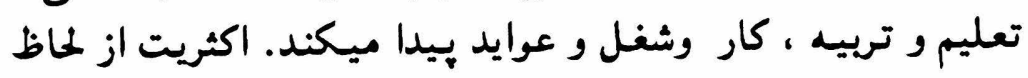

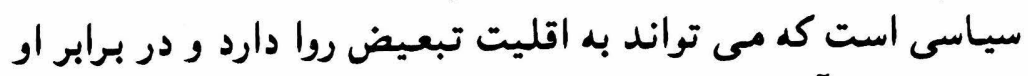

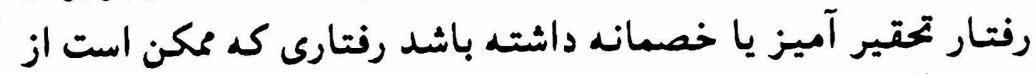

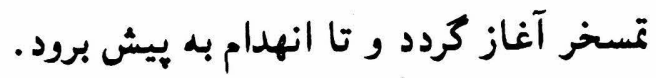

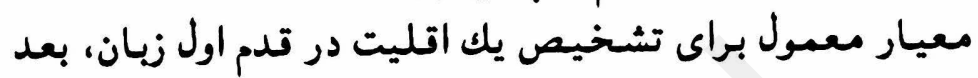

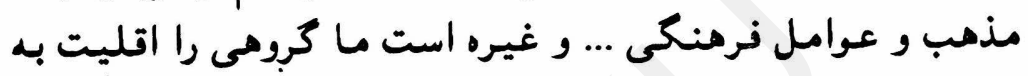

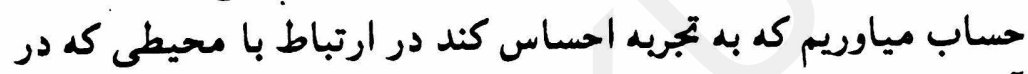

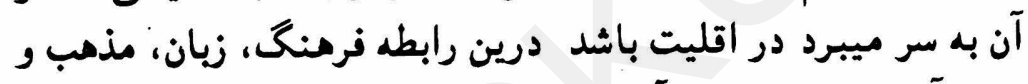
سنت آن نيزيحساب مى آيدر آيد.

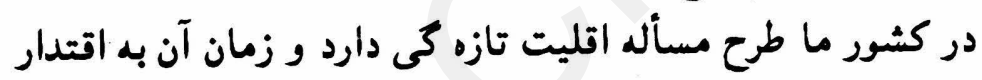

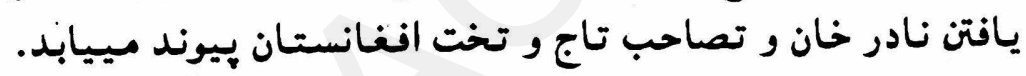

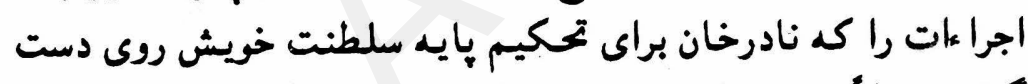

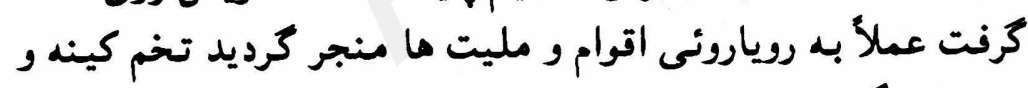

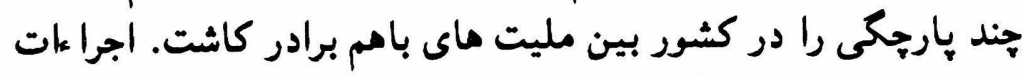

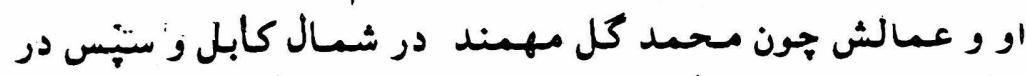

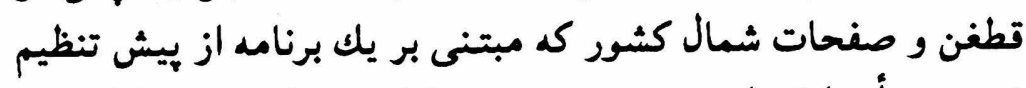

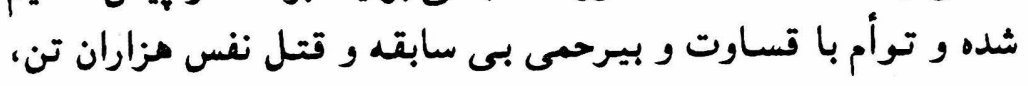

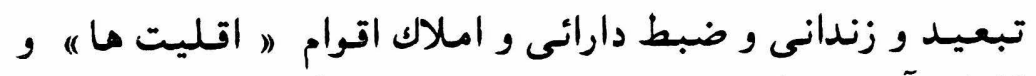

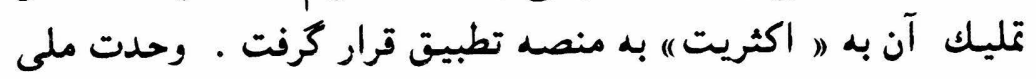

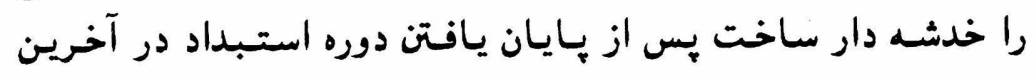


سالهاى دهد قانون اساسى ظاهراً در رابطه با زبانهاى يشتو و درى،

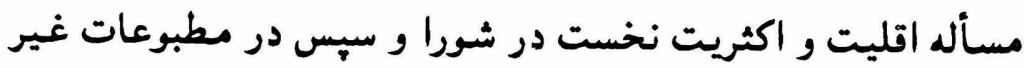
دولتى مطرح بحث قرار كرفت.

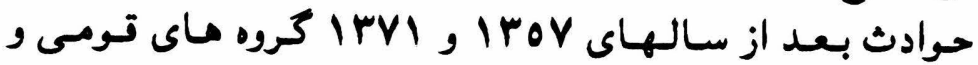

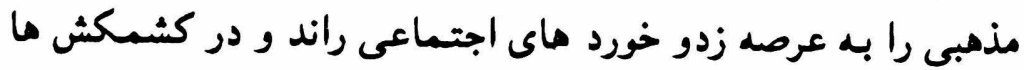

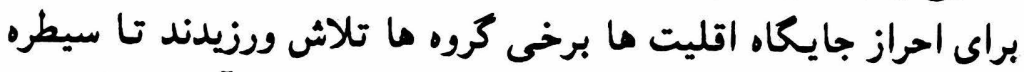

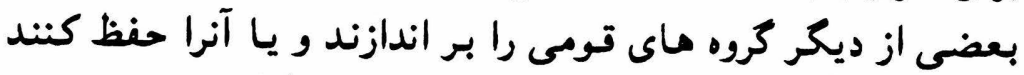

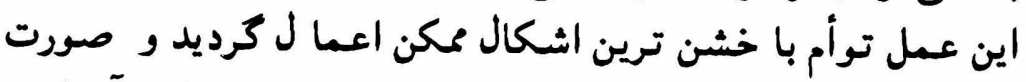

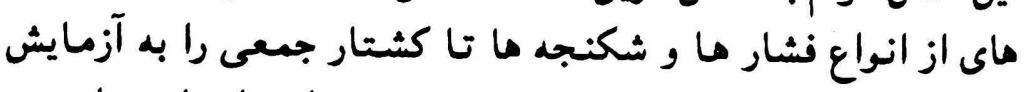

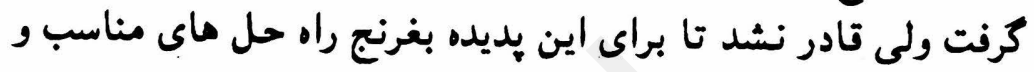
معتول رادريابد. مطالب كردآمده در اين تأليف اختصاص بـه تاريخ يكى ازين

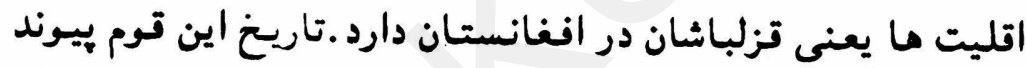

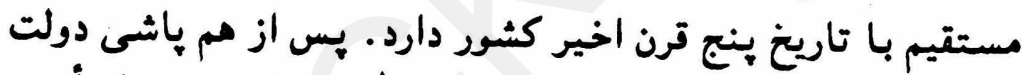

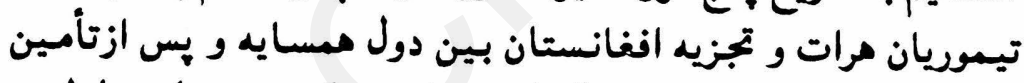

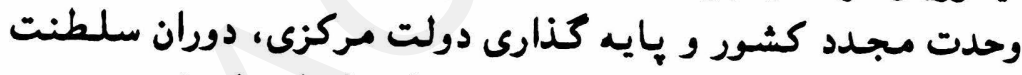

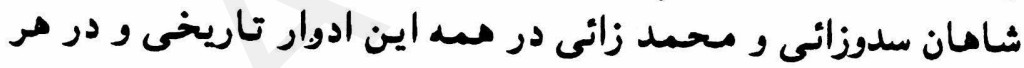

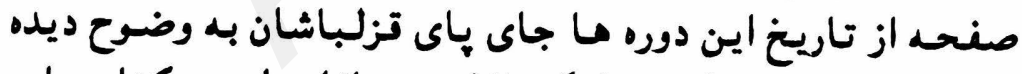

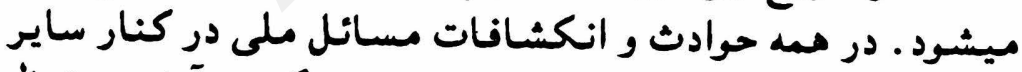

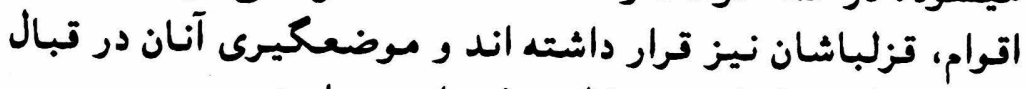

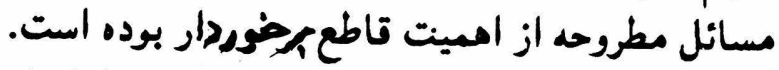

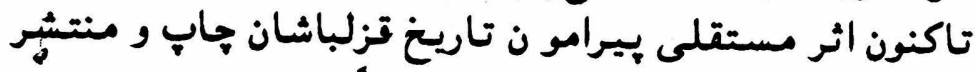

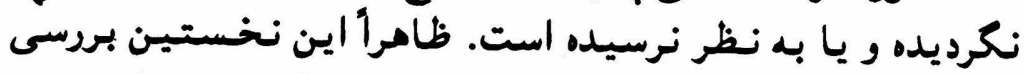

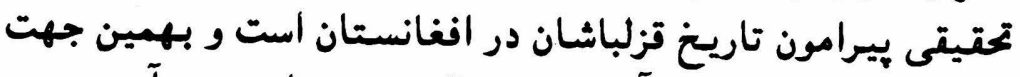

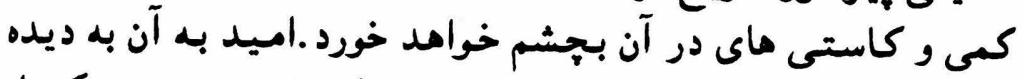

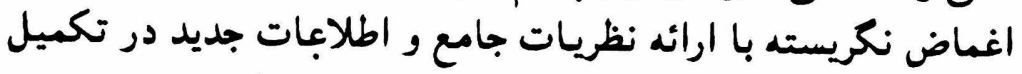
آن مساعدت نموده، بر تسويد كننده اين اوراق منت كذاريد. 


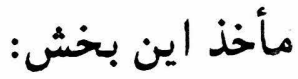

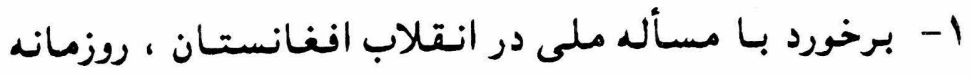

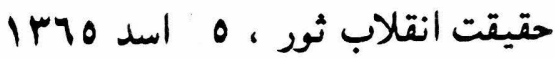

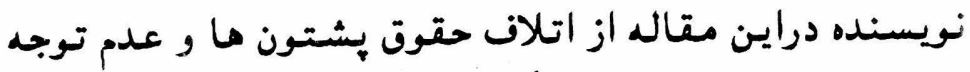

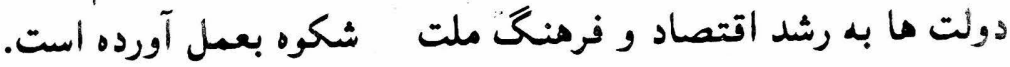

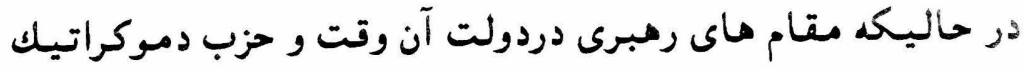

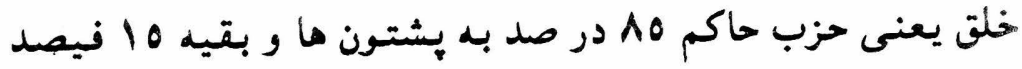

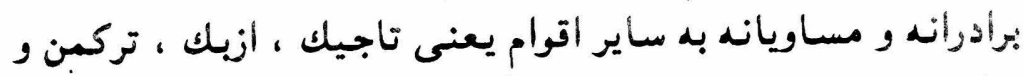

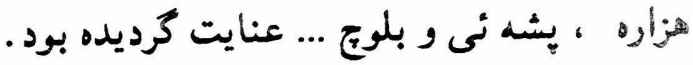

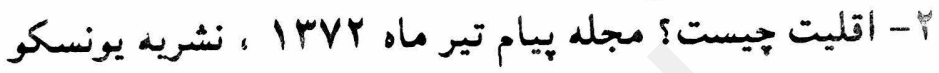
با - أحساس تفاوت، همان مجله

$\wedge$ 


\section{$-1$.}

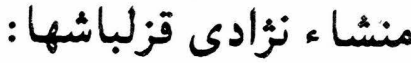

در مورد قزلباش ما كه از قرن بأنزده ميلادى در افغانستان

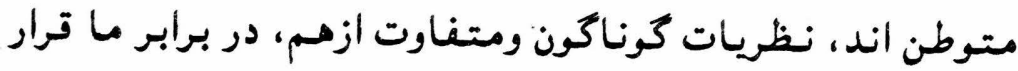

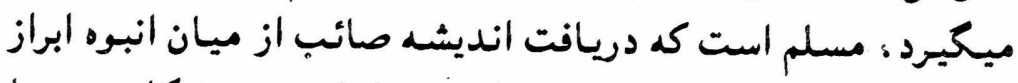

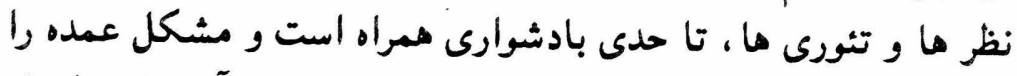

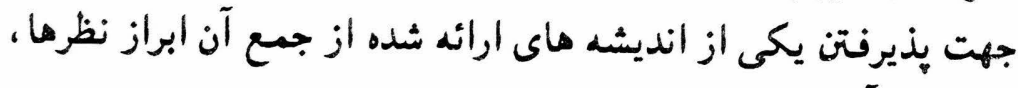
بميان مى آورد.

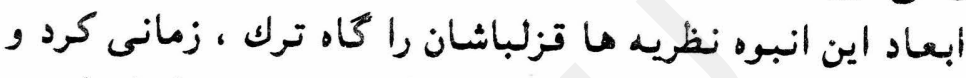

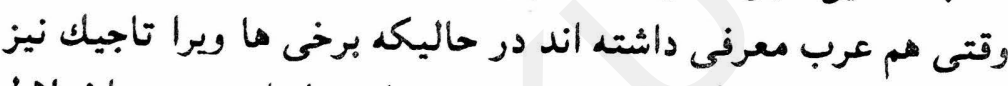

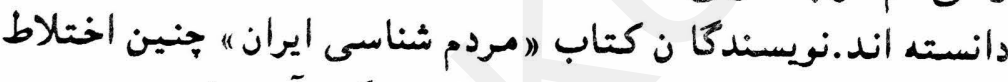

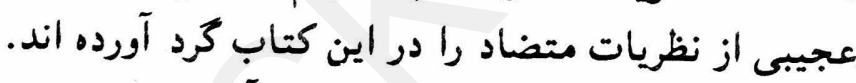

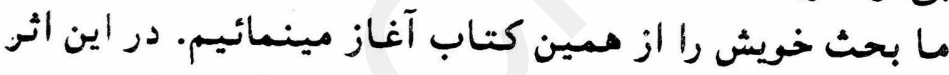

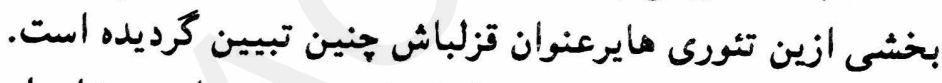

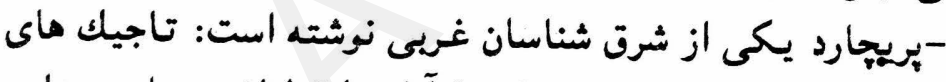

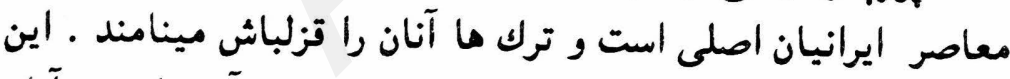

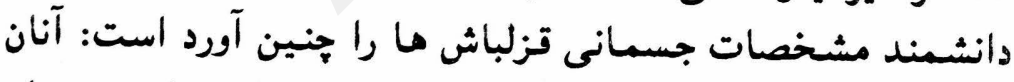

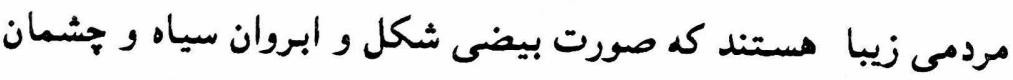
مشكى دارند.

- ايرى، ماكى مستشرت دارند ديكر، قزلباش ما را يكى از قبايل باديه نشين ترك ميداند.

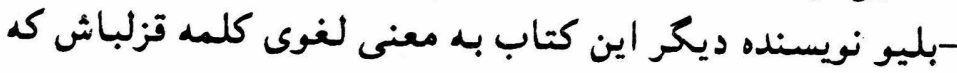

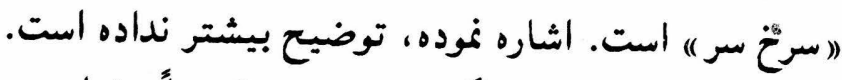

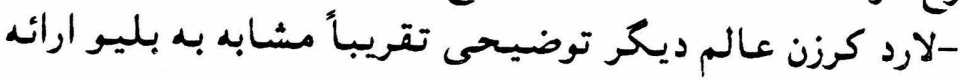


نموده، قزلباش را شامل هنت قبيله (" سرخ سر ) ميداند و توضيح

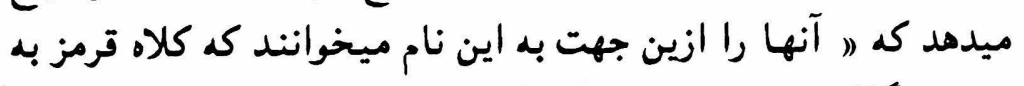
سر مى كذاشتتند. ).

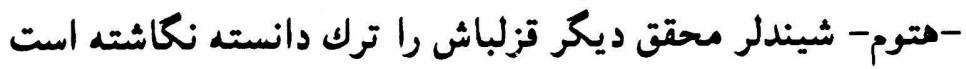

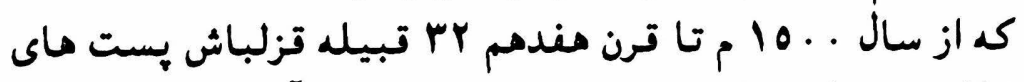

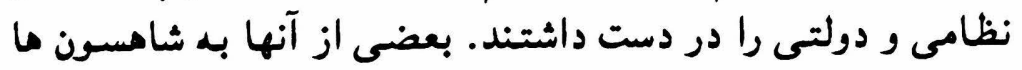

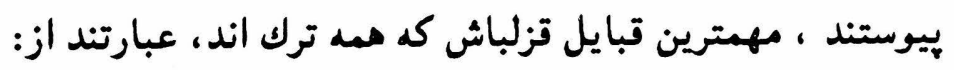

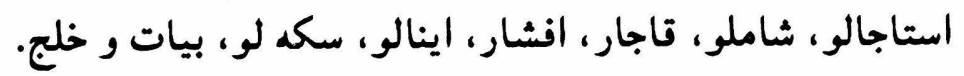

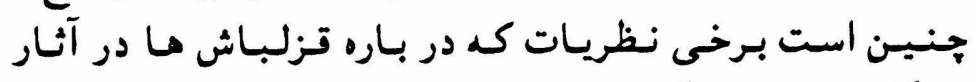

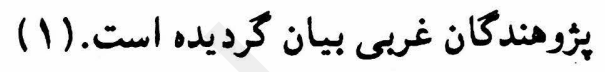

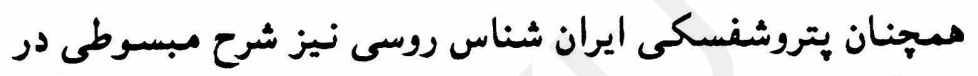

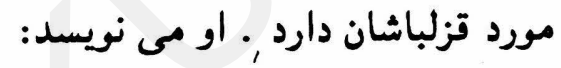

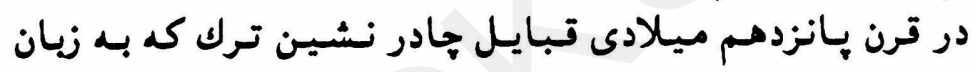

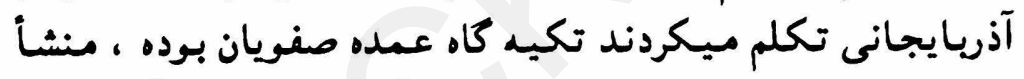

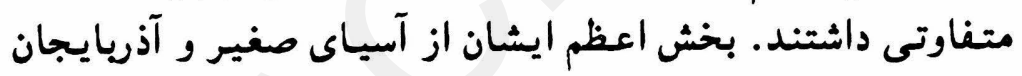

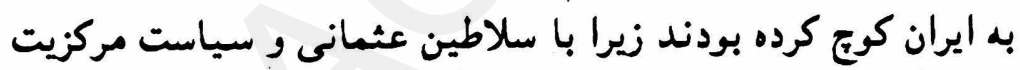

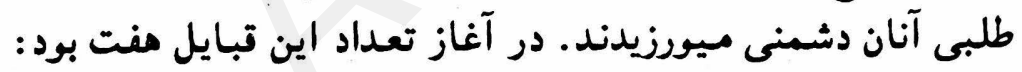

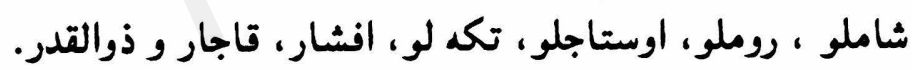

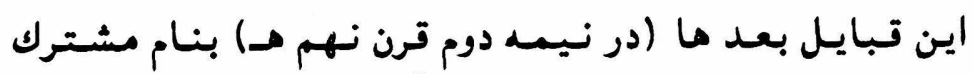

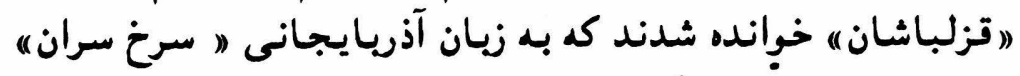

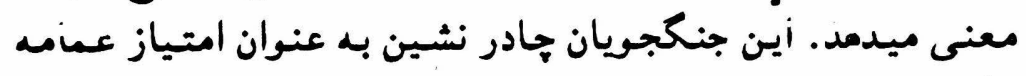

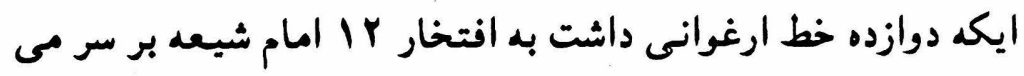

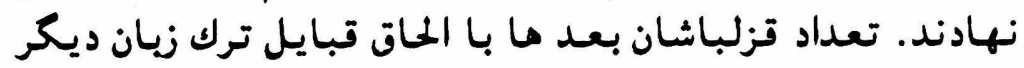

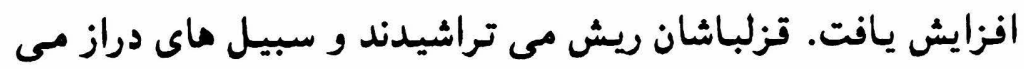

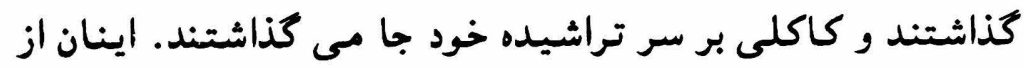

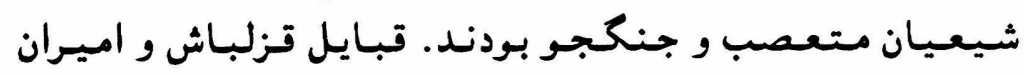


جادرنشين فئودال ايشـان از لحاظ روحانى و سياسى مريوط و تابع

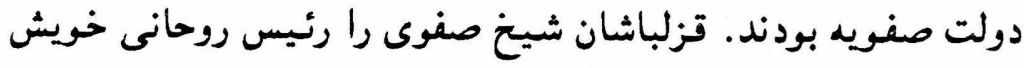

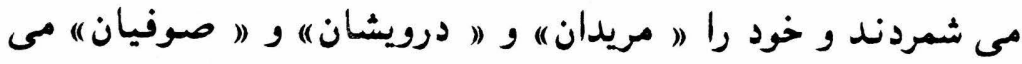

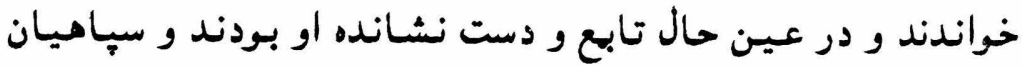

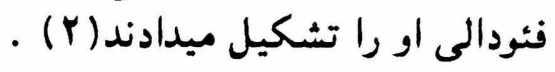

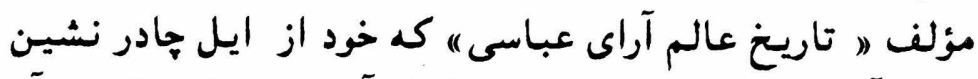

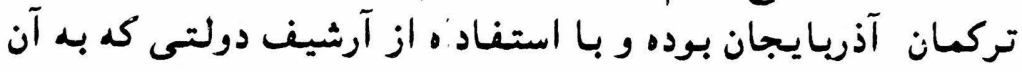

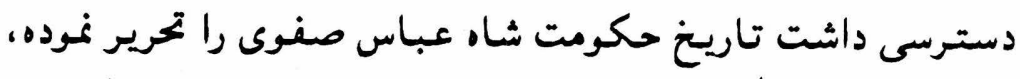

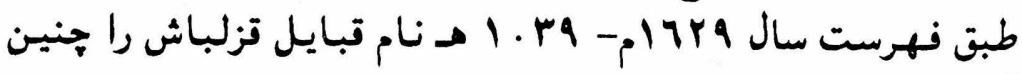

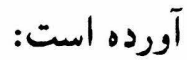

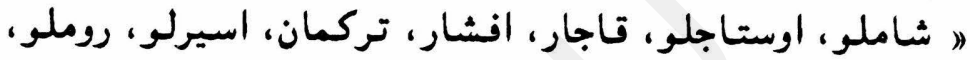

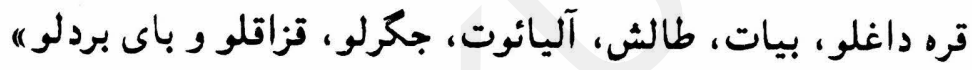

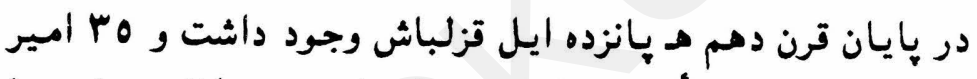

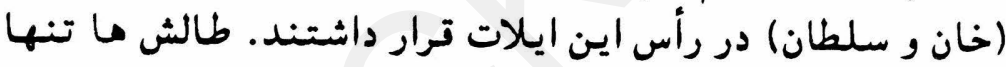

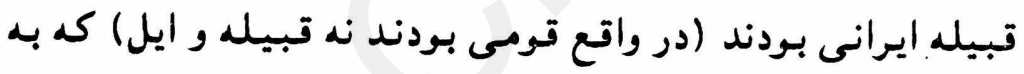

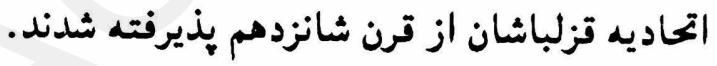

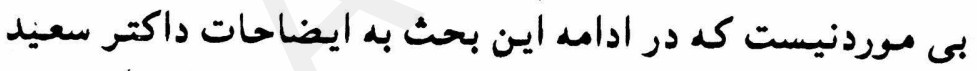

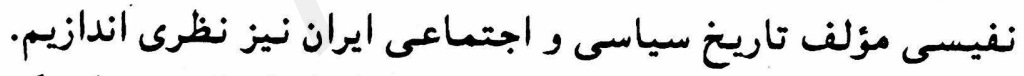

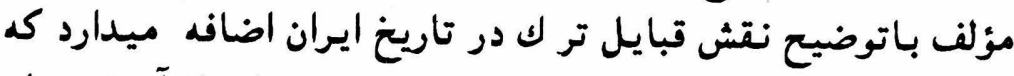

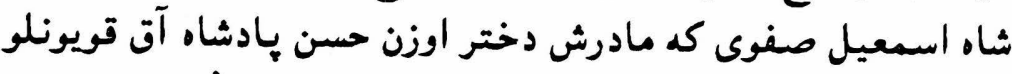

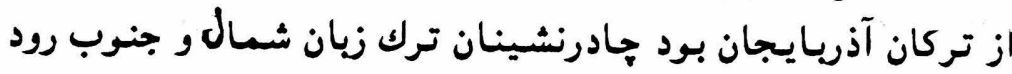

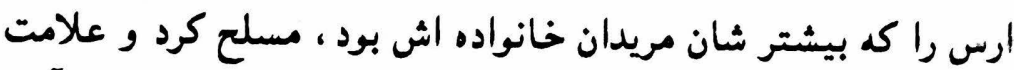

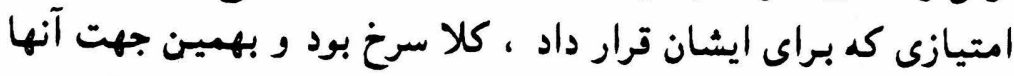

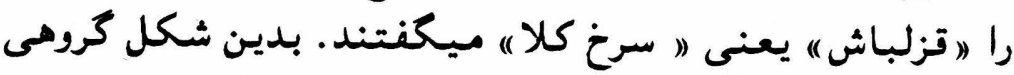

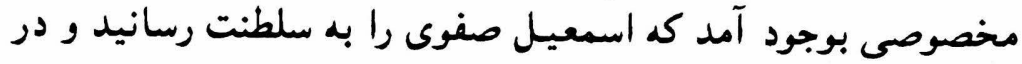

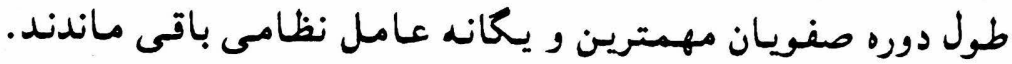


فرماندهان اين گروه مخصوص نيز از خود آنان بودند و به كسانى از

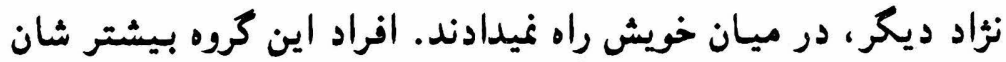

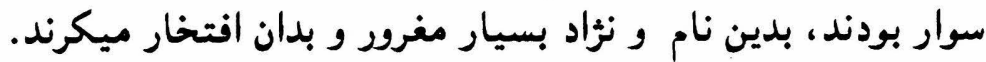

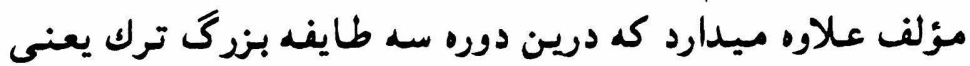

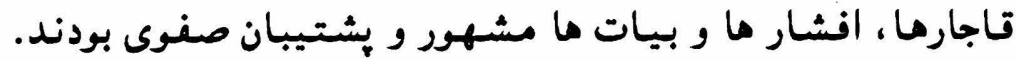
طوايف كوجكتر را كه كتر بودند صفويه بدودسته تقسيبم كردند.

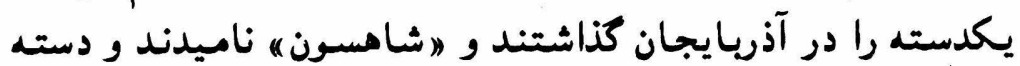

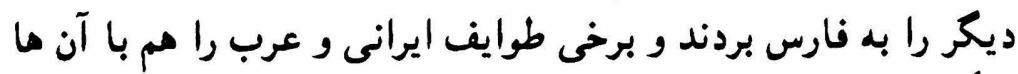

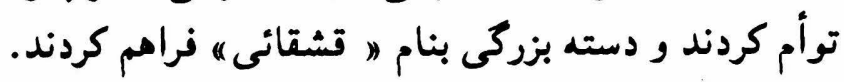

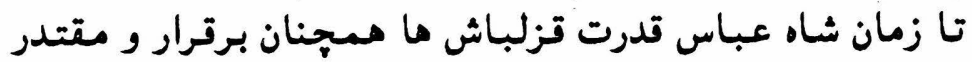

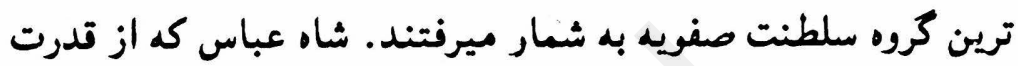

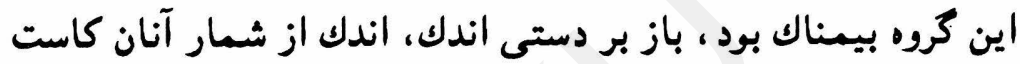

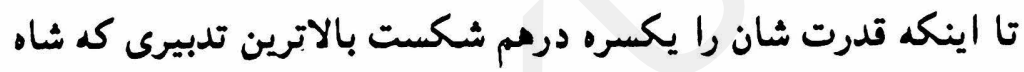

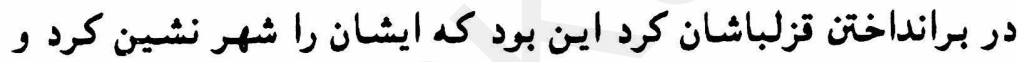

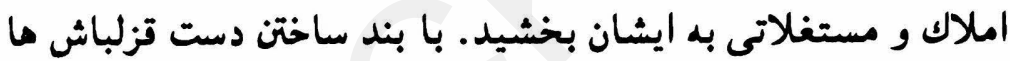

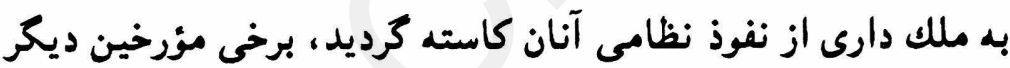

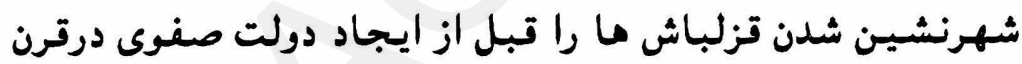

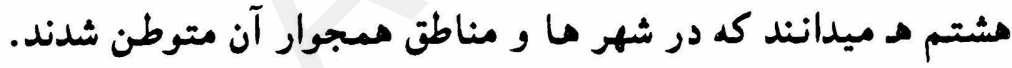

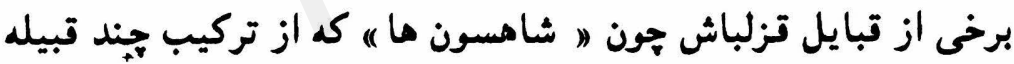

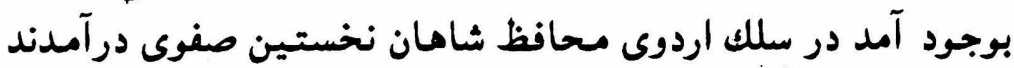

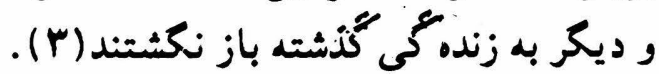

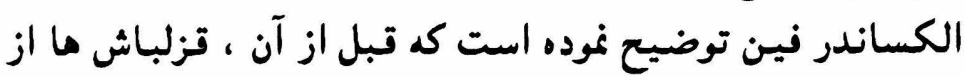

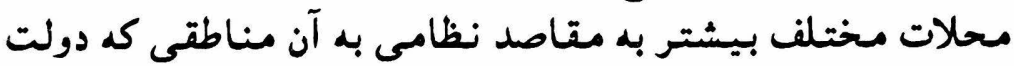

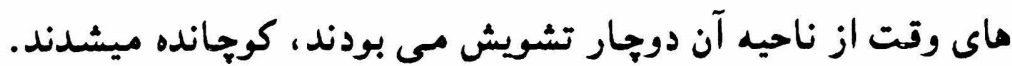

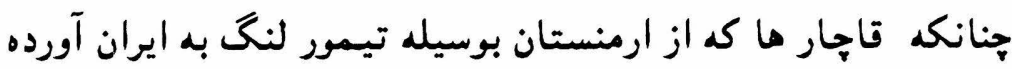

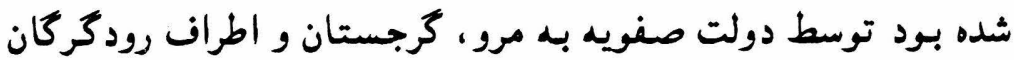


يراكنده و سكونت داده شدند.

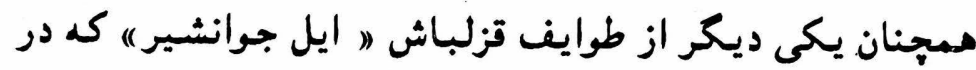

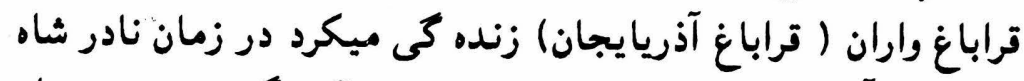

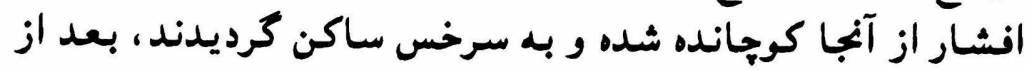

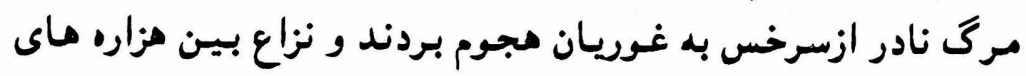

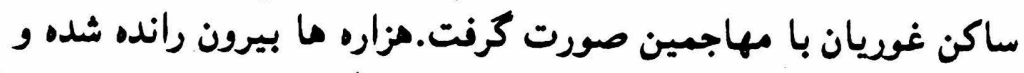

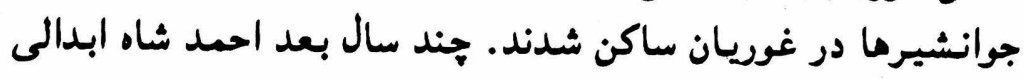

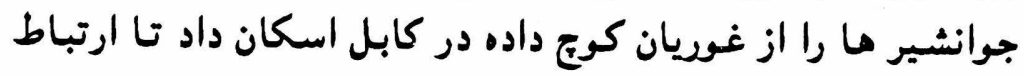

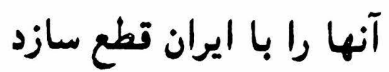

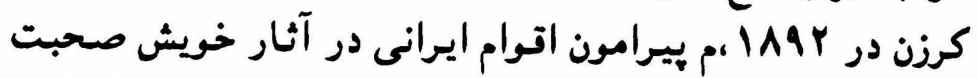

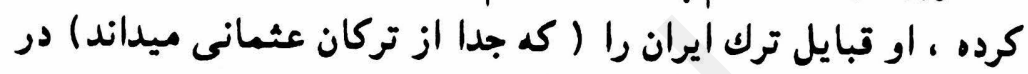

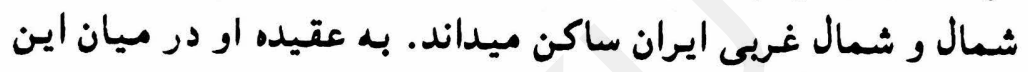

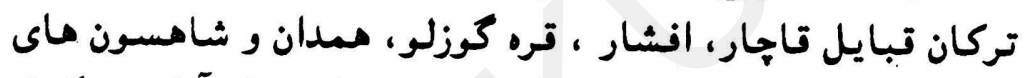

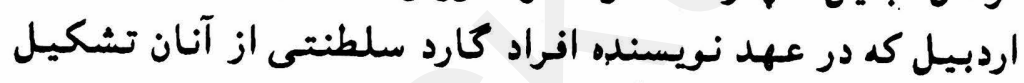

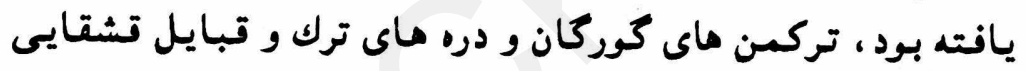

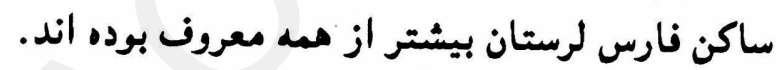

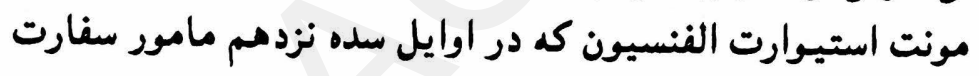

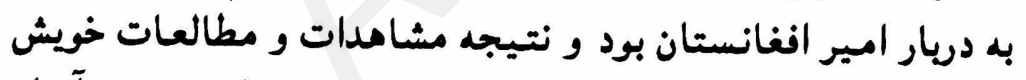

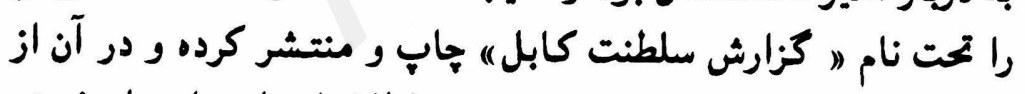

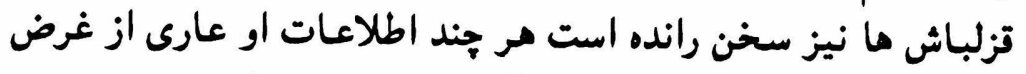

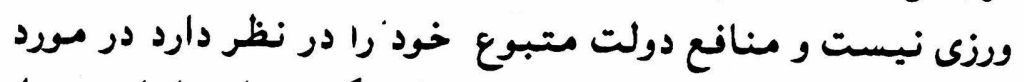

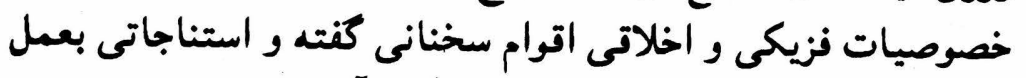

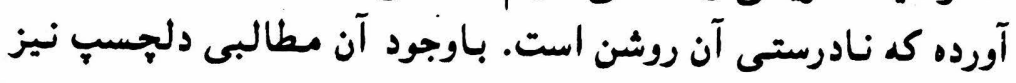

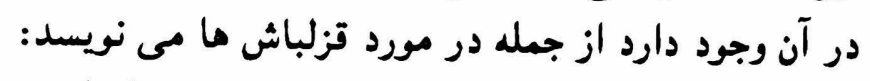

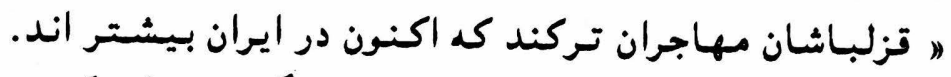

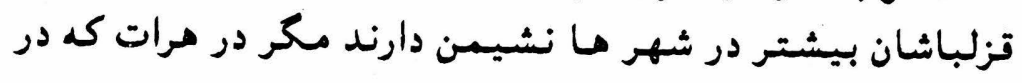




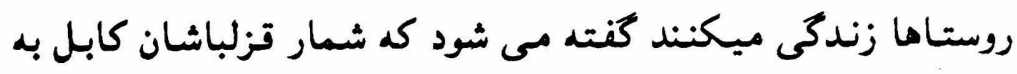

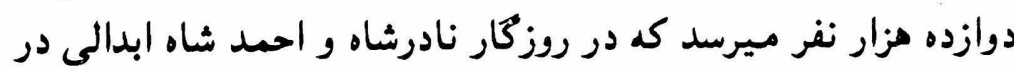

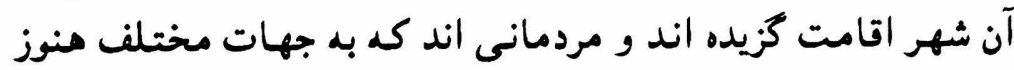

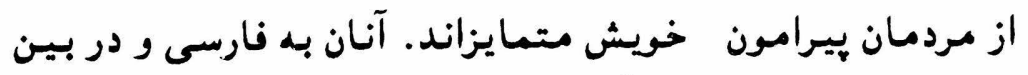

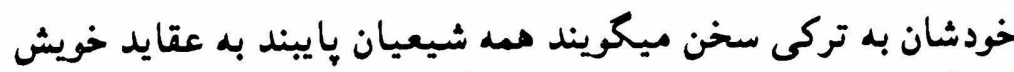
اند آنان خصائل معنوعان ايرانى شان ران ران دارند.

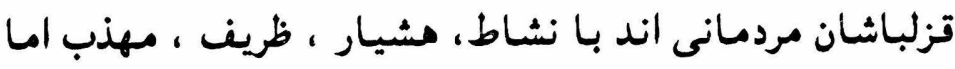

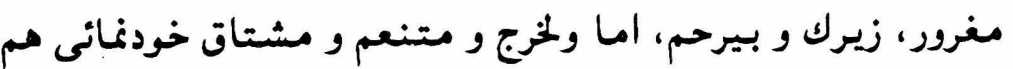

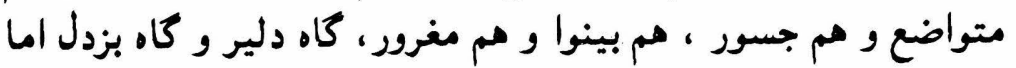

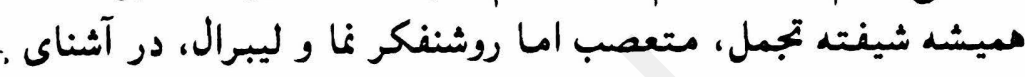

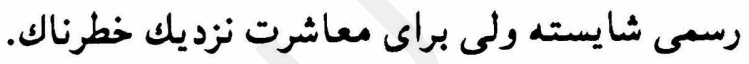

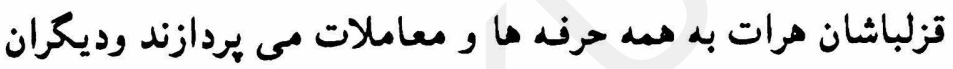

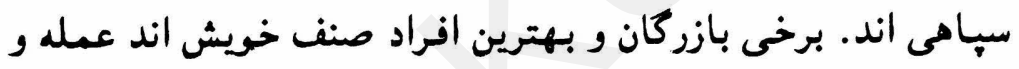

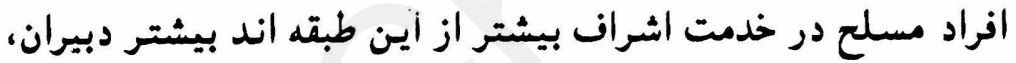

حسابداران و كارمندان ديكر قزلباش اندان اندي

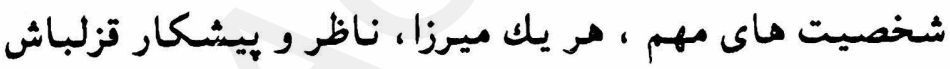

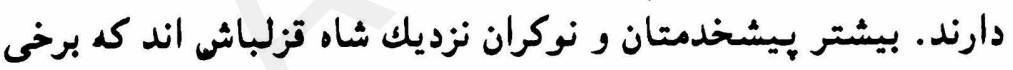

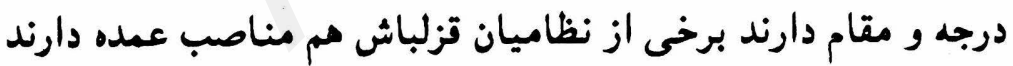

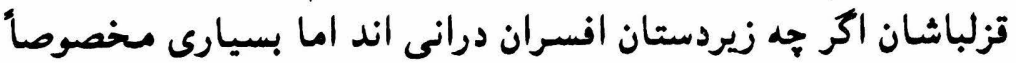

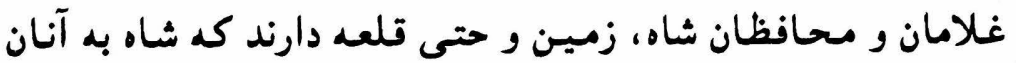

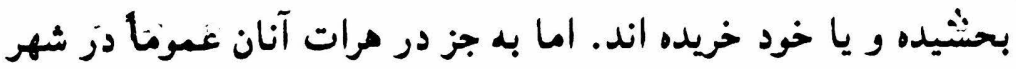

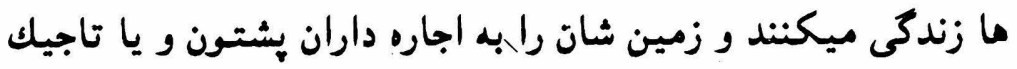

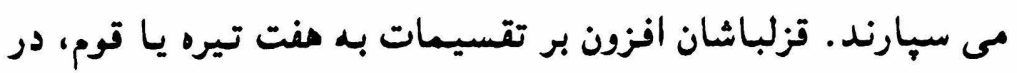

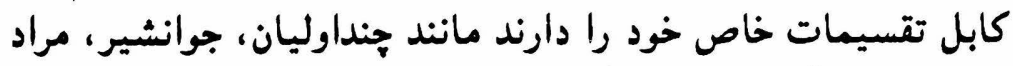

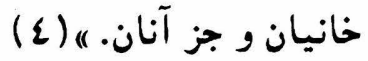

$1 \varepsilon$ 


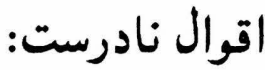

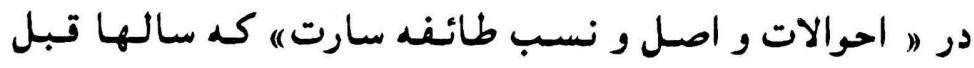

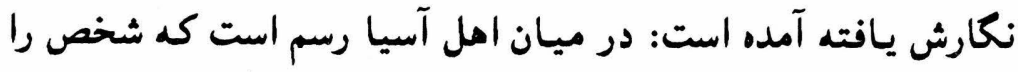

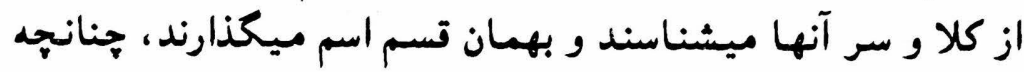

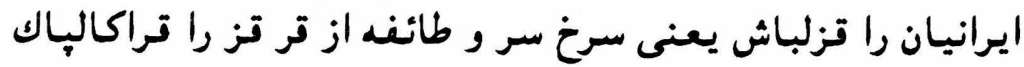

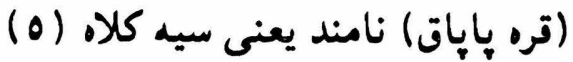

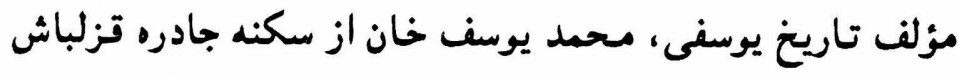

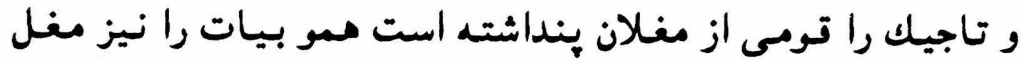
ميشسارد و ميكويد كه از بياوت كرفتله شده كه شاخه از اقوام مغل

است. (7)

در صحت تول مؤلف تاريخ يوسفى نكارنده مقاله فوق كه با او

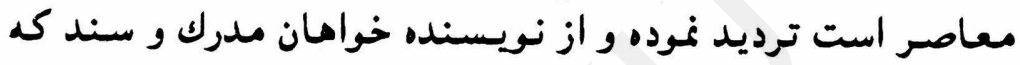

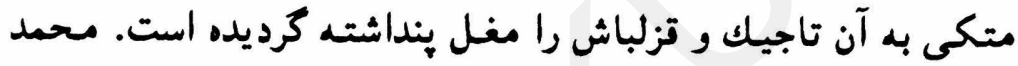

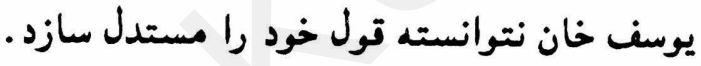

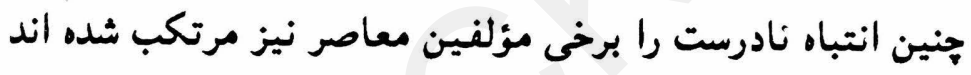

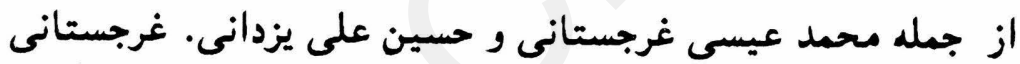

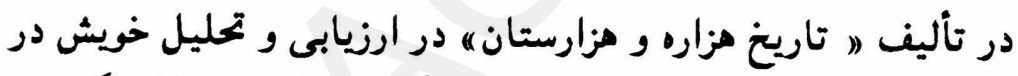

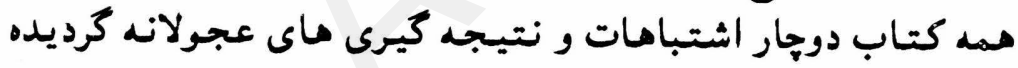

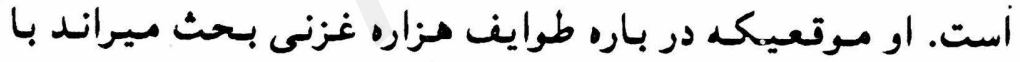

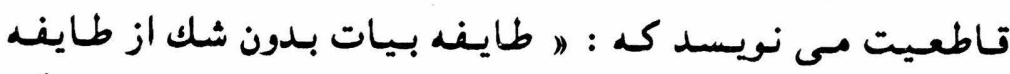

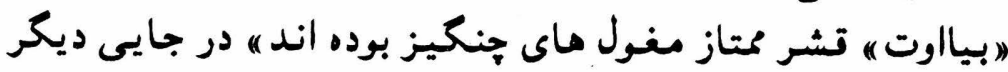

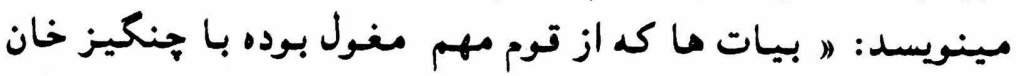
آمدند....

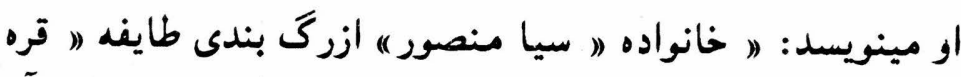

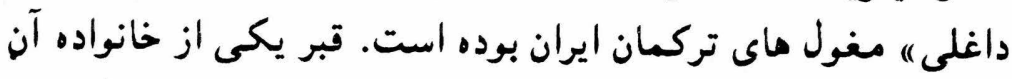

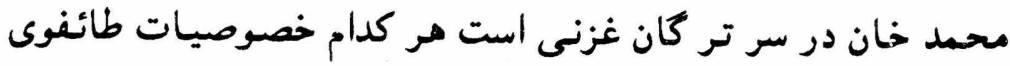


خود را حفظ كرده ، شاخه ماى ملت هزاره را تشكيل ميدهد، مشلاً

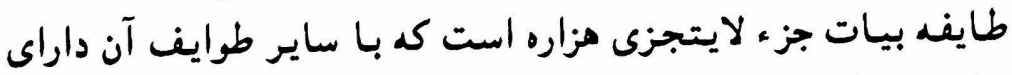

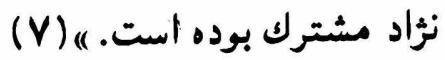

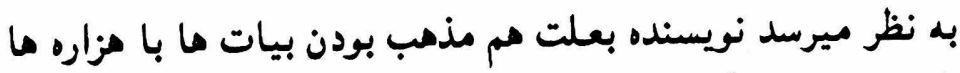

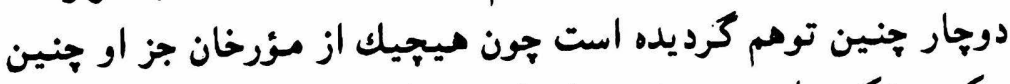

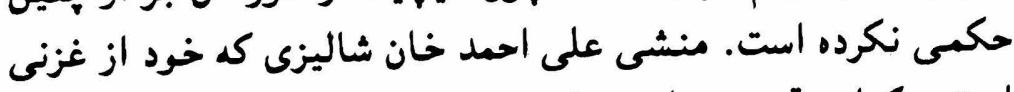

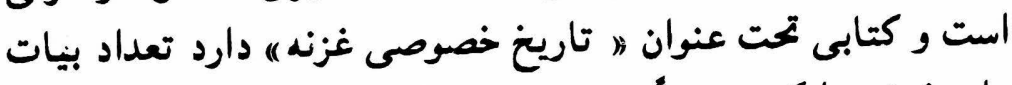

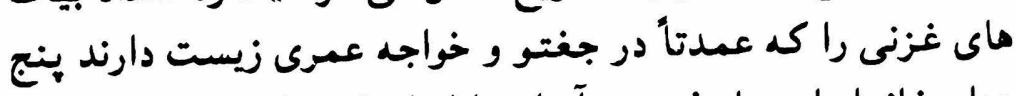

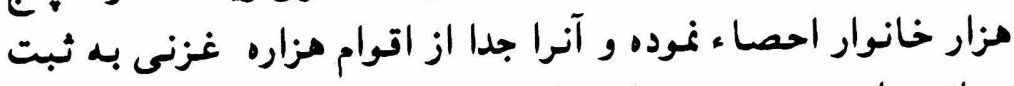

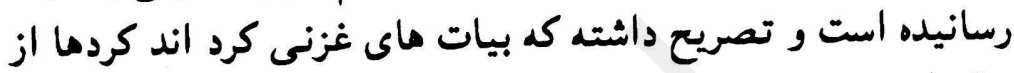

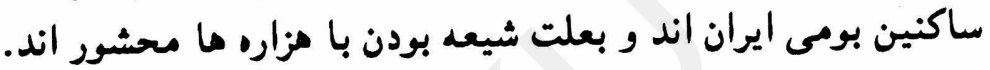

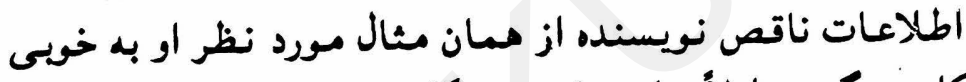

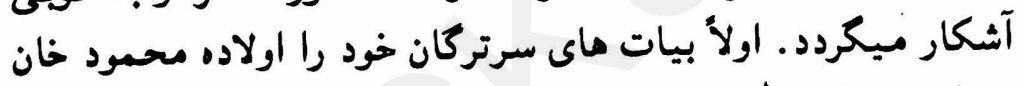

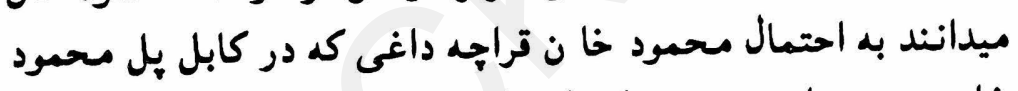

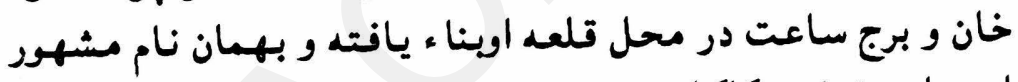

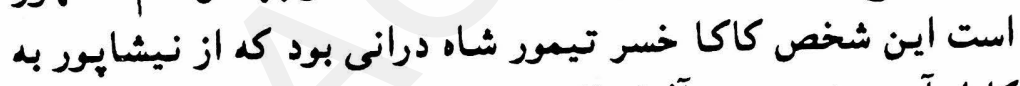

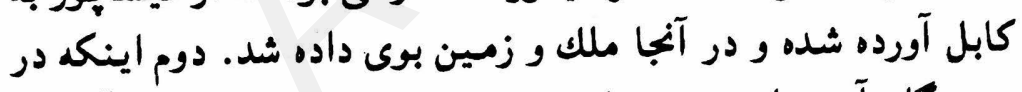

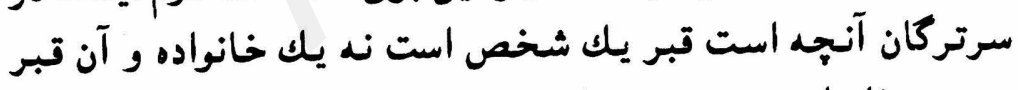
محمود خان است نه محمد خان.

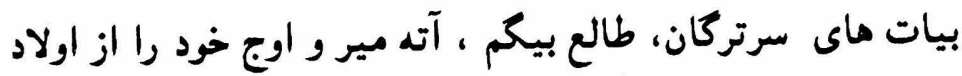

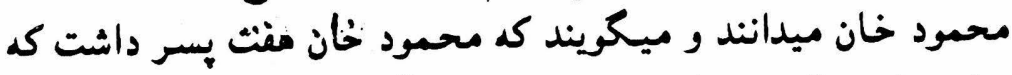

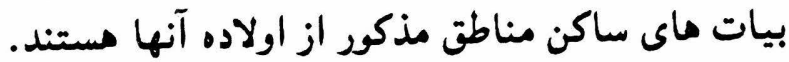

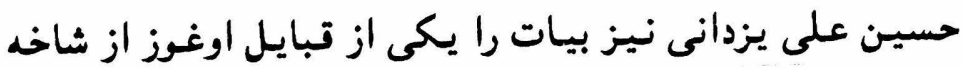

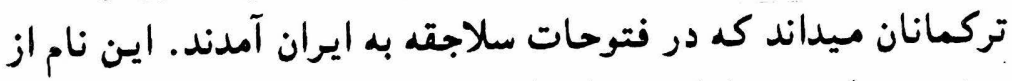

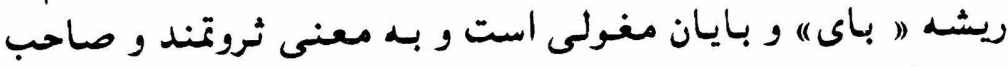
نعمت است (A). 


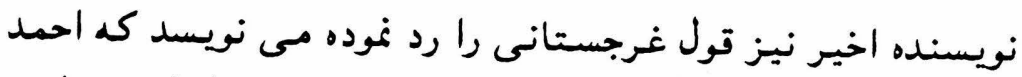

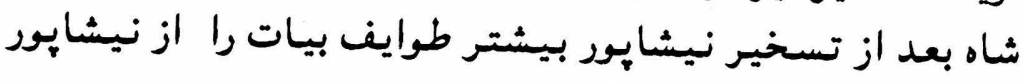

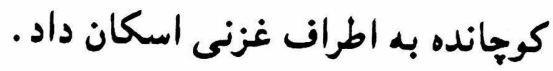

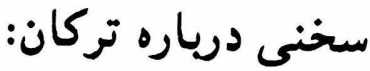

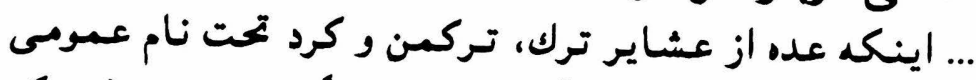

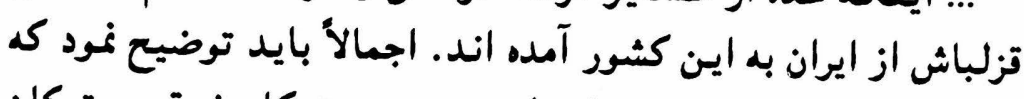

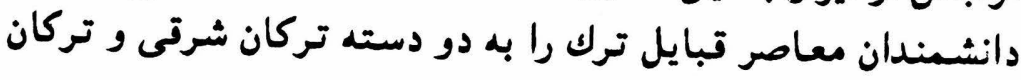

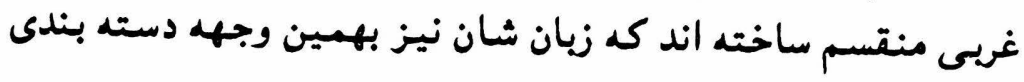
شده است.

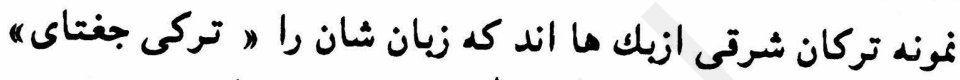

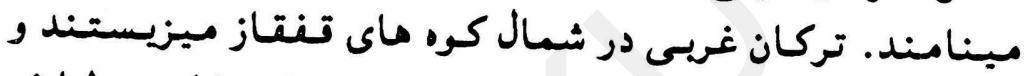

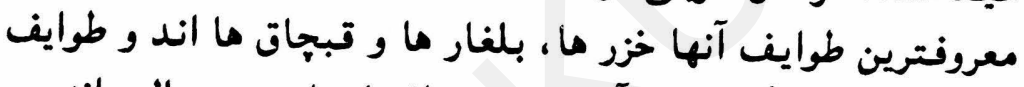

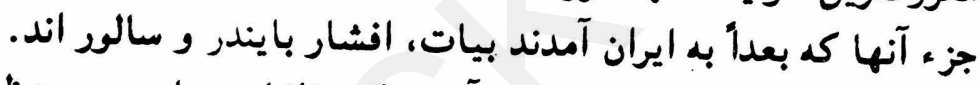

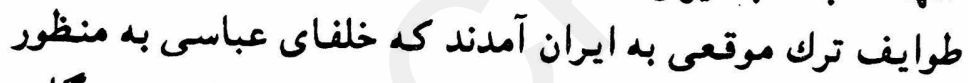

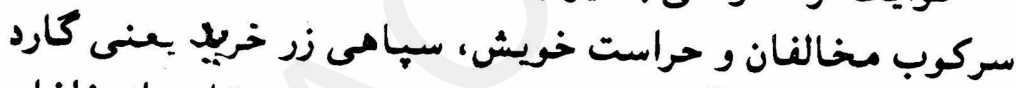

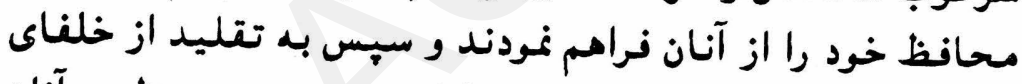

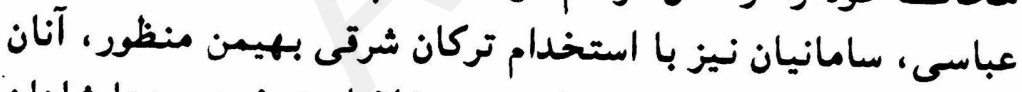

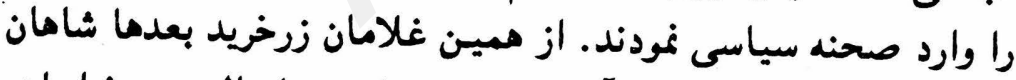

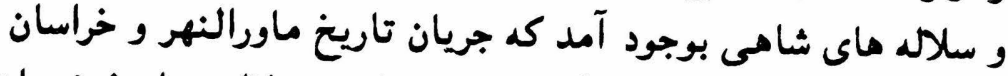

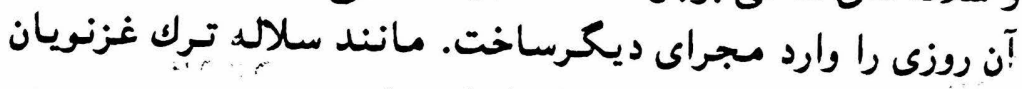

$$
\text { سلجوقيان، خوارزمشاهيان، قراختائيان و غيرهان... }
$$

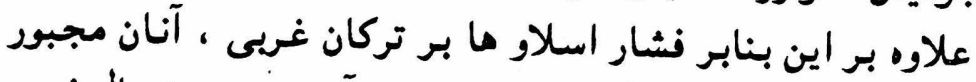

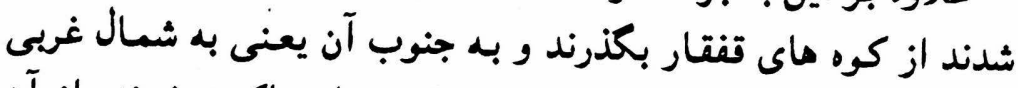

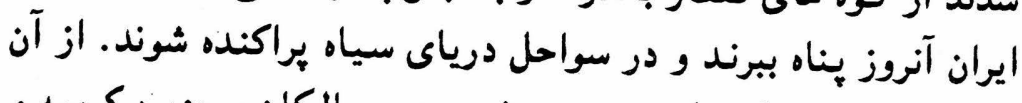

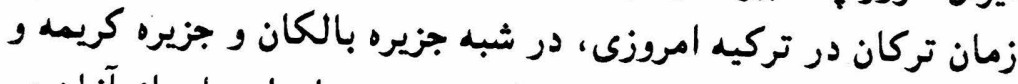

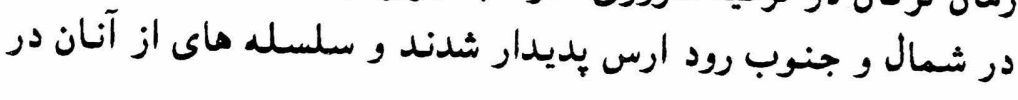




\section{اين نواحى به يادشاهى رسيدند.}

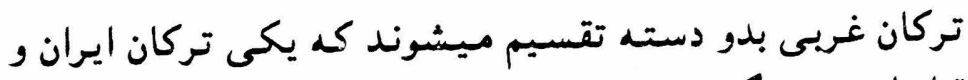

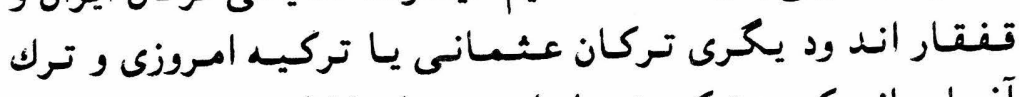

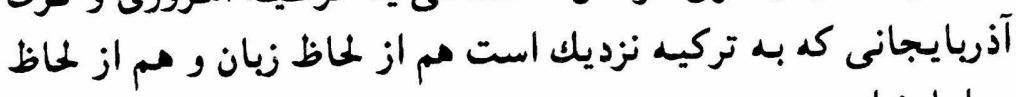

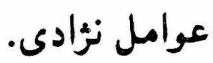

كر نتيجه فشار اسلاو ما برخى ازتركان به شام رفتند كه در ميان

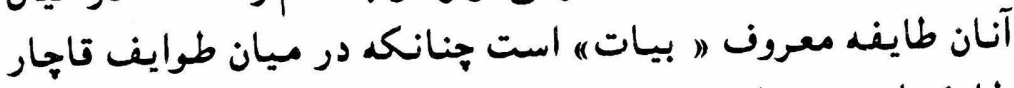

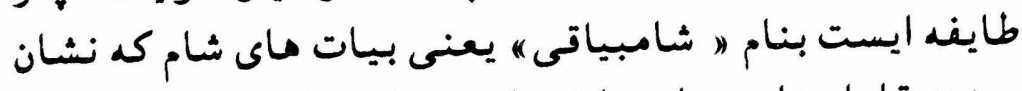

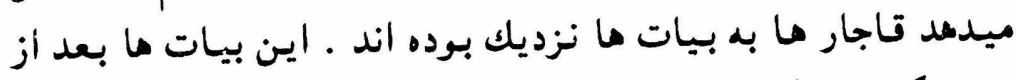

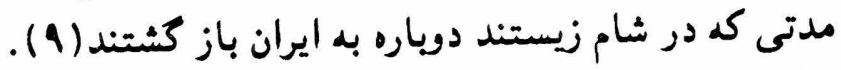

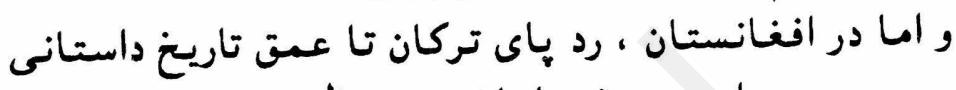

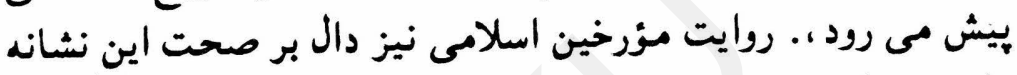

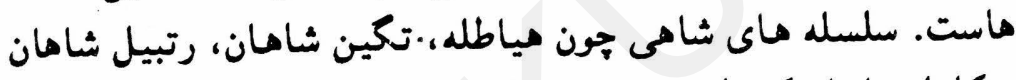

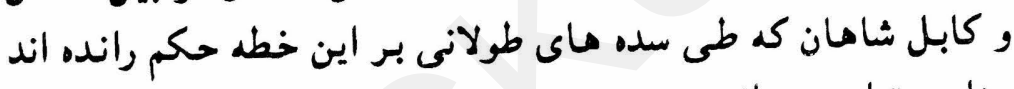
عناصر ترك بوده اند.

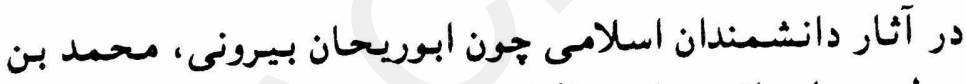

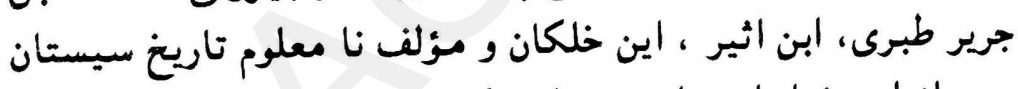

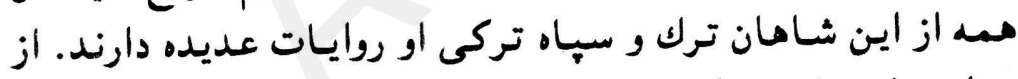

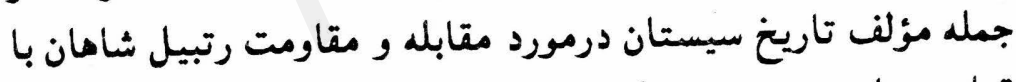

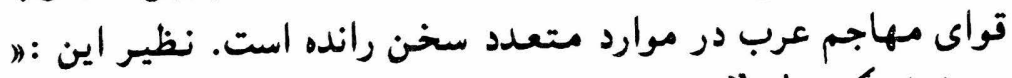

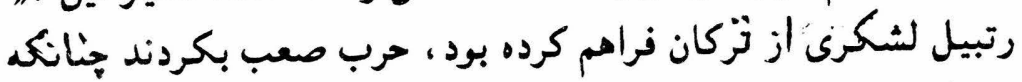

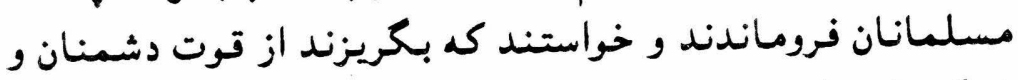

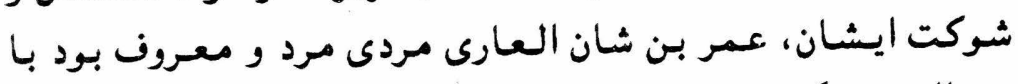

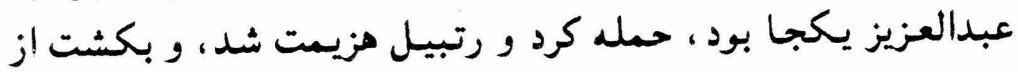
تركان بسيار و هزيمت كردند... ( • 11).

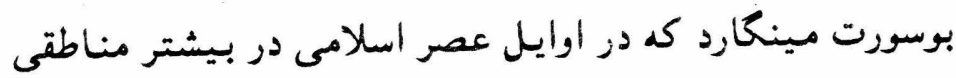




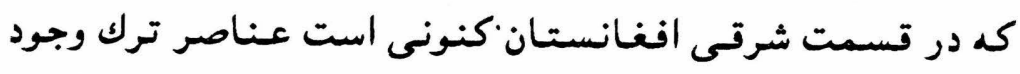

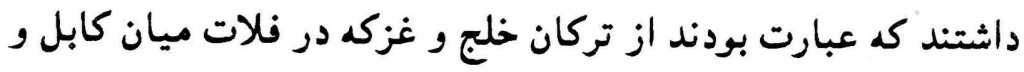

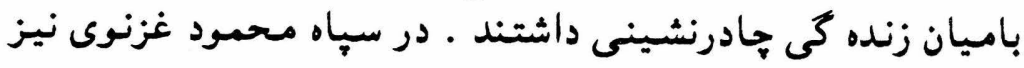

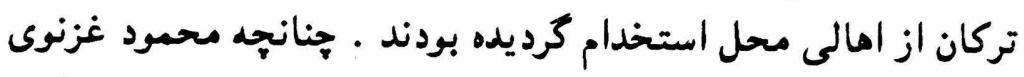

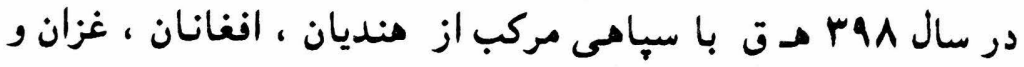

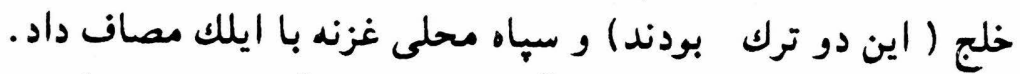

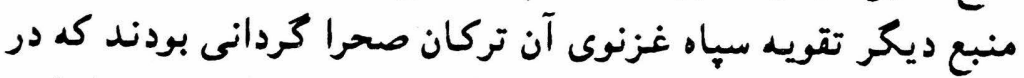

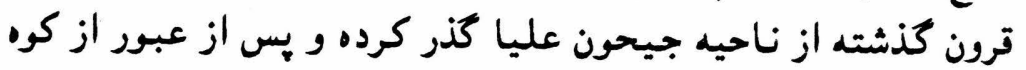
هاى مندوكش در نواحى شرقى افغانستان اسكان يافته بودند. (11)

\section{نتيجه بحث:}

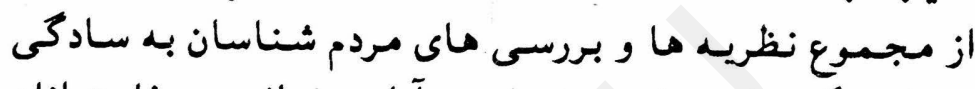

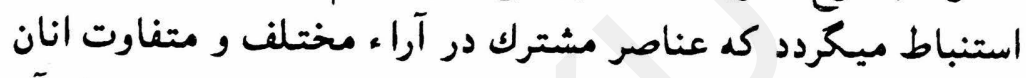

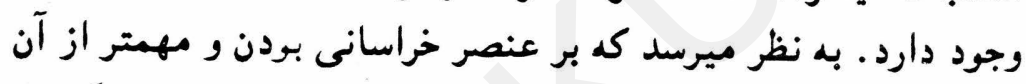

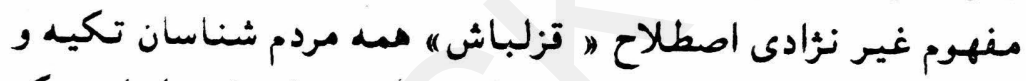

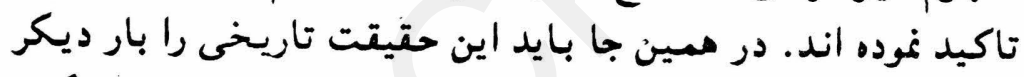

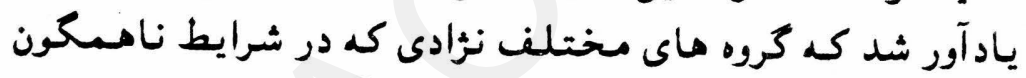

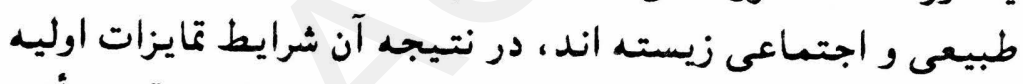

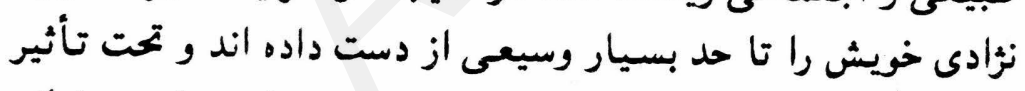

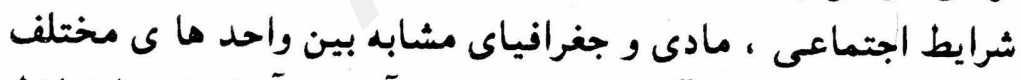

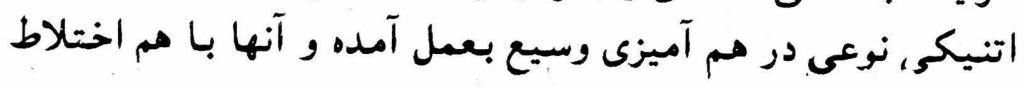
يافته اند.

اين حقيقت در مورد قزلباشان خويتر صدق ميكند. در صورتيكه

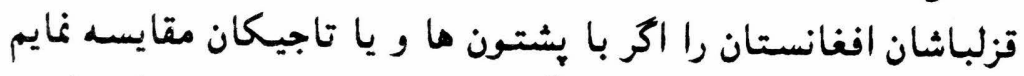

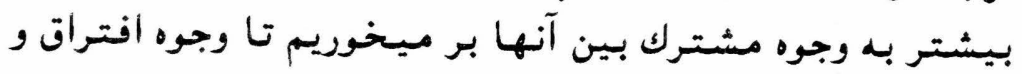

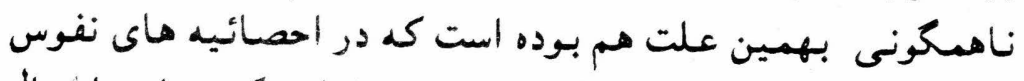

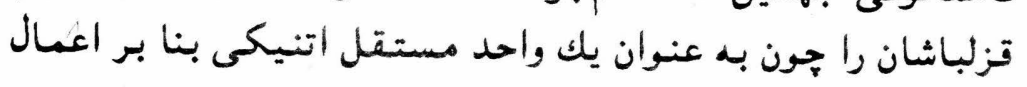




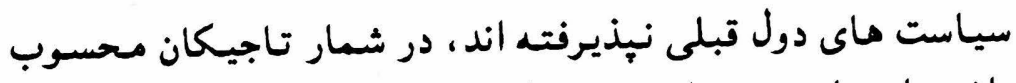

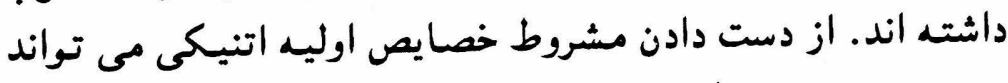

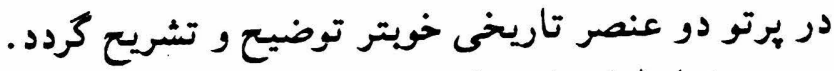

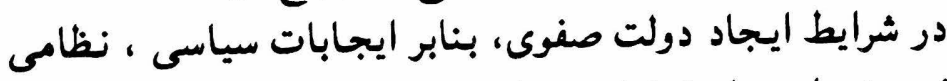

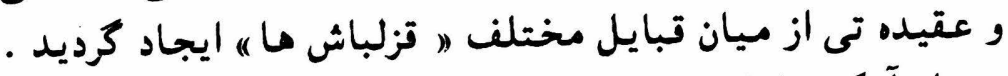

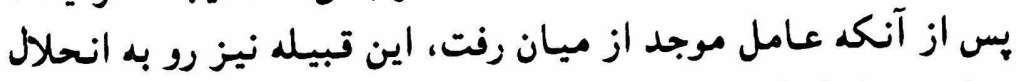

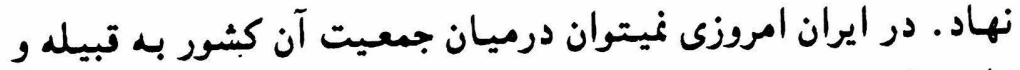

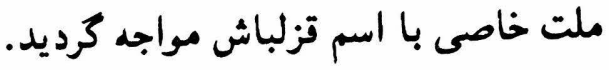

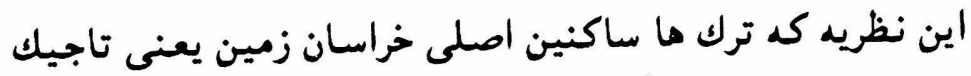

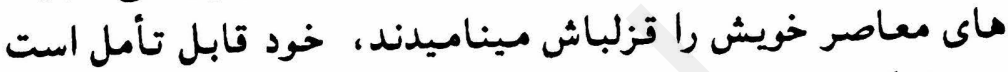

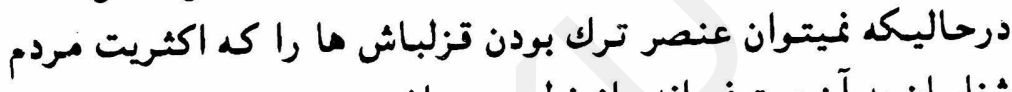

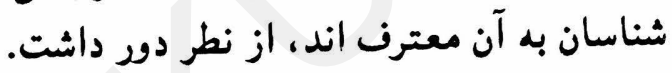

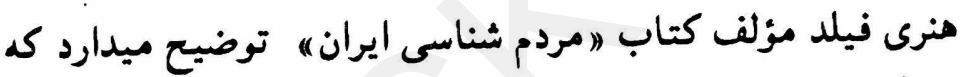

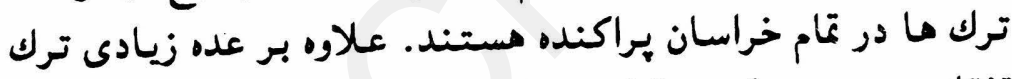

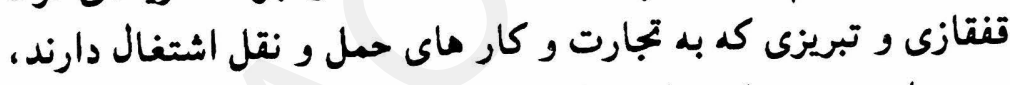

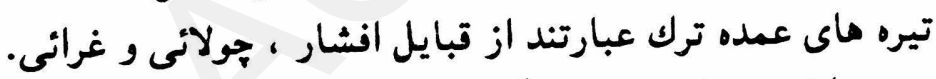

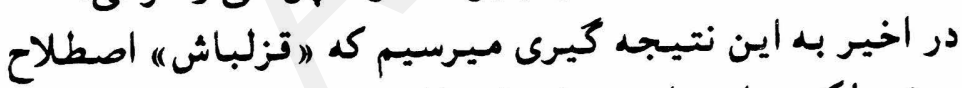

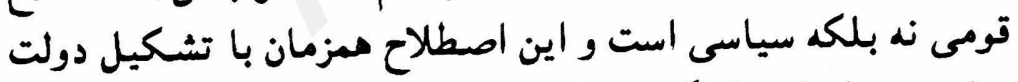

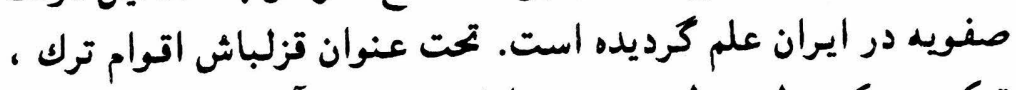

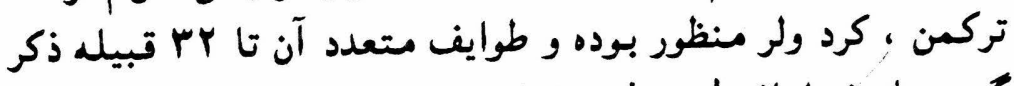

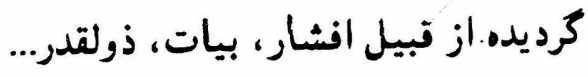

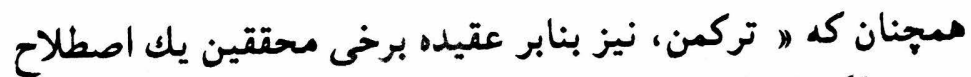
قومى نه بنكه اصطلاح سياسنى است. 


\section{مدارك فصل}

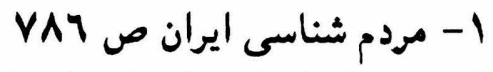

Y-تاريخ ايران از زيان باستان تا بايان قرن هجدمم ميلادى، ص

نويسنده مختصرا المنتول در تاريخ هزاره و مغول درياره تزلباش ماري

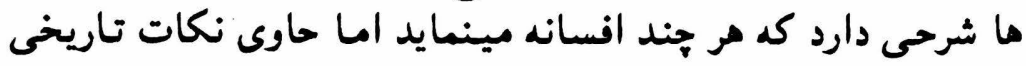
نيز است ـ او مى نوريسد:

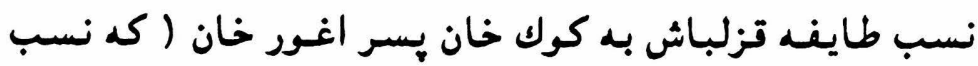

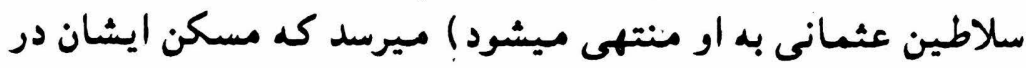

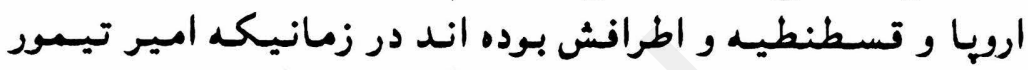

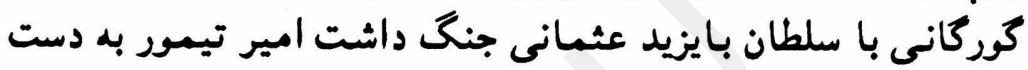

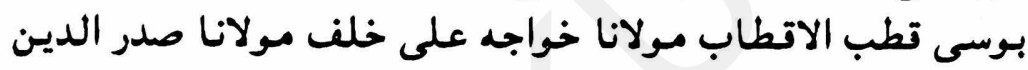

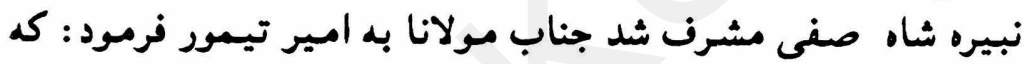

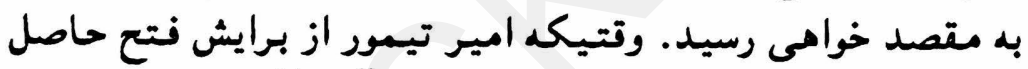

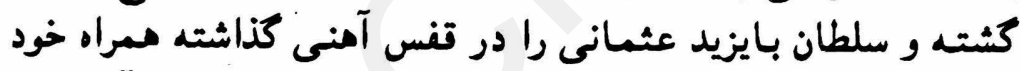

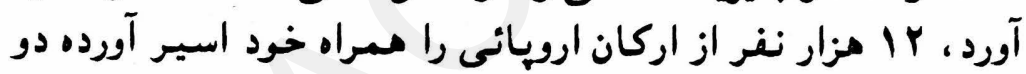

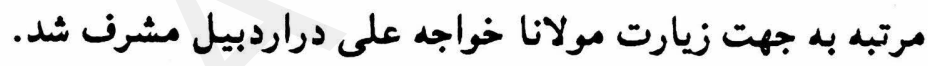

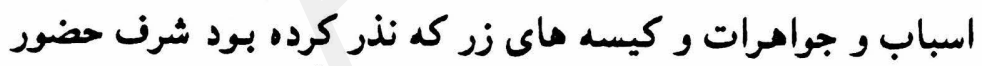

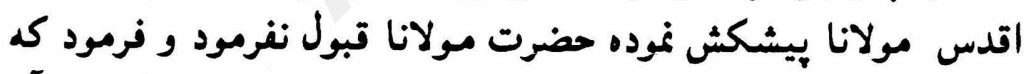

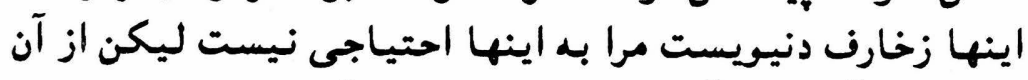

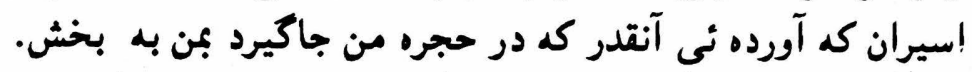

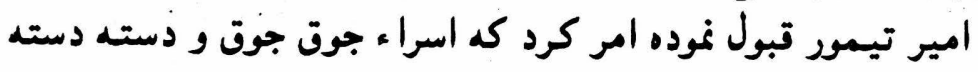

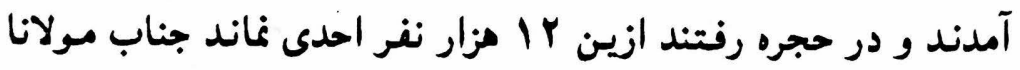

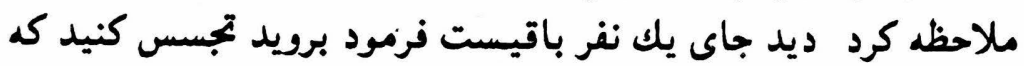

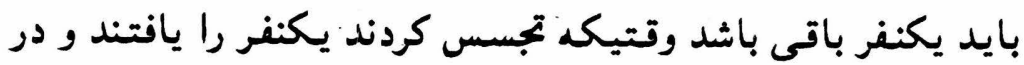

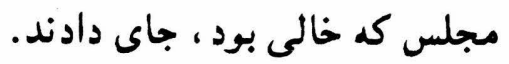
امير تيمور ازين كرامت اعتقادش بسيار زياد گشته دست مولانا 
را بوسيده مرخص كرديد و اينها كه آزاد كرده مولانا خواجه على مريل

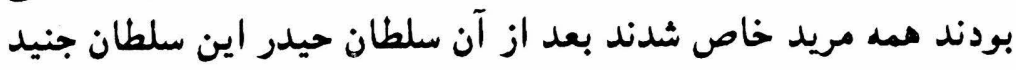

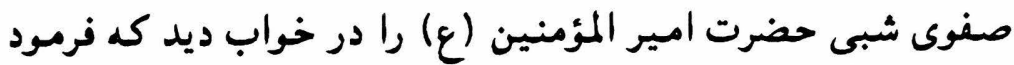

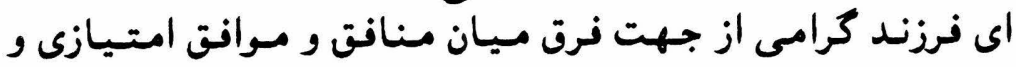

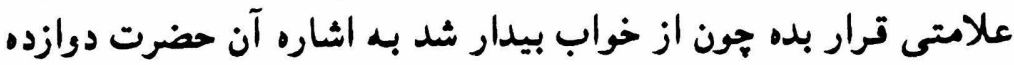

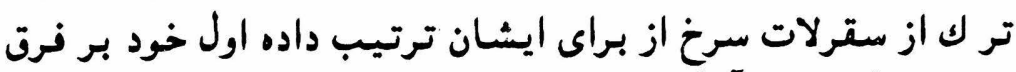

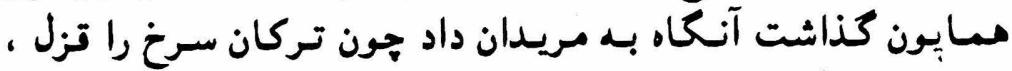

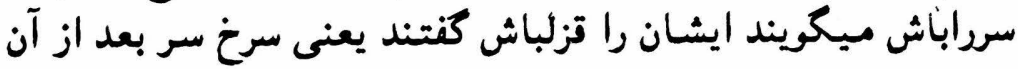

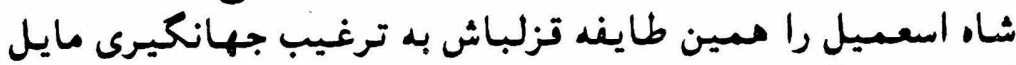

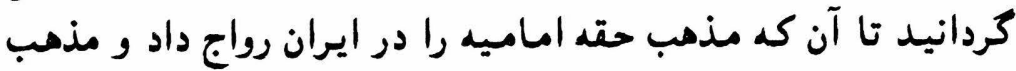

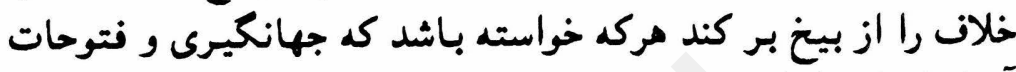
آنها را ملاحظد كند رجوع بـ تاريخ سلاز سلاطين صفويه نمايد.

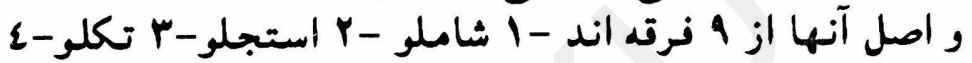

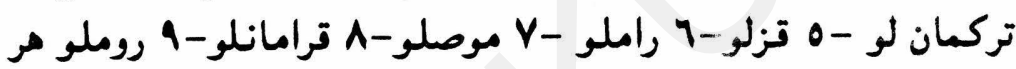

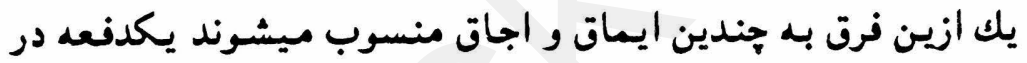

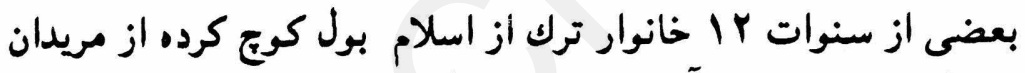

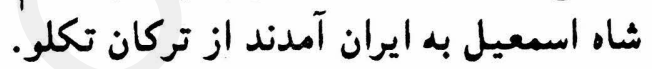

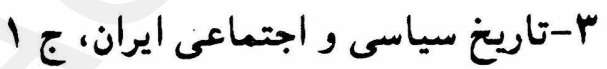

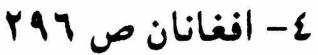

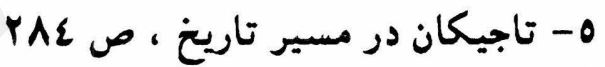

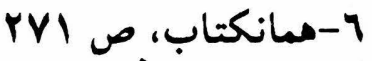

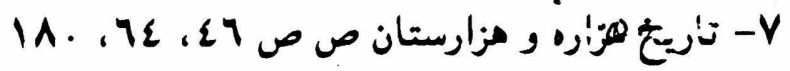

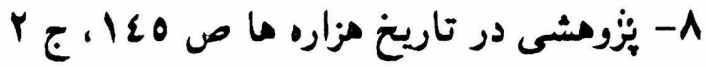

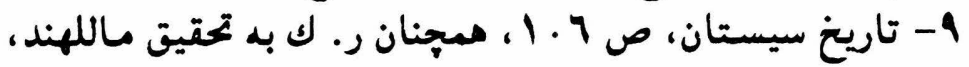

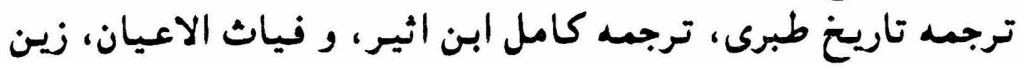

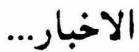

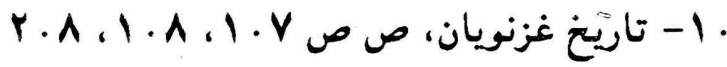

rr 


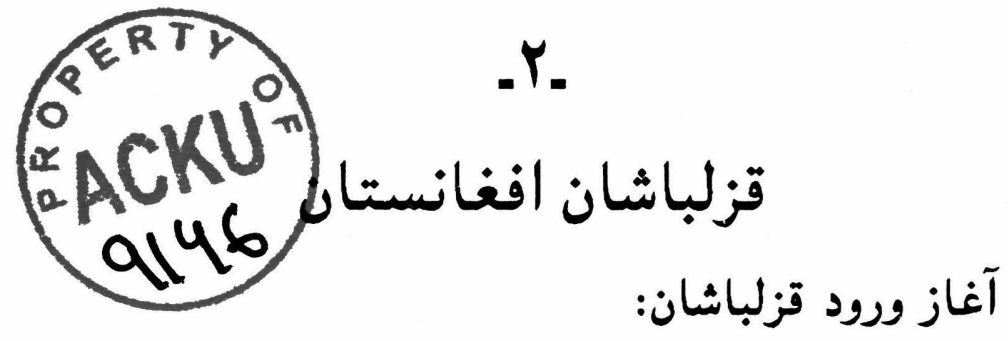

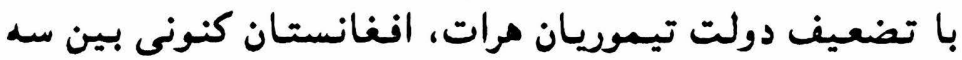

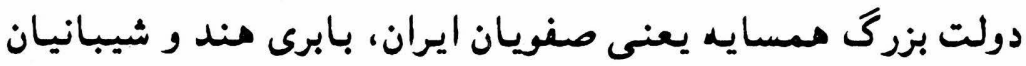

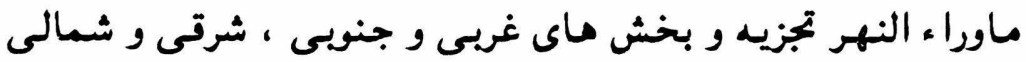

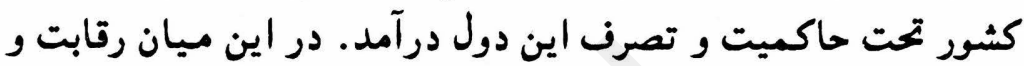

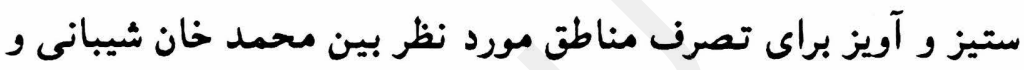

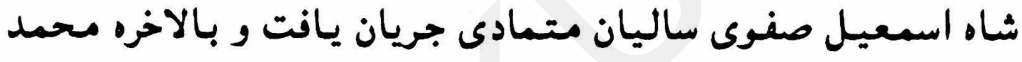

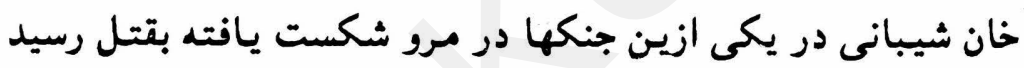

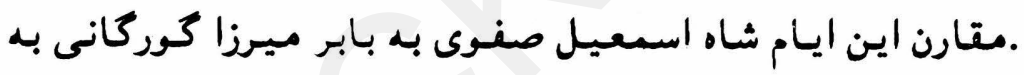

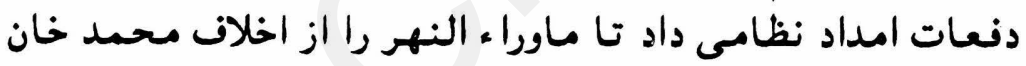

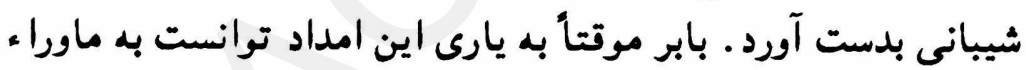

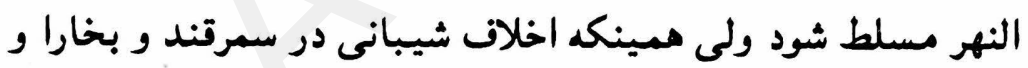

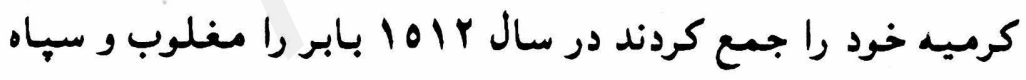
امدادى صفوى را معدوم نمودند.

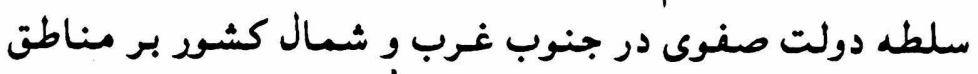

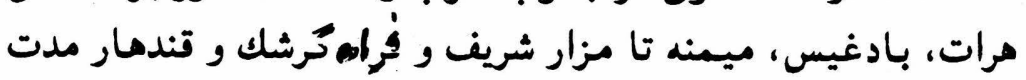

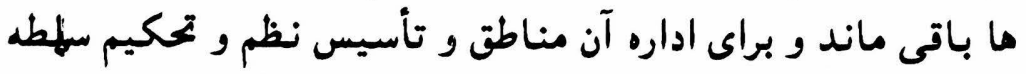

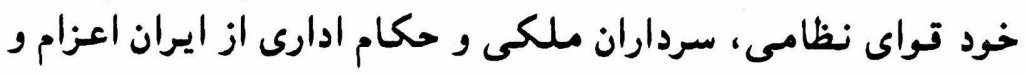
جايكزين كرديدند.

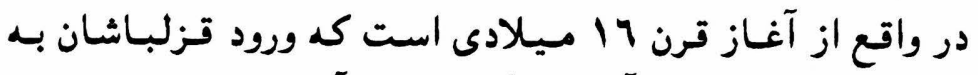

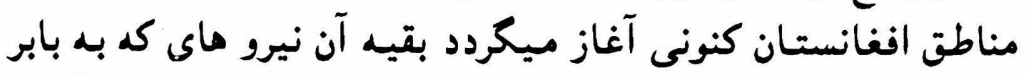


ميرزا امداد شده بود ميراه با تعداد كثيرى امراء، حكام، سران

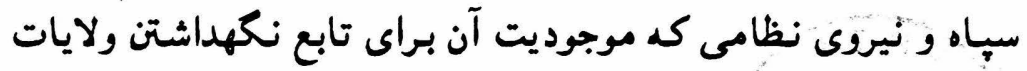

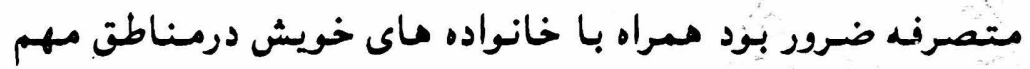

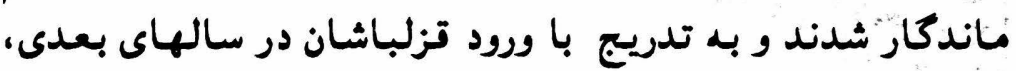
تعداد آنان افزايش يافت.

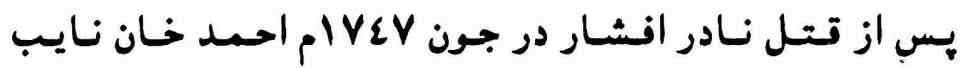

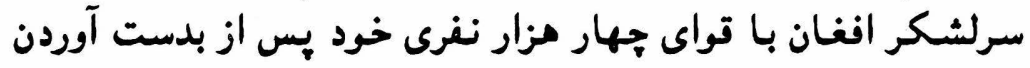

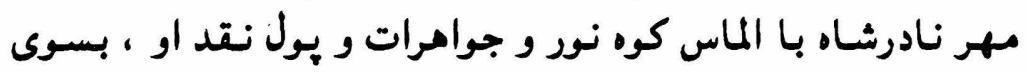

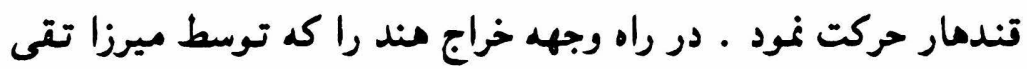

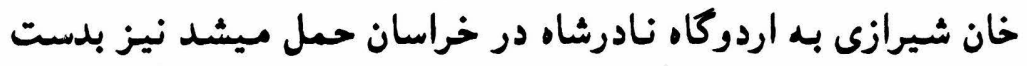

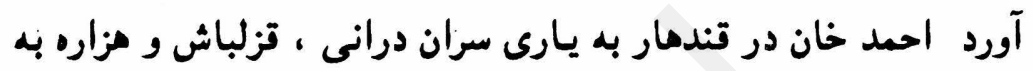

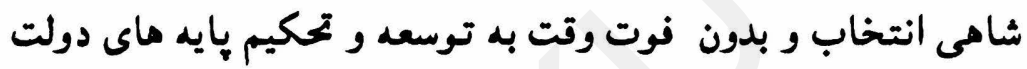

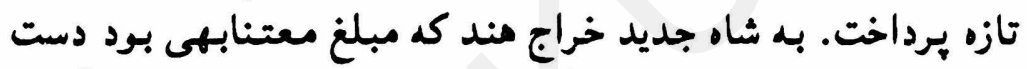

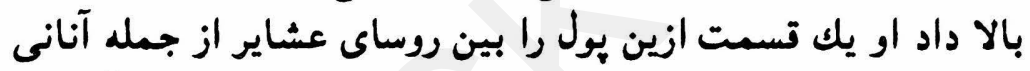

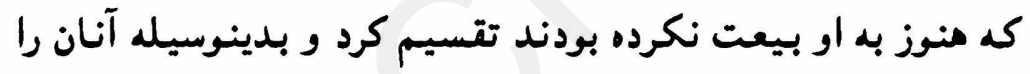

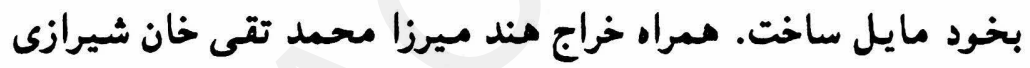

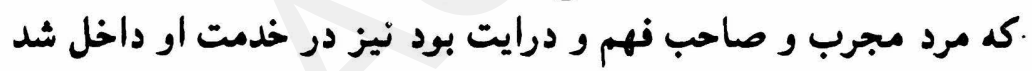

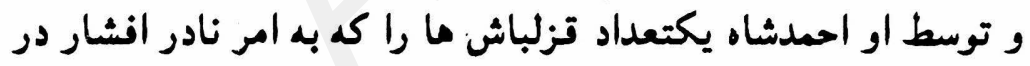

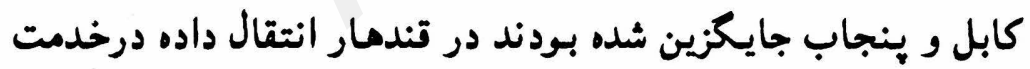

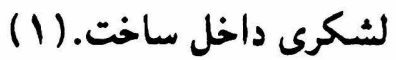

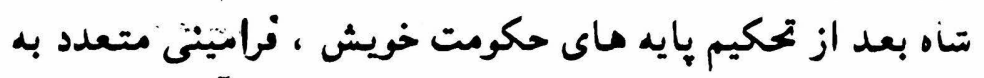

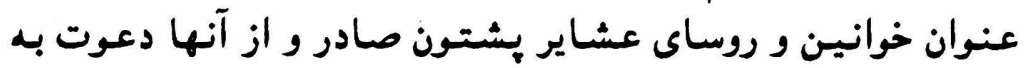

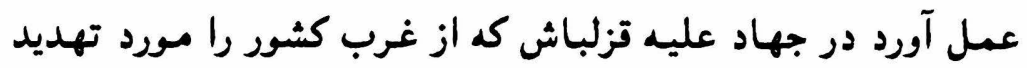

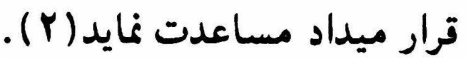

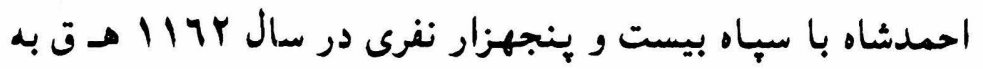

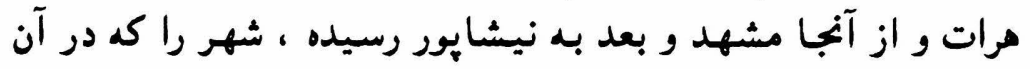

rq 
جعفرخان قرابيات يكى از امراى محلى امارت داشت، بـ محه محاصره

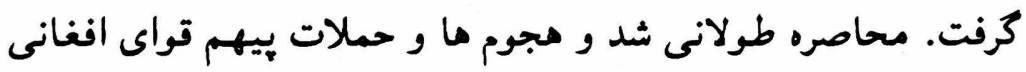

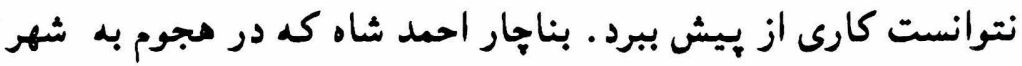

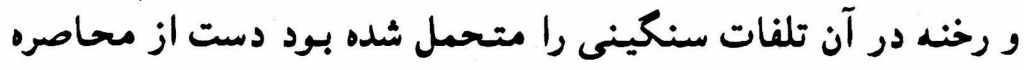

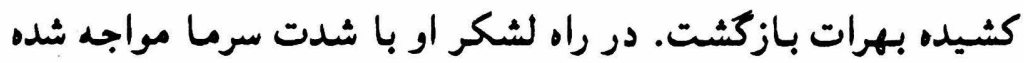

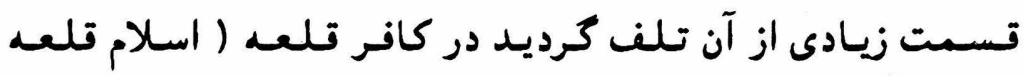

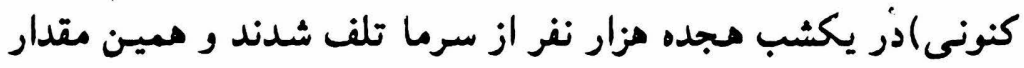

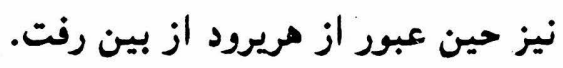

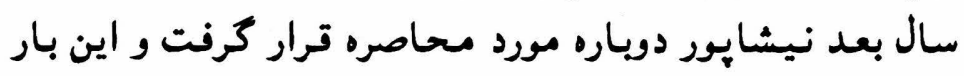

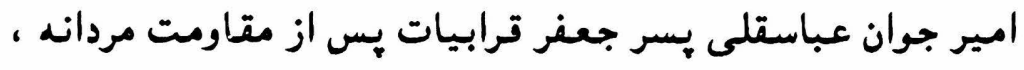

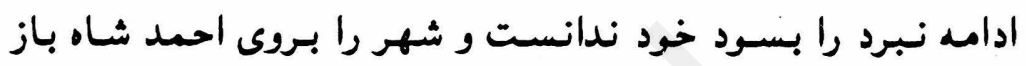

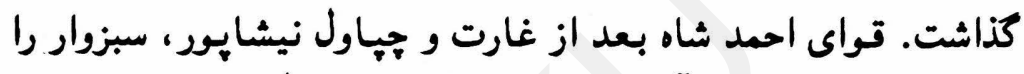

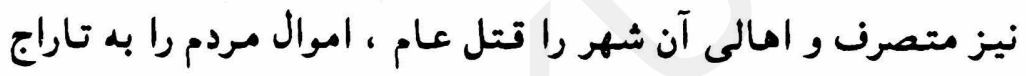

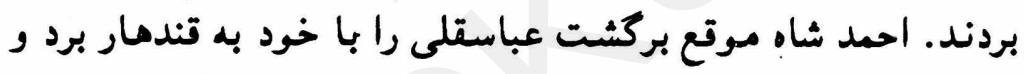

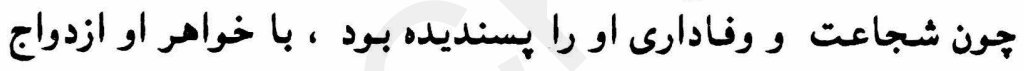

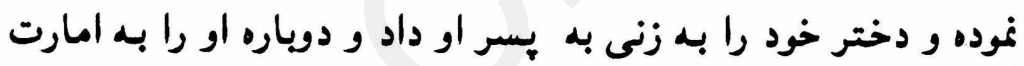

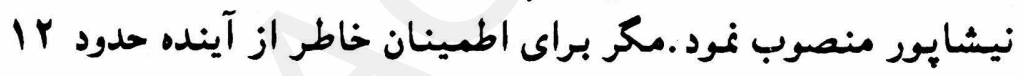

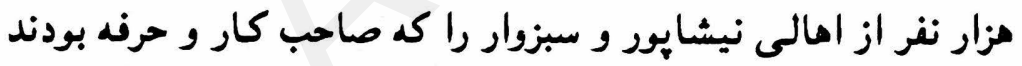

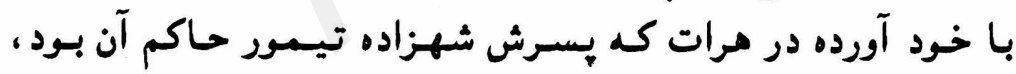

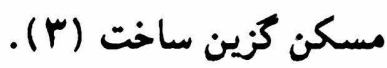

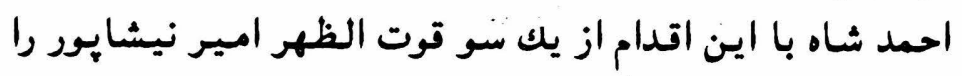

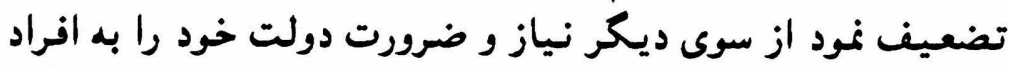

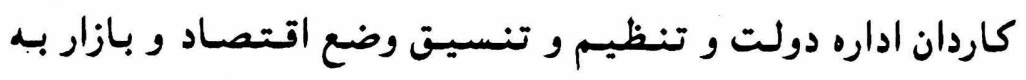
صاحبان مشاغل و حرفه ما مران مرفوع ساخت.

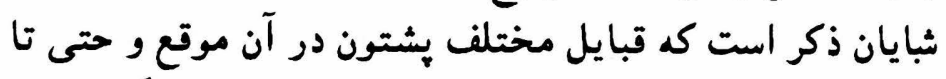

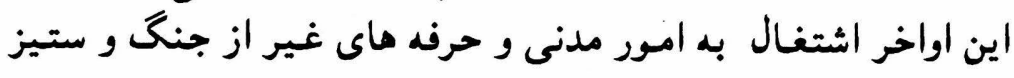


را دون شان خويش ميدانستند و شغل عمده آنان مهان جنگ و ستيز

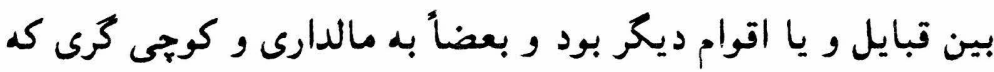

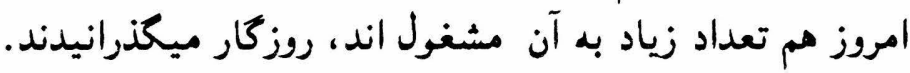

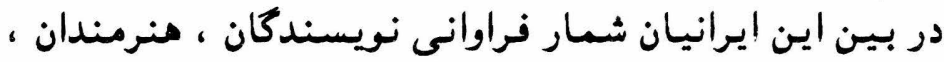

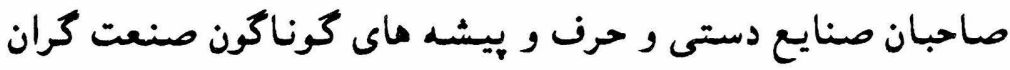

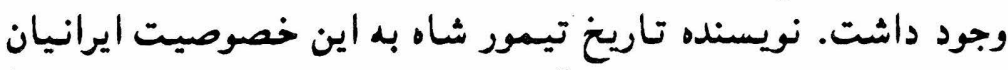

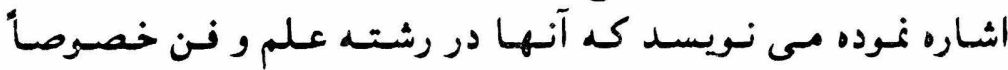

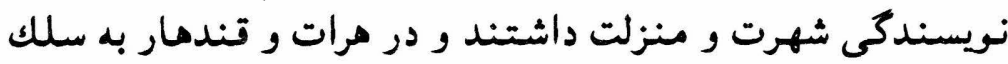
خادمان دولت منسلك كرديد ميدند

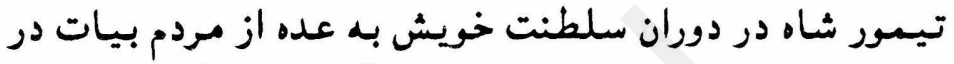

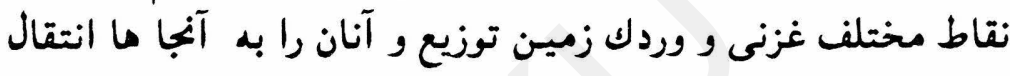
داد.

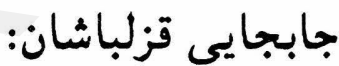

مرحوم فيض محمد كاتب در نرُاد نامه افغان تحت عنوان فرقه

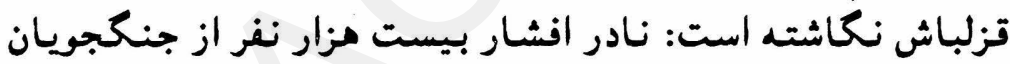

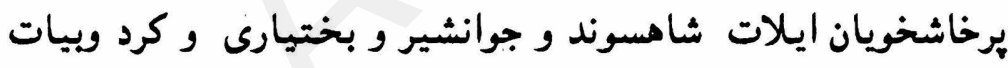

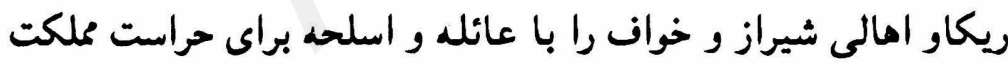

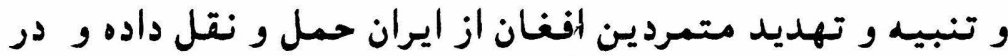

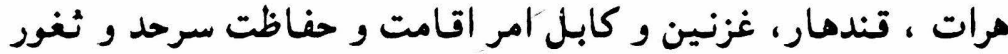

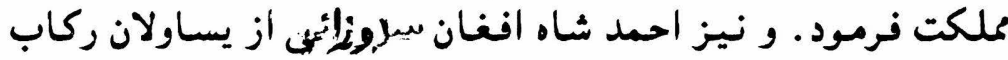

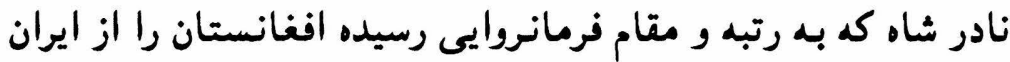

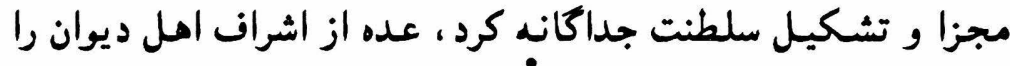

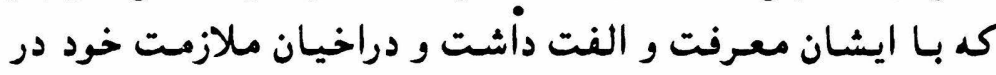

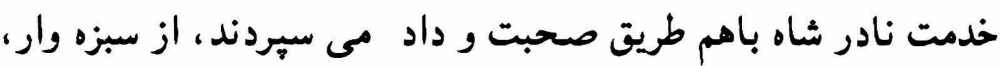

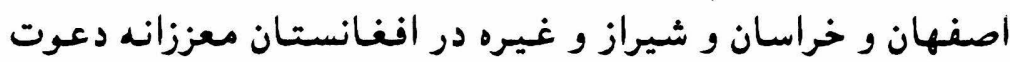


نموده، زمام مهام مملكت و نظم و نست امورملت و رتق و فتق ادارات

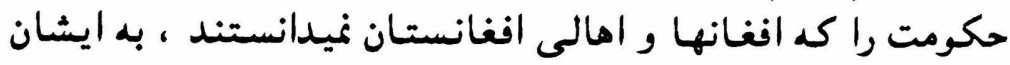

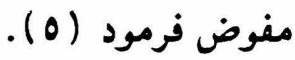

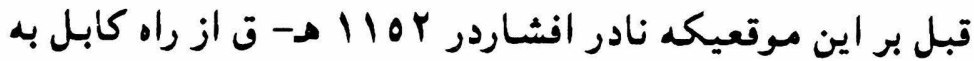

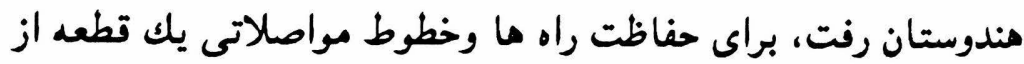

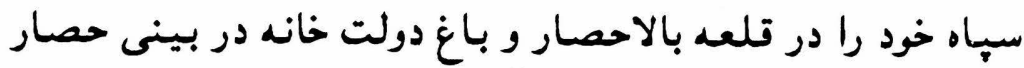

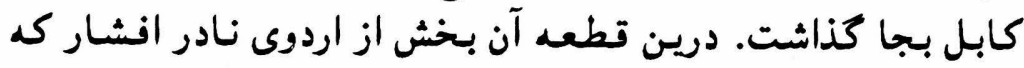

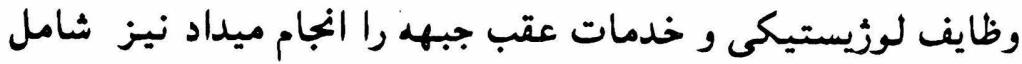

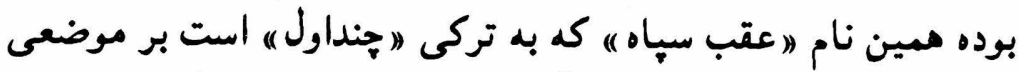

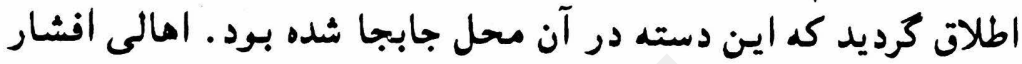

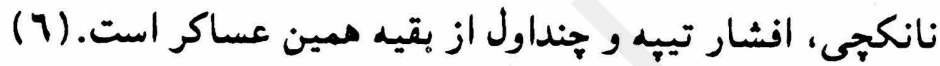

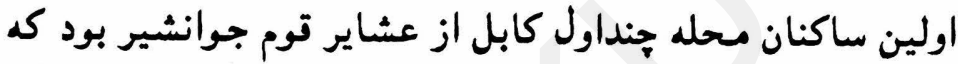

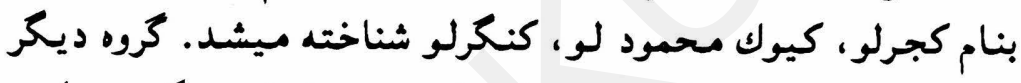

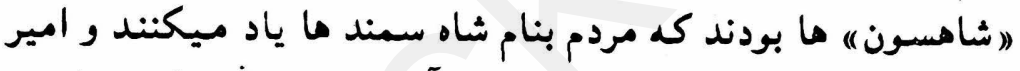

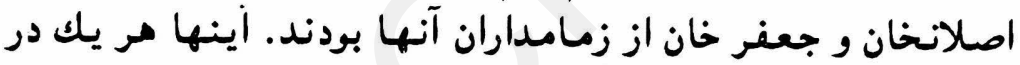

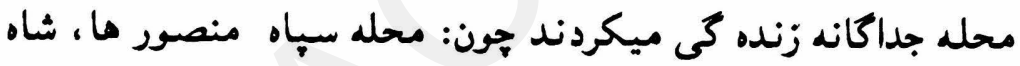

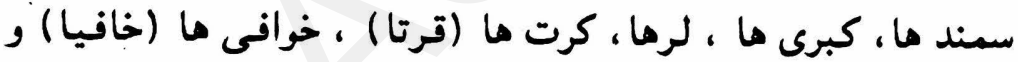

نادر افشار در موقع بازكشت از مند طوريكه قبلاً از قول فيض غيره.

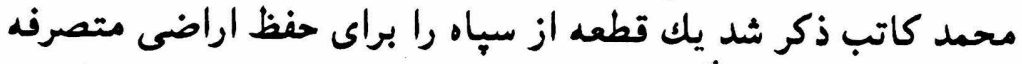

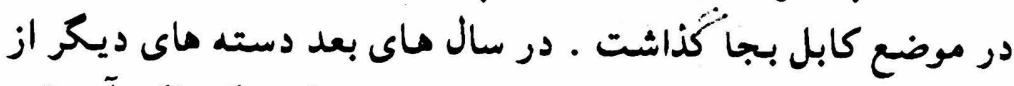

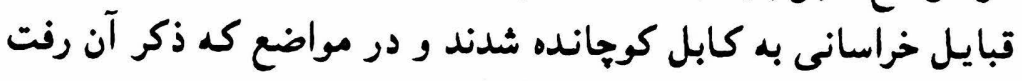

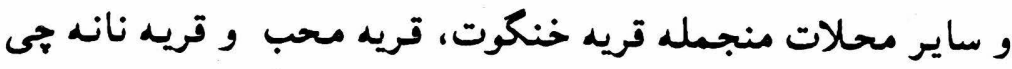

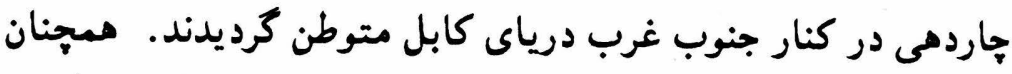

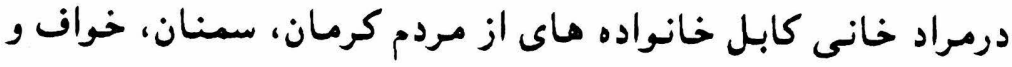

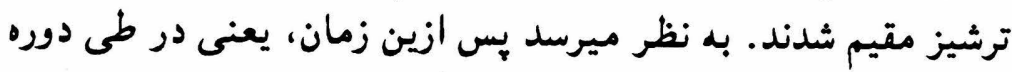


هاى زمامدارى نـادرشاه افشار و احمد شاه درانى جابجاى كتلوى اقوام خراسانى تكميل شده باشداري

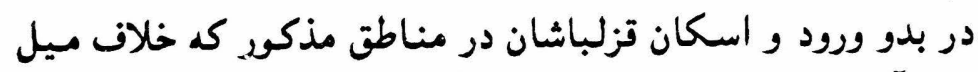

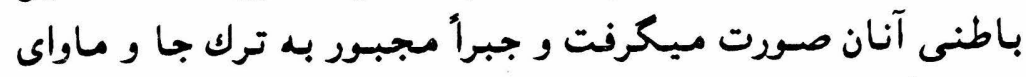

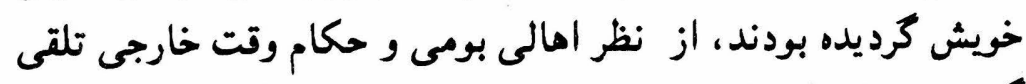

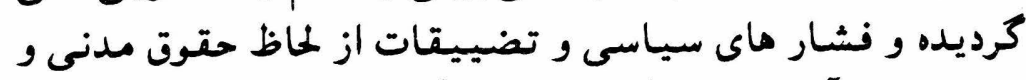

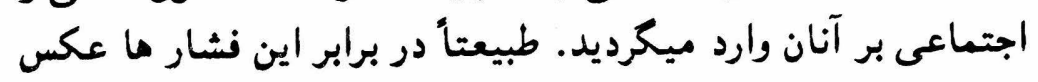
العمل مائ صورت ميكرفت.

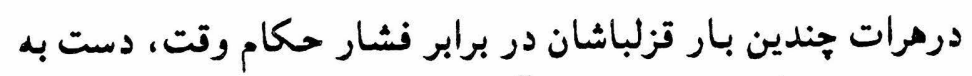

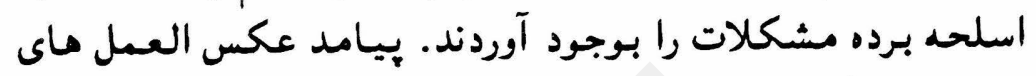

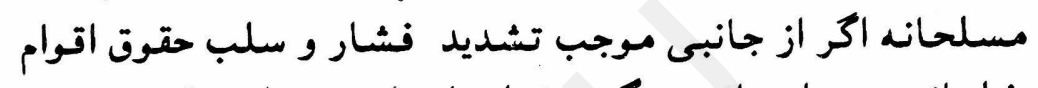

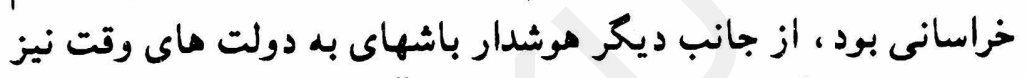

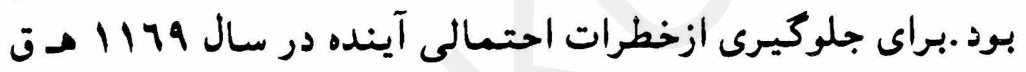

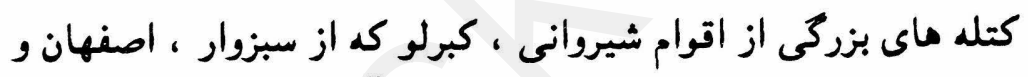

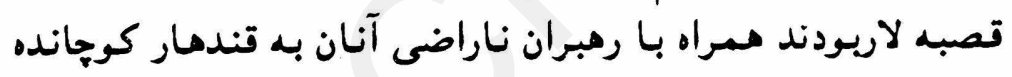

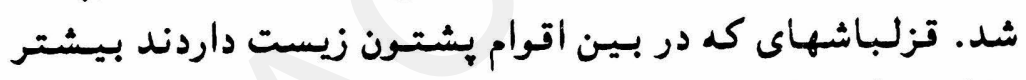

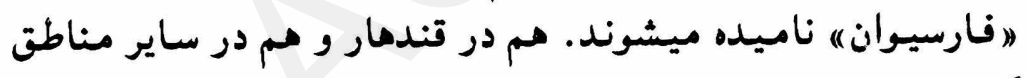
كثور.

با وجود اين ، دولت ماى وقت خود را ناكزير مبيافتند تا حمايت

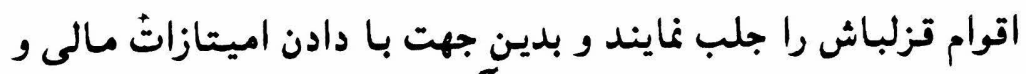

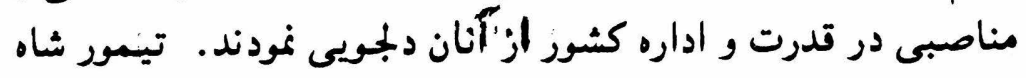

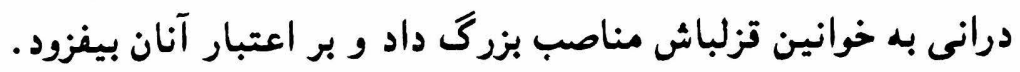

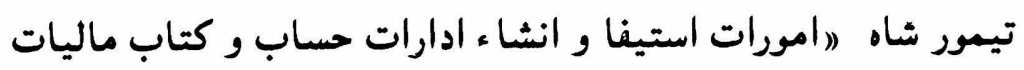

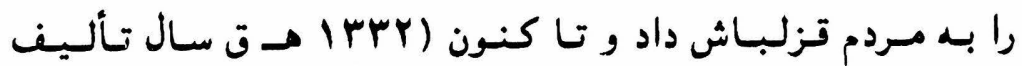

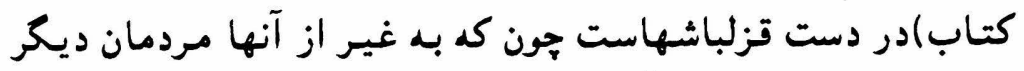

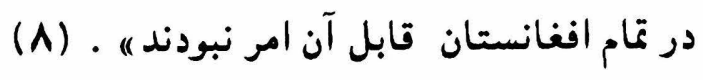


مدارك اين فصل:

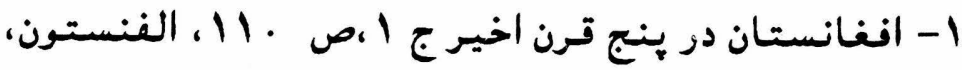

افغانان، ص أب

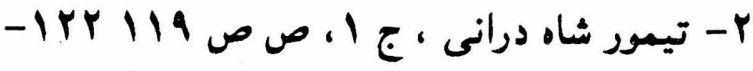

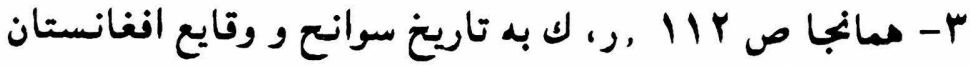

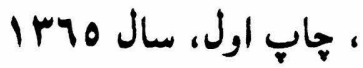

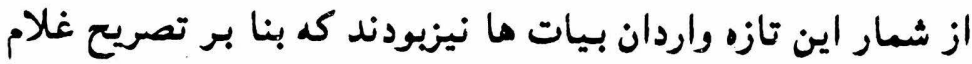

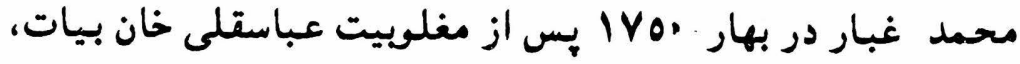

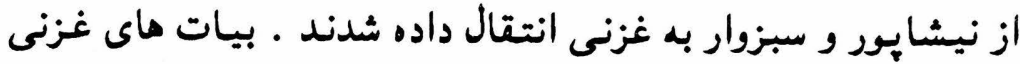

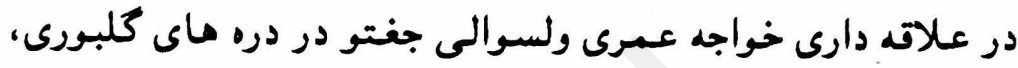

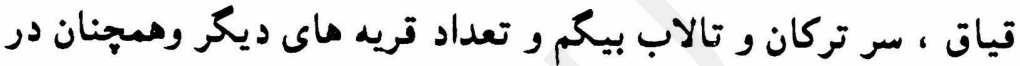

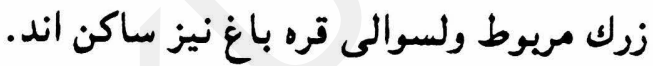

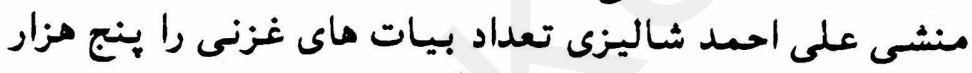

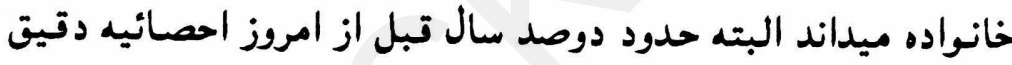

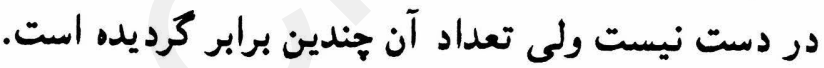

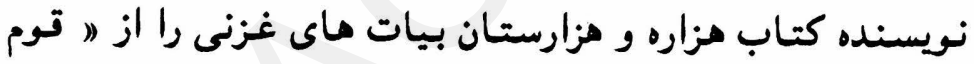

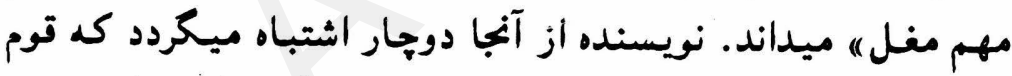

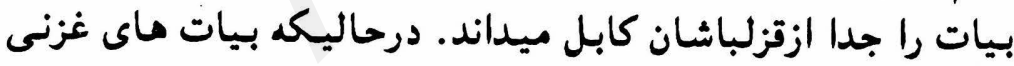

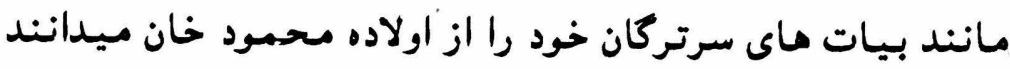

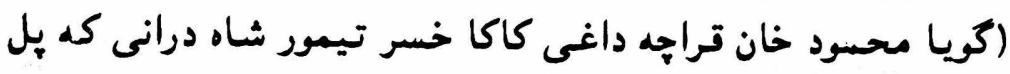

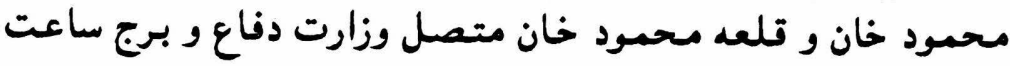

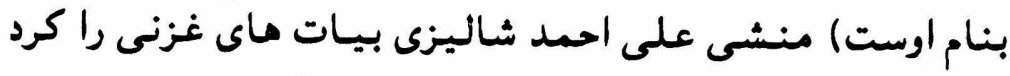

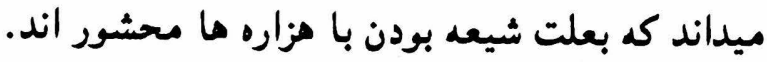

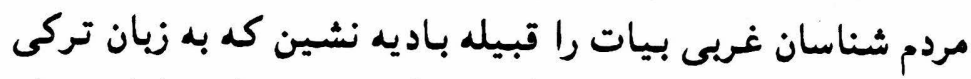

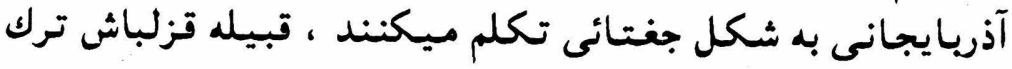
ميدانند . بيات ما در آسياى صغير و برخى در ائى ايران مستقر شدند و 
بخشى در شمال بروجرد و خرم آباد سكونت دارند . بعضى از آنها

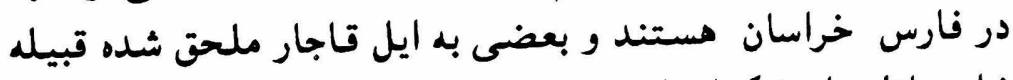

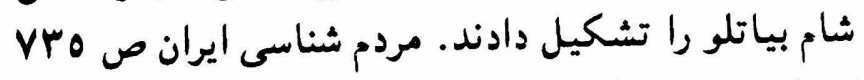

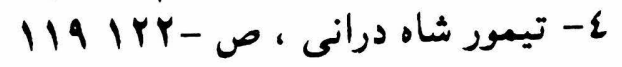

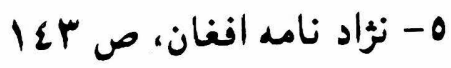

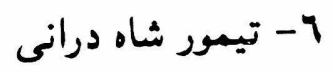

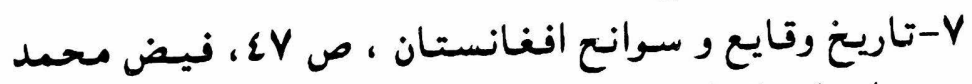

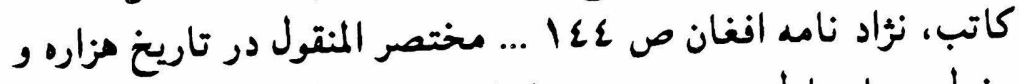

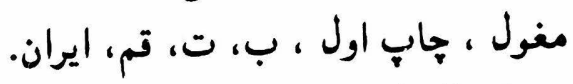

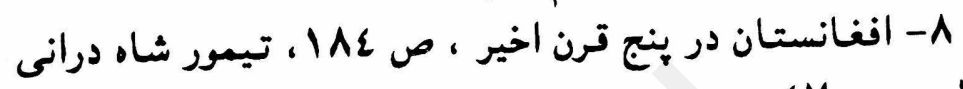

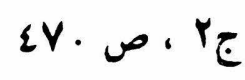
قزلباشها در مرات وسيعاً از شهزاده محمود در برابر برادرش

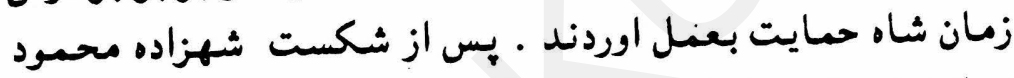

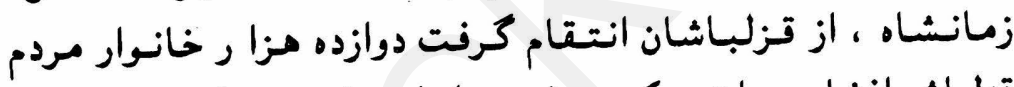

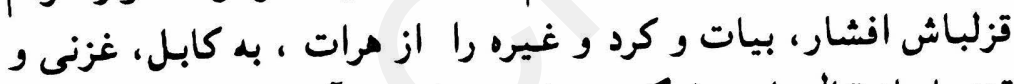

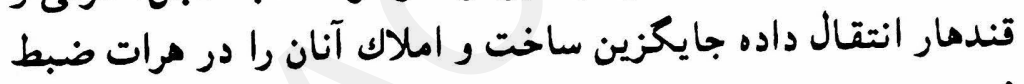
نمود. 


\section{r.}

\section{نقش قزلباشان در اداره و دولت}

علل جابجايى قزلباشان:

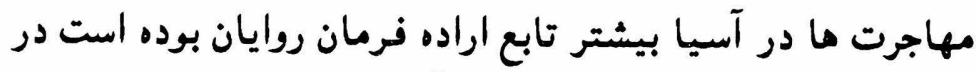

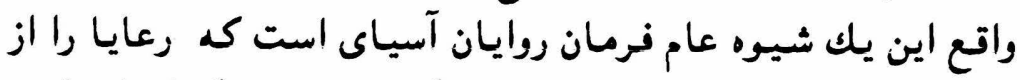

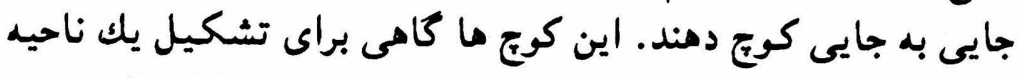

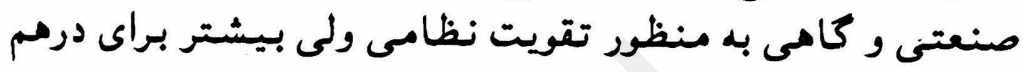
شكستن توان شورشها ستر

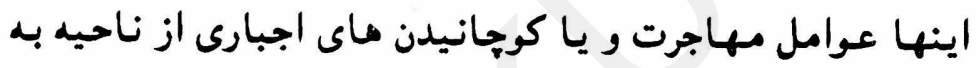

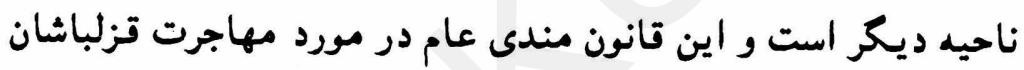

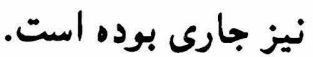

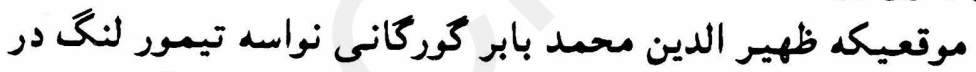

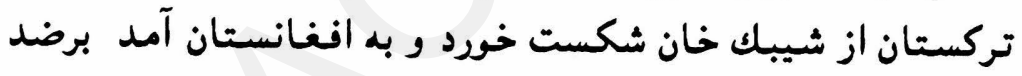

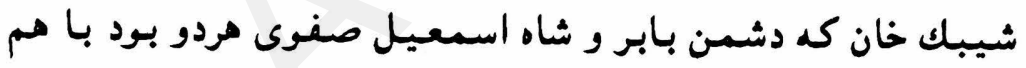

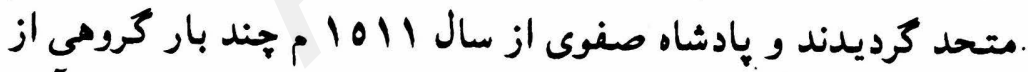

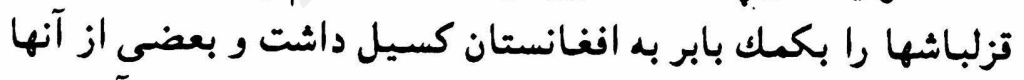

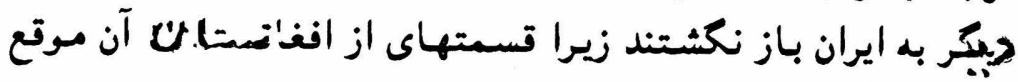
در تصرن ايران بود مان. شايان ذكر است بس از كشته شدن مرشد قليخان جمان بمعى از همين

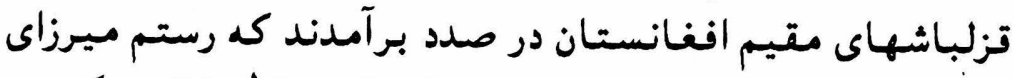

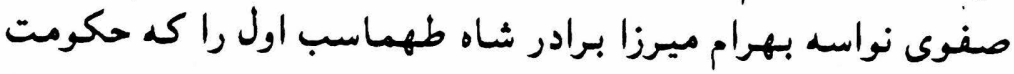

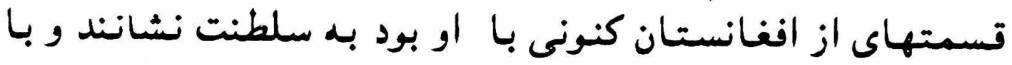




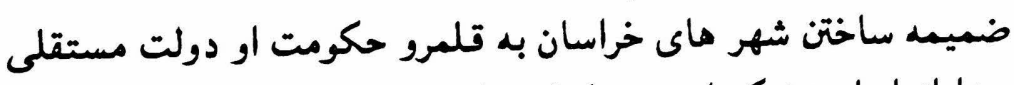

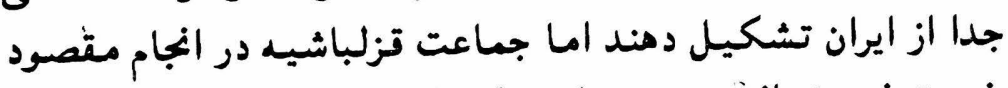

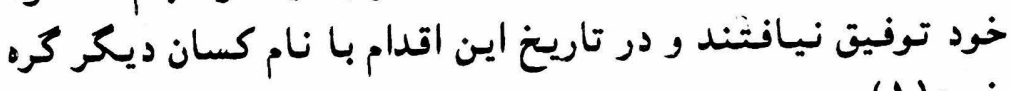

خورد (1)

براى آكامى از منالفت ماى رستم ميرزا و تزلباشهاى متيم

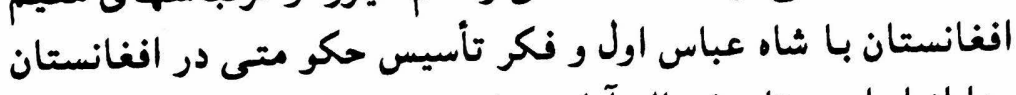

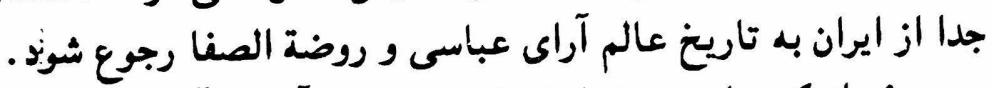

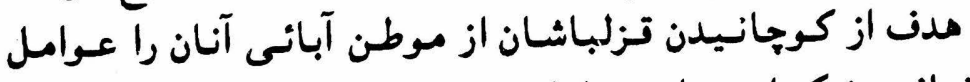

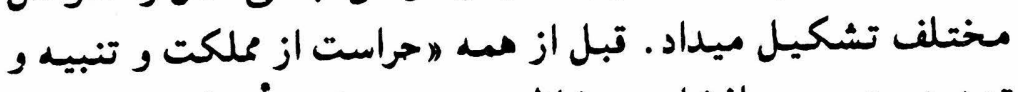

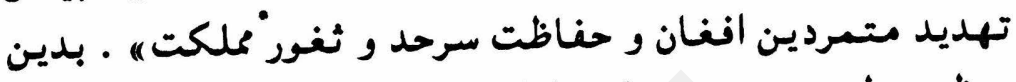

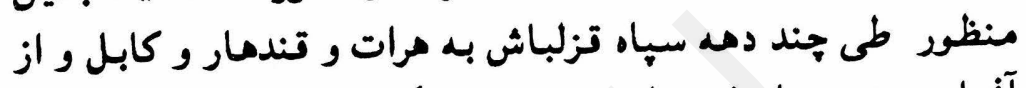

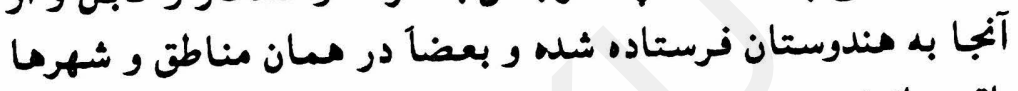
باقى ماندند.

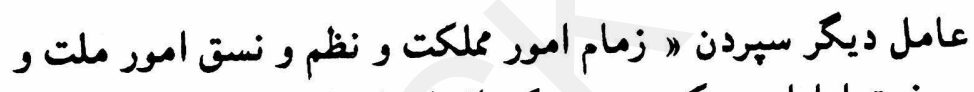

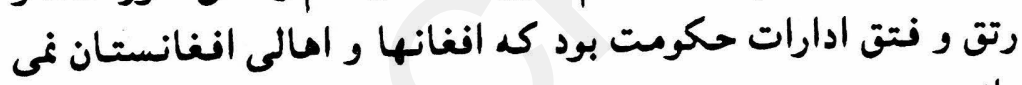
دانستنده .

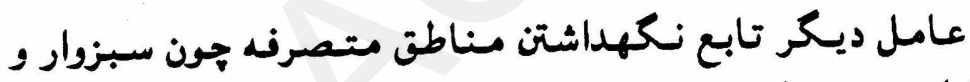

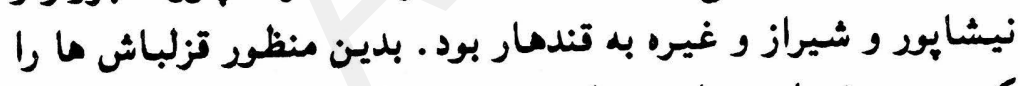

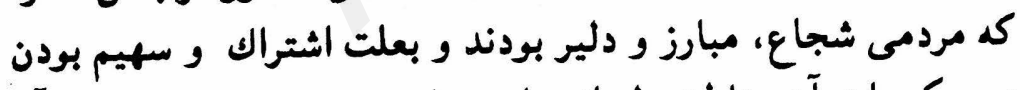

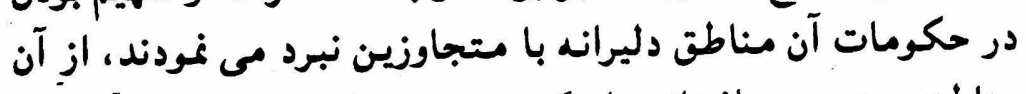

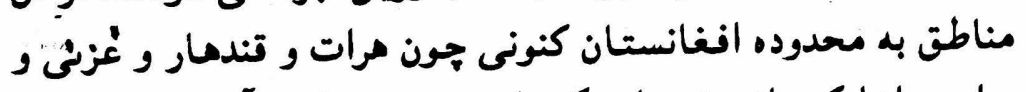

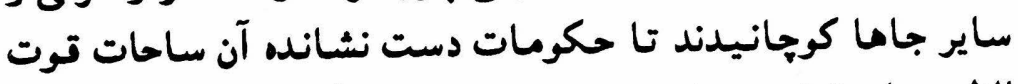

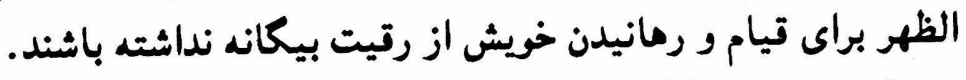

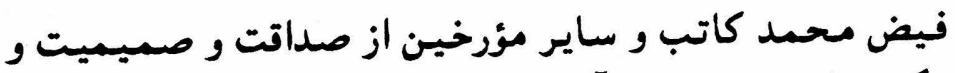

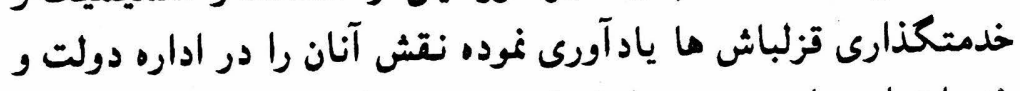

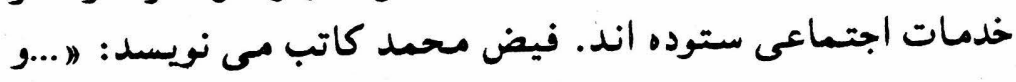


ايشان (قزلباش ها) از اخلاص و صداقت رمكراى خدمت شده ، از

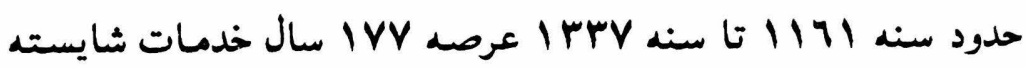
به ملك و ملت و دولت و سيّاه و رعيت به تقديم رسانيده ، تا اوايل

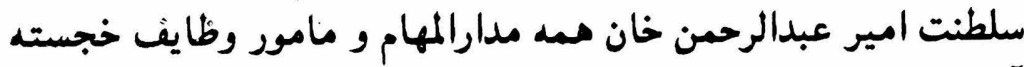

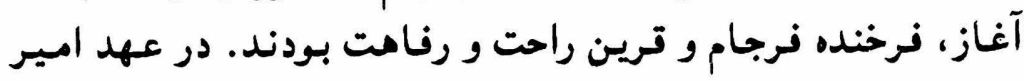

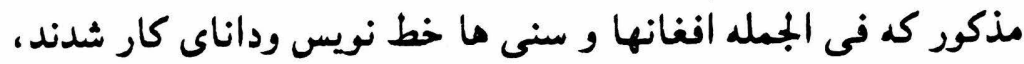

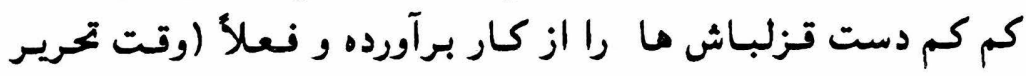

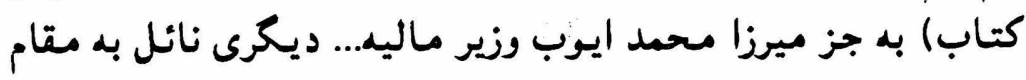

ماموريت نيست... " (Y)

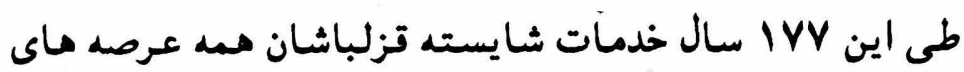

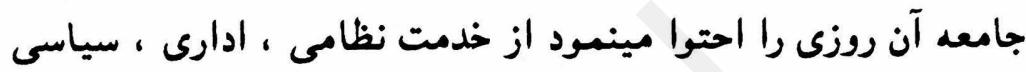

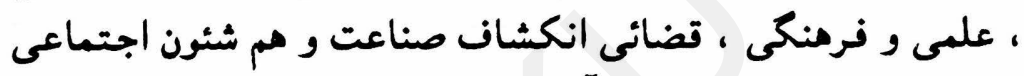

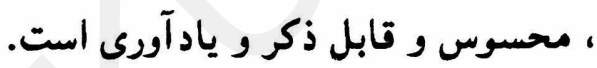

\section{سهيم ساختن قزلباشان در اداره دولت :}

در سطور بعدى به نقش و موقف قزلباشان از منكام متوطن شدن

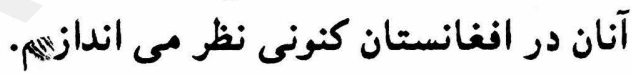

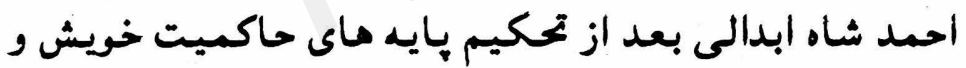

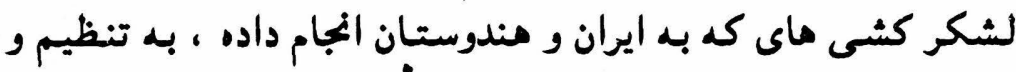

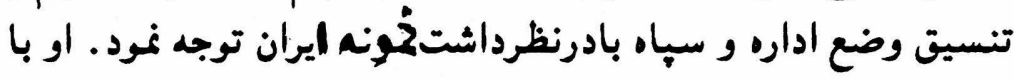

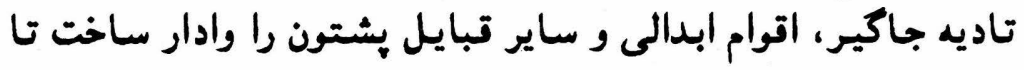

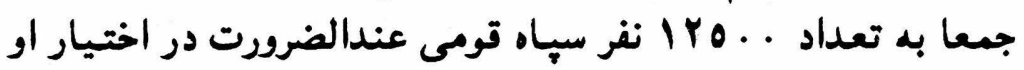

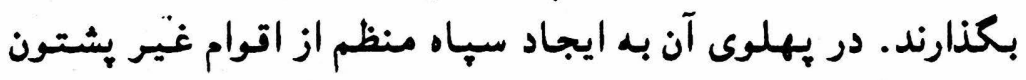

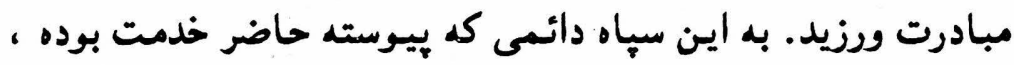

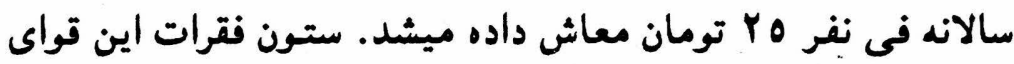


منظم شاهى كه بنام غلامان شاهى يا " غلام خانه) ياد ميشد عمدتا

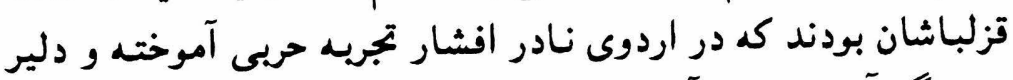

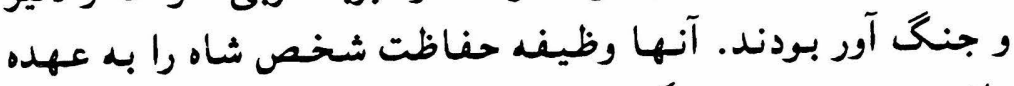

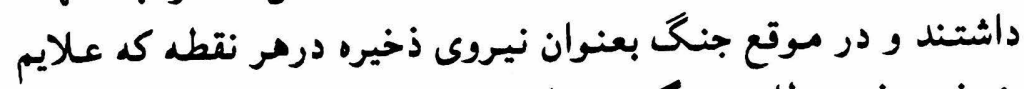

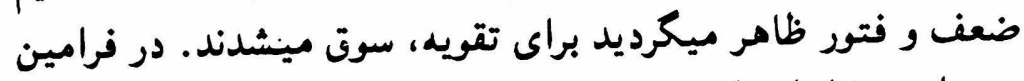

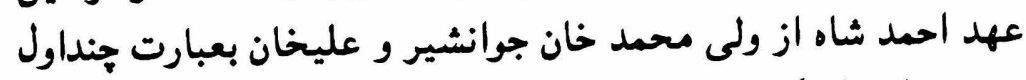

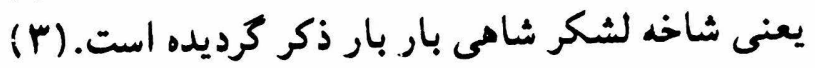

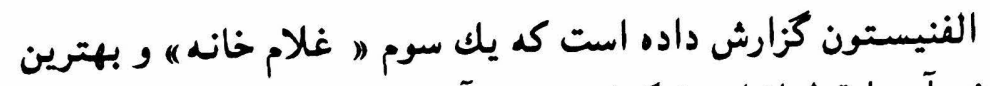

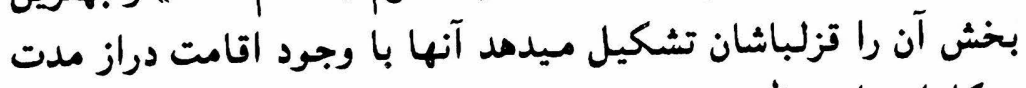

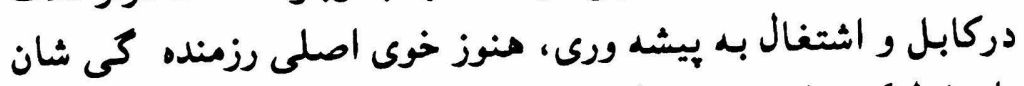

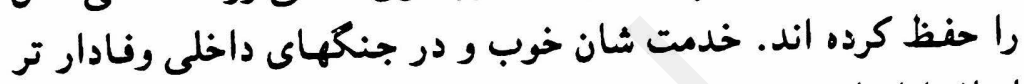
از افغانان اند.

تزلباشها در نتح كابل و يشـاور و در جنـكهاى كه احمد شاه

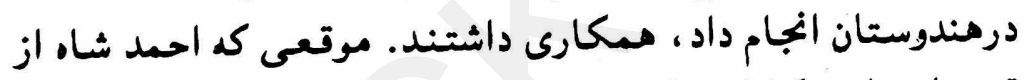

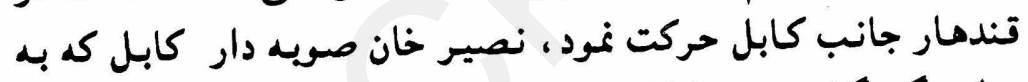

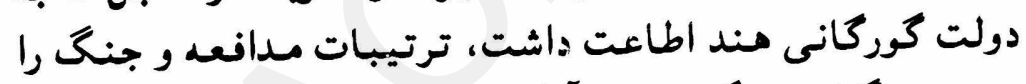

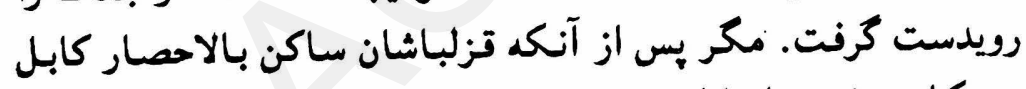

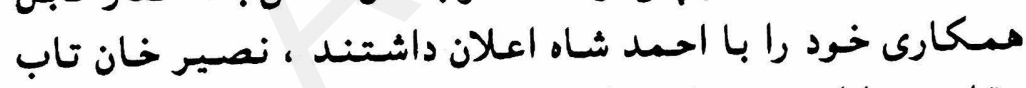

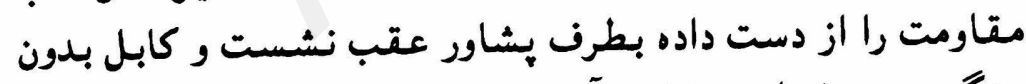
جنگ بد تصرف احمد شاه درآمد.

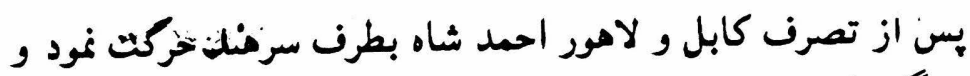

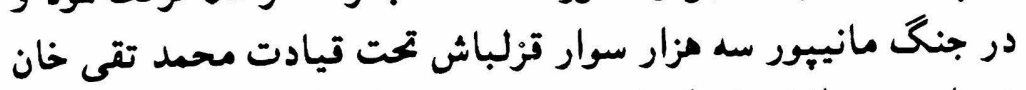

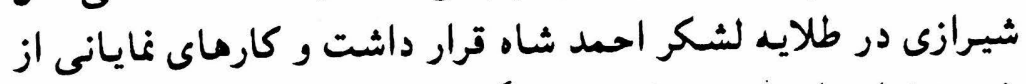

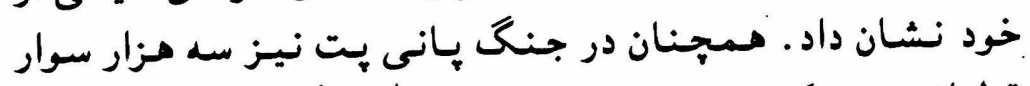

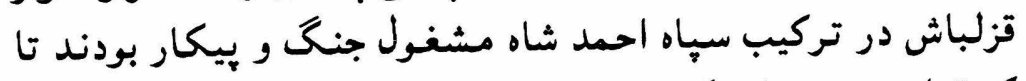

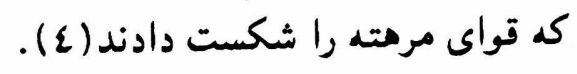


يس از مرگ احمد شاه مبارزه براى كسب قدرت بين سران قبايل

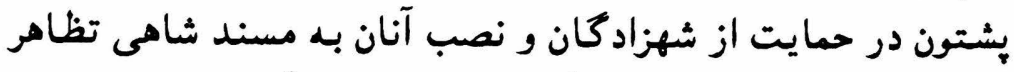

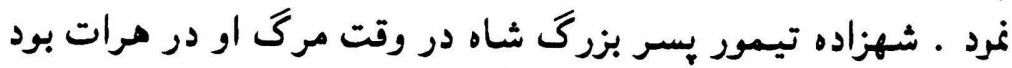

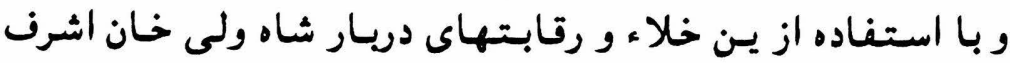

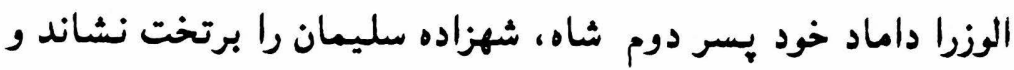

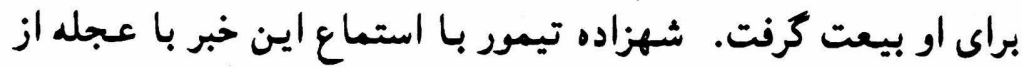

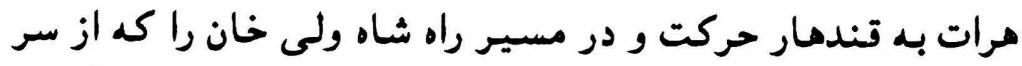

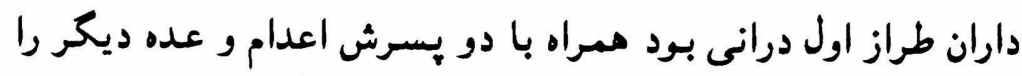

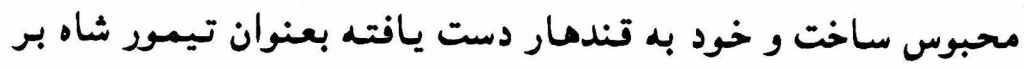

تخت نشست.

مخالفت و معاندت امرا و سران تبايل با اختيارات وسيع تيمور

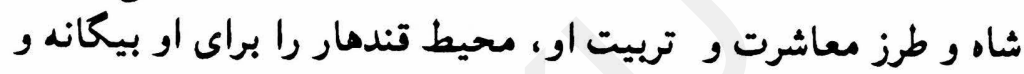

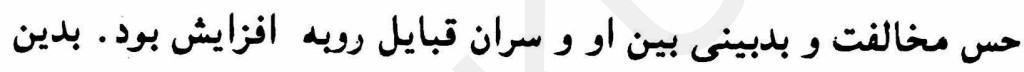

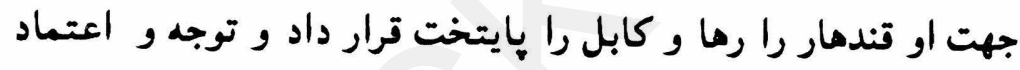

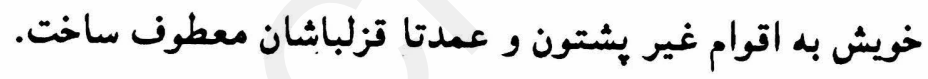

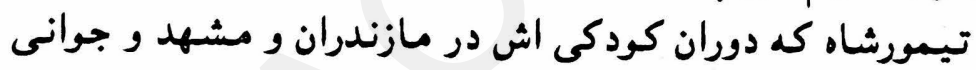

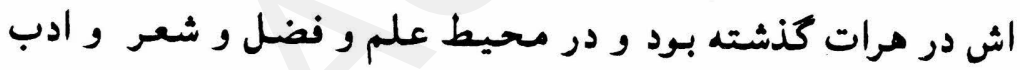

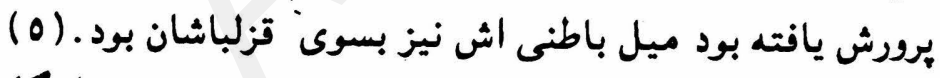

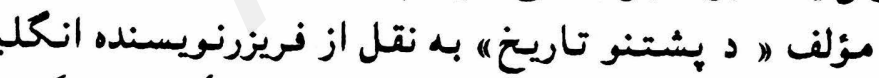

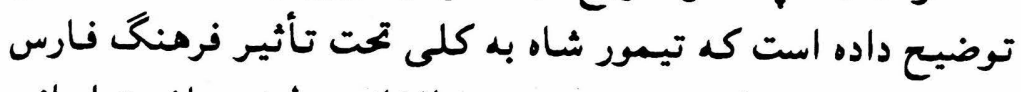

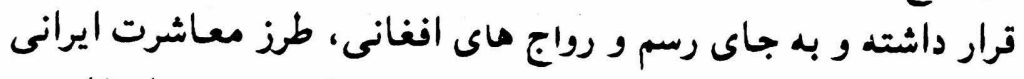

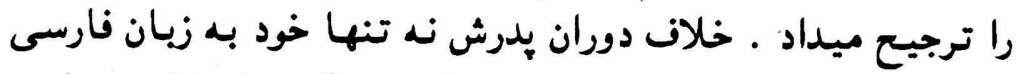

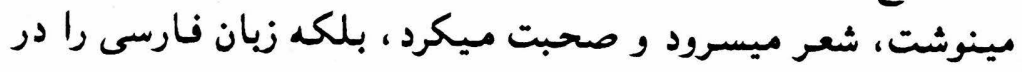

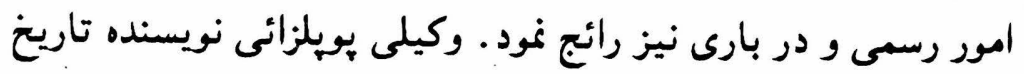

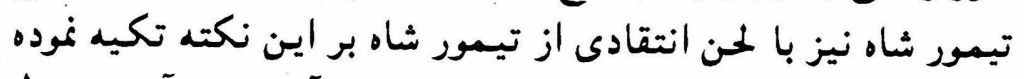

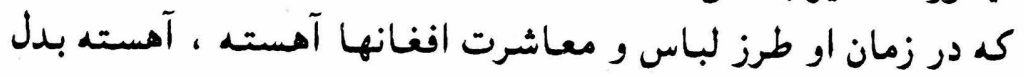


شد و خوى ماى سرداران افغان بـ طرف قزلباشان و ايرانيان تمايل

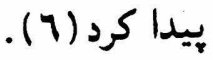

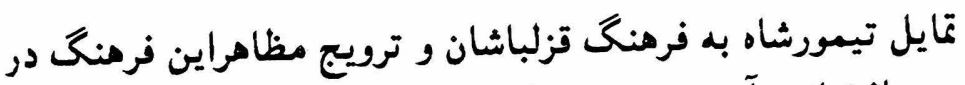

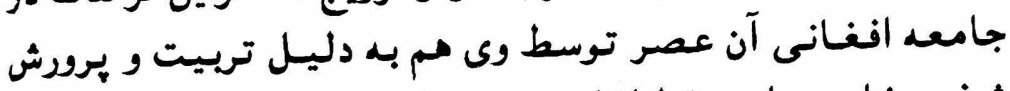

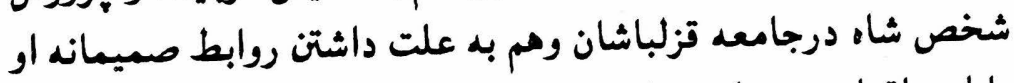

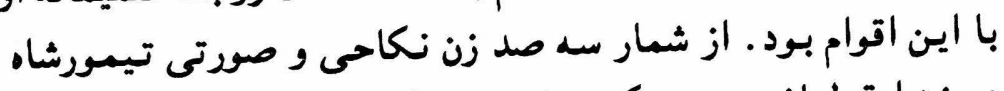

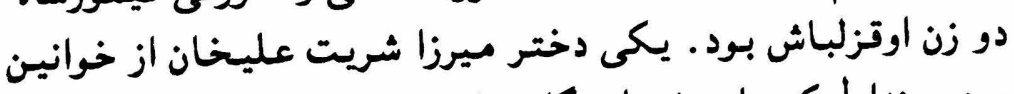

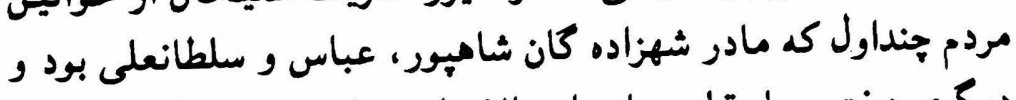

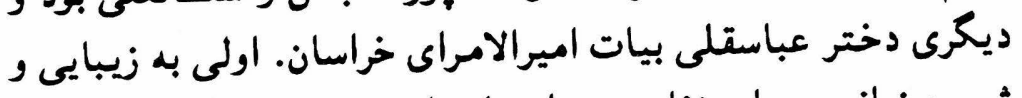

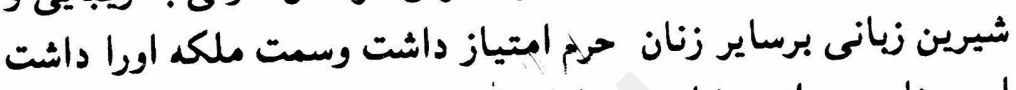

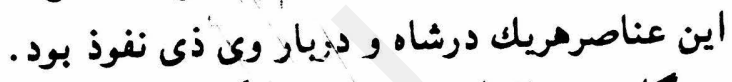

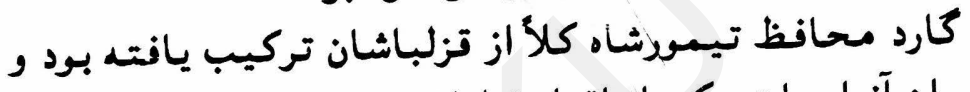

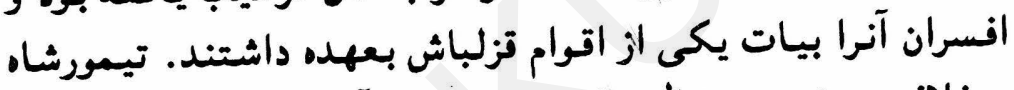

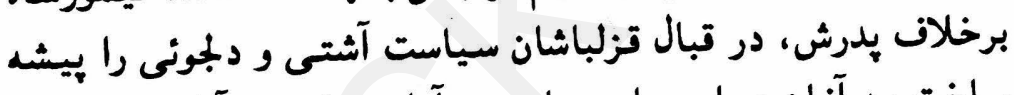

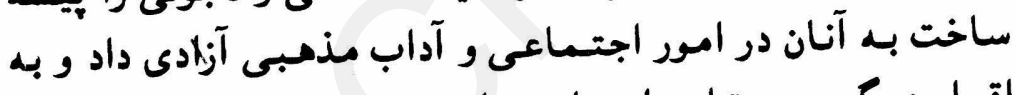

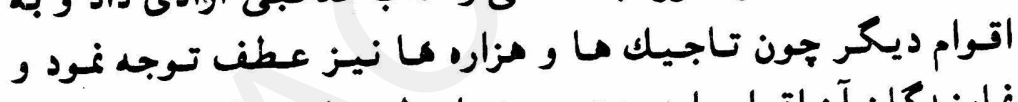

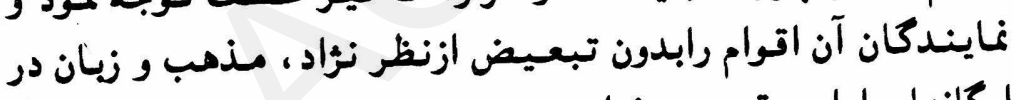

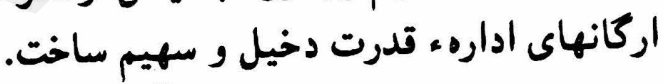

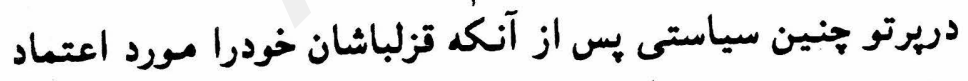

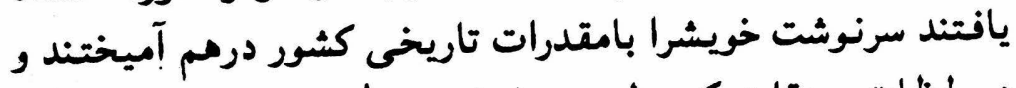

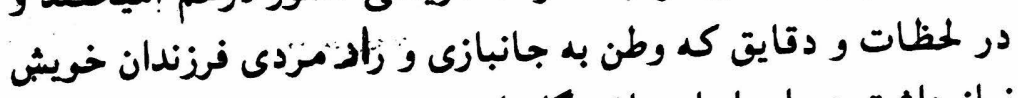

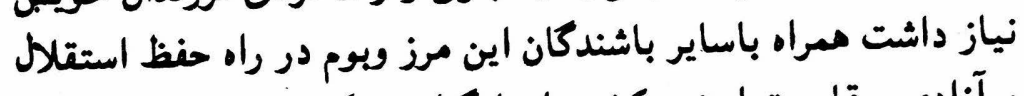

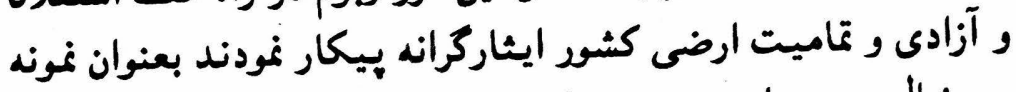

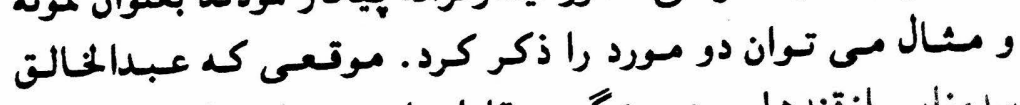

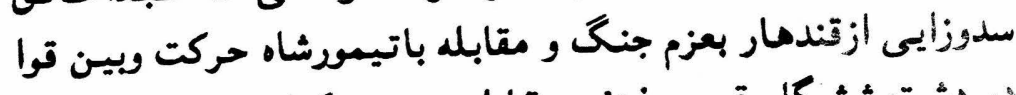

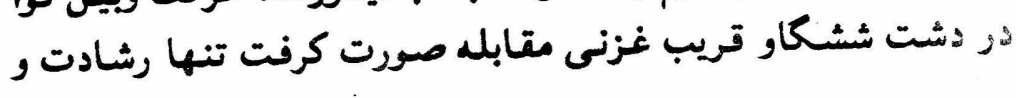


خايدارى تزلبـاشان و مزاره ما بود كه موجب شكسـت عبدالخالق كرديد.

بار ديكر درسال IVV4 ام موتعى كه بالاي قصر تيسمور شاه در

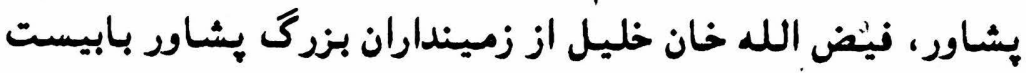

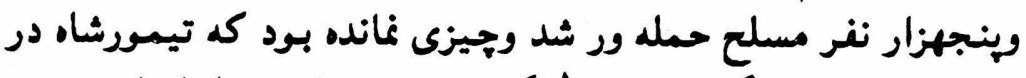

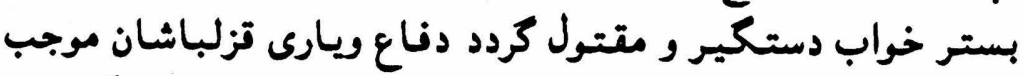

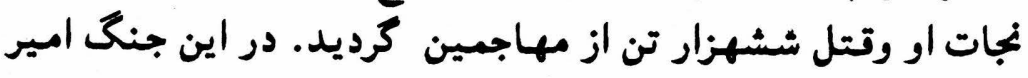

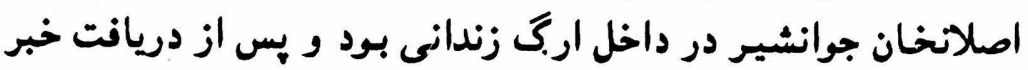

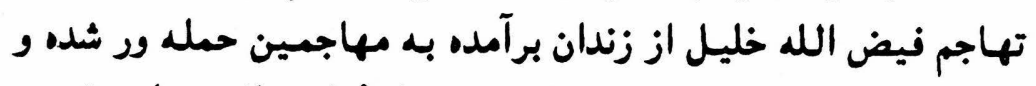

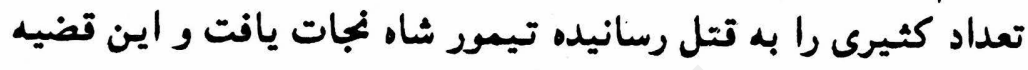

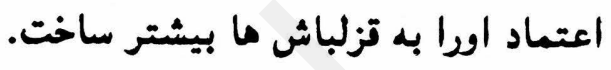

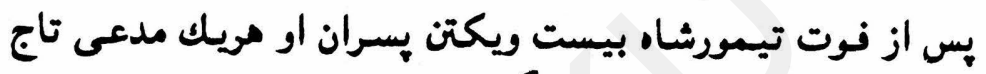

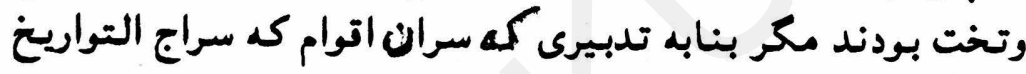

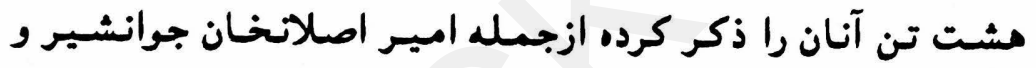

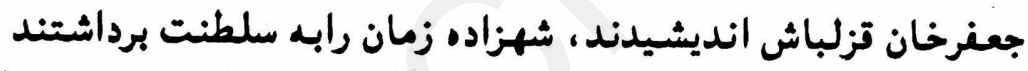

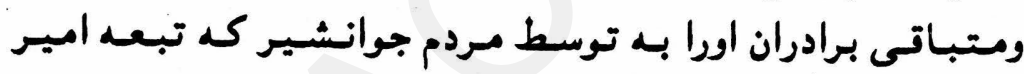

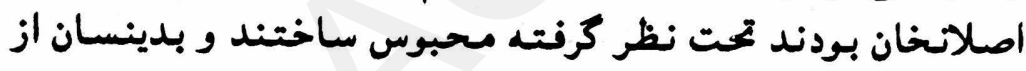

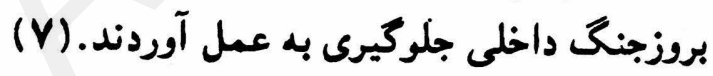

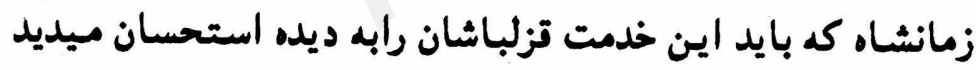

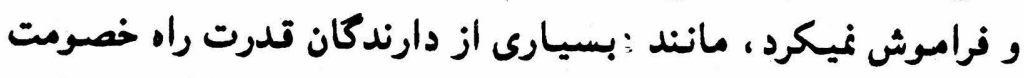

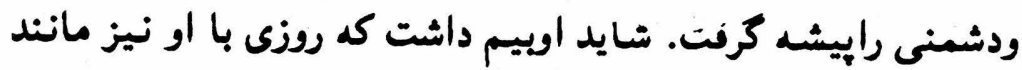

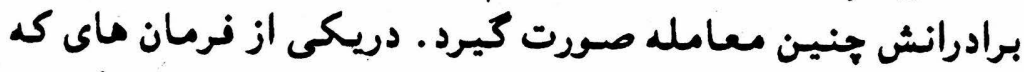

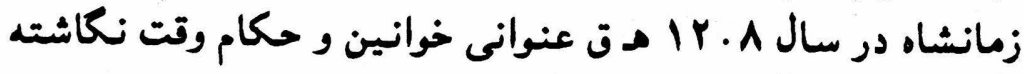

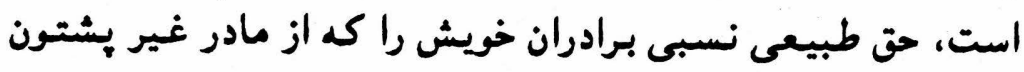

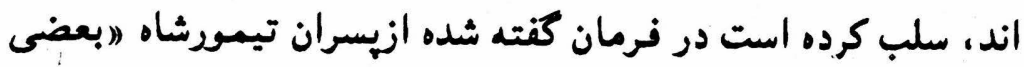

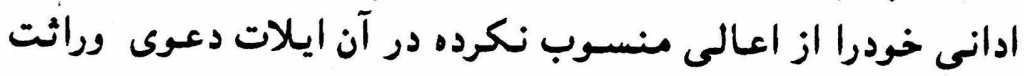


سلطان جنت مكان ننمايند ") اين "ادانى) آن بسران تيمورشاه اند كد

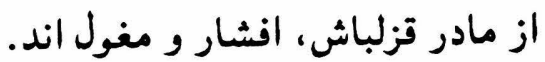

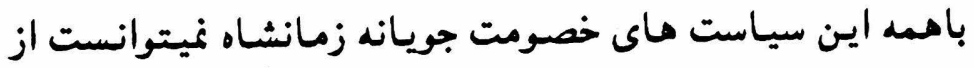

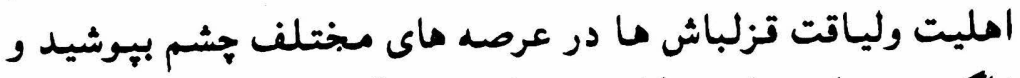

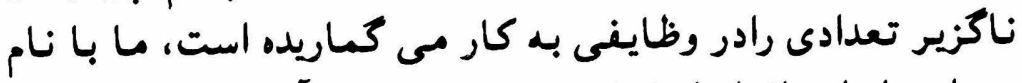

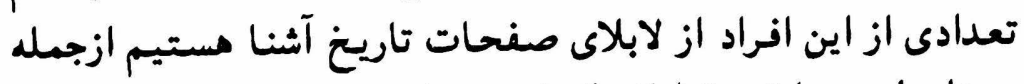

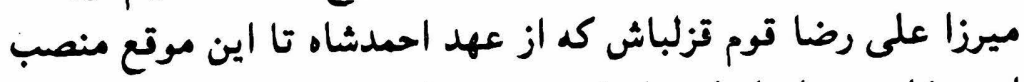

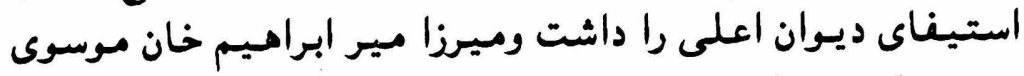

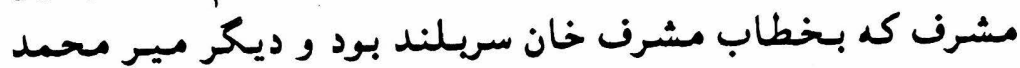

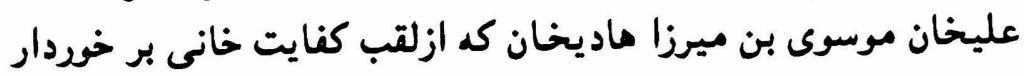

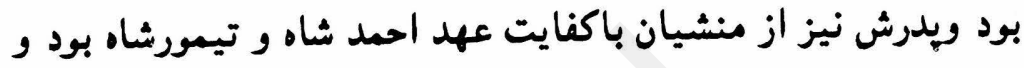

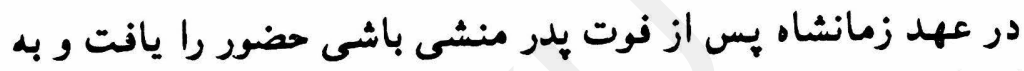

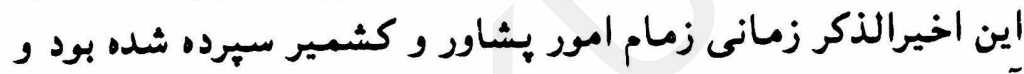

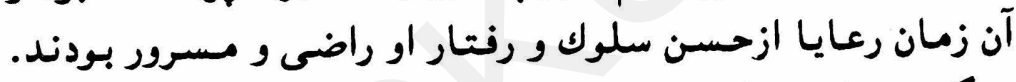

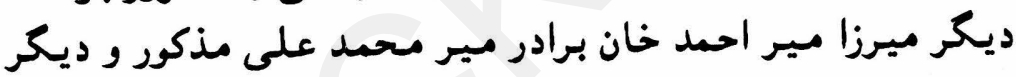

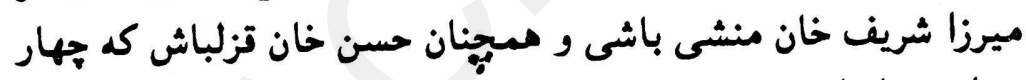

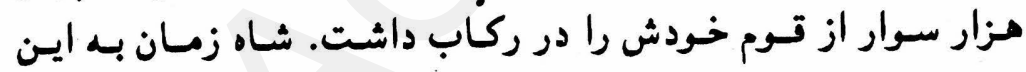

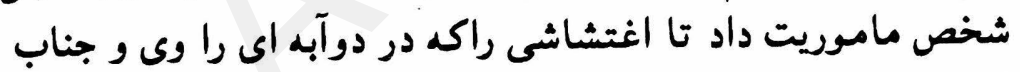

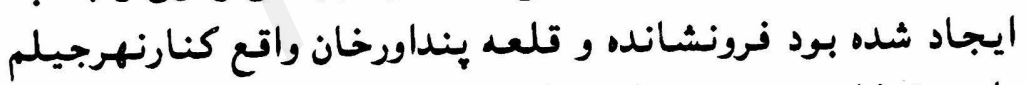

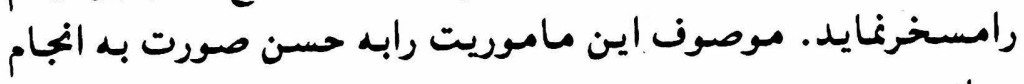
رسانيد.

زمانشاه در تشكيلات نظامى خويش نيز مرسوم بدر و جد خودرا

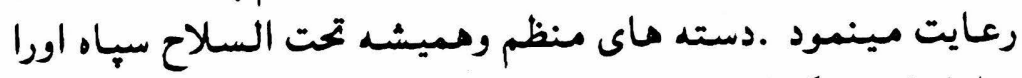

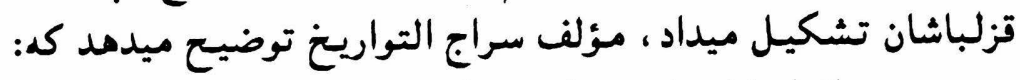

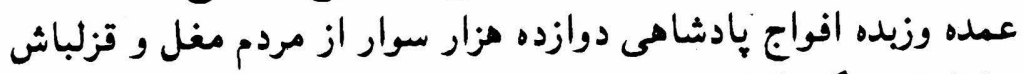

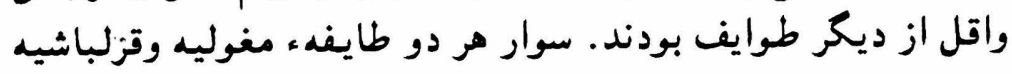


در تحت رايات نورمحمد خان امين الملك و حسن خان و صادت خان

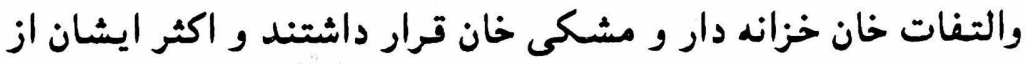

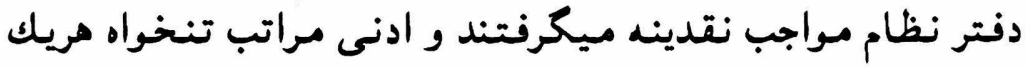

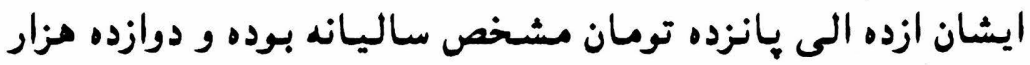

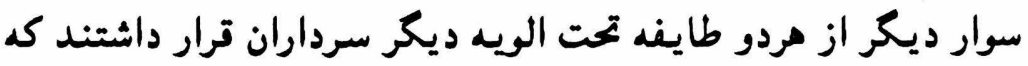

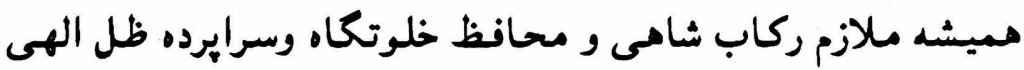

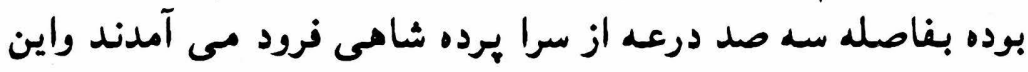

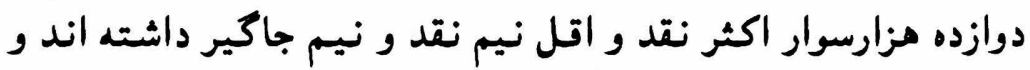

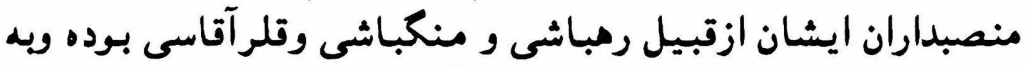

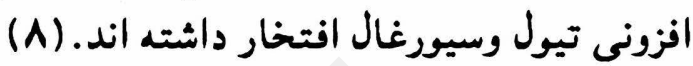

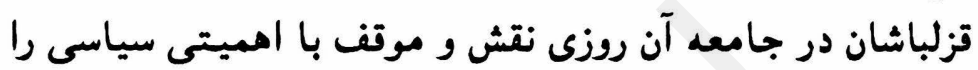

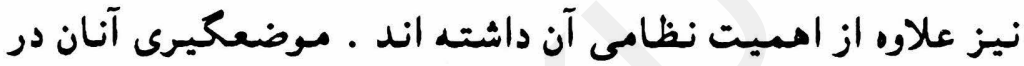

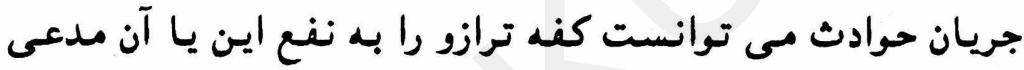

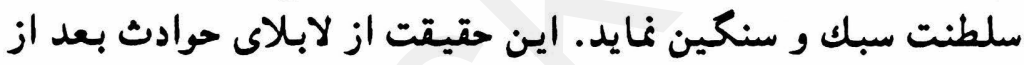

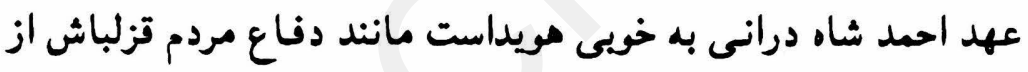

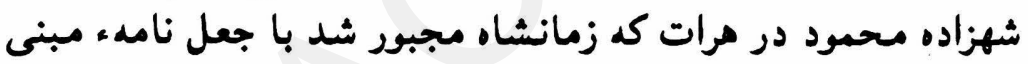

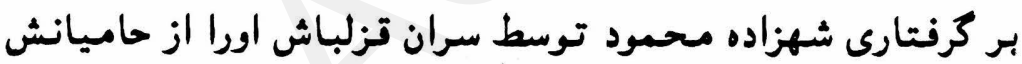

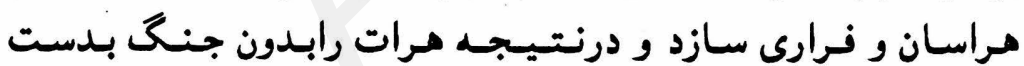

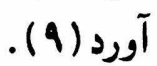

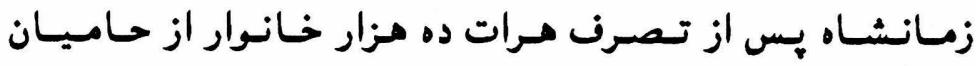

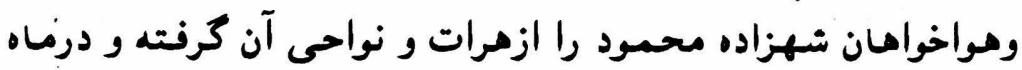

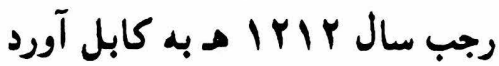

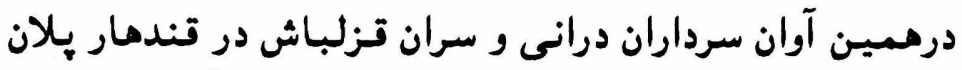

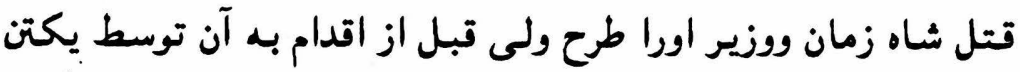

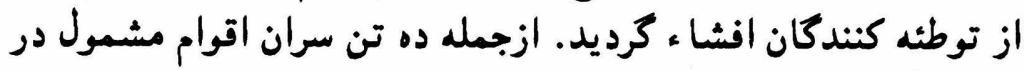

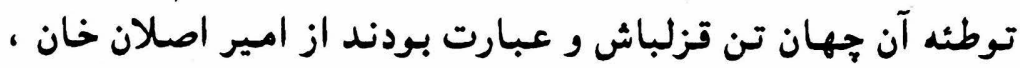


جعفرعلى خان جوانشير، يوسف على خان خواجه سرا و ميرزاشريف

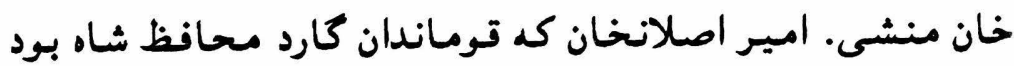

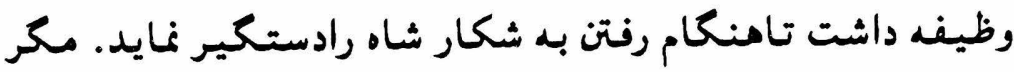

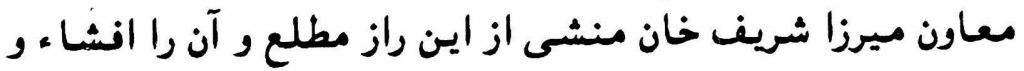

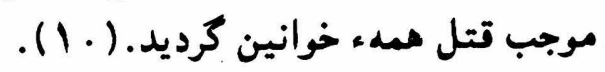

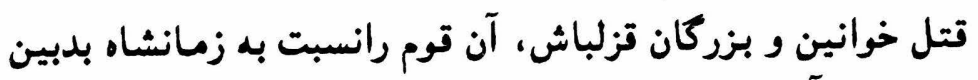

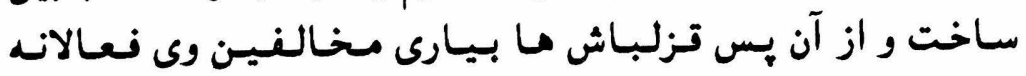

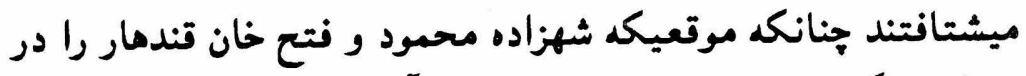

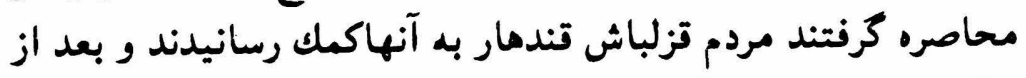

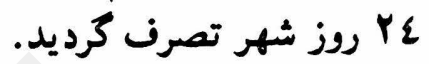

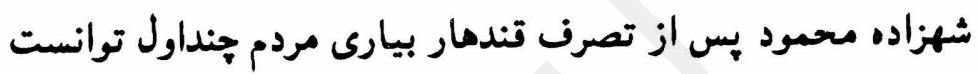

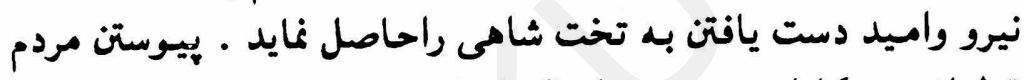

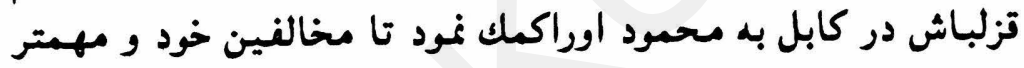

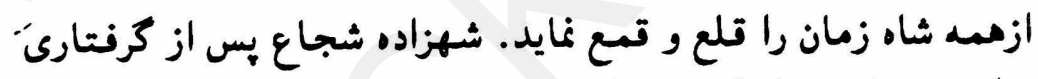

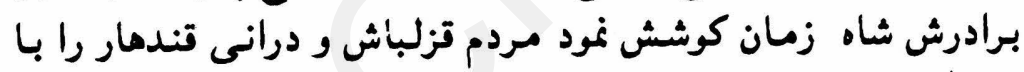

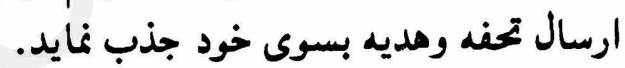

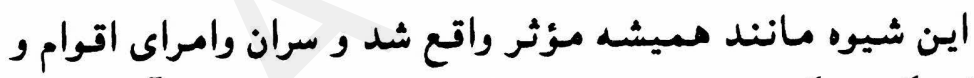

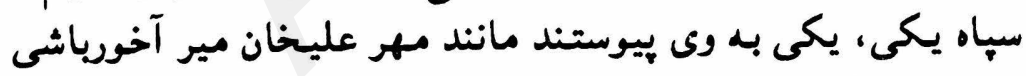

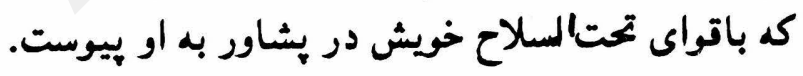

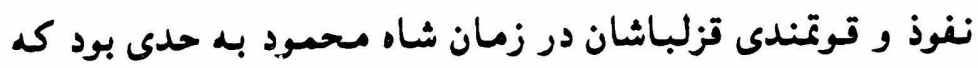

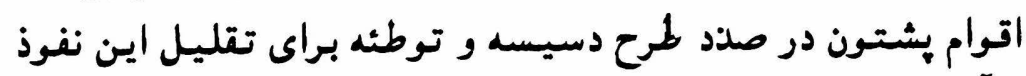

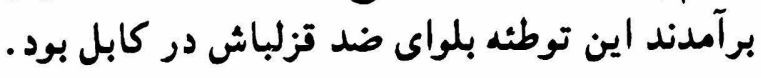

توطئه ضد قزلباشان

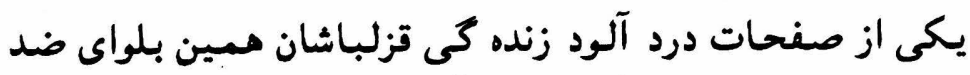

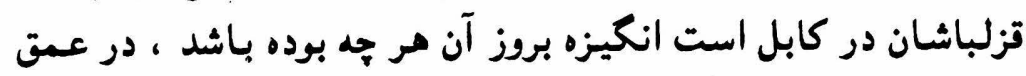


جنگ فئودال ها و خوانين عليه سلطنت و براى رمائى خود از تسلط

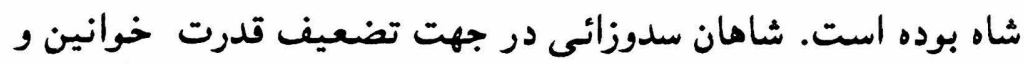

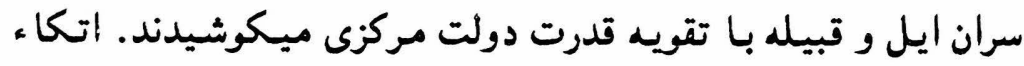

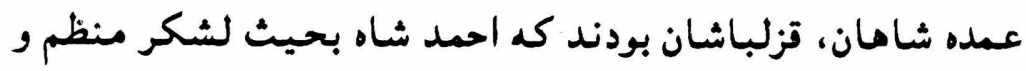

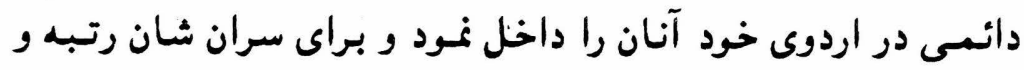

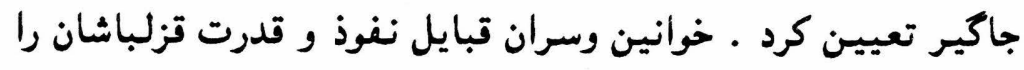

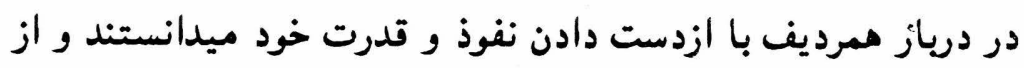

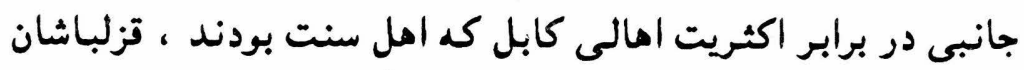

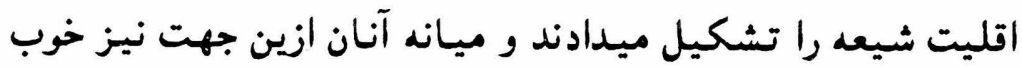

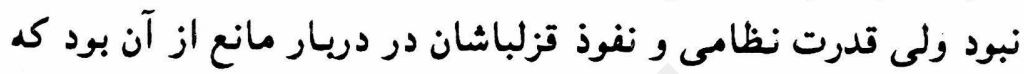
اكثريت مخالفت خود را علنى سازد.

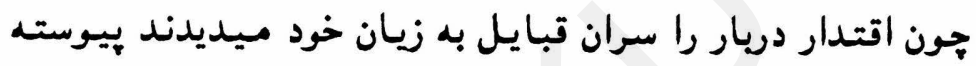

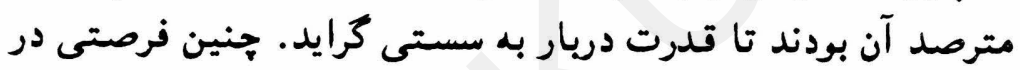

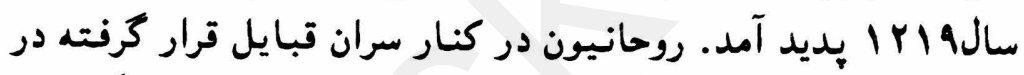

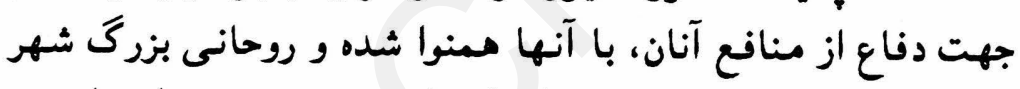

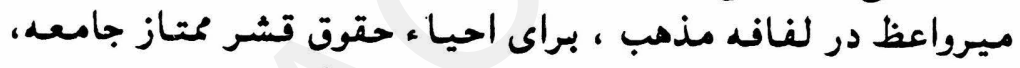

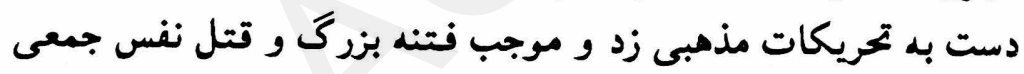

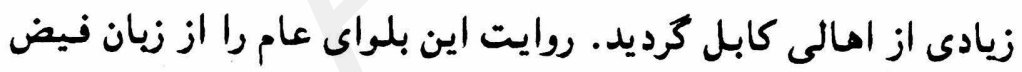

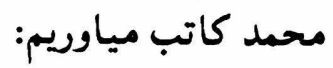

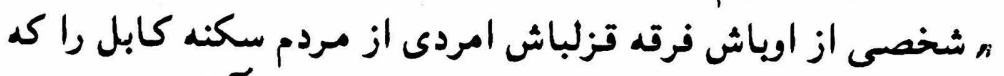

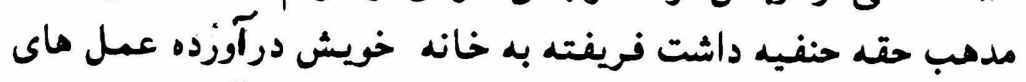

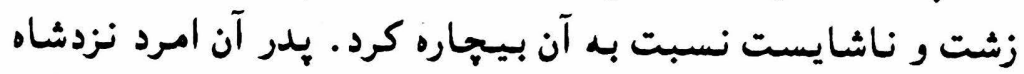

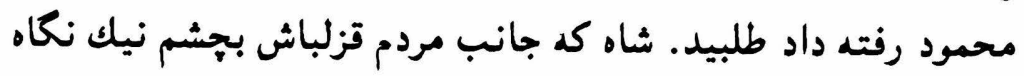

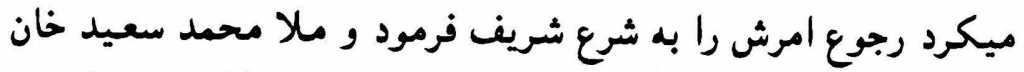

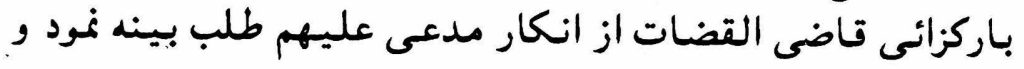

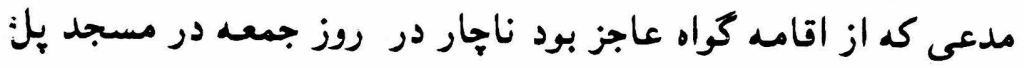




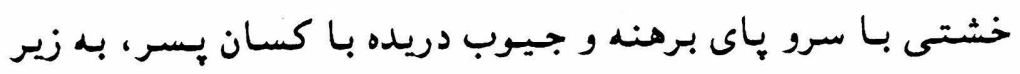

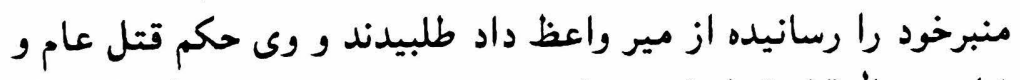

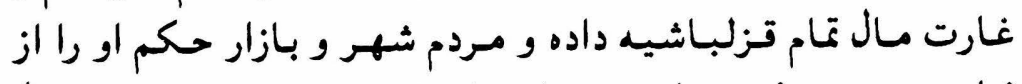

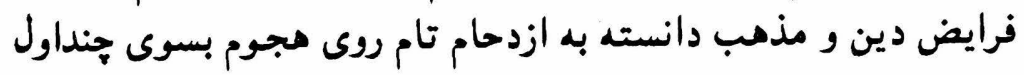

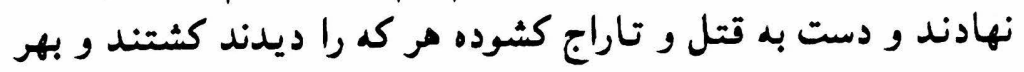

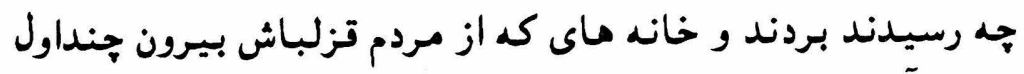

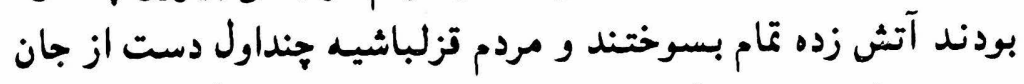

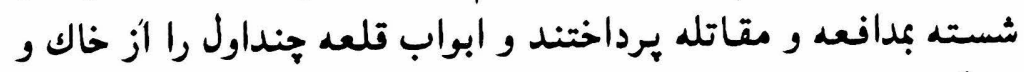

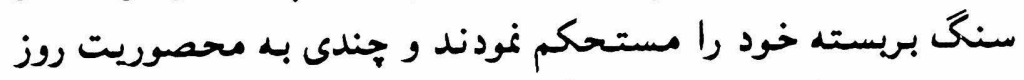

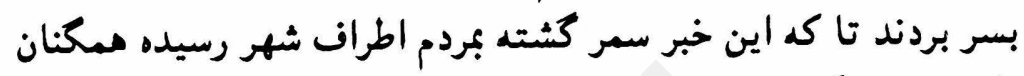

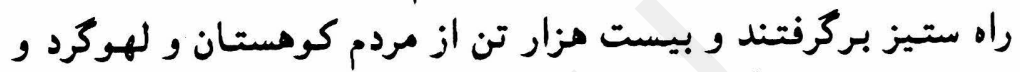

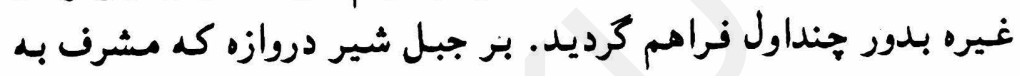

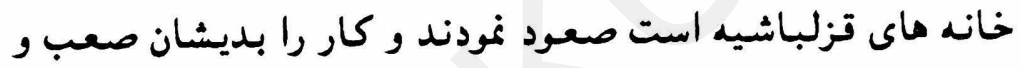

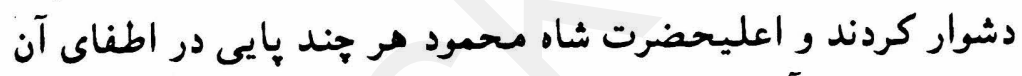

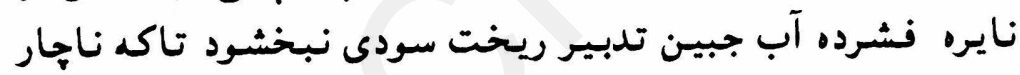

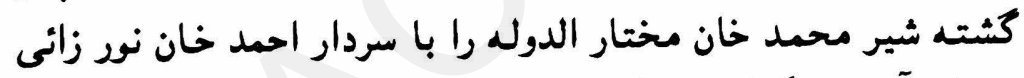

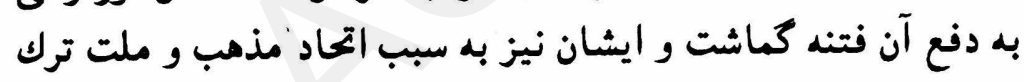

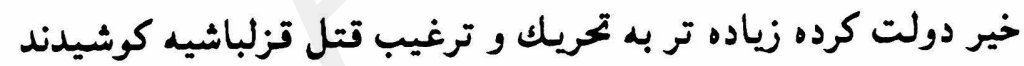

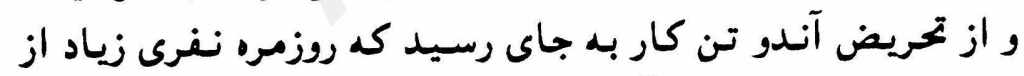

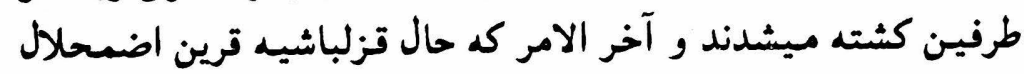

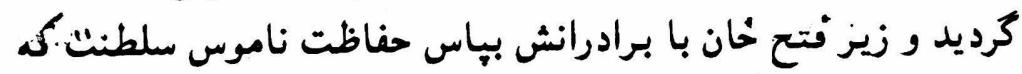

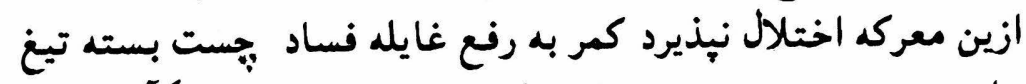

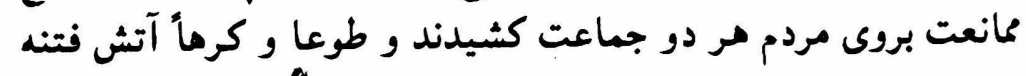

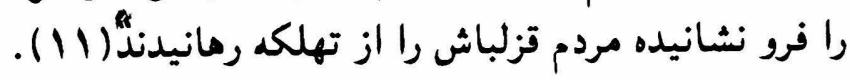

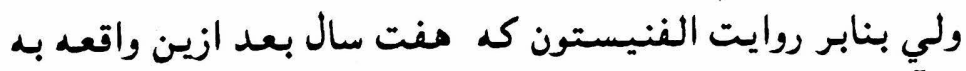

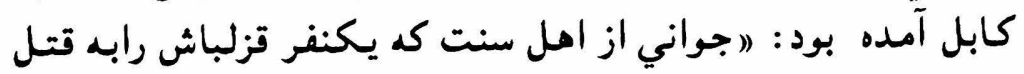




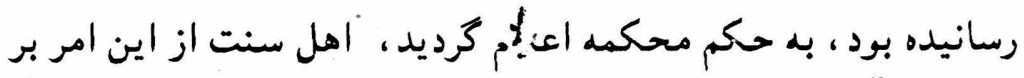

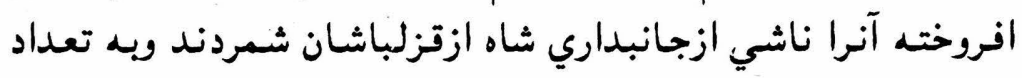

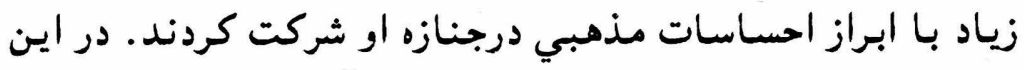

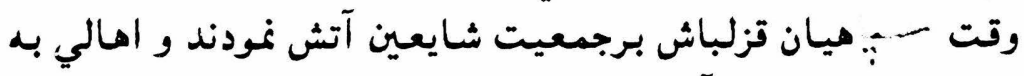

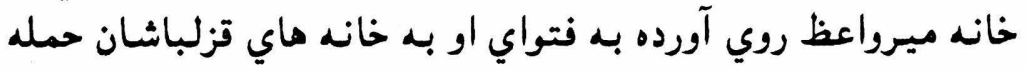
بردند ).

علت حادثه مر جه بود بدين ترتيب يك مسأله جزئى به يك فتئه

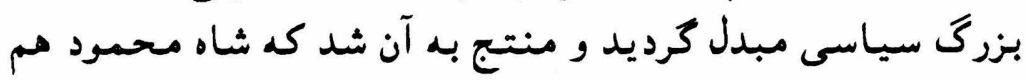

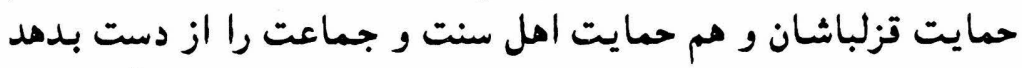

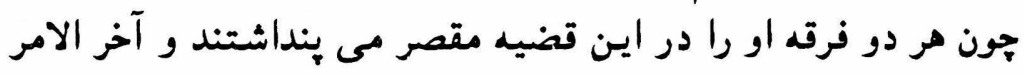

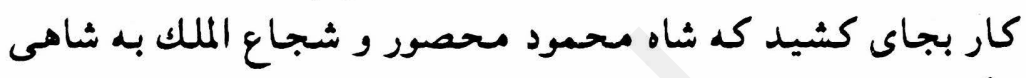
برگزيده شد.

\section{قزلباشان در موازنه قدرت:}

در طى سال هاى بعدى در منازعه برانى كسب قدرت مر مدعى تئى

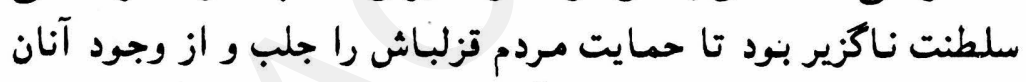

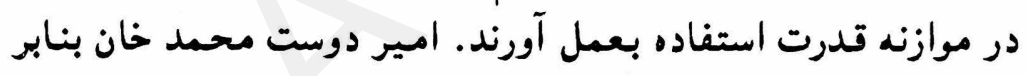

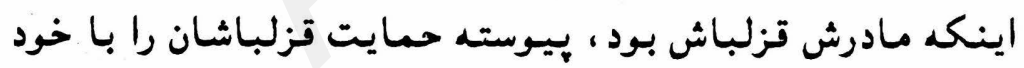

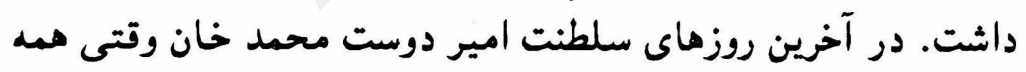

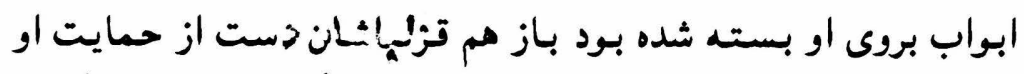

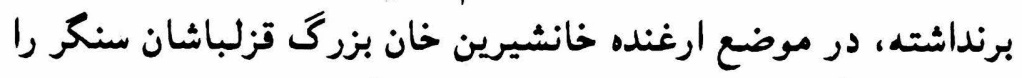

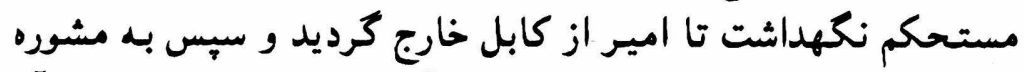

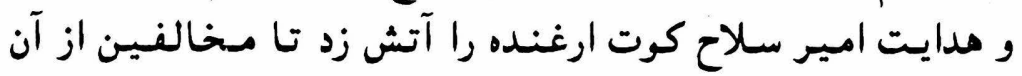

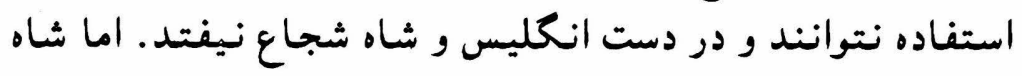

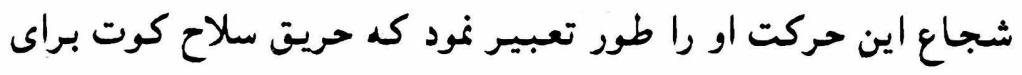




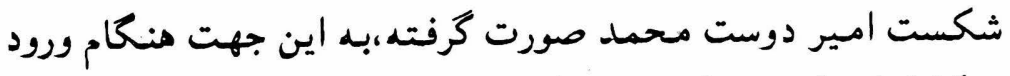

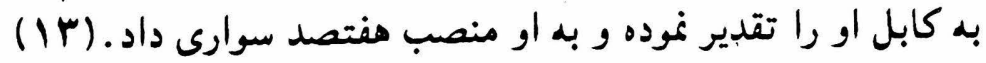

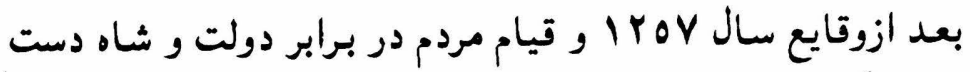

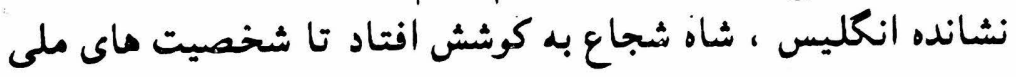

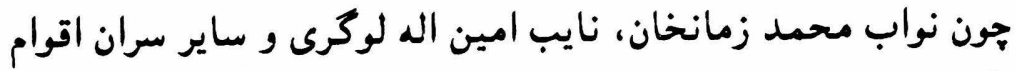

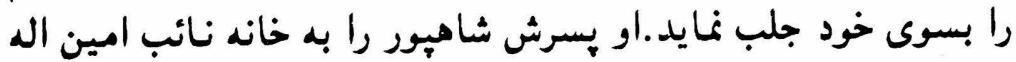

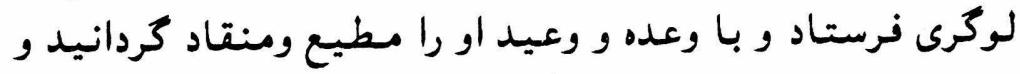

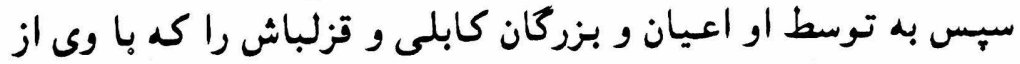

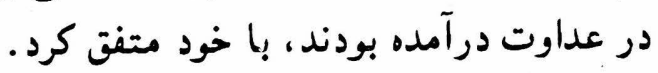

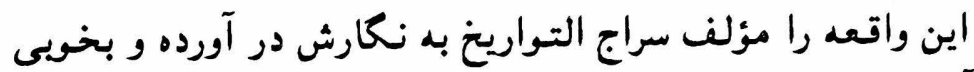

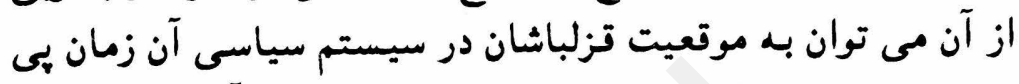

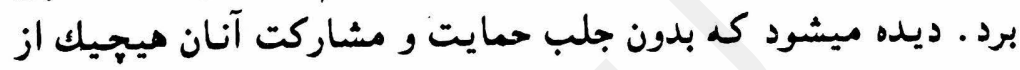

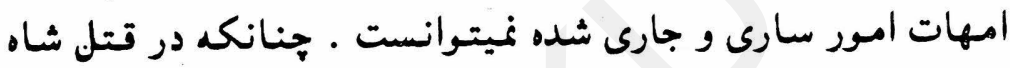

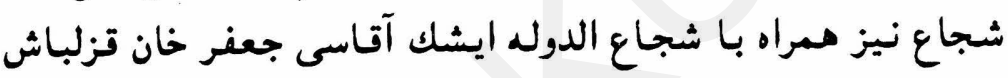

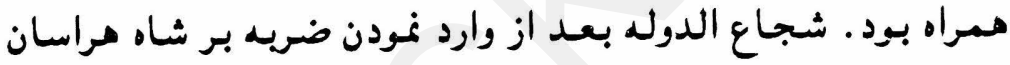

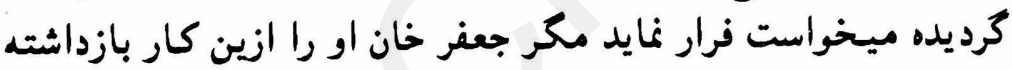

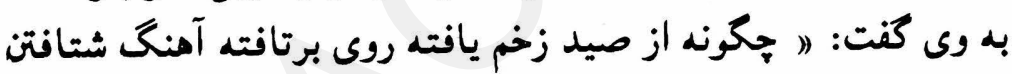

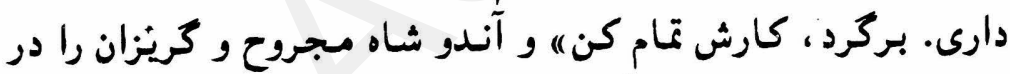

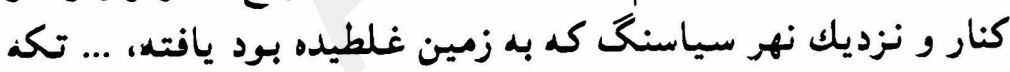

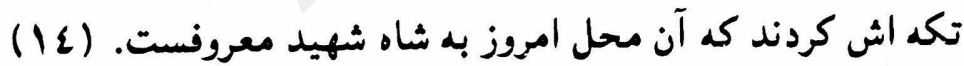

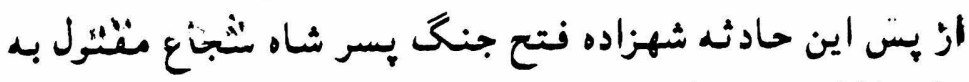

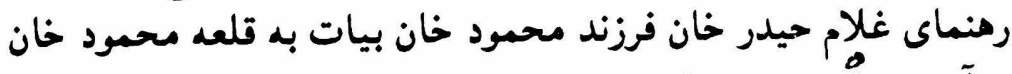

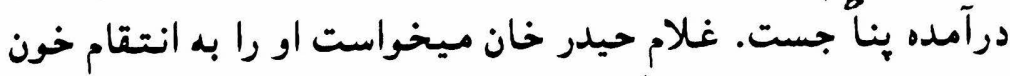

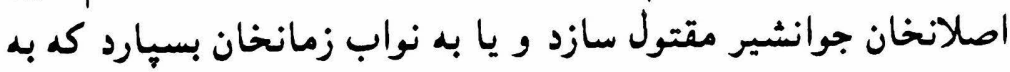

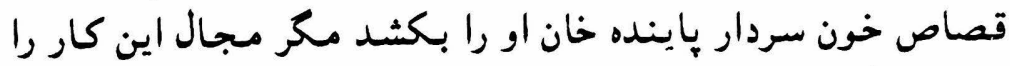

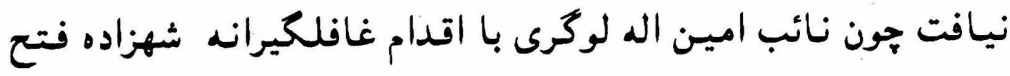


جنگ را از قلعه محمود خان كشيده با خود برد.

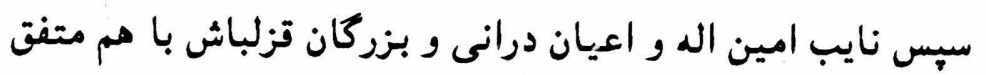

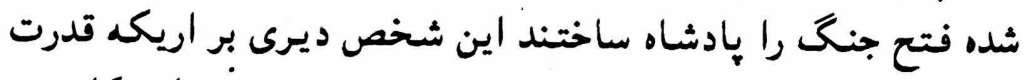

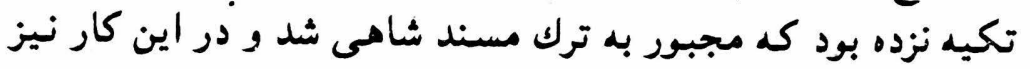

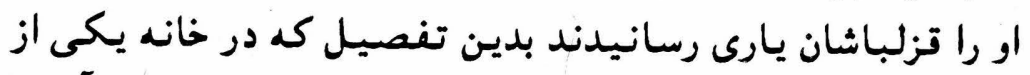

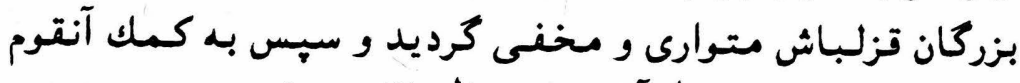

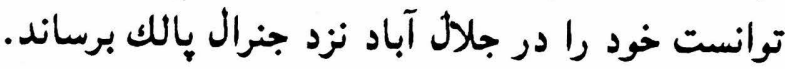

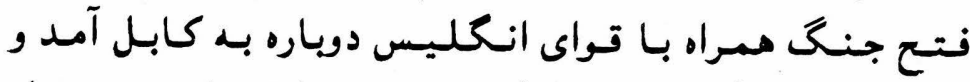

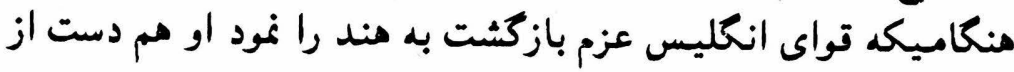

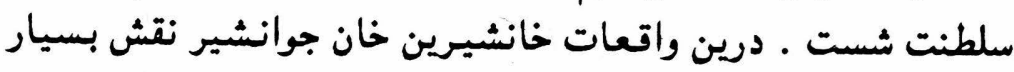

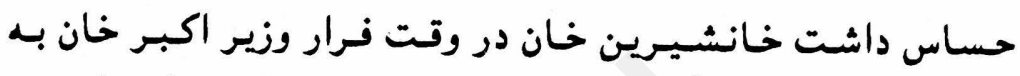

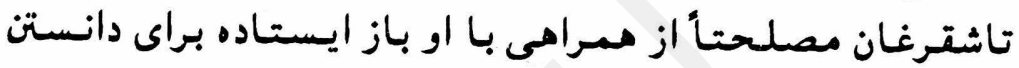

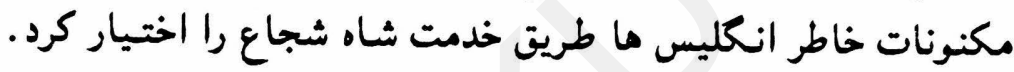

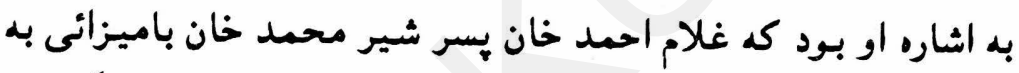

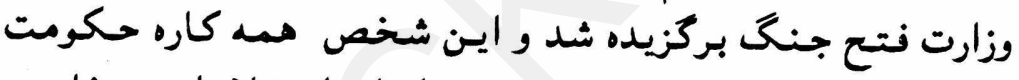

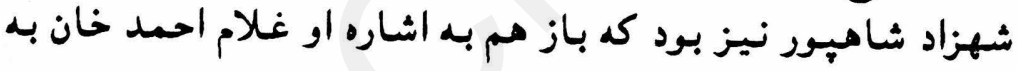

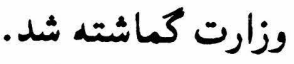

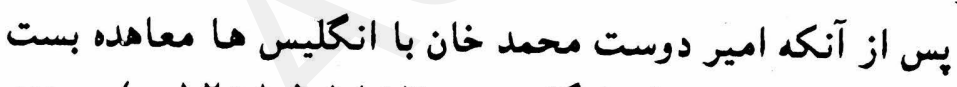

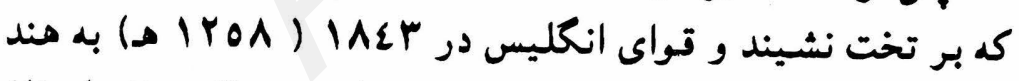

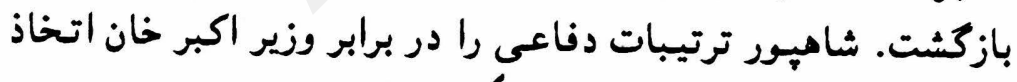

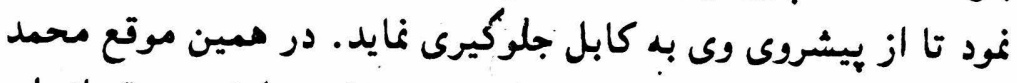

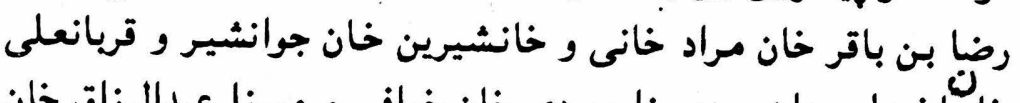

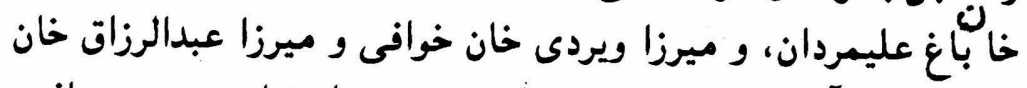

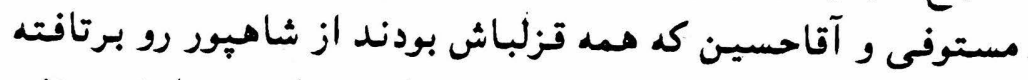

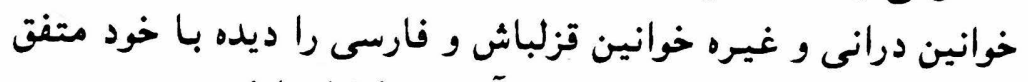

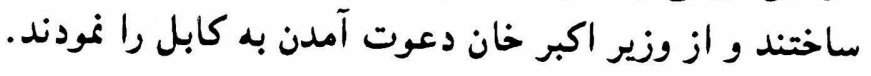

¿o 
خانشيرين خان يك شخصيت ملى و مبارز:

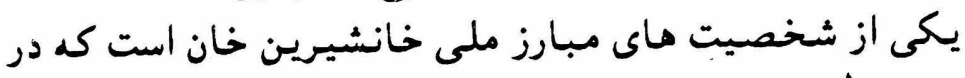

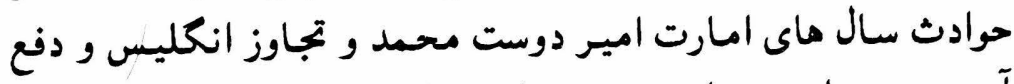

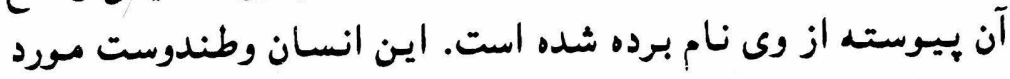

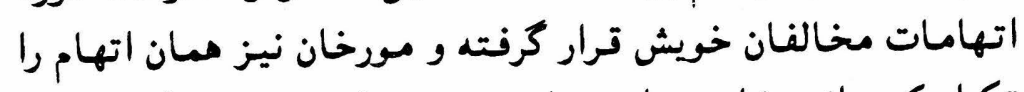

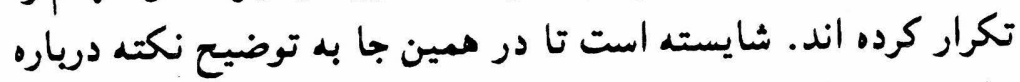

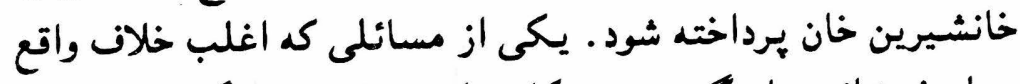

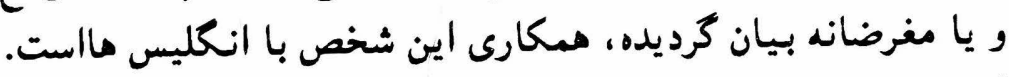

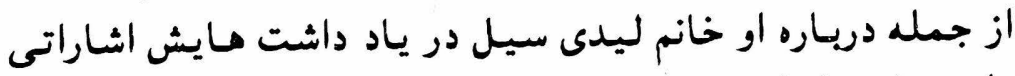

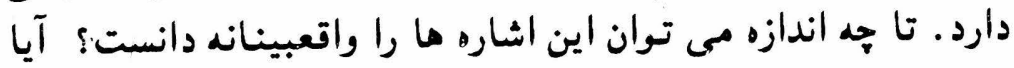

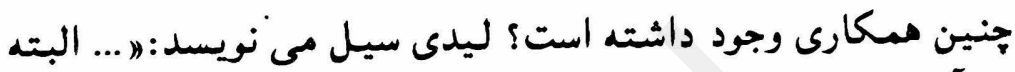

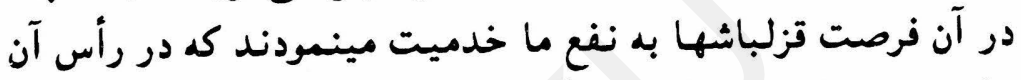

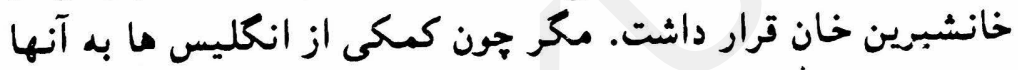

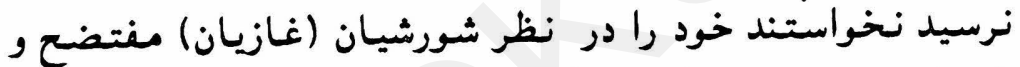

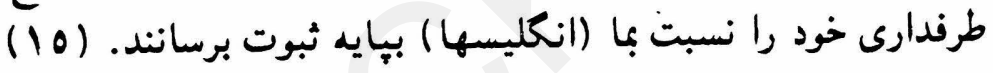

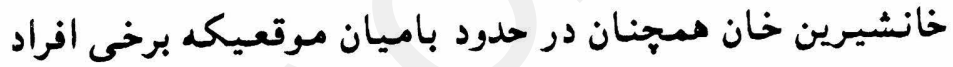

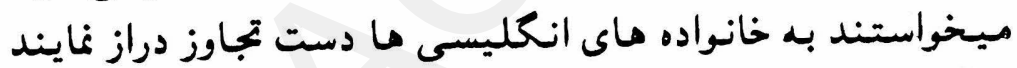

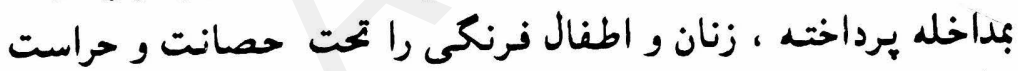

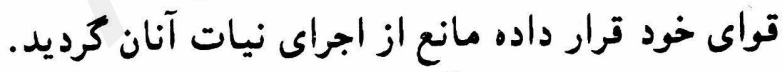

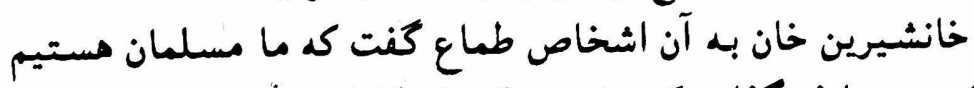

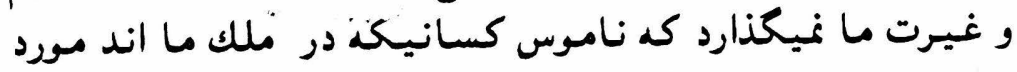

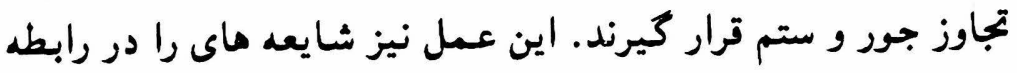

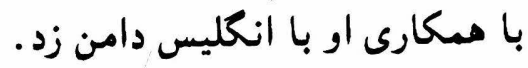

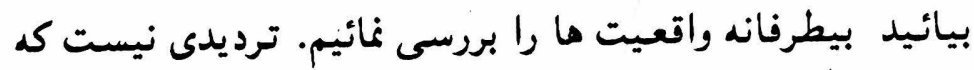

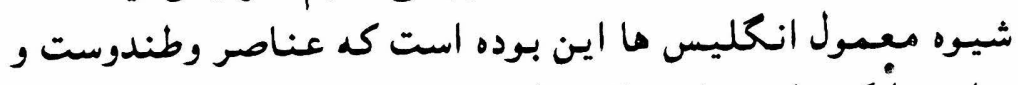

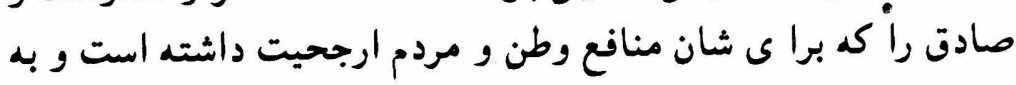




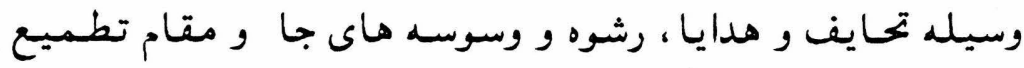

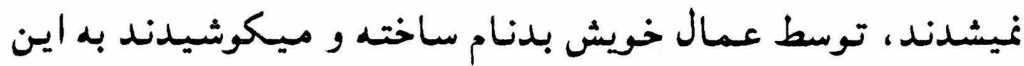

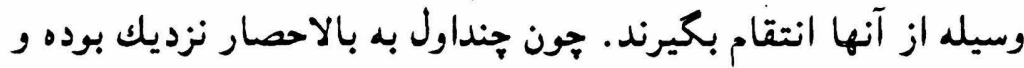

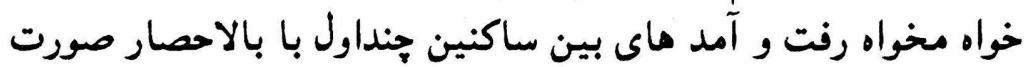

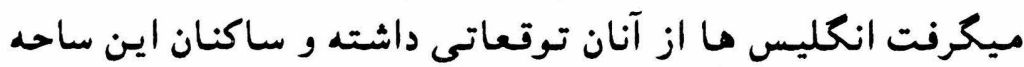

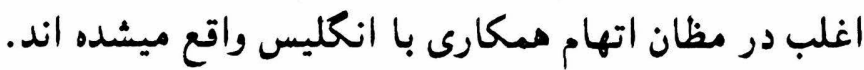

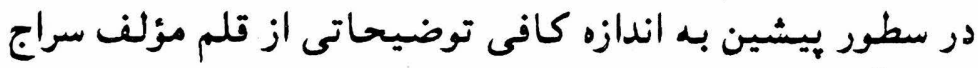

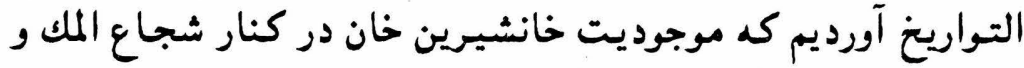

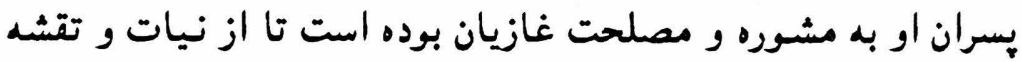

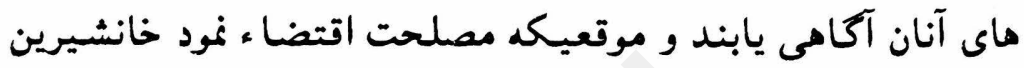

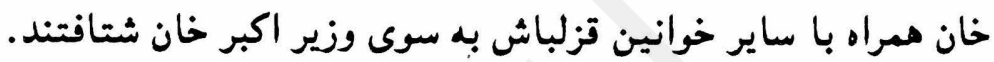

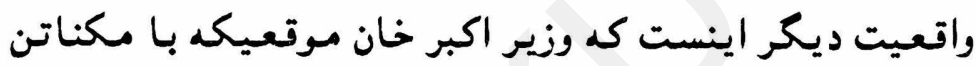

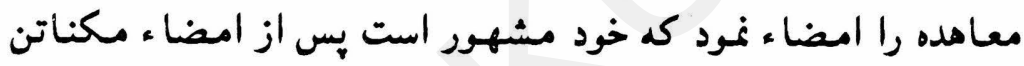

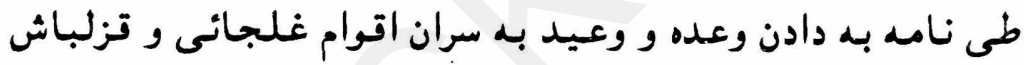

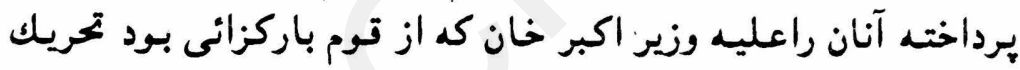

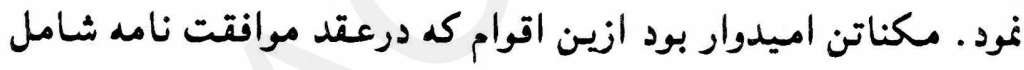

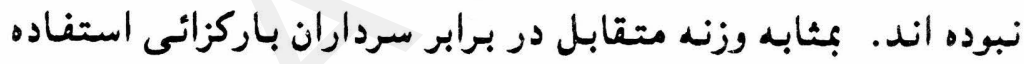

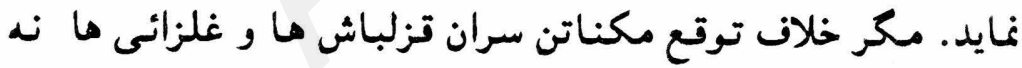

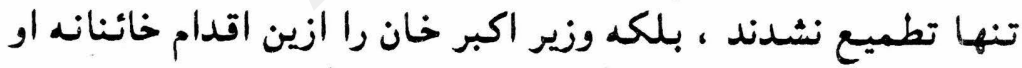

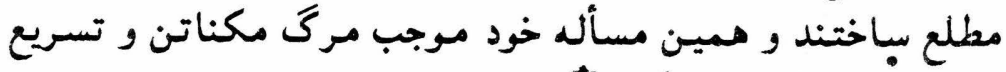
خروج قواى انكليس از كابل مكرديد.

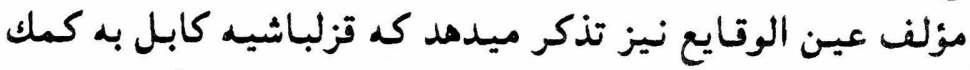

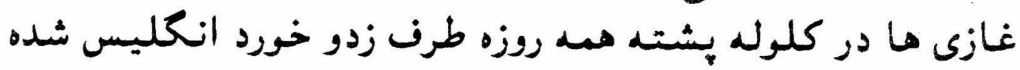

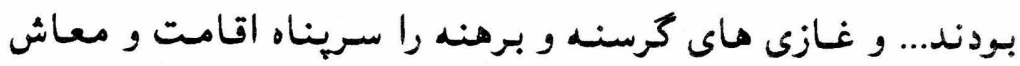
ميدأدند.

الورين رابطه مؤلف افغانستان در مسير تاريخ واقعيتى را تذكر 


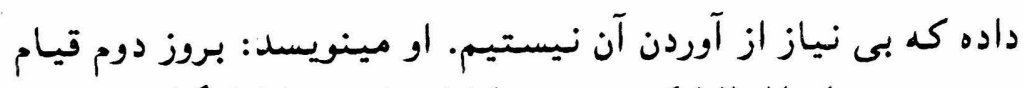

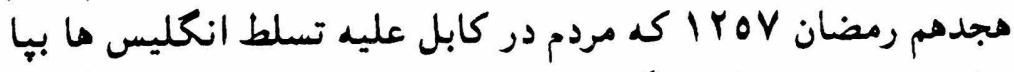

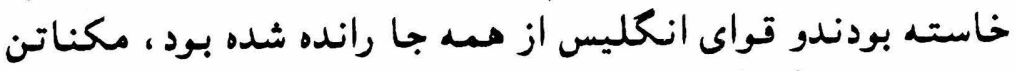

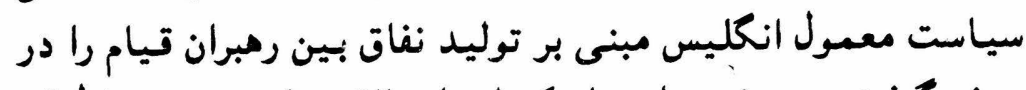

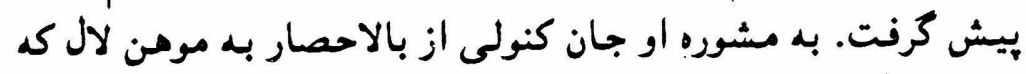

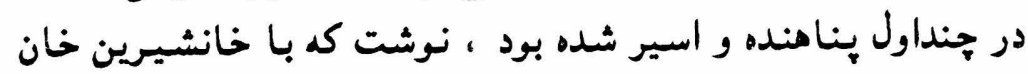

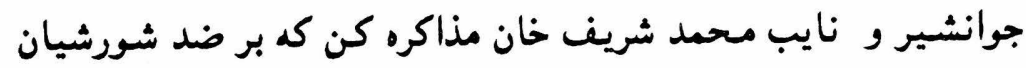

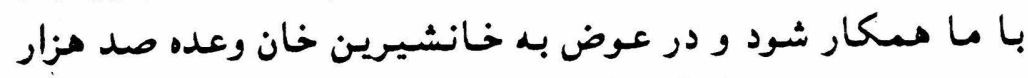

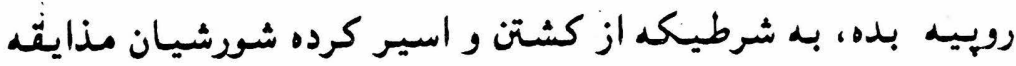

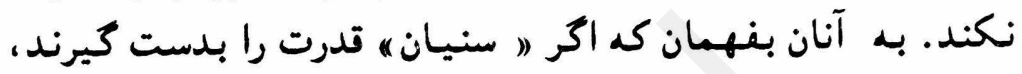

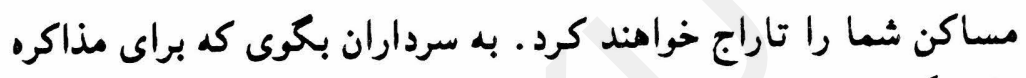

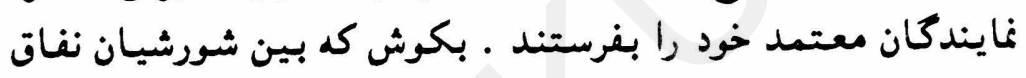

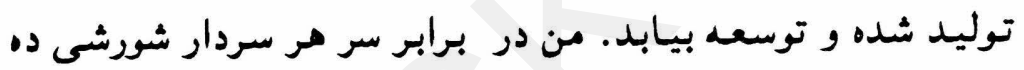

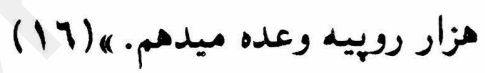

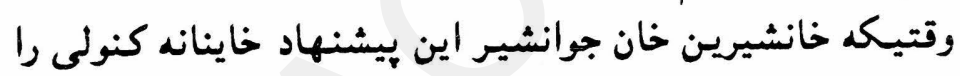

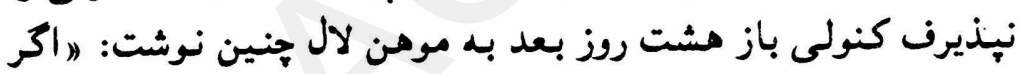

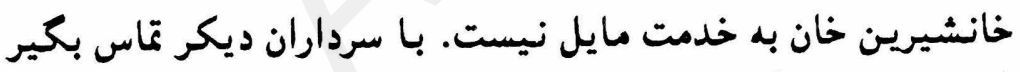

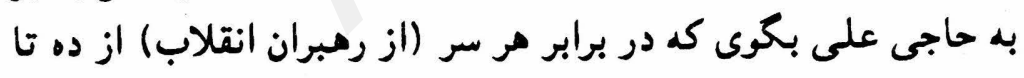

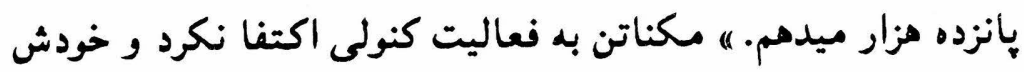

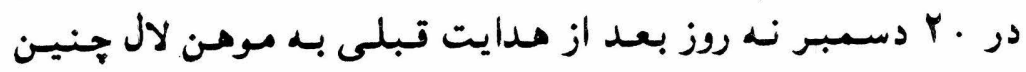

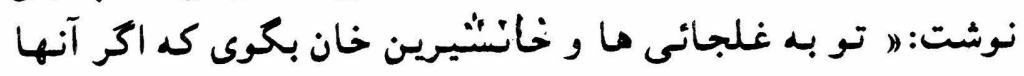

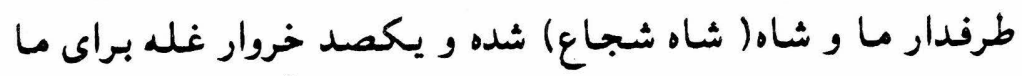

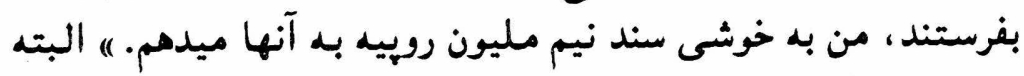

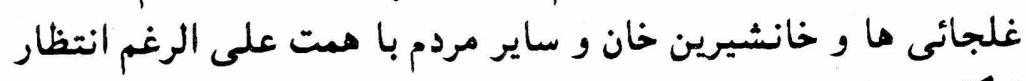

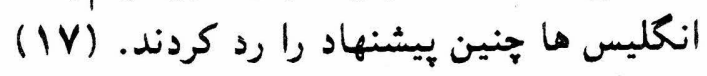

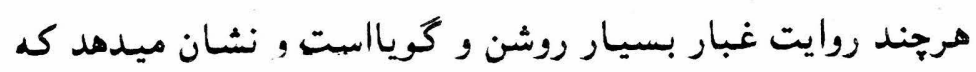




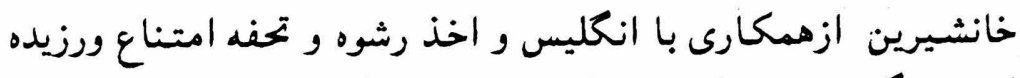

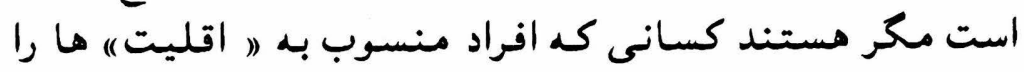

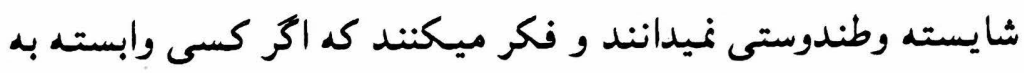

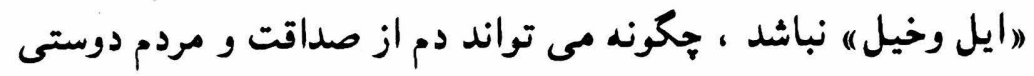
بزند.

\section{برخى دولتمردان قزلباش:}

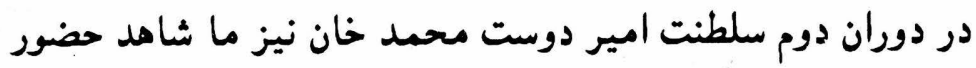

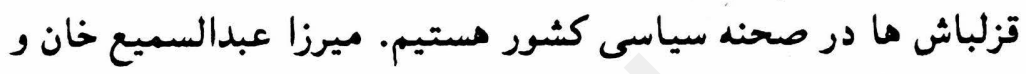

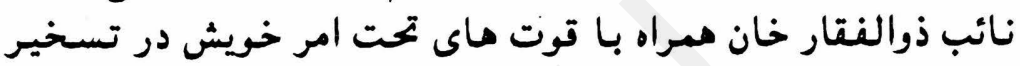

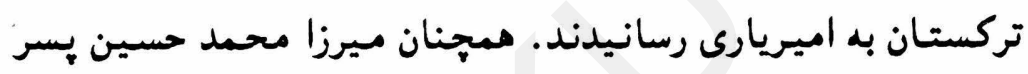

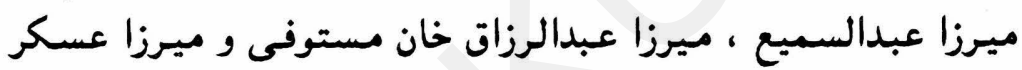

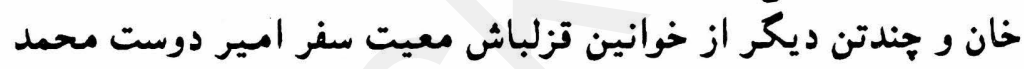

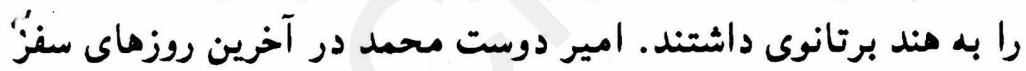

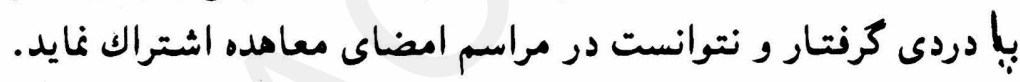

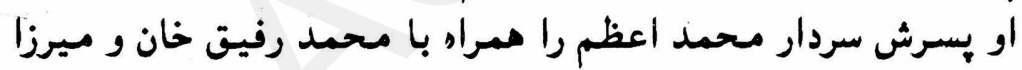

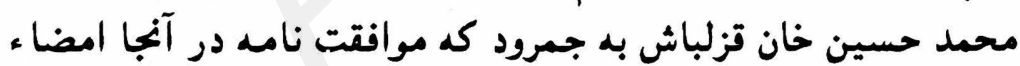

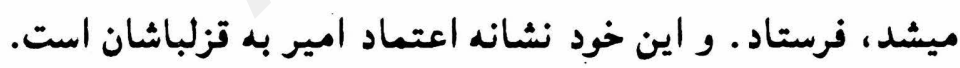

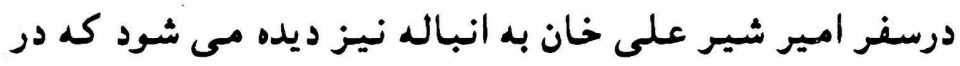

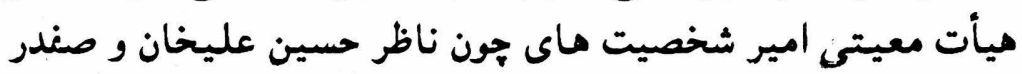

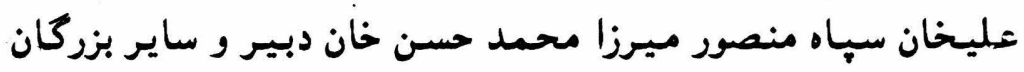
قزلباش عضويت داشتند كه در طول سفر و ملاقات ما ما امير را معراه

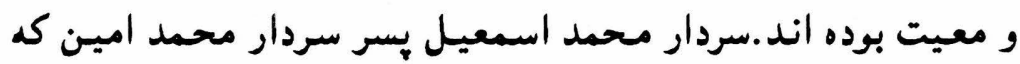

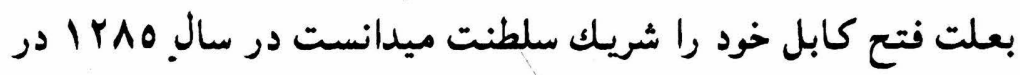

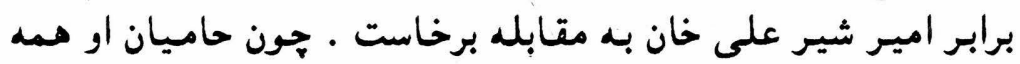

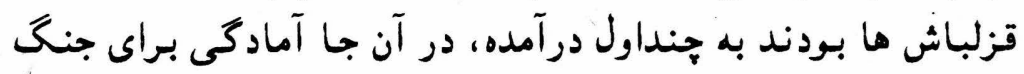


كرفت و امير شير عليخان بر كوه شير دروازه نيرو آماده كرد. قبل

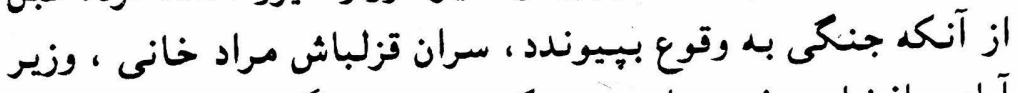

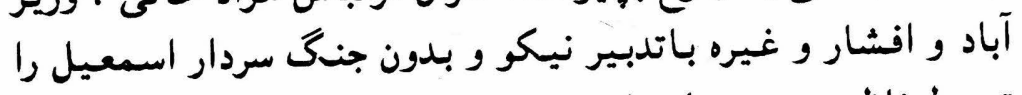

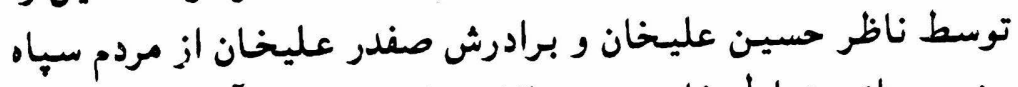

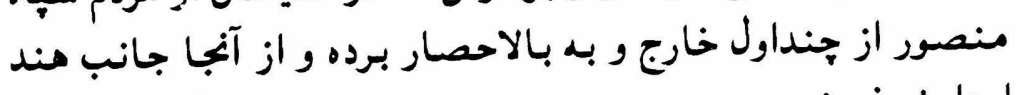
اعزامش نمودند.

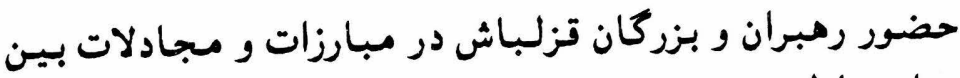

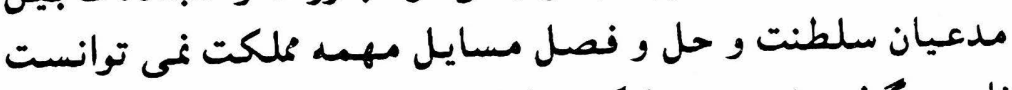

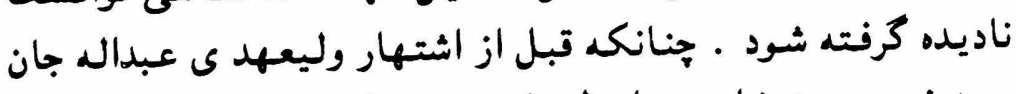

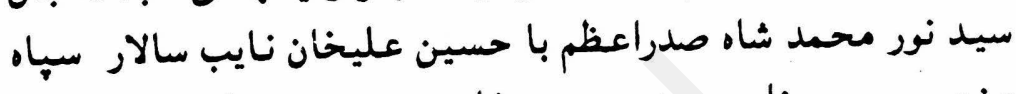

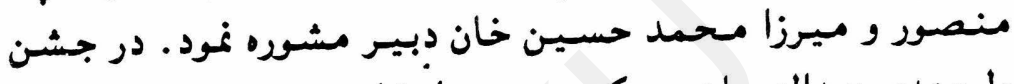

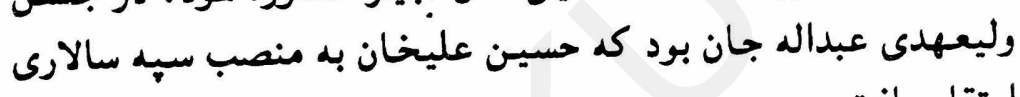
ارتقاء يافت.

در تاريخ نام تعداد زيادى از كارداران قزلباش در عهد امير شير

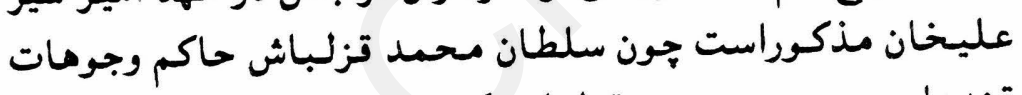

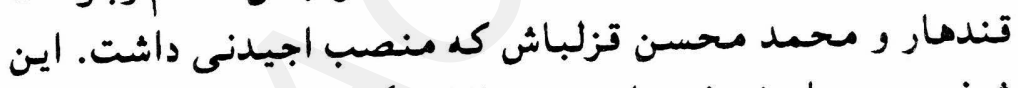

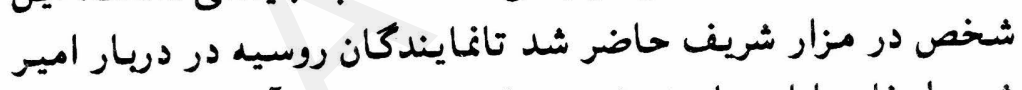

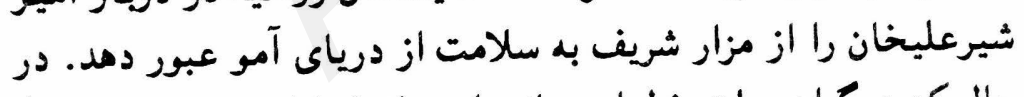

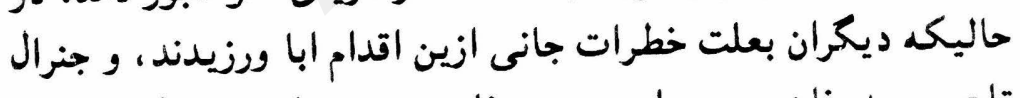

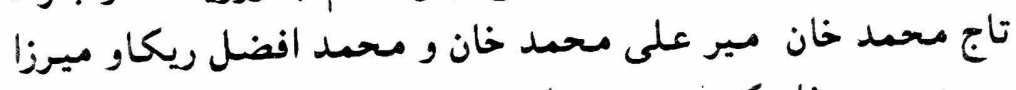

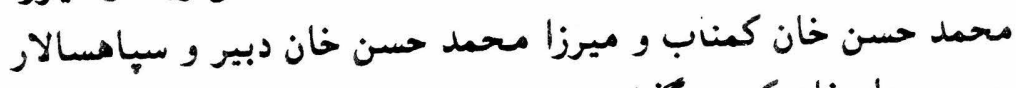

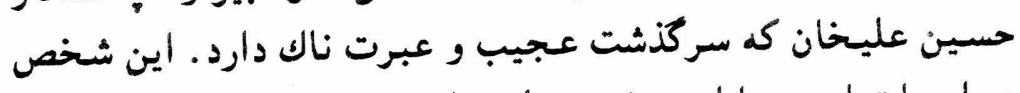

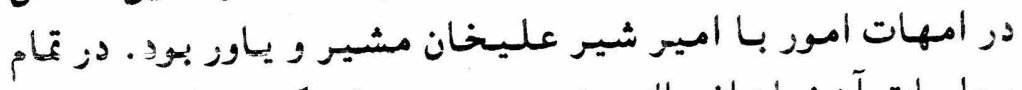

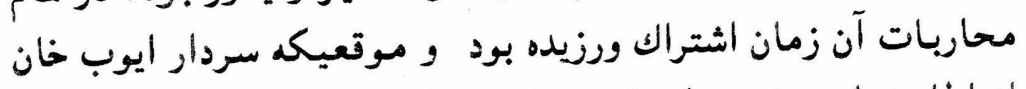

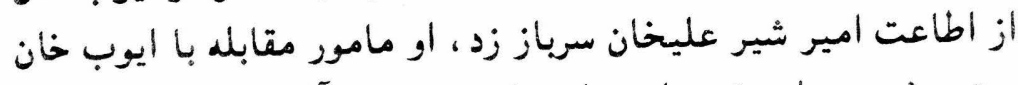

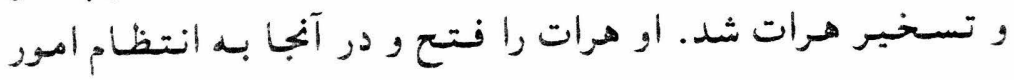


اشتغنال داشت. اين شخص نمونه از صداقت وفادارى است و منك شناسي قزلباش ما را تمثيل ميكند.

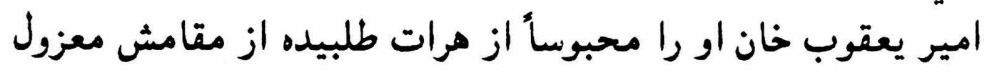

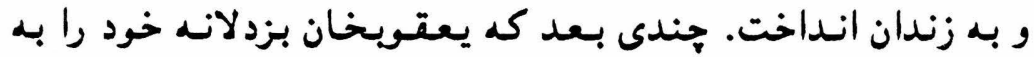

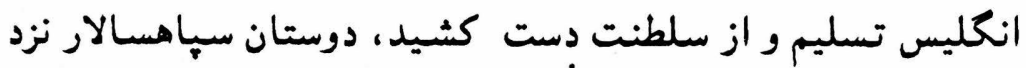

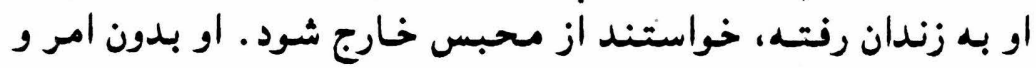

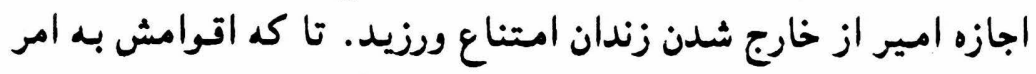

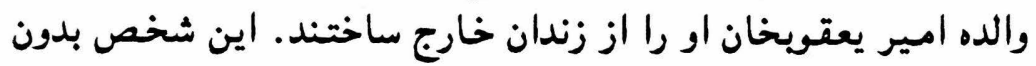

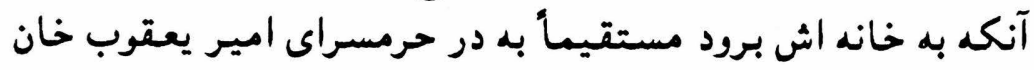

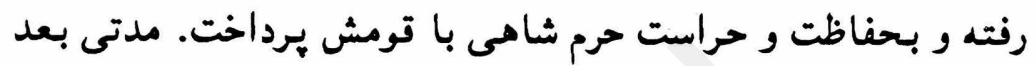

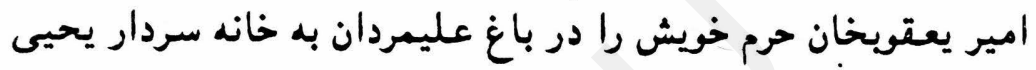

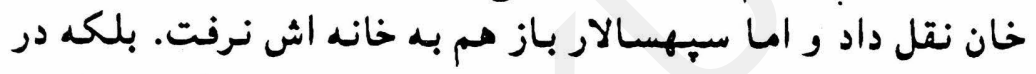

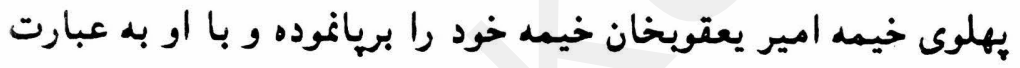

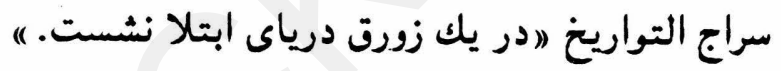

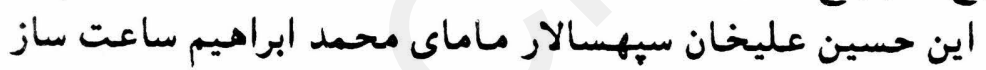

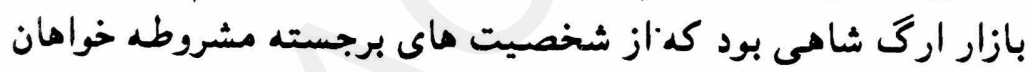

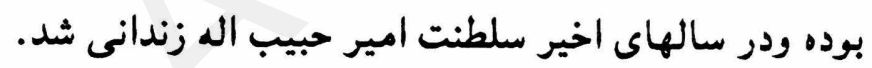

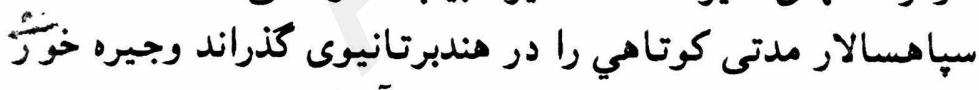

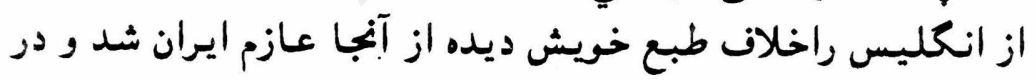

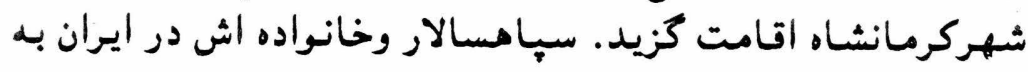

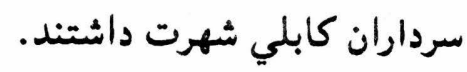

خصومت امير عبدالرحمن خان با قزلباشان:

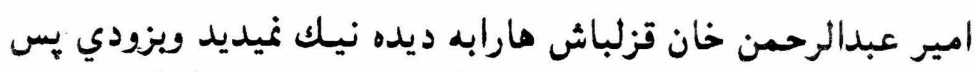

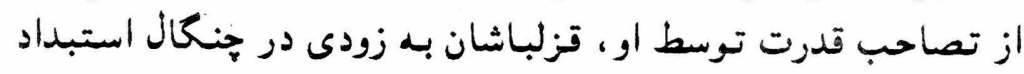

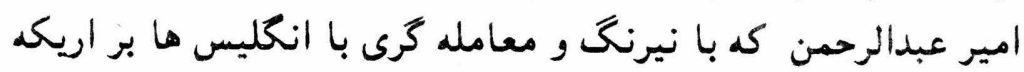


قدرت تكيه زد گرفتار آمدند آنجه امير با سران مجاهدان و غـازيان

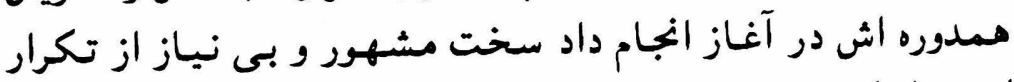

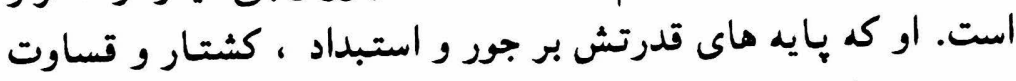

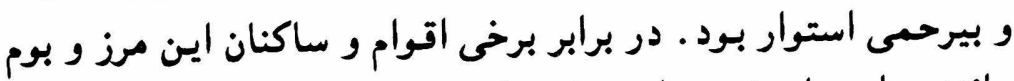

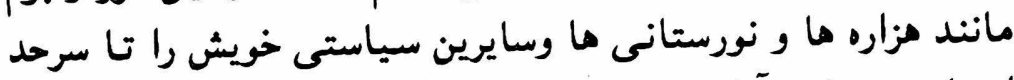

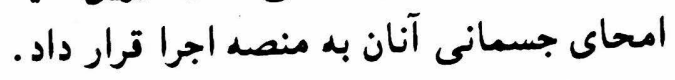

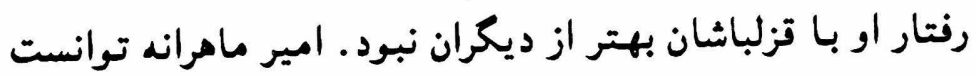

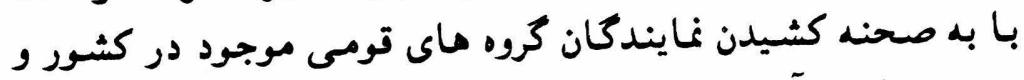

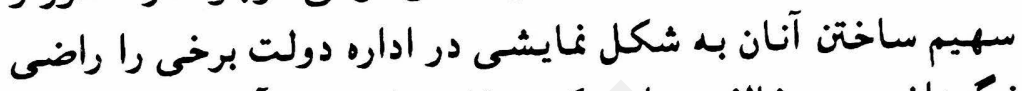

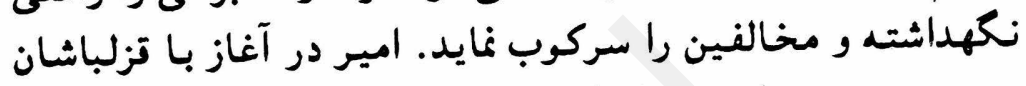

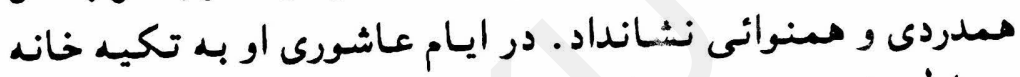

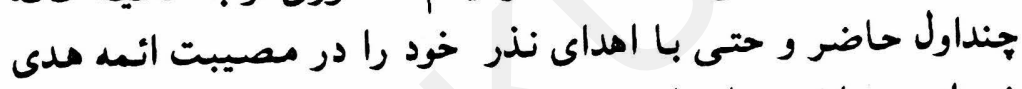

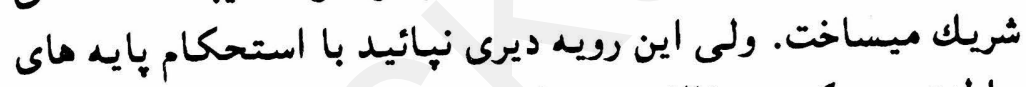

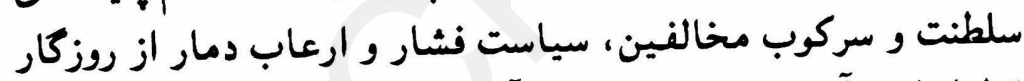

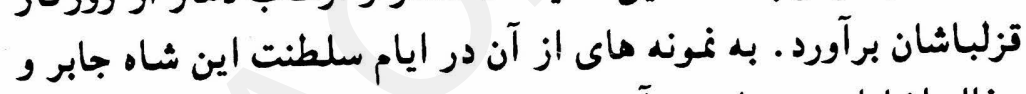
سفاك اشاراتي بعمل مى آوريم.

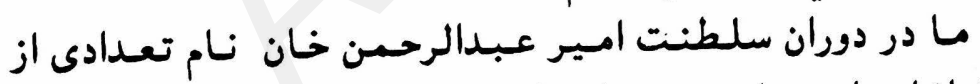

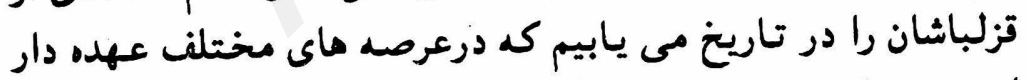
امور بوده اند.

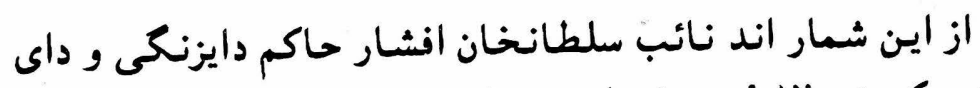

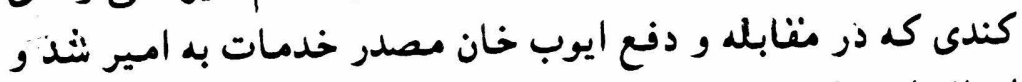

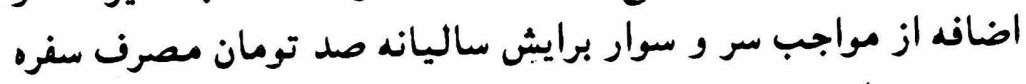

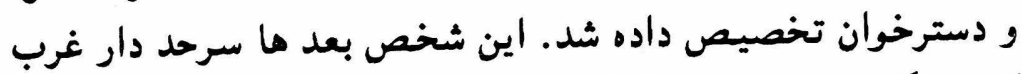

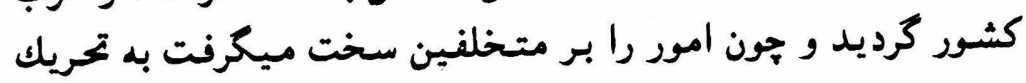

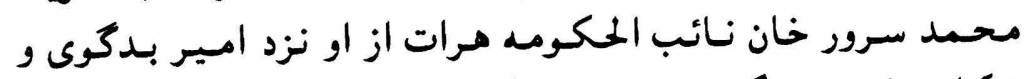

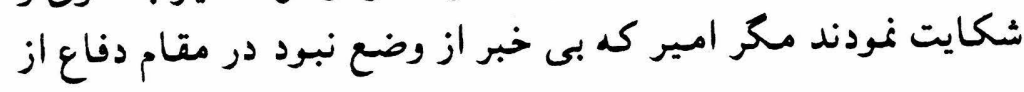


سرحددار برآمده ، در جواب شاكى كفت: قزلباشان را مغرضين بد وند

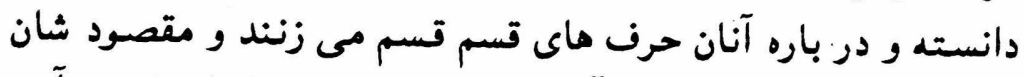

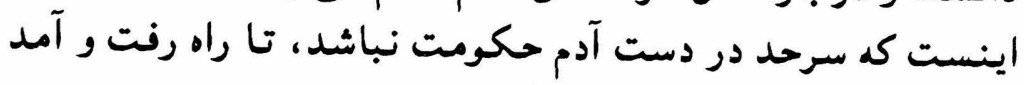
مغرضين بسته نشود . مين.

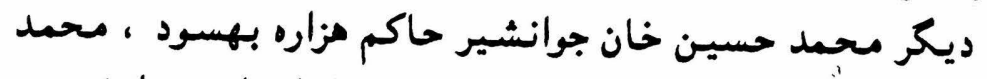

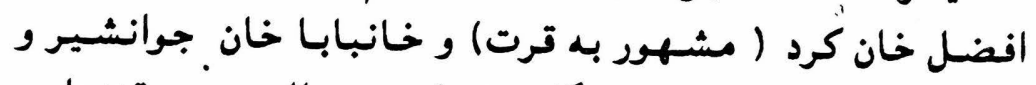

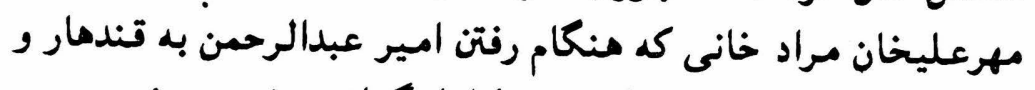

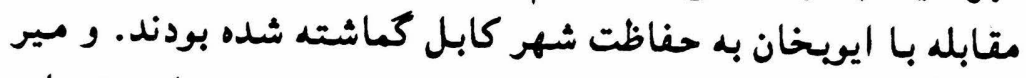

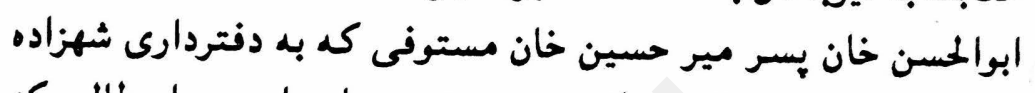

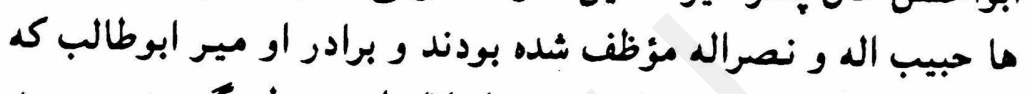

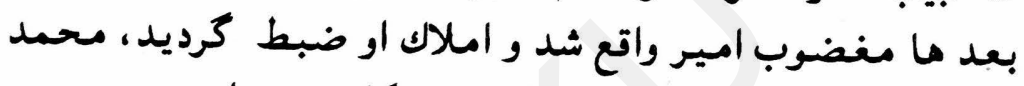

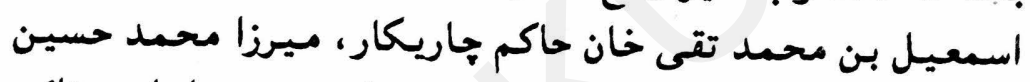

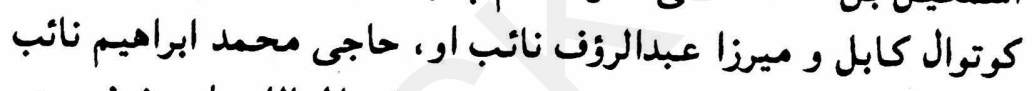

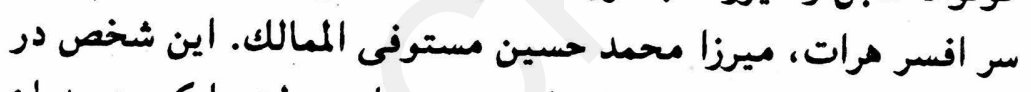

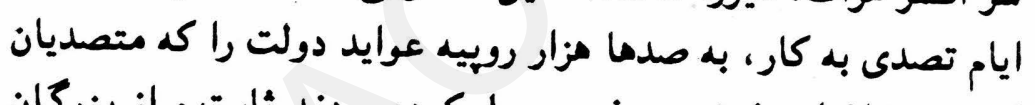

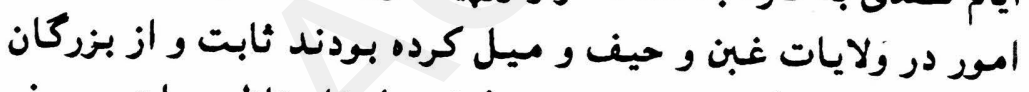

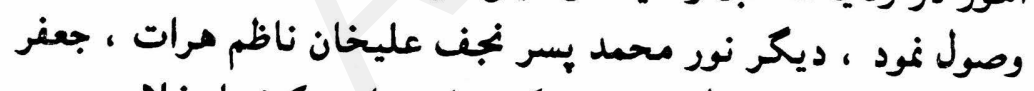

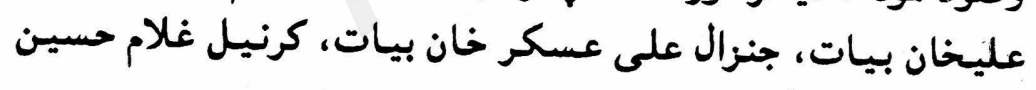
خان و تعداد ديكر. از آنجه كه بصورت جسته و كريخته در اوراق تاريخ ثبت است

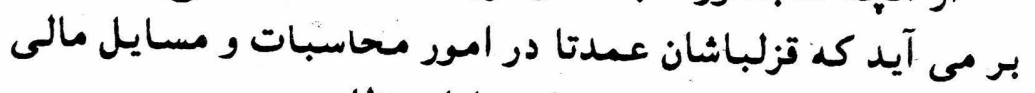

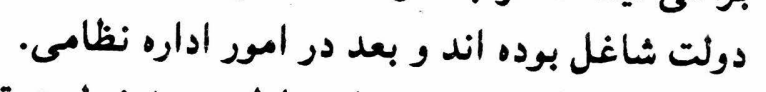

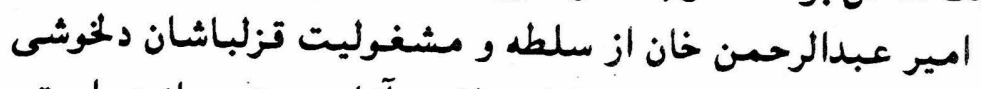

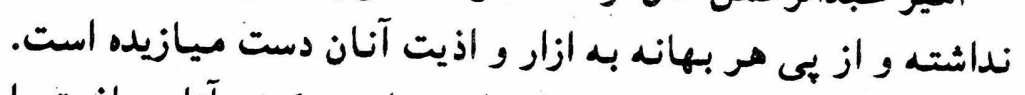

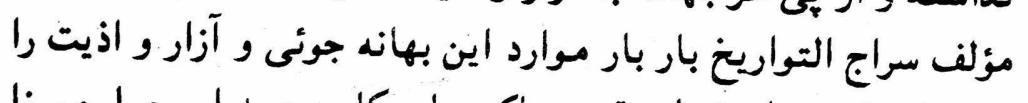

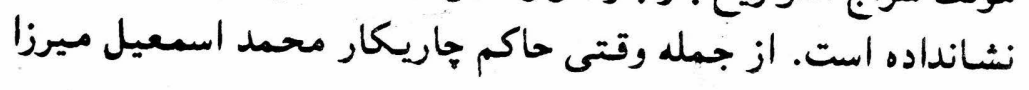


كبدالحسيسن خان بن ميرزا محسن خان را شبى در خانه اش دعوت

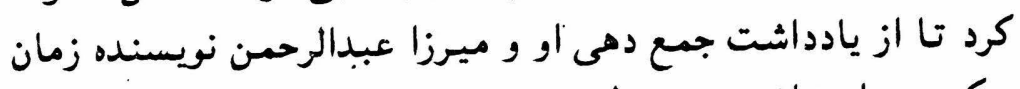

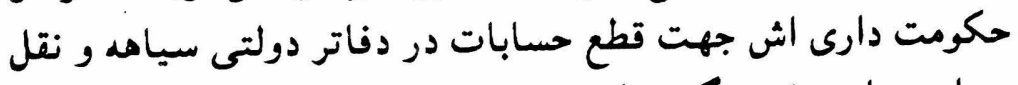

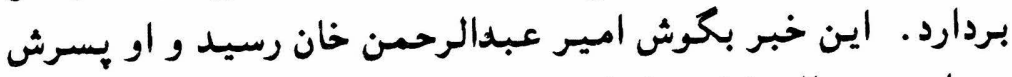

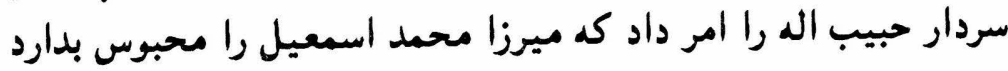

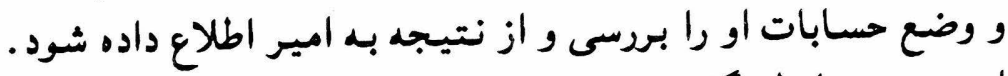

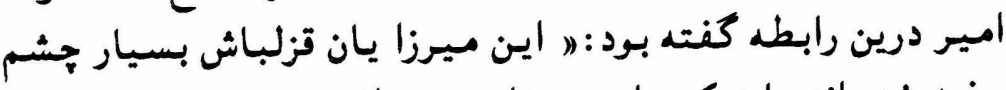

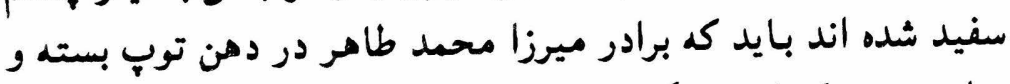

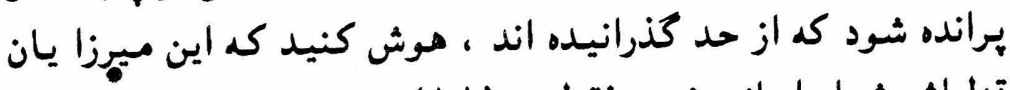

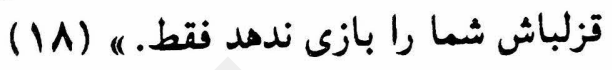

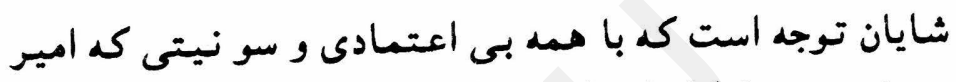

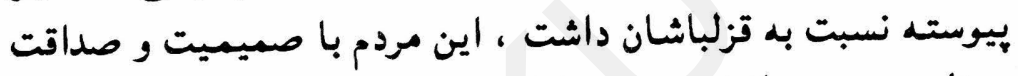

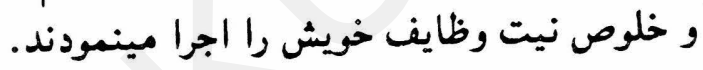

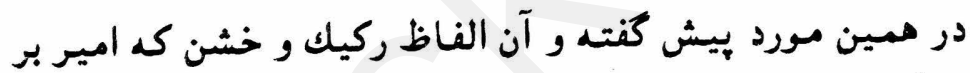

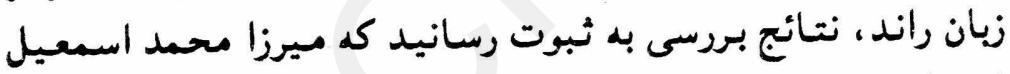

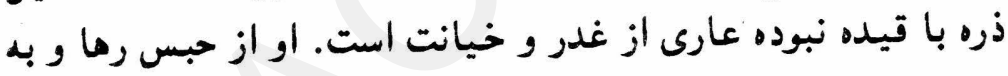

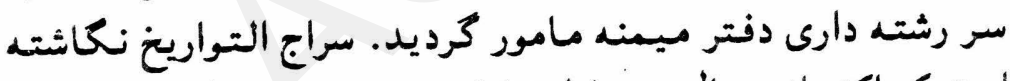

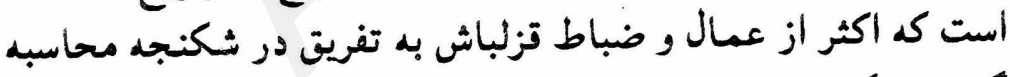

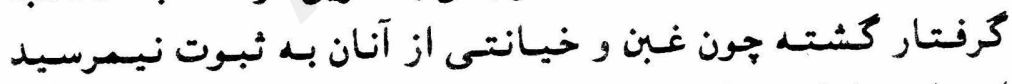

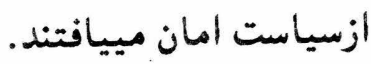

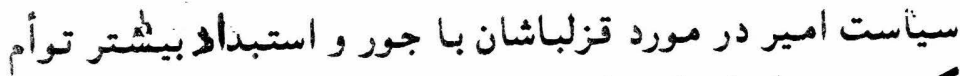

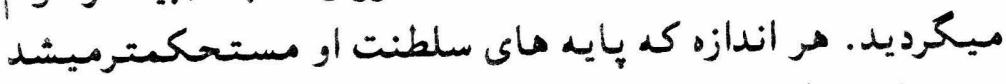

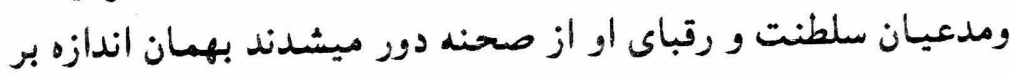

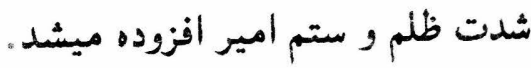

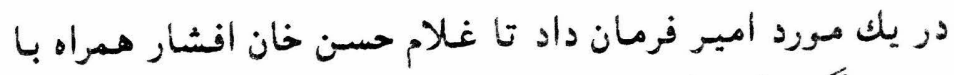

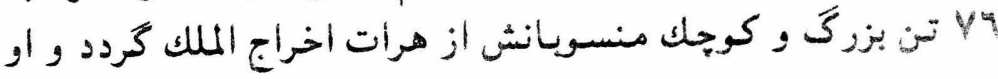


مجبور شد تا دست از همد هست و بود خود برداشته ترك يار و

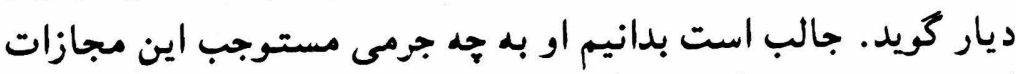

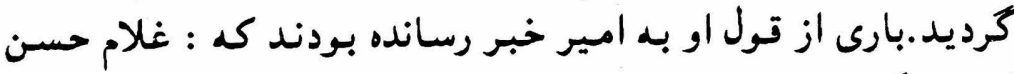

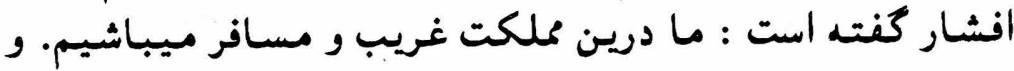

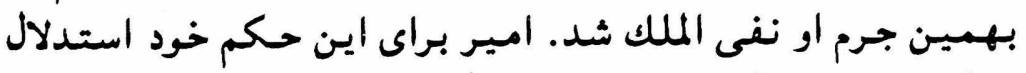

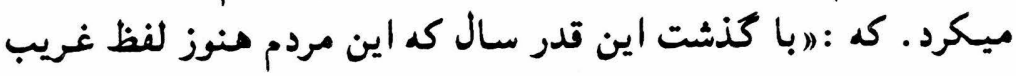

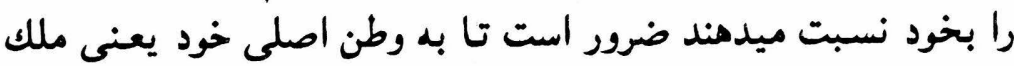
ايران بروند تا از غريت نجات يابند هـ .

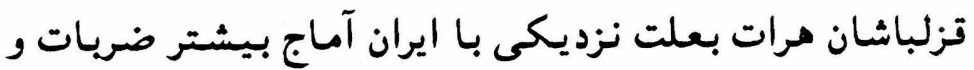

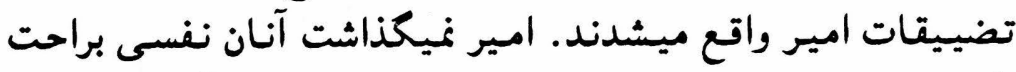

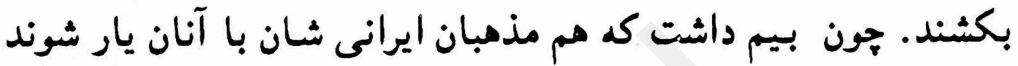

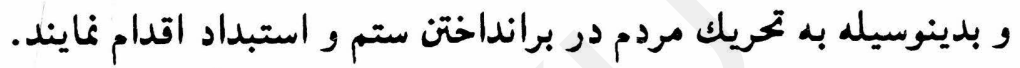

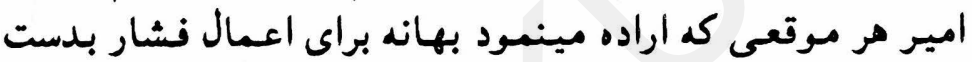

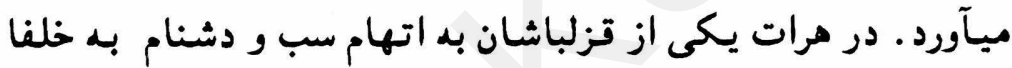

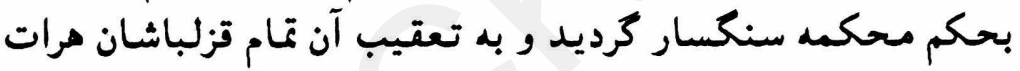

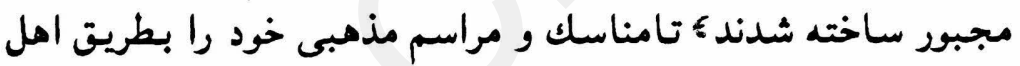

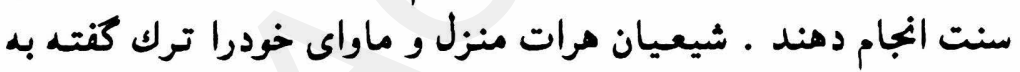
مشهد يناه بردند

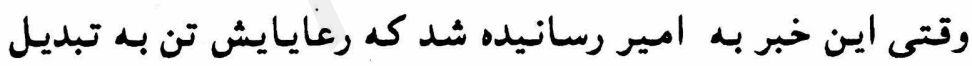

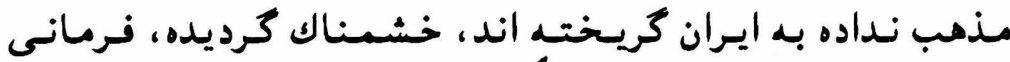

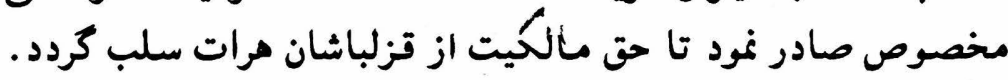

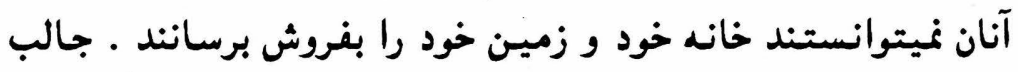

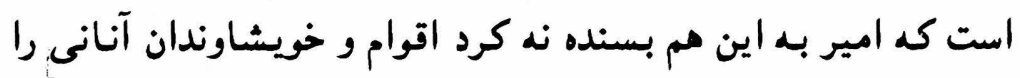

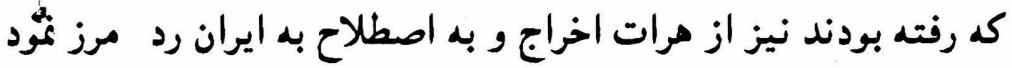

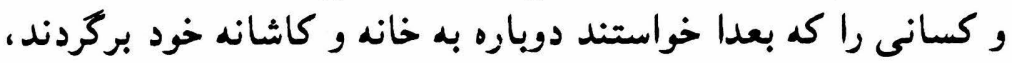

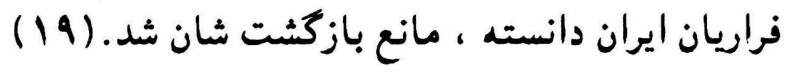


سياست تضييت و فشار دولت عليه قزلباشان آنقدر اختناق آور

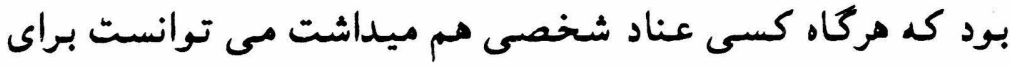

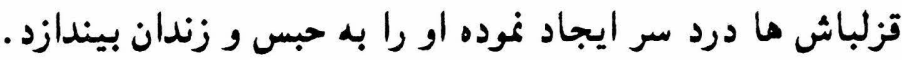

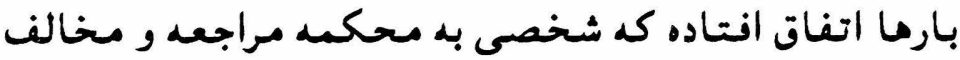

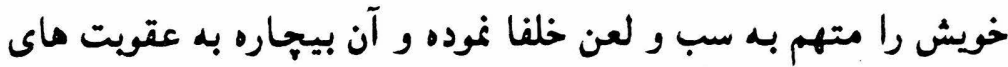

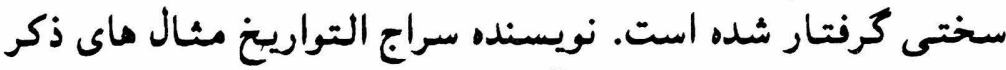

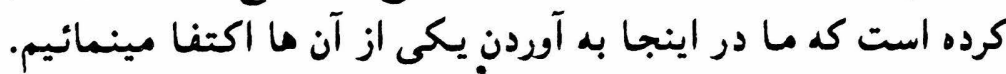

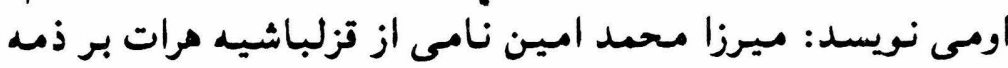

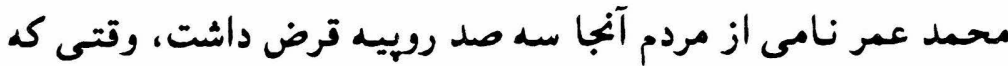

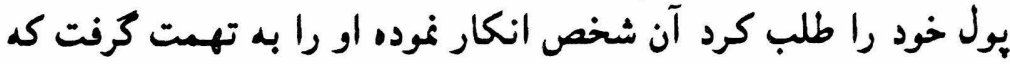

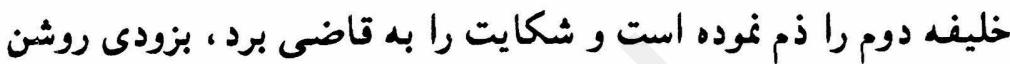

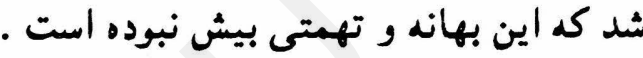

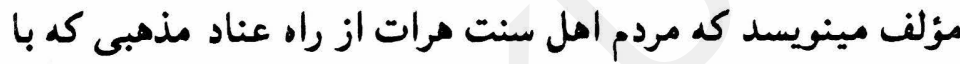

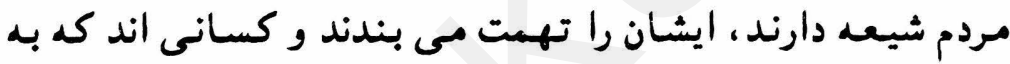

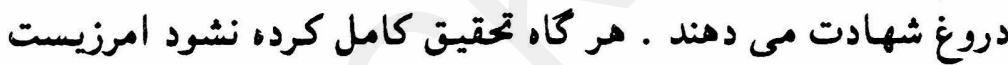

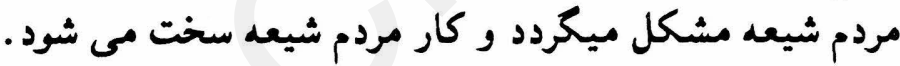

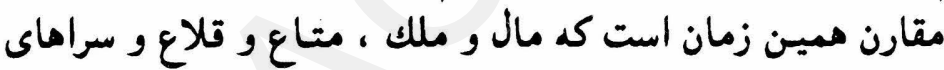

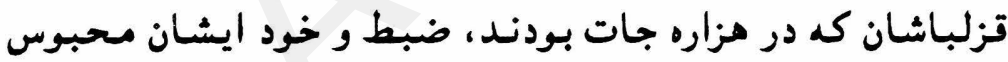

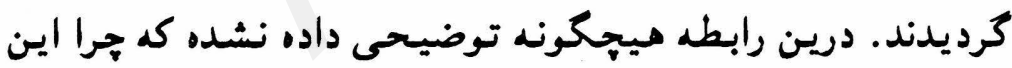

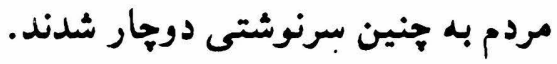

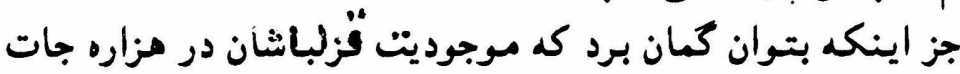

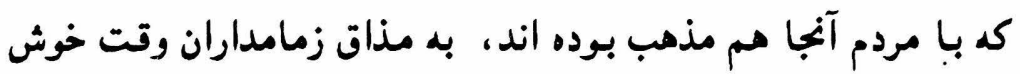

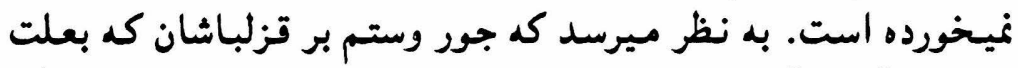

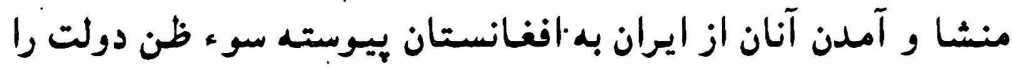

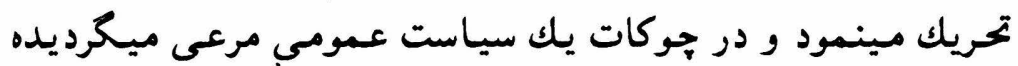

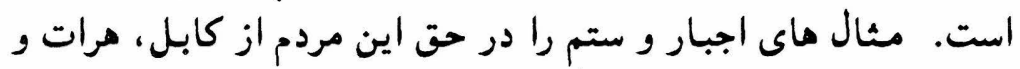


هزاره جات آورده شد. اينك از قزلباشـان قـندهار كه آنان نيز كاه

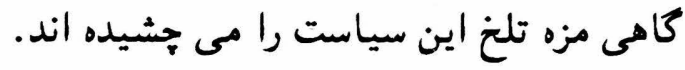

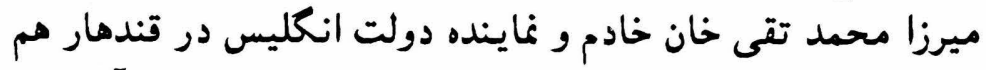

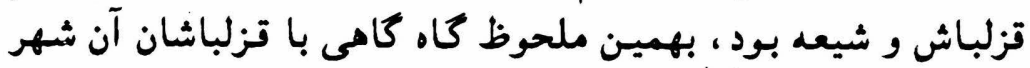

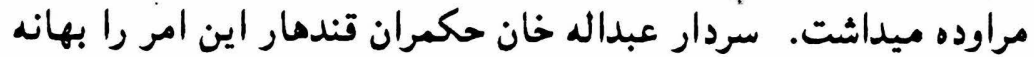

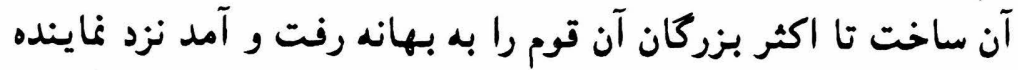

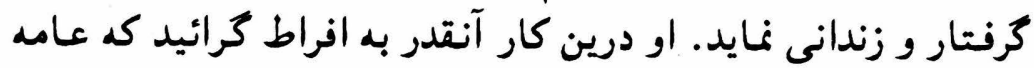

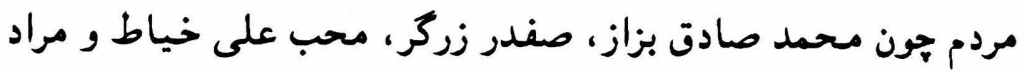
على بقال را نيز بهمين بهانه به زندان انداخت

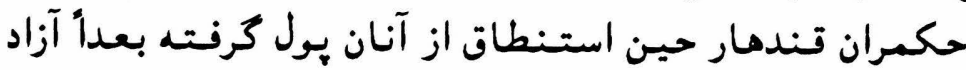

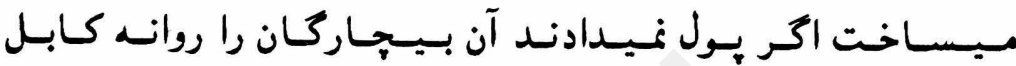

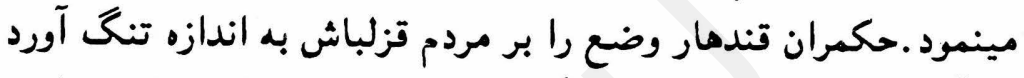

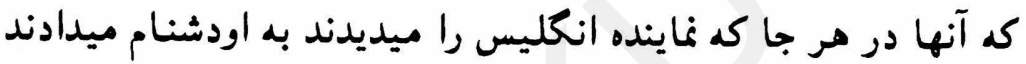

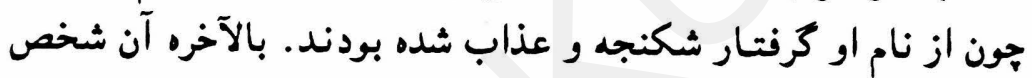

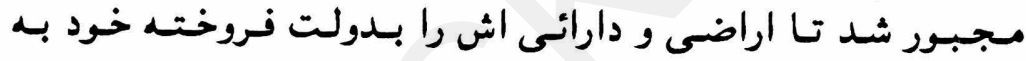

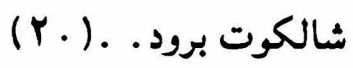

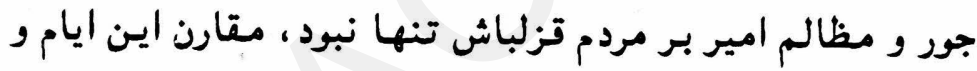

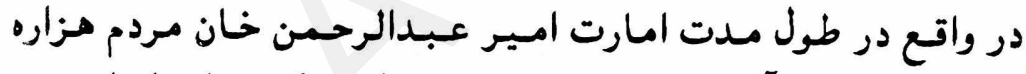

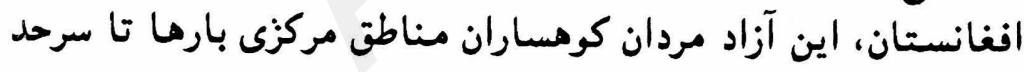

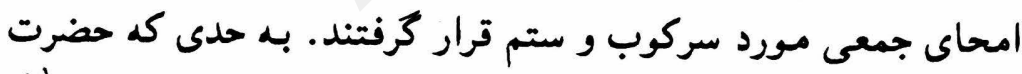

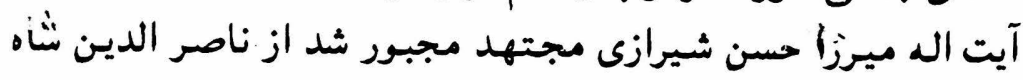

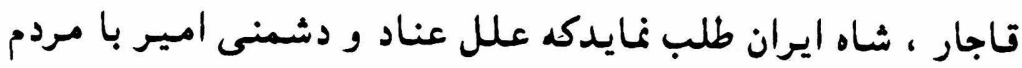

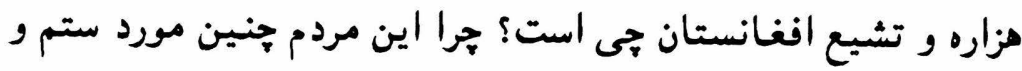
استبداد قرار ميكيرند؟ تئمان

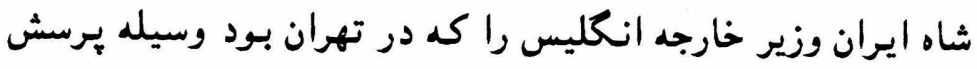

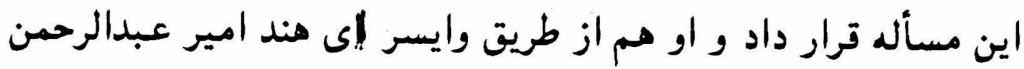


خان را مسؤول ساخت. امير در جنين مواردى كه خارجى ها در امور

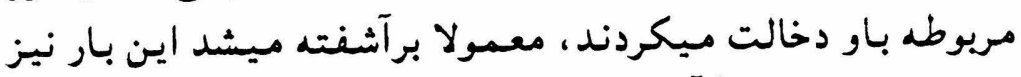

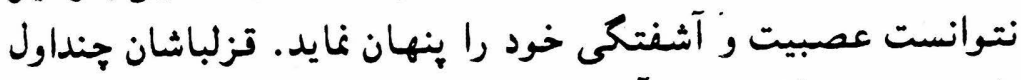

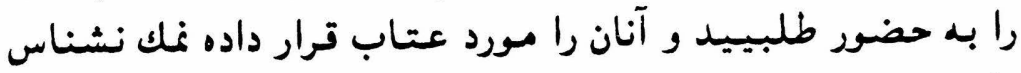
دانست.

ميرزا ابوالقاسم از سادات قزلباش به امير اطمينان داد كه جواب

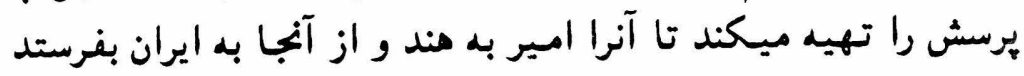

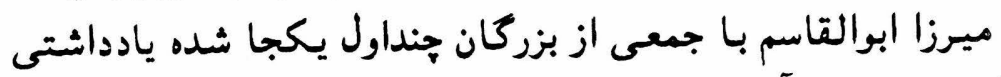

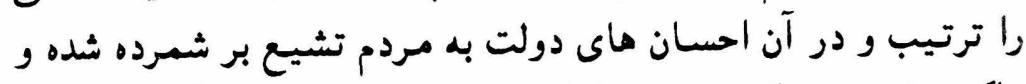

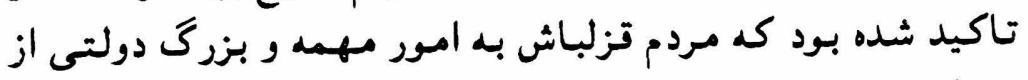

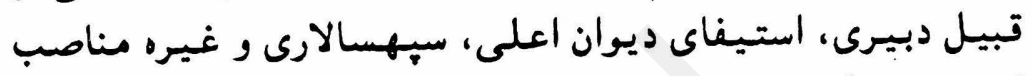

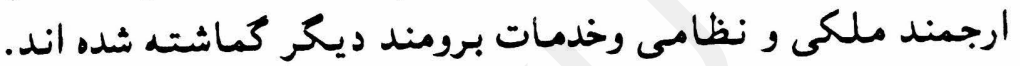

اين بادرميانى دولت ايران نه تنها مفيد واقع نشـد بلكه آتش واتش

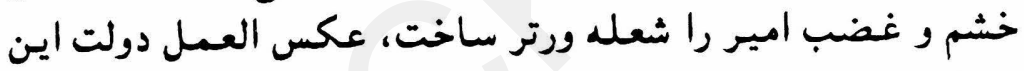

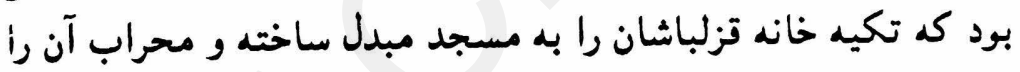

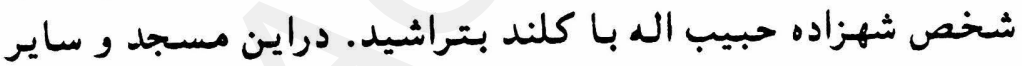

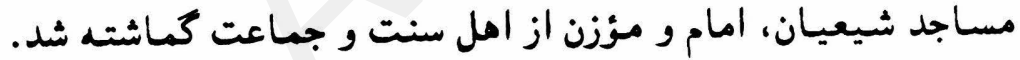

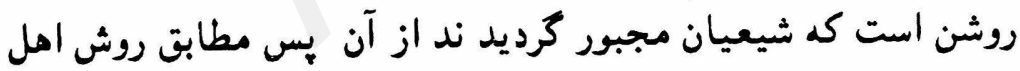

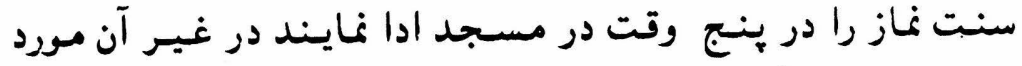

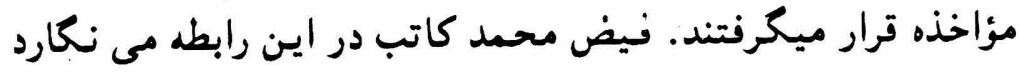

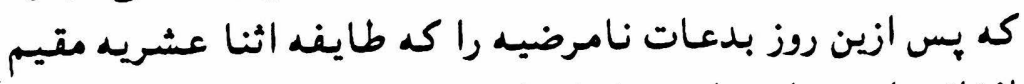

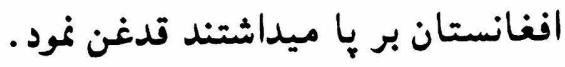

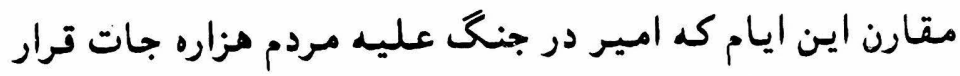

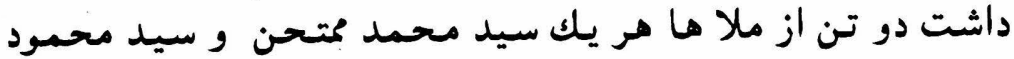

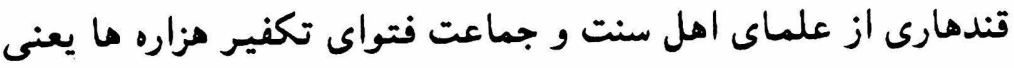




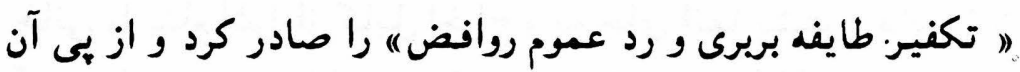

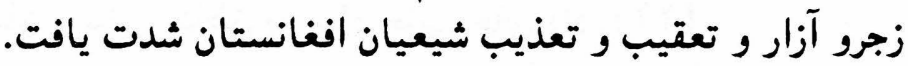

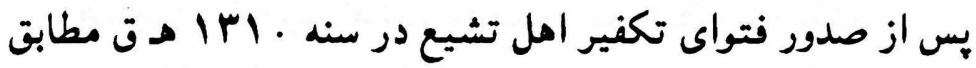

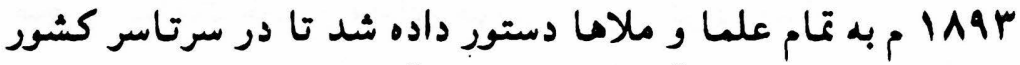

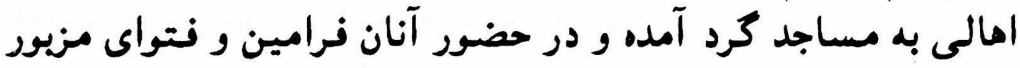

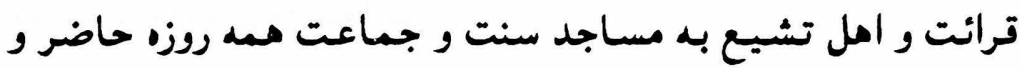

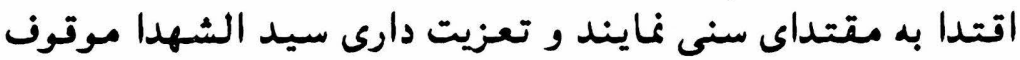
كرديد.

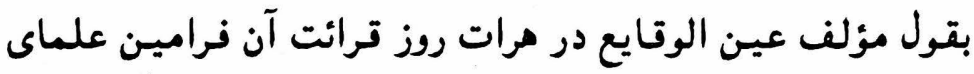

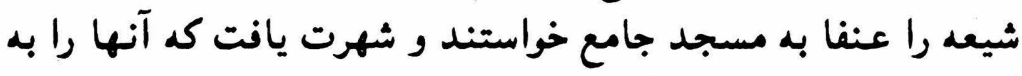

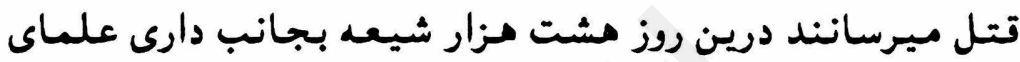

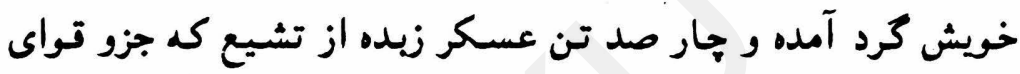

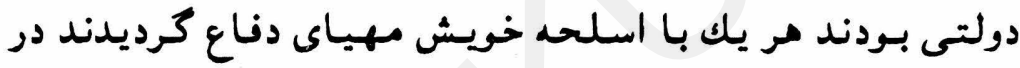

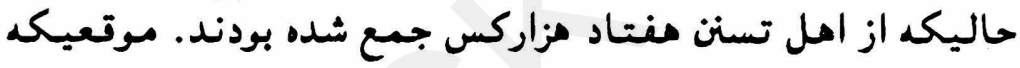

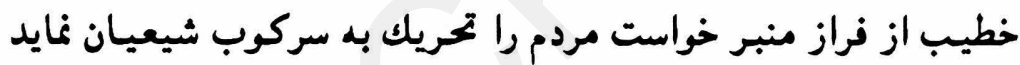

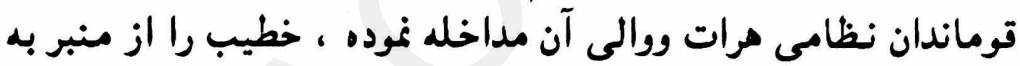

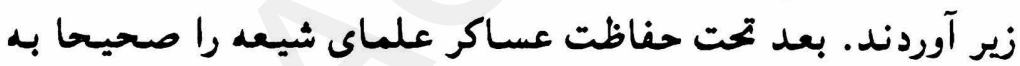

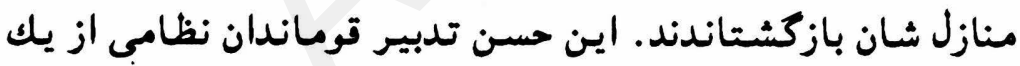

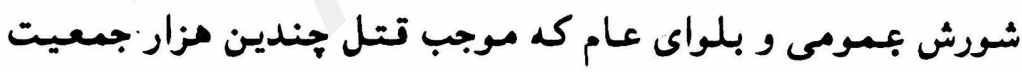

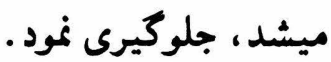

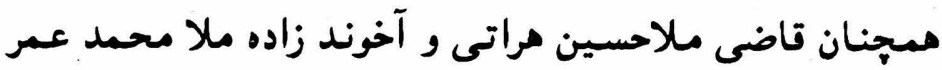

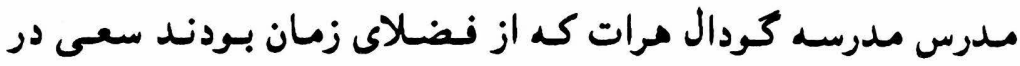

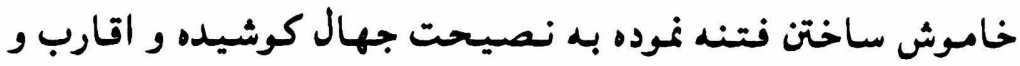

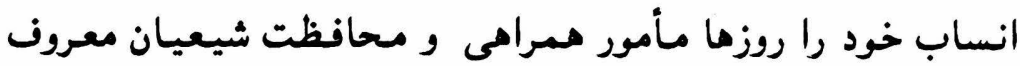
هرات مينمودند.

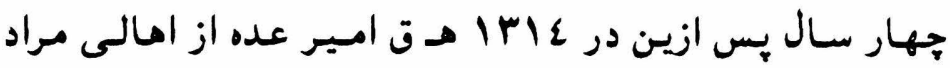




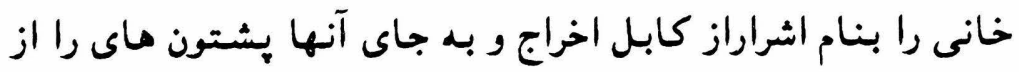

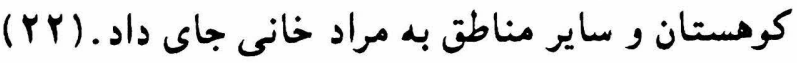

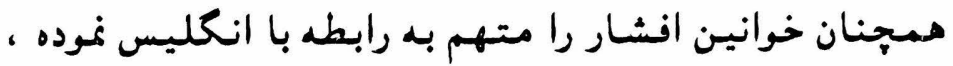

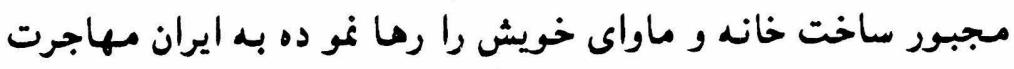

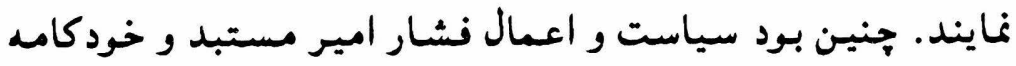

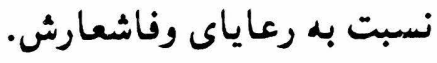

9. 


\section{مآخذ و يادواشت هاى اين فصل برائ}

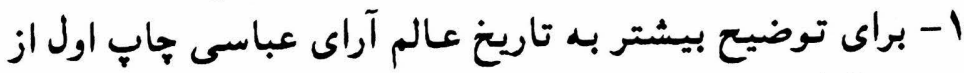

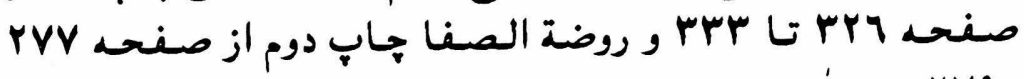

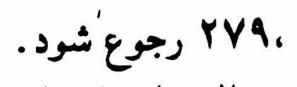

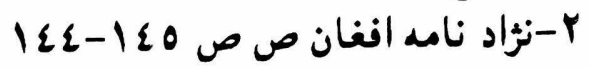

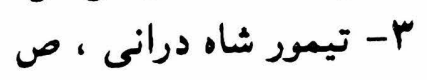

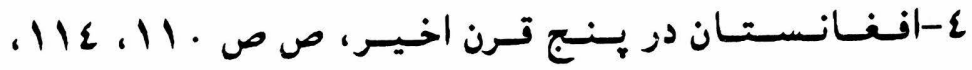
شود.

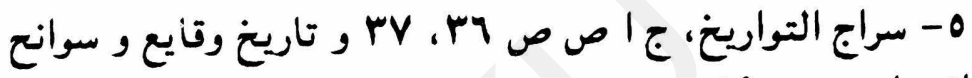

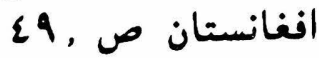

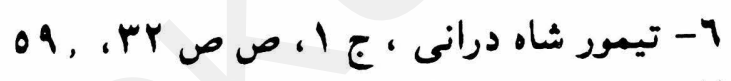

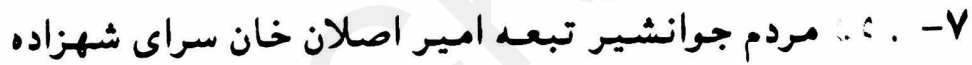

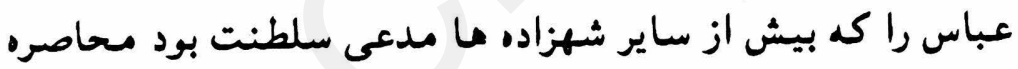

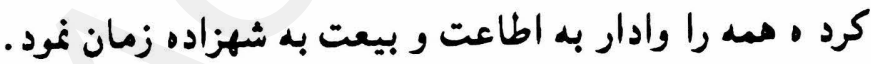

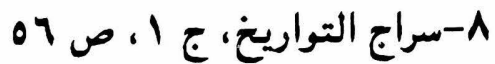

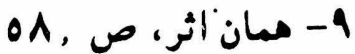

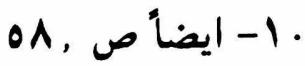

$$
\begin{aligned}
& \text { 11 }
\end{aligned}
$$

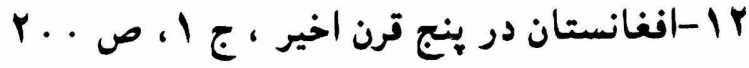

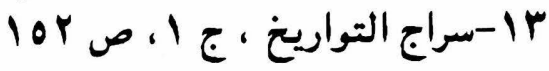

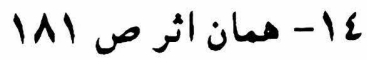

$$
\begin{aligned}
& 10
\end{aligned}
$$

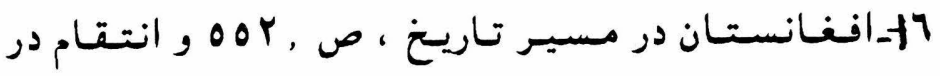




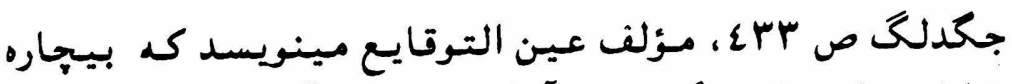

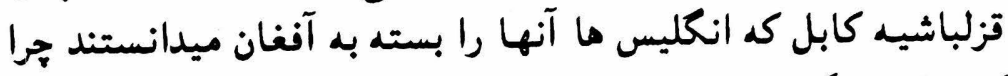

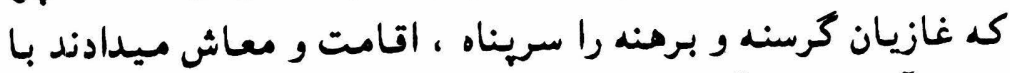

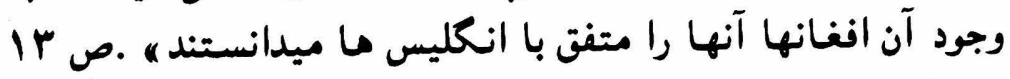

$$
\text { عين الوتايع }
$$

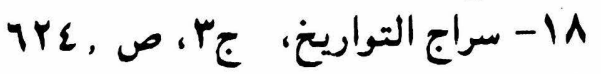

دو 19

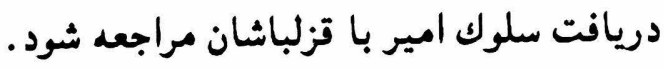

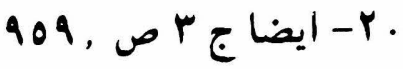

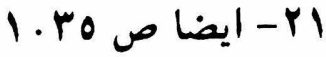

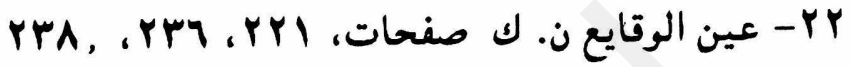

Mr 


\section{-}

\section{نفوس و محلات زيست}

\section{احصائيه نفوس در كشور:}

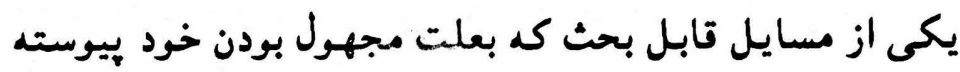

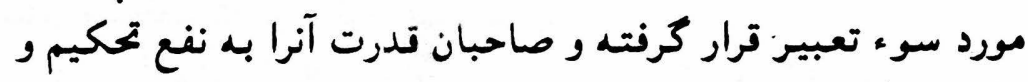

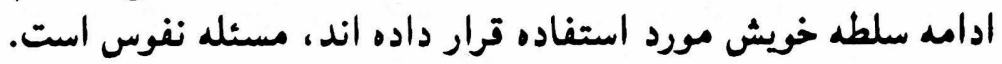

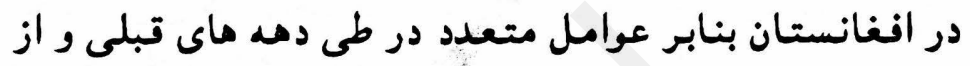

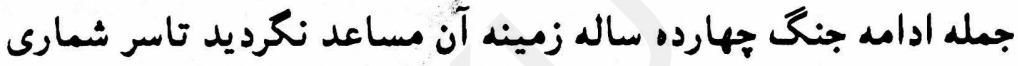

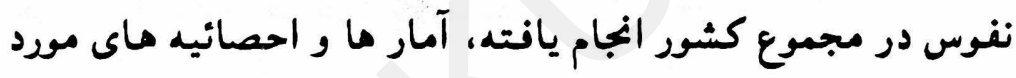

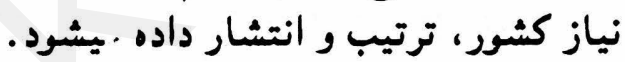

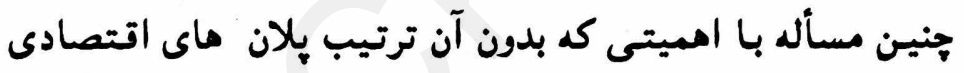

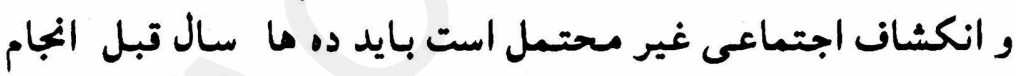

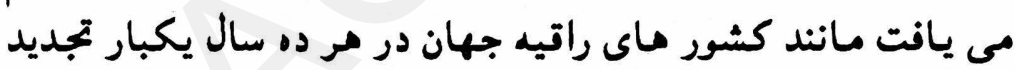

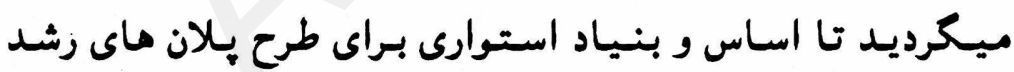

$$
\text { اقتصادى و ترقى اجتساعى ميبود. }
$$

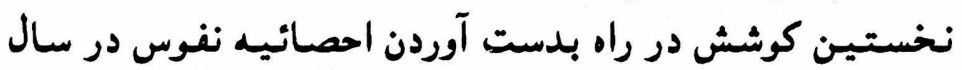

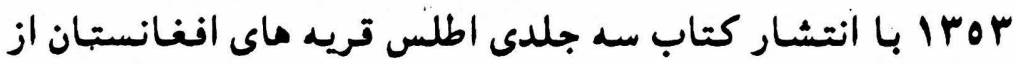

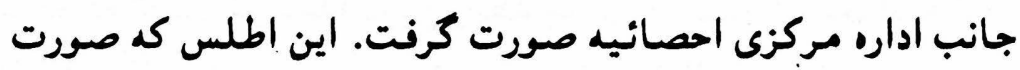

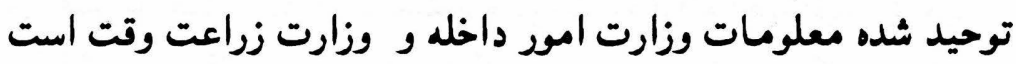

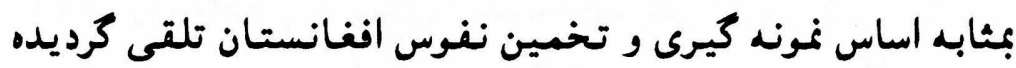

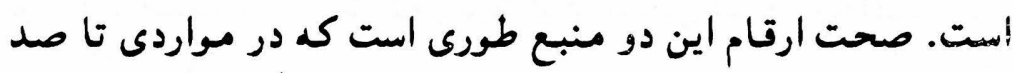

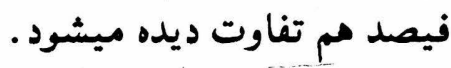




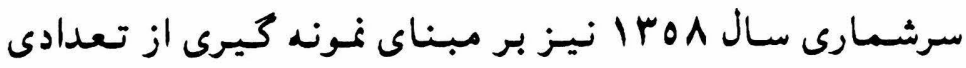

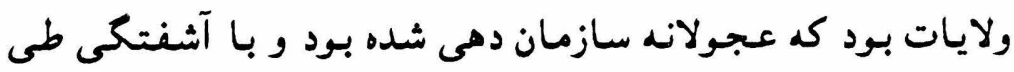

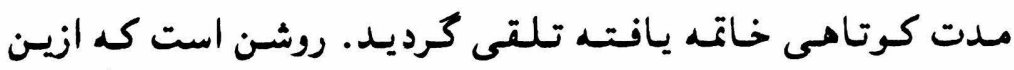

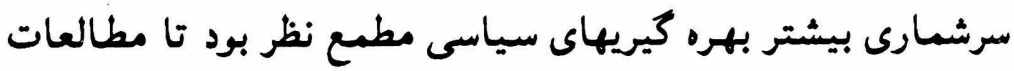

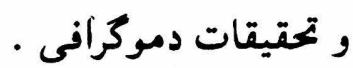

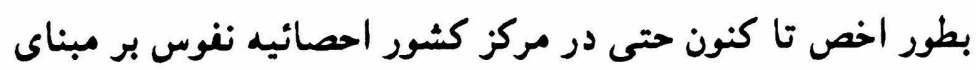

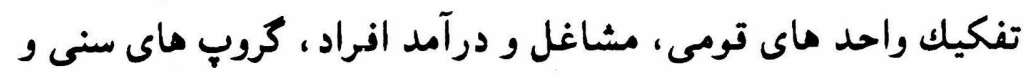

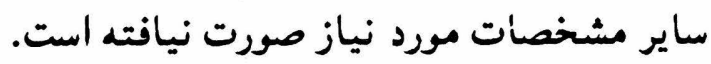

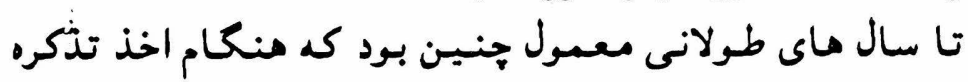

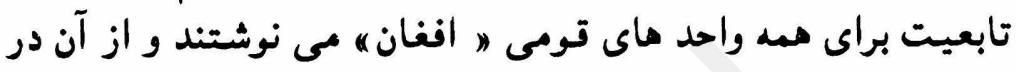

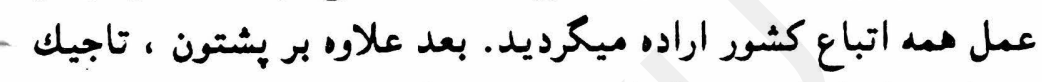

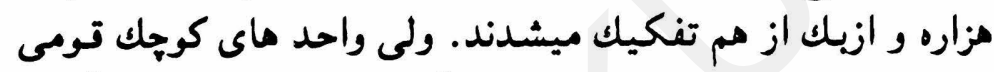

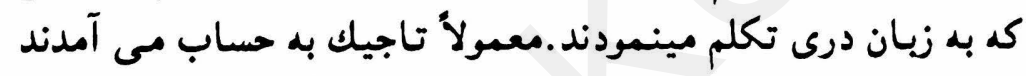

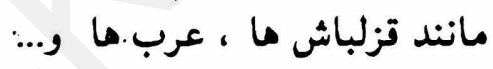

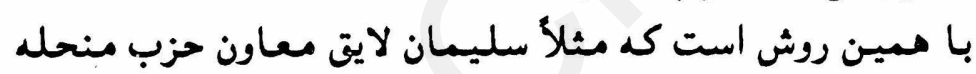

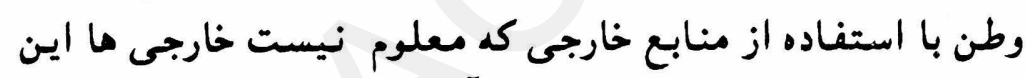

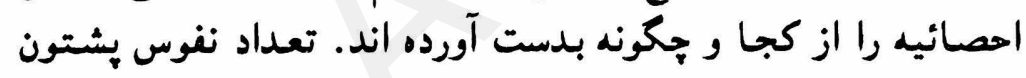

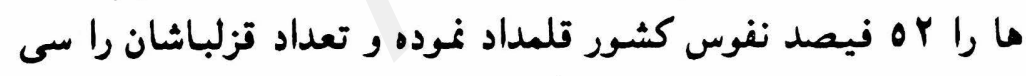

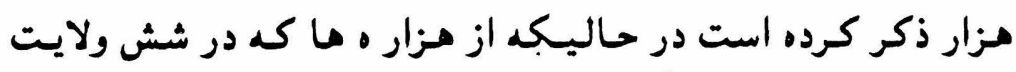

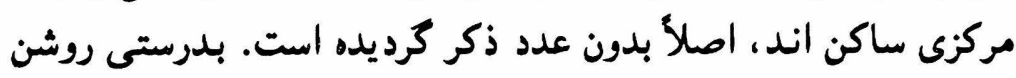

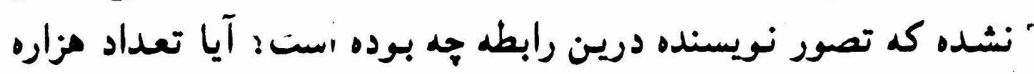

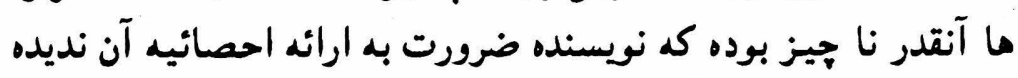

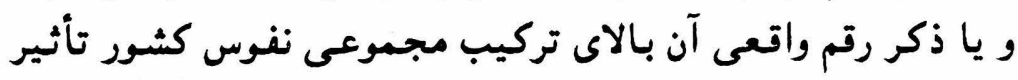

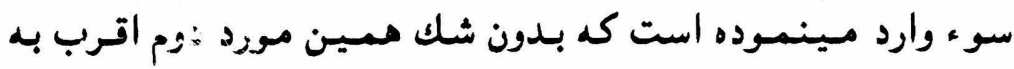
صحت است(1) 


\section{تعداد قزلباشان:}

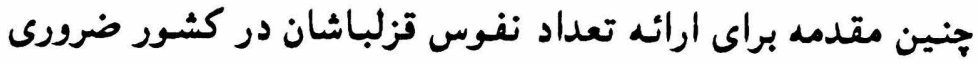

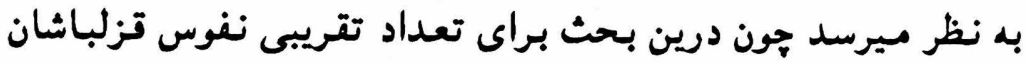

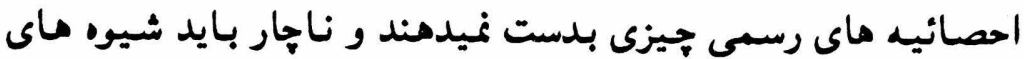
ديكرى بكار بست.

اولين بار تعداد تزلباشان در متاله با عنوان " برخورد با مسألد

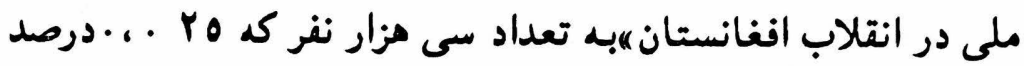

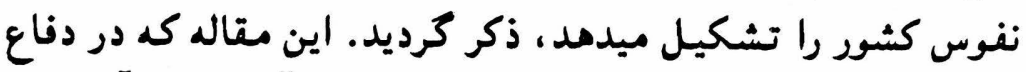

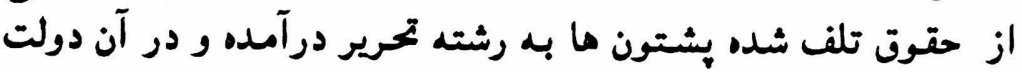

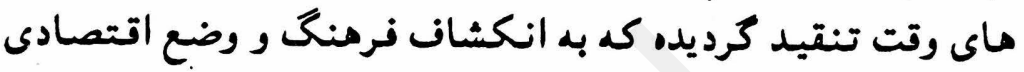
يشتون ماتوجه نكرده اند.

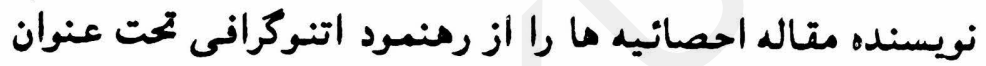

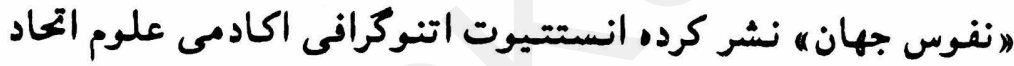

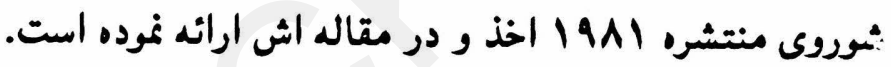

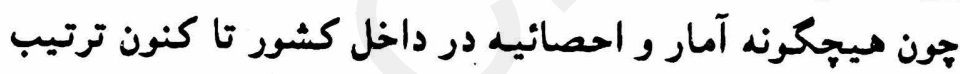

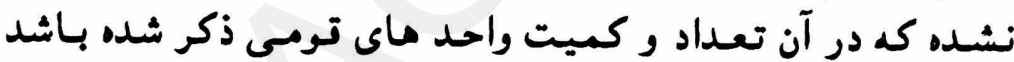

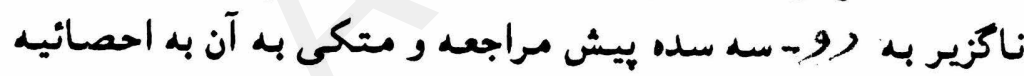

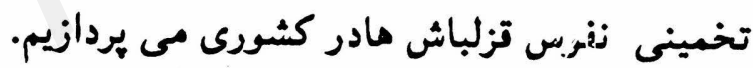

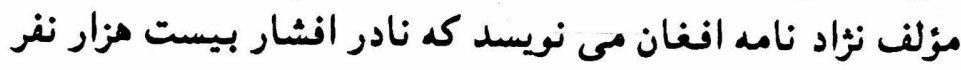

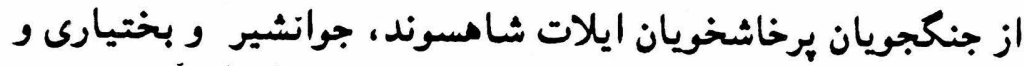

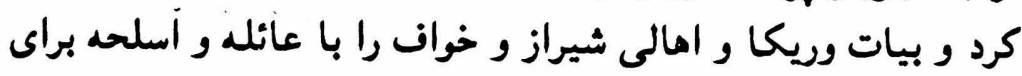

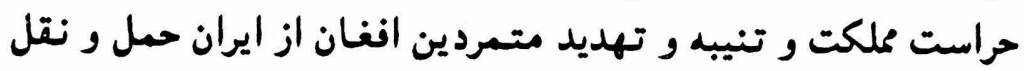

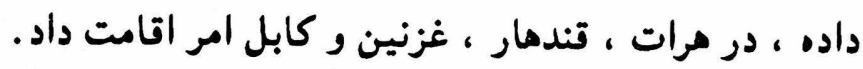

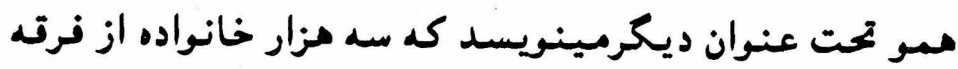

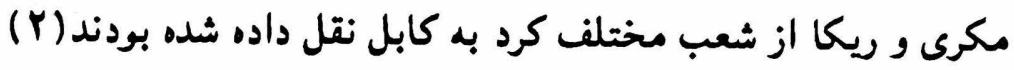

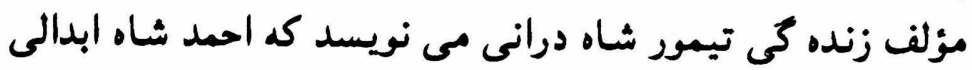


r إن هزار خانوار از امالى نيشاهيور و حوالى آنرا با خود به افغانستان (r). انتقال داد داد (r)

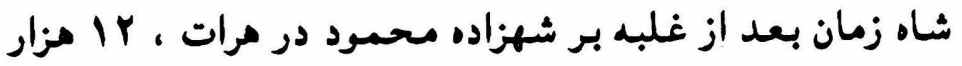

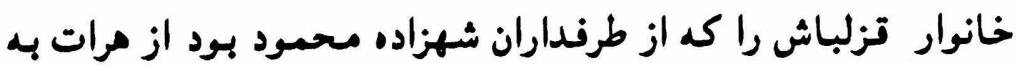
كابل كوجانيد.

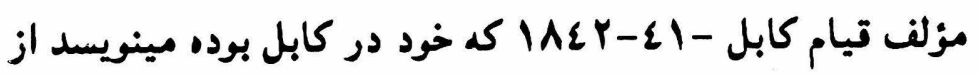

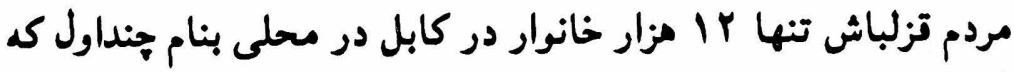

اكنون نيز بهمين نام مشهور است ، ساكن ميباشند.

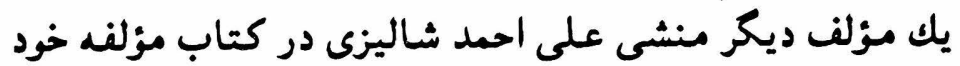

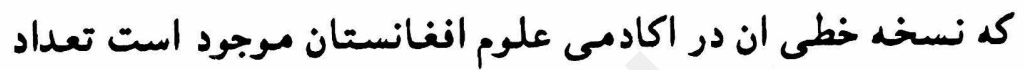

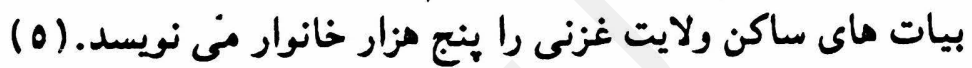

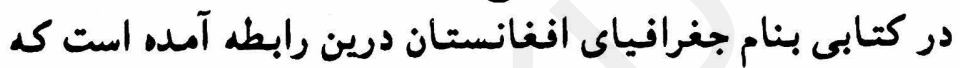

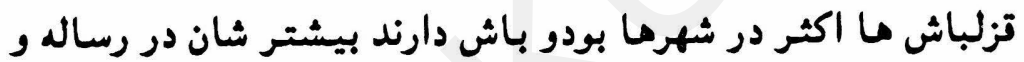

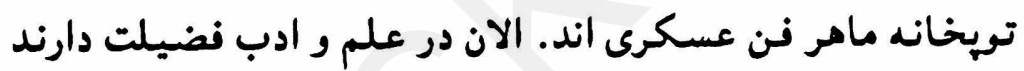

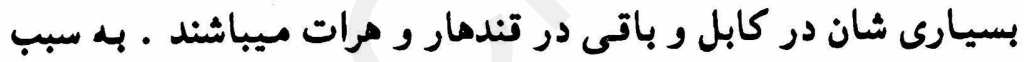

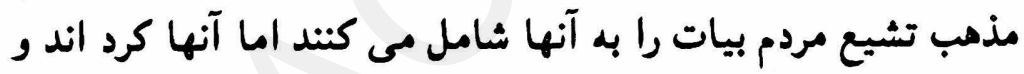

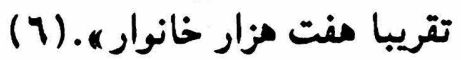

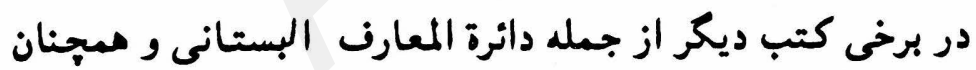
اعيان الشيعه تعداد تزلباشان دوصد مزار نفر ذكر كرديده است.

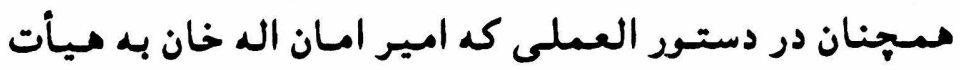

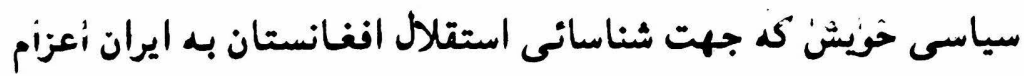

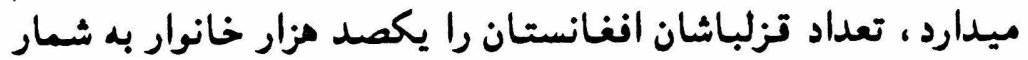

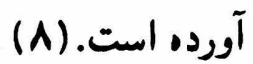

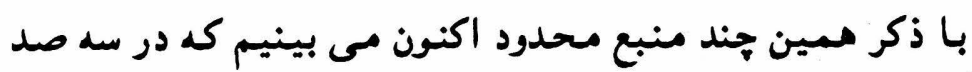

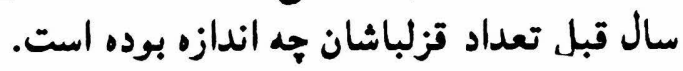


فيض محمد كاتب جمعاً س r مزار خانوار ذكر كرده، تعداد بيات

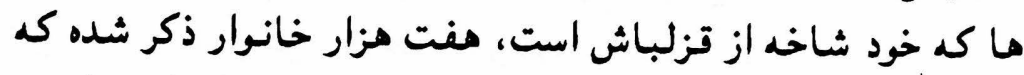

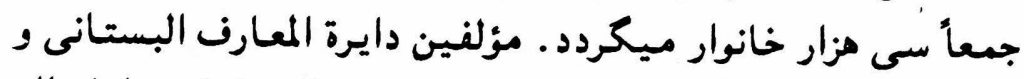

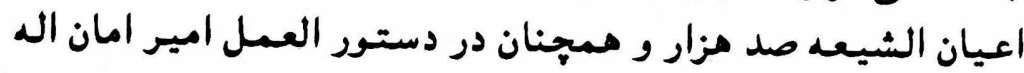

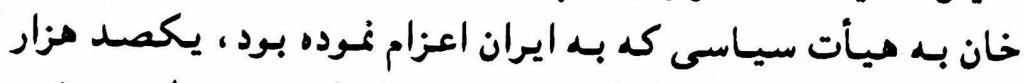

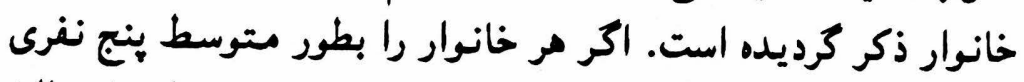

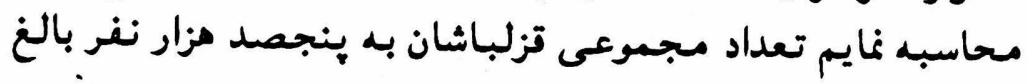

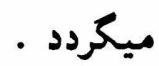

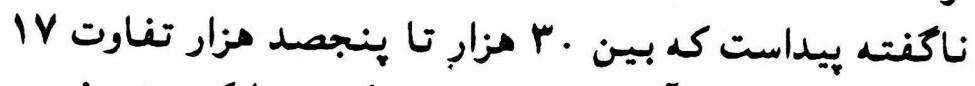

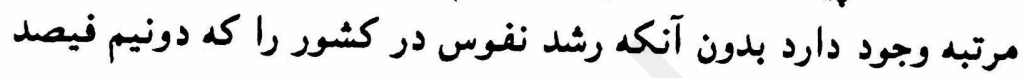
محاسبه شده در نظر بكيريم.

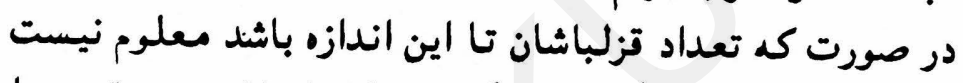

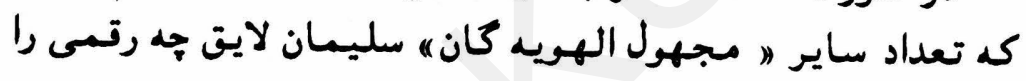
تشكيل خواهد داد. حكت تقليل و تزئيد مصنوعى نفوس در در آنست تا اكثريت ما و و

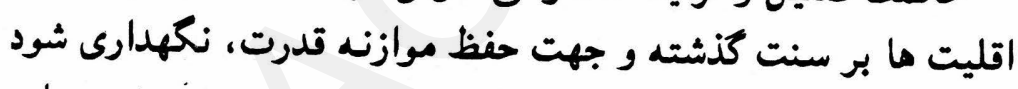

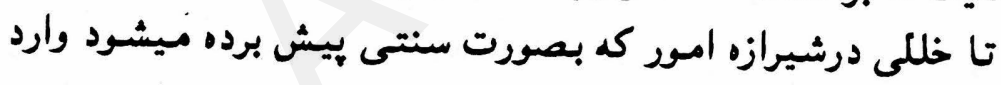
نكردد.

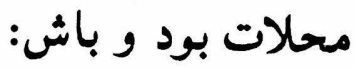

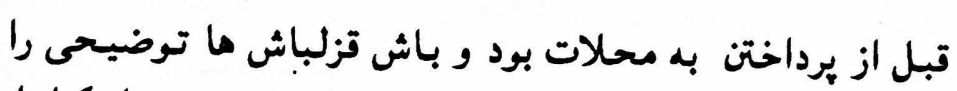

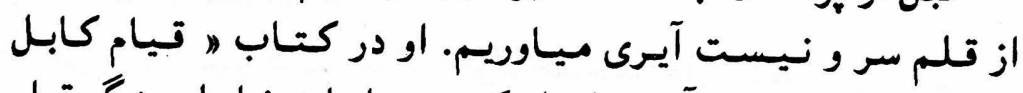

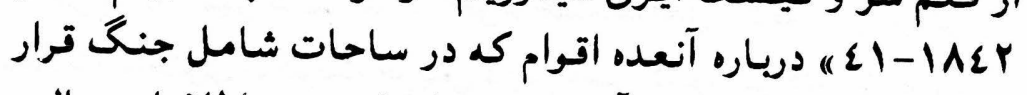

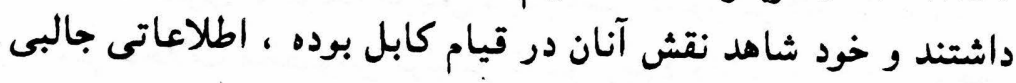
ارائه نموده است. 
او قزلباش ها را از جاتزين شده كان مهم خارجى ميداند كه تعداد ،

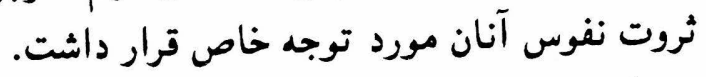

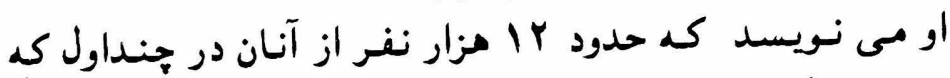

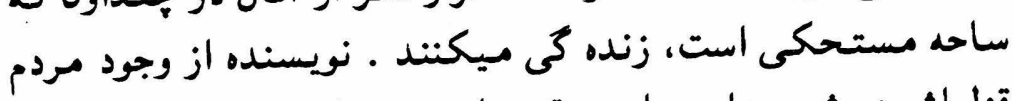

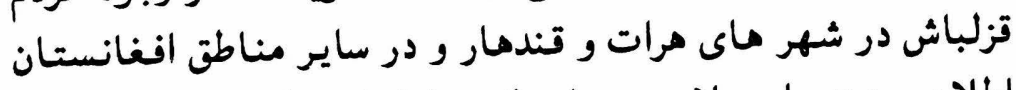

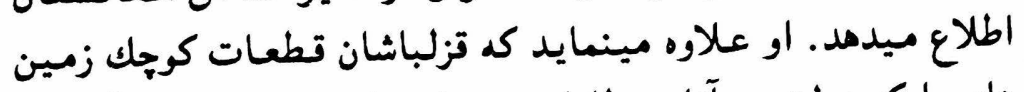

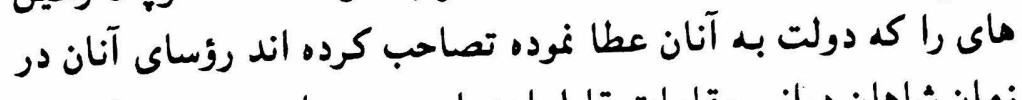

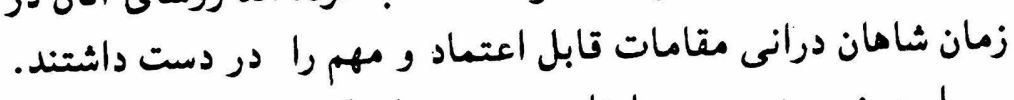

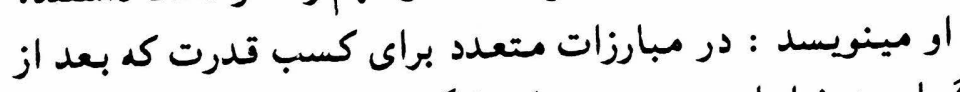

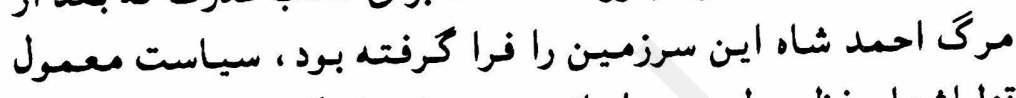

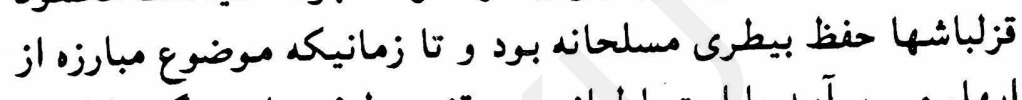

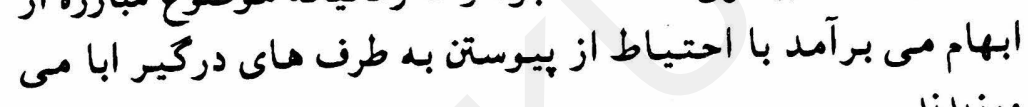
ورزيدند.

مؤلف جغرافياى انغانستان نيز درين رابطه شرحى دارد. او

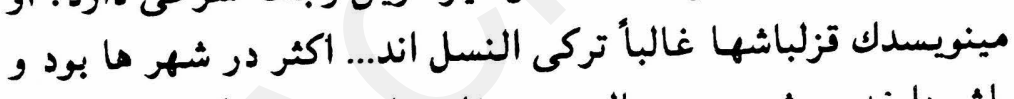

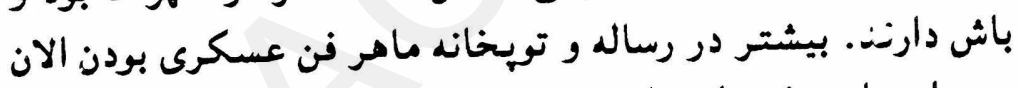

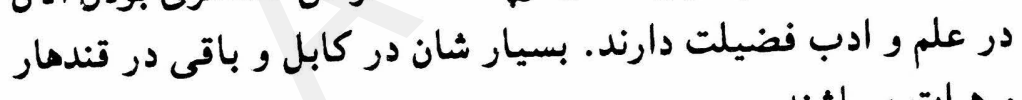
و مرات ميباشند.

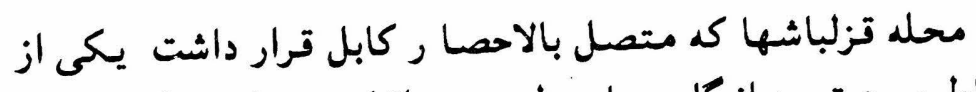

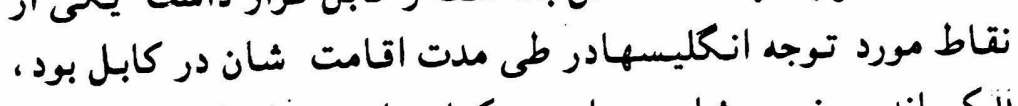

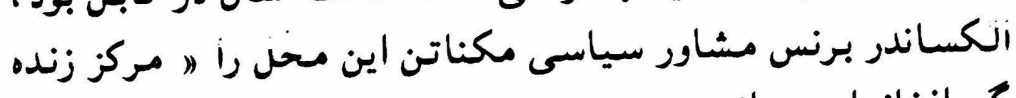
كى افغانها ، ميدانست.

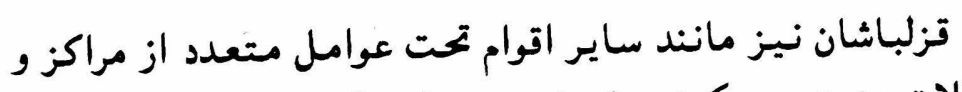

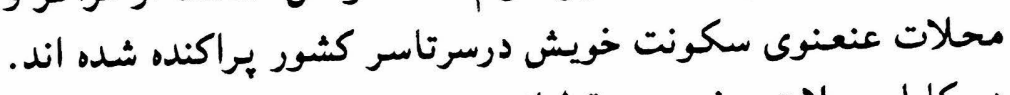

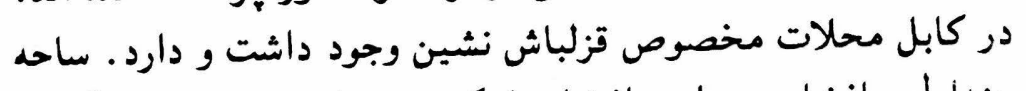

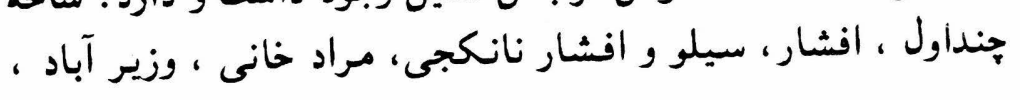


قلعه وزير و كلوله بشته و شهر آراء از محلات عمده قزلباش نشين

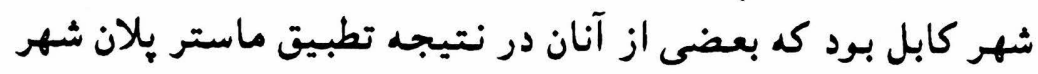

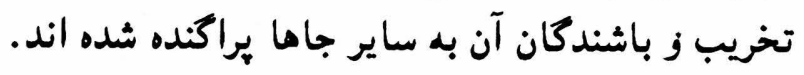

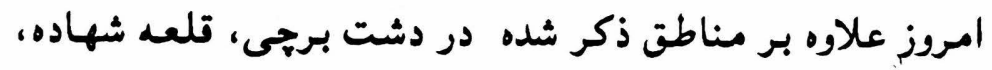

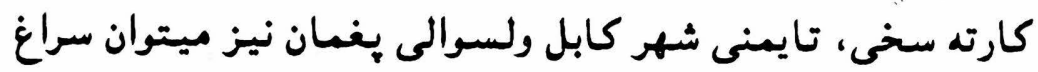
تزلباشان را كرفت.

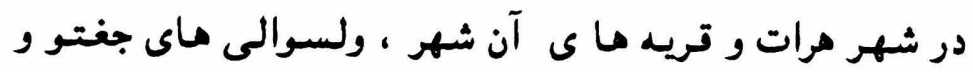

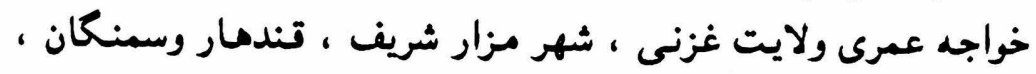

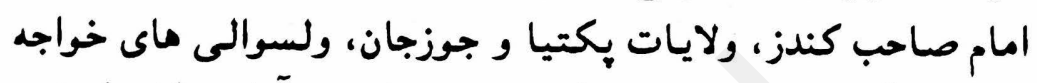

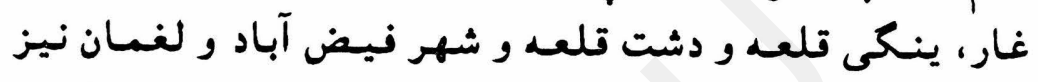

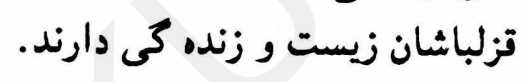

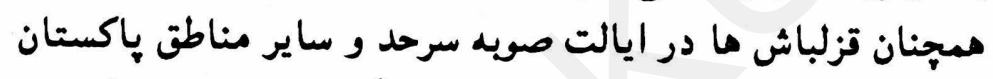

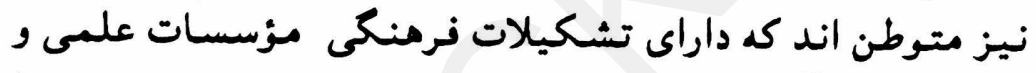

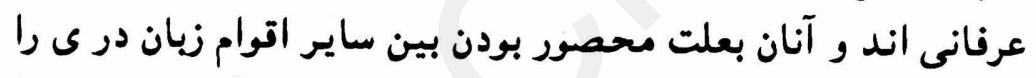

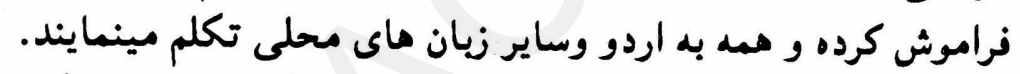

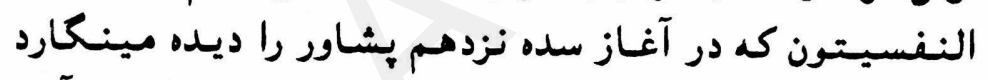

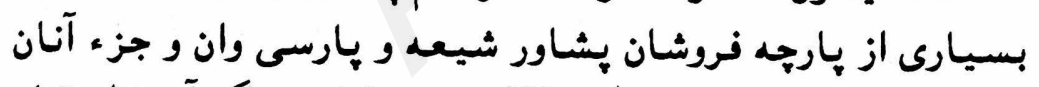

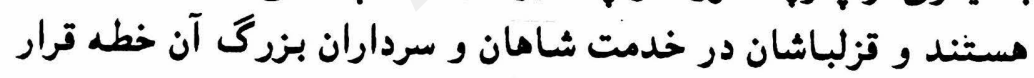
دار ند. 
ا-برخورد با مسأله ملى درانقلاب انغانستان، روزنامه حقيقت ماند

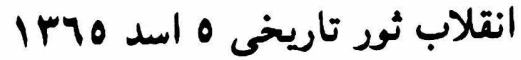

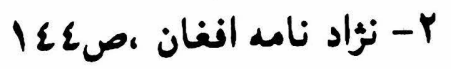

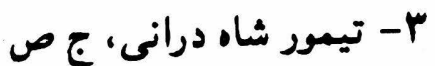

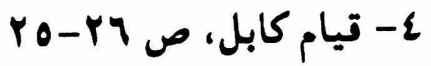

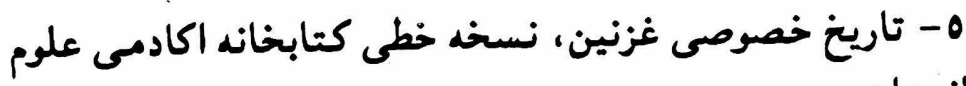

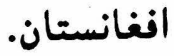

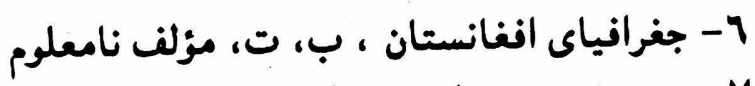

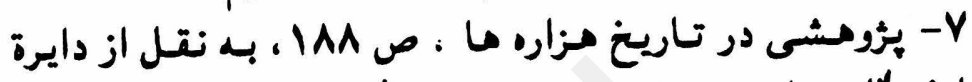

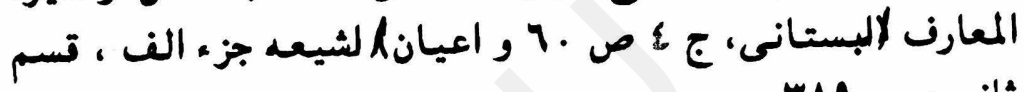

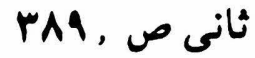

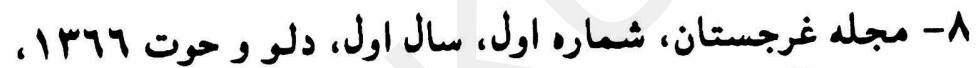

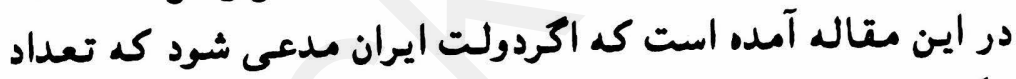

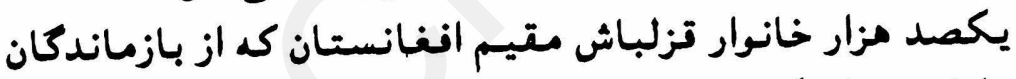

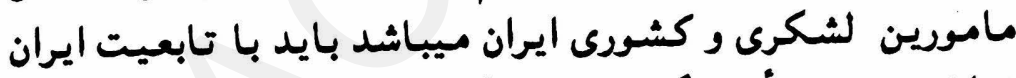

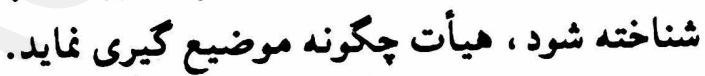

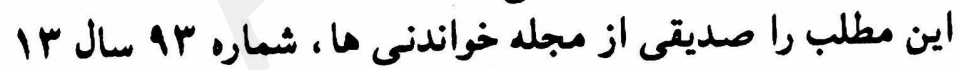

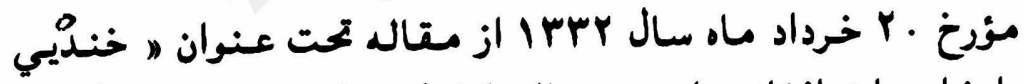

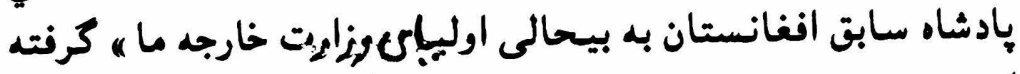




\section{0}

مذهب

شيعيان راسخ العقيده:

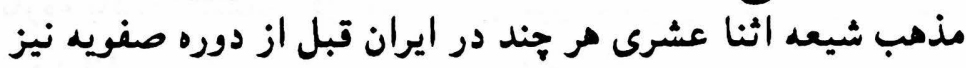

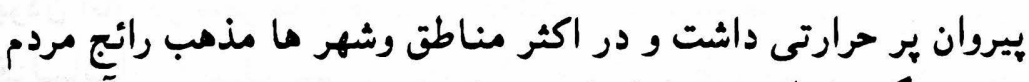

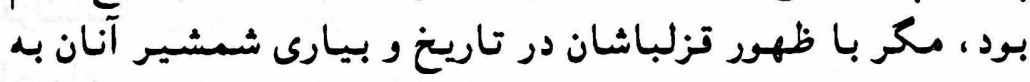

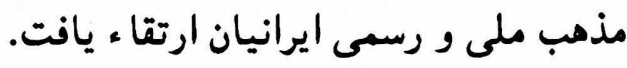

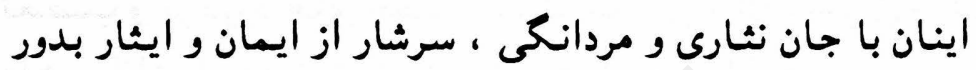

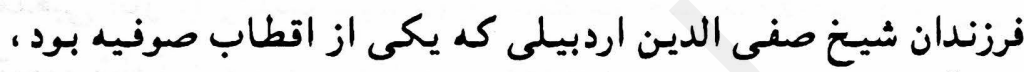

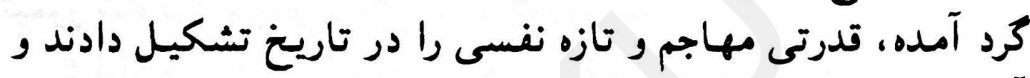

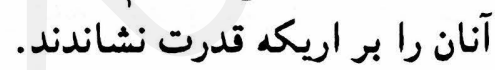

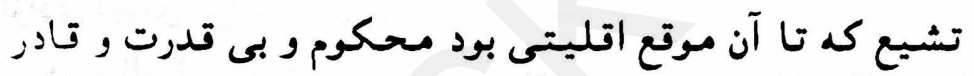

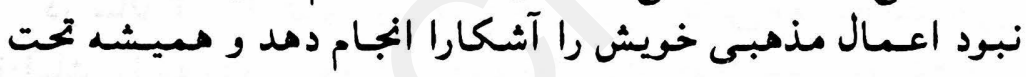

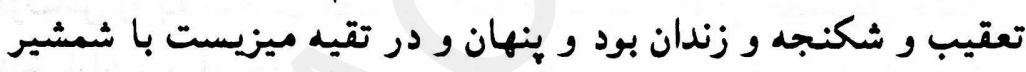

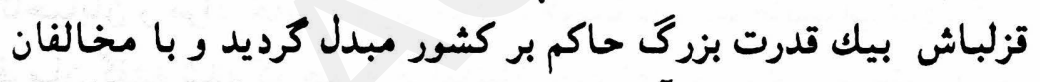

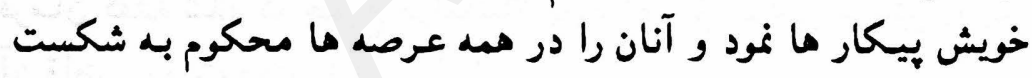

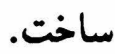

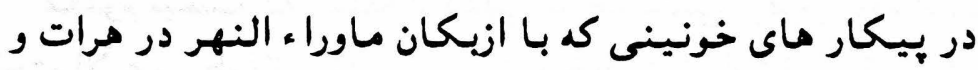

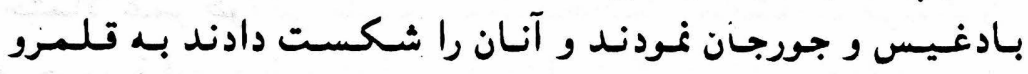

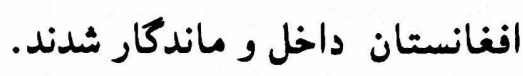

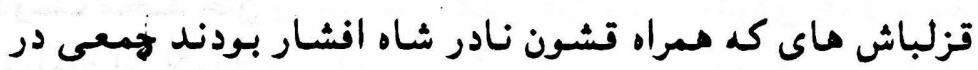

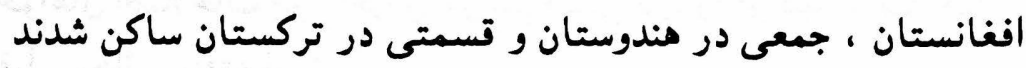

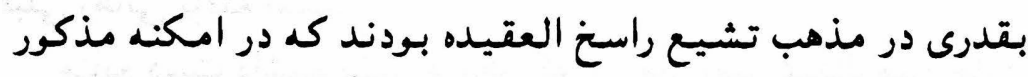

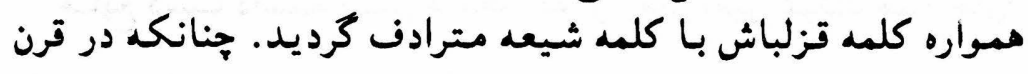




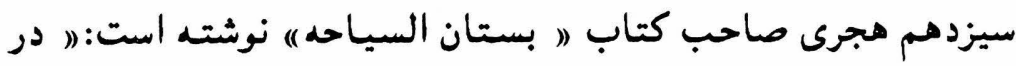

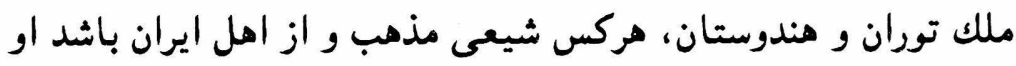

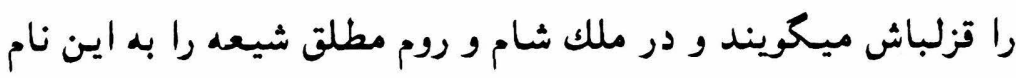

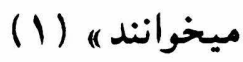

تشيع اثنا عشرى با آمدن تزلباشان به افغانستان تحرك و نيروى

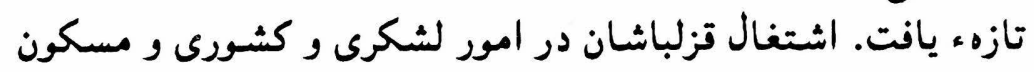

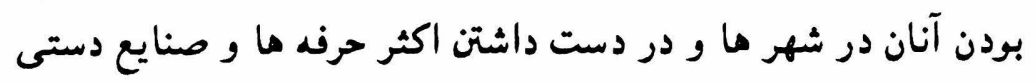

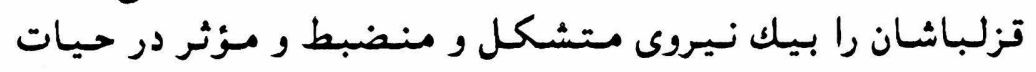

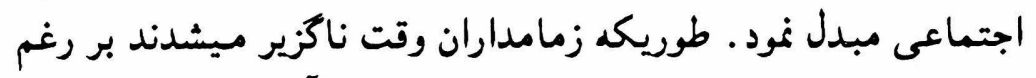

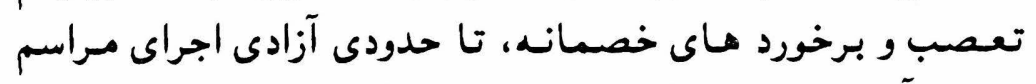

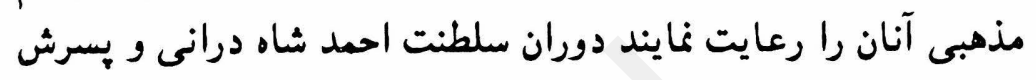

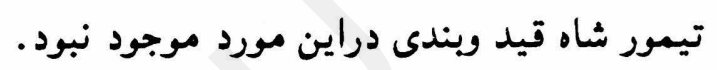

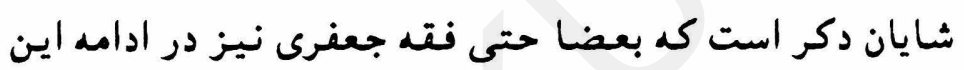

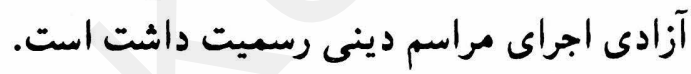

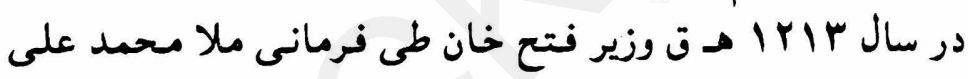

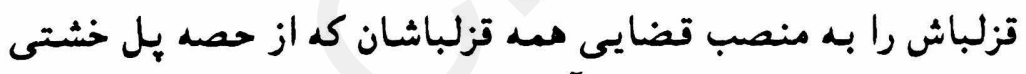

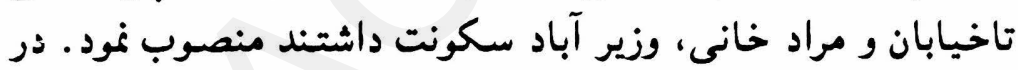

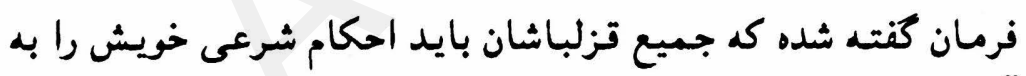

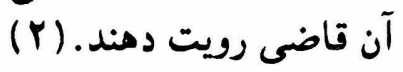

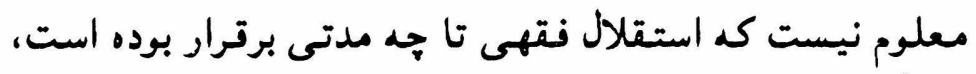

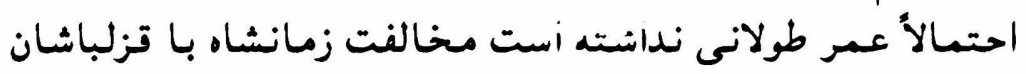

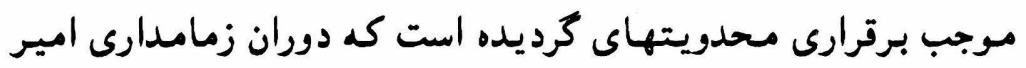

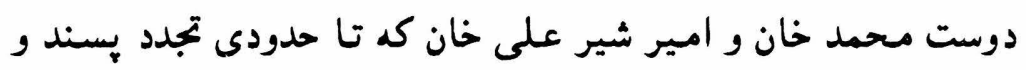

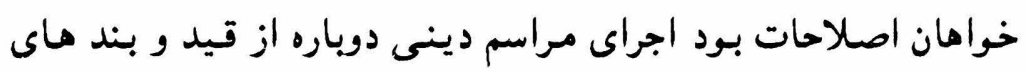
قبلى رهائى يافته است.

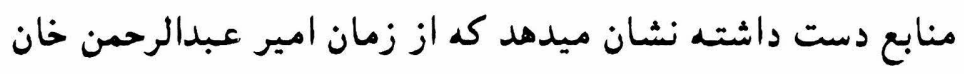


تا آخرين سالهاى سلطنت امير حبيب الله خان قزلباشها و در مجموع اهل تشيع تحت فشار شديد قرار داشت.

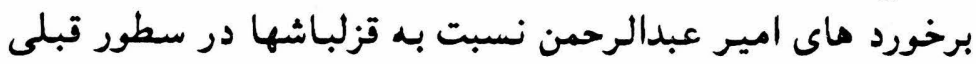

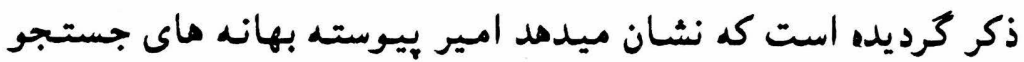

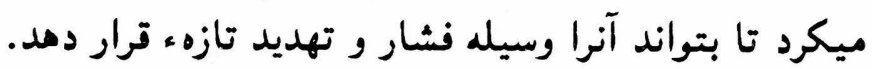

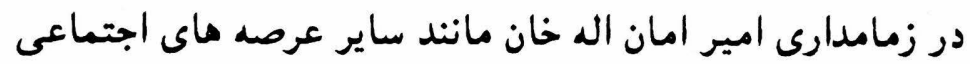

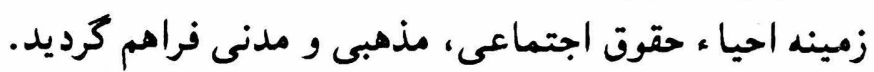

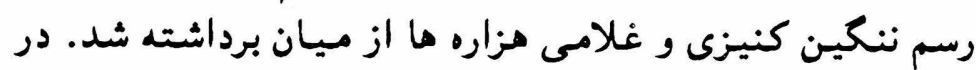

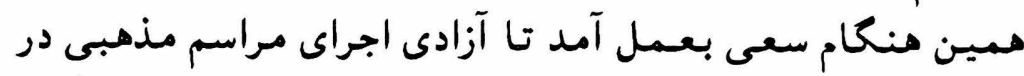

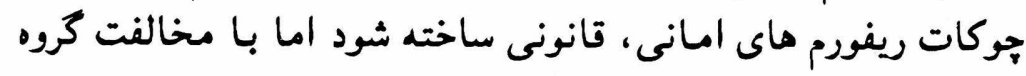
ماى محافظه كار مواجه شد.

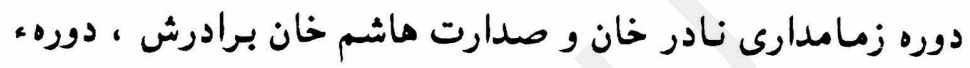

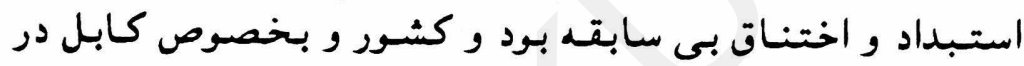

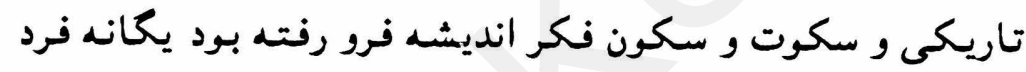

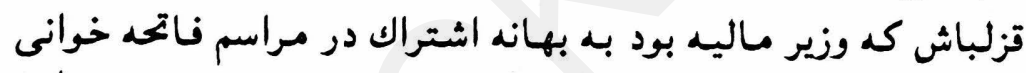

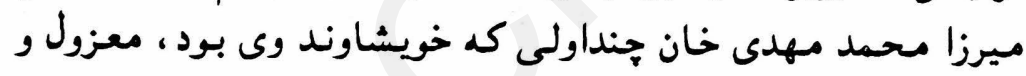

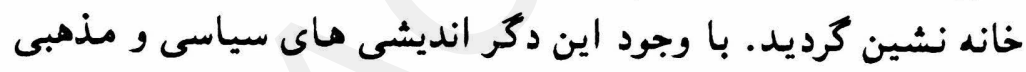

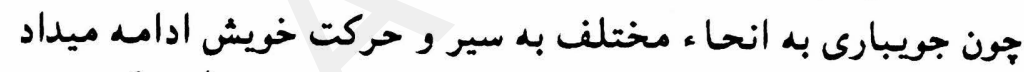

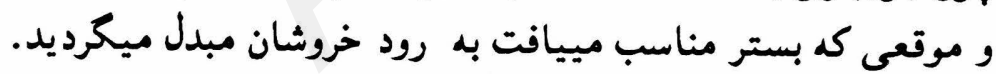

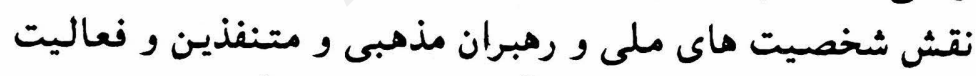

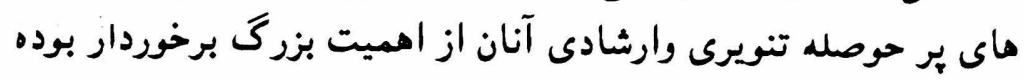

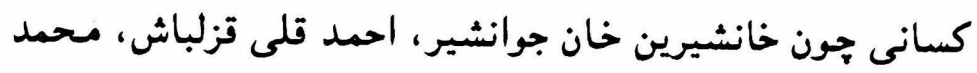

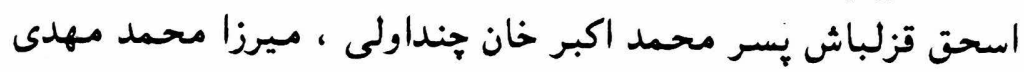

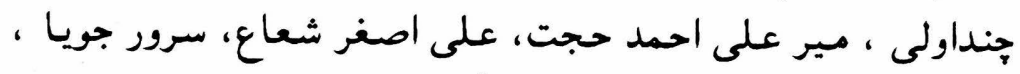

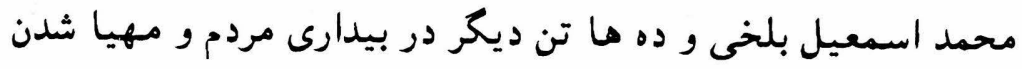


شرايط و زمينه ماى فكرى و اجتماعى اعاده حقوق و رعايت آزادى

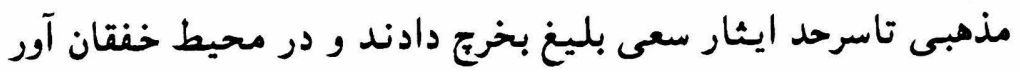

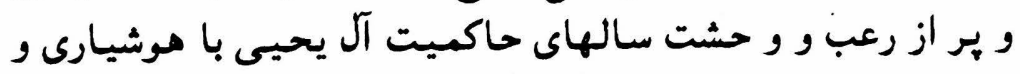

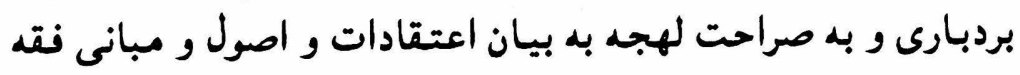
جعفرى برداختند.

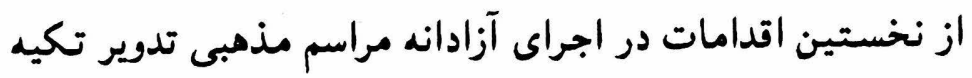

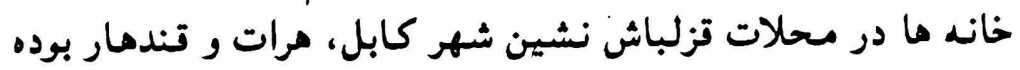
است.

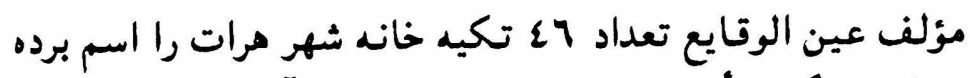

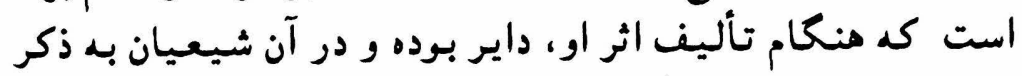

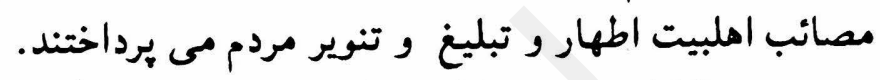

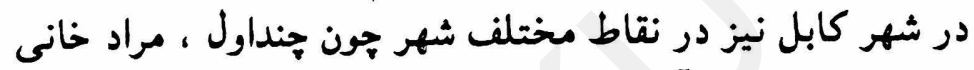

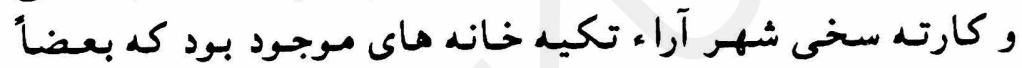

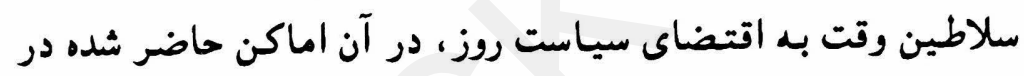

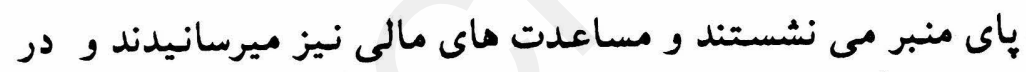

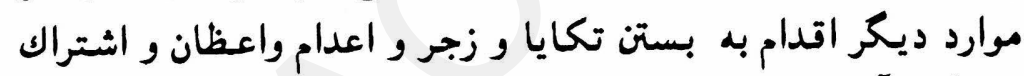

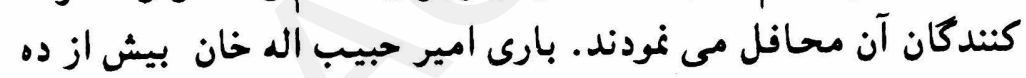

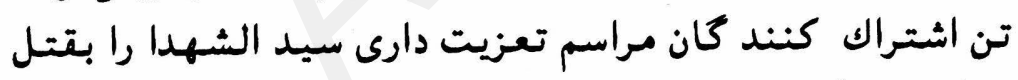

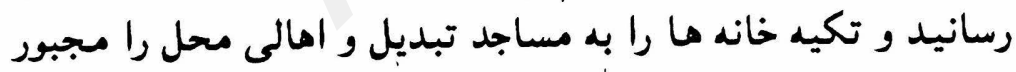

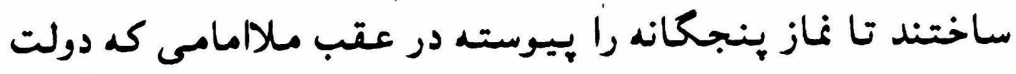
تعيين نموده بود اداء منايند.

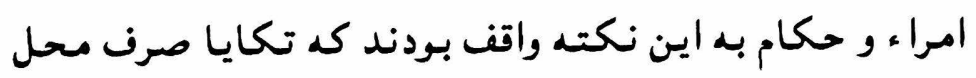

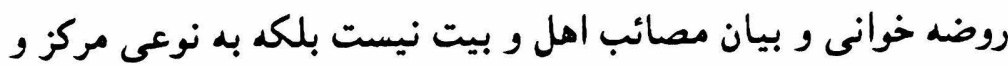

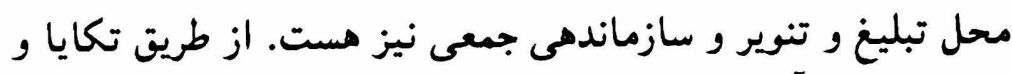

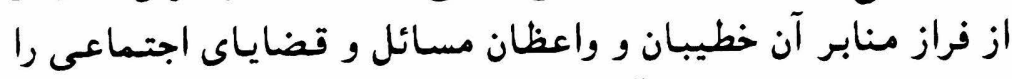

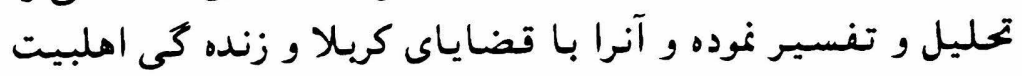


يبيوند ميدادند تا بر احساس و عواطف مردم تأثير بيشتر وارن نموده

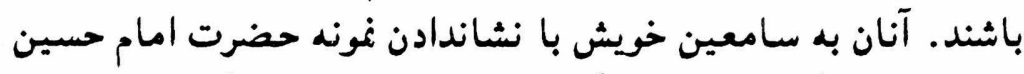

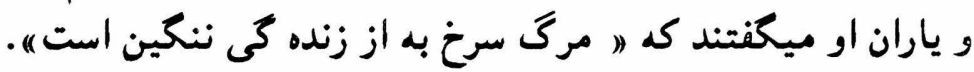

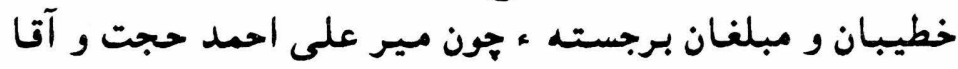

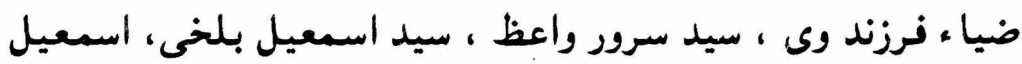

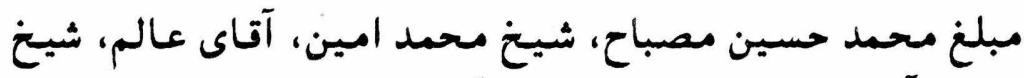

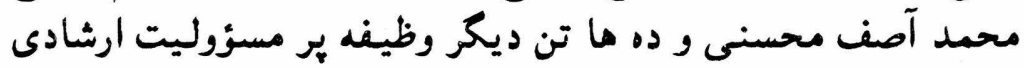
و تنويرى را بيش مى بردند.

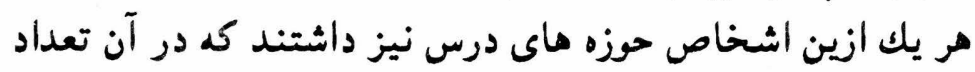

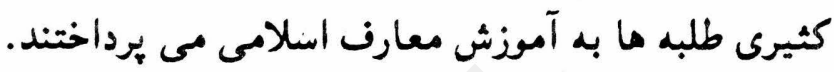

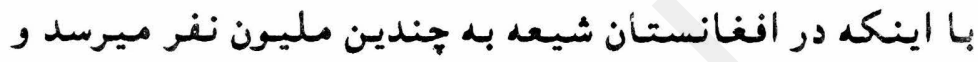

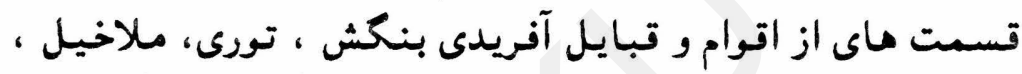

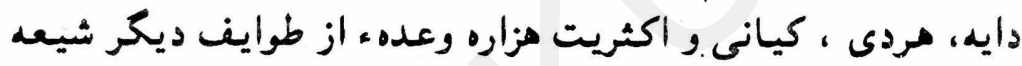

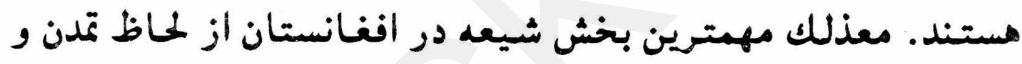

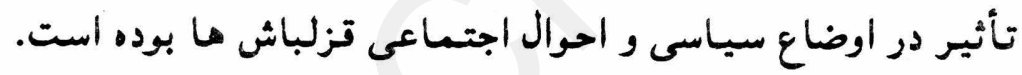

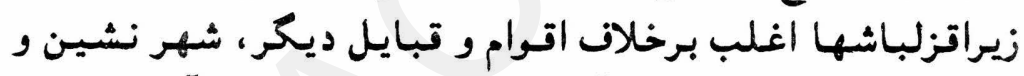

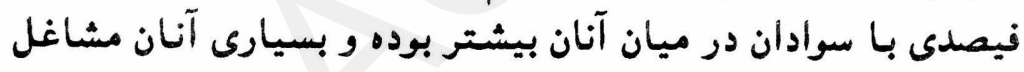
دولتئى داشته اند.

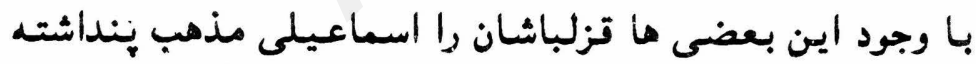

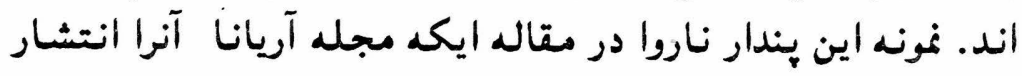

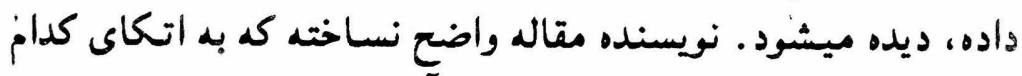

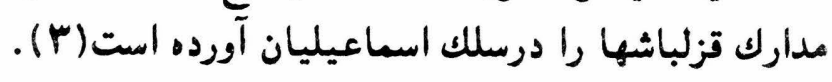

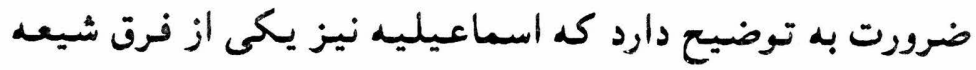

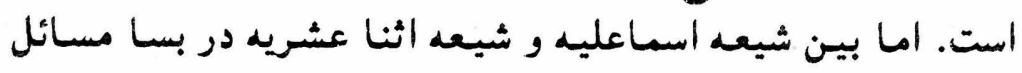
اختلاف وجود دارد. شيعه اسماعيليه كه به شيعه هفت امامى نيز شهرت دارند بعد از 


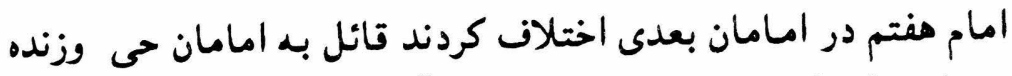

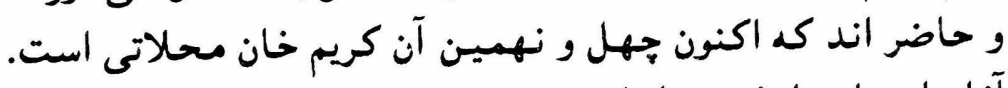

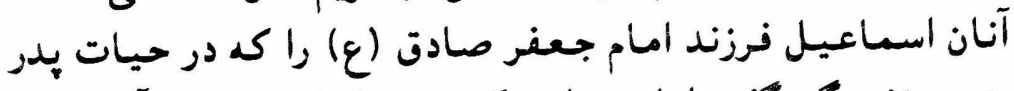

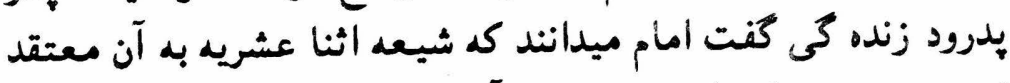

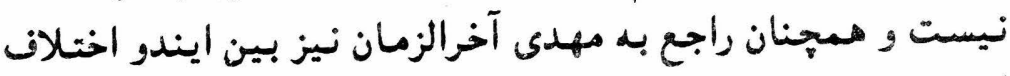
است

أننا عشريد قايلند بر اينكه آن مهدى موعود كه بشارت ظهورش

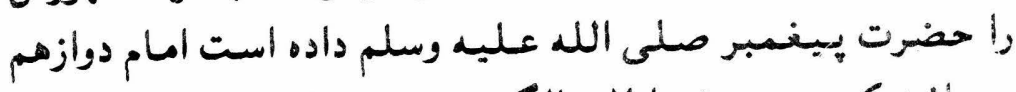

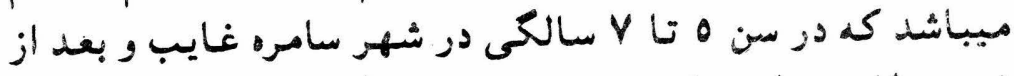

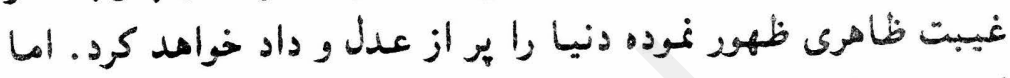

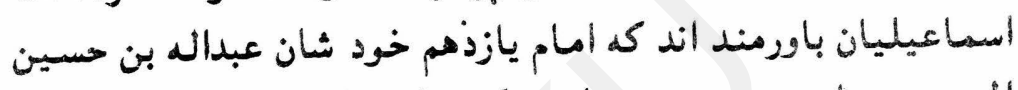

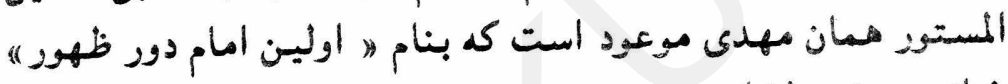
خوأنده ميشود (ع)

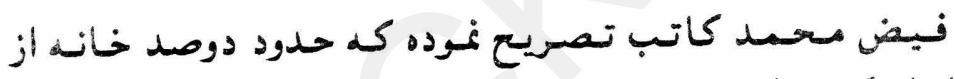

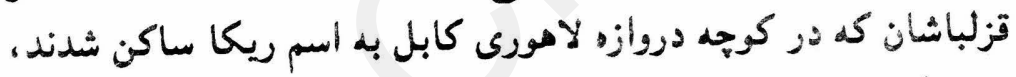

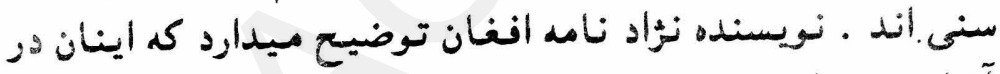

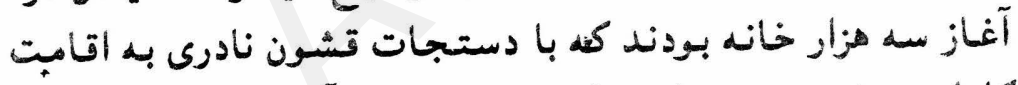

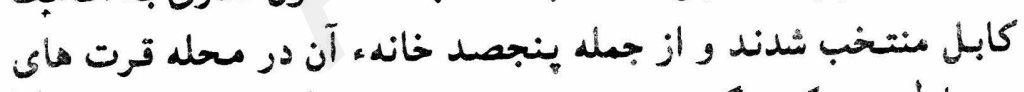

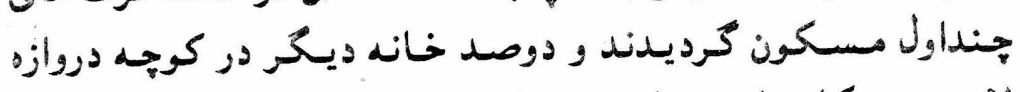

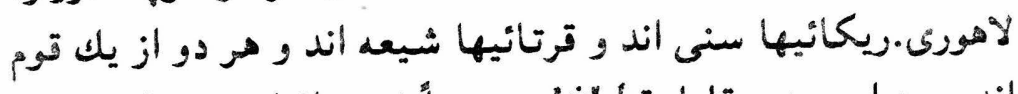

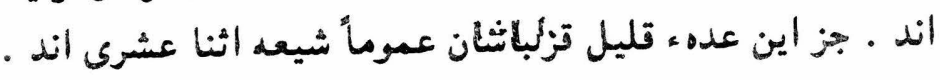

\section{وو فتوى ورباره تشيح}

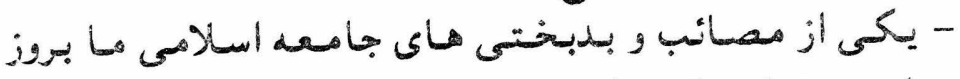

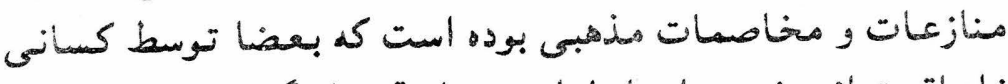

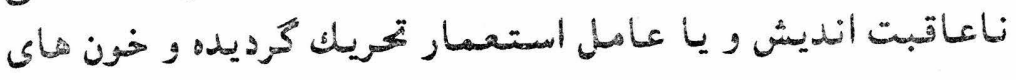


فراوان از هر دو جانب تشيع و تسنن به زمين ريخته است.

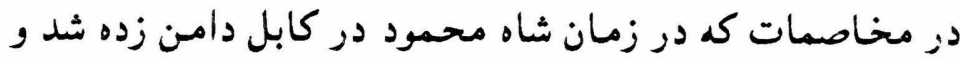

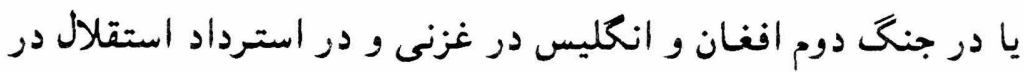

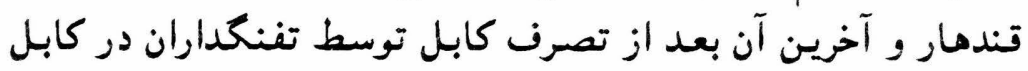

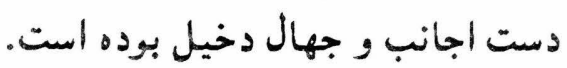

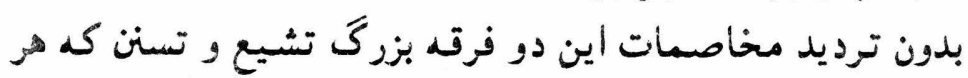

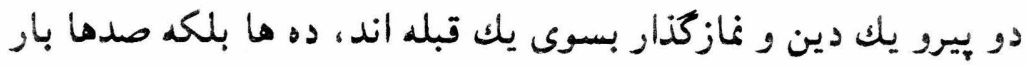

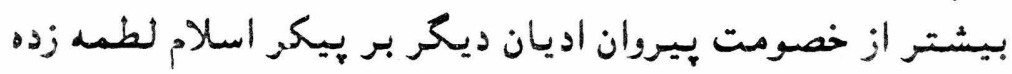

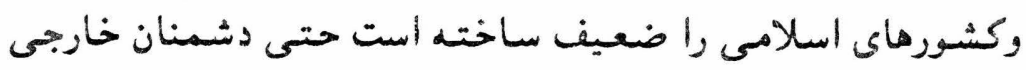

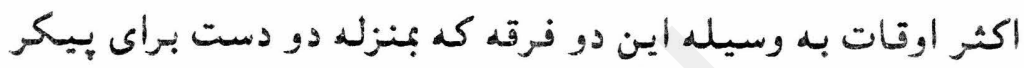

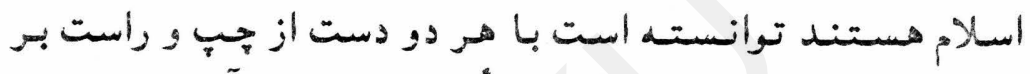

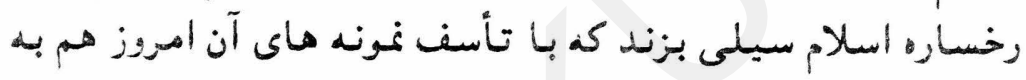

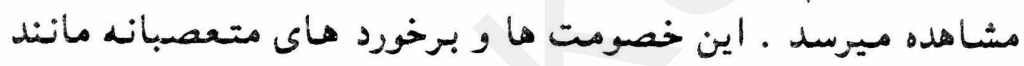

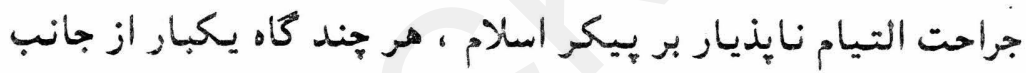
بيكانكان تازه ميكردد.

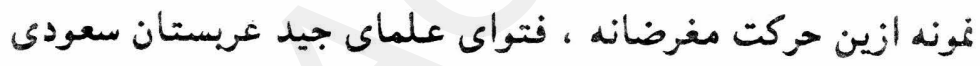

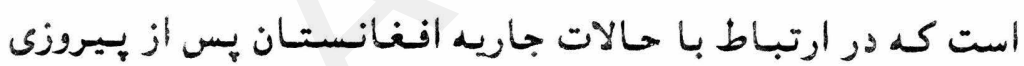

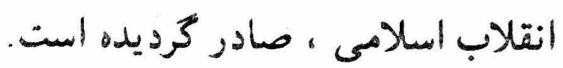

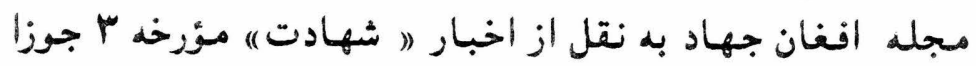

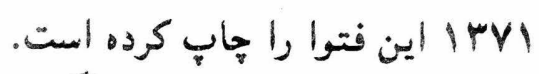

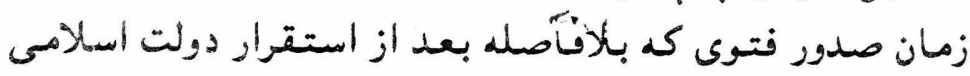

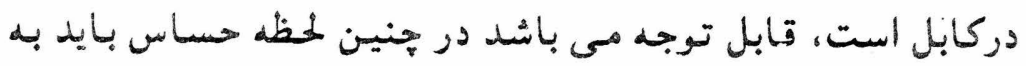

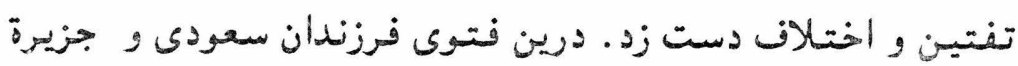

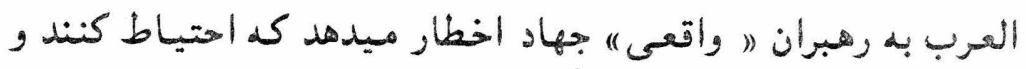

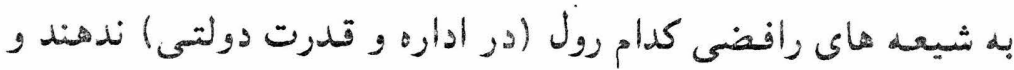

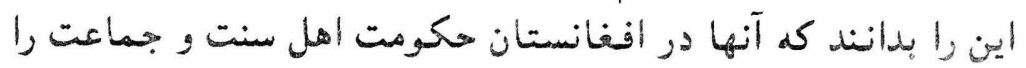


قبول كرده نميتوانند... (0) تو خود حديث مفصل بخوان ازين مجمل.

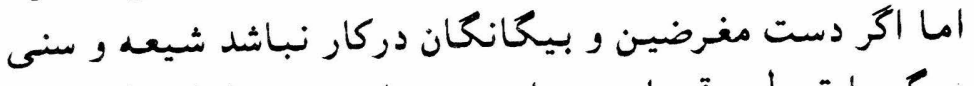

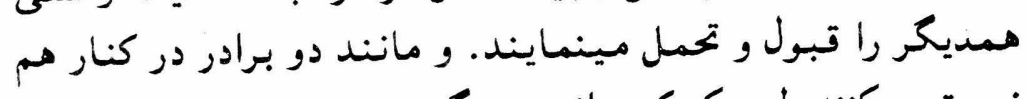

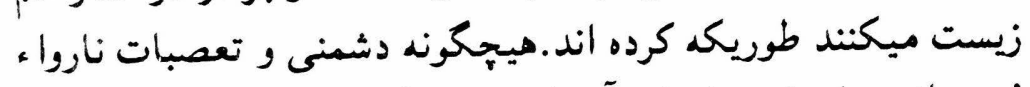

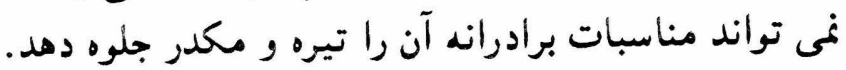

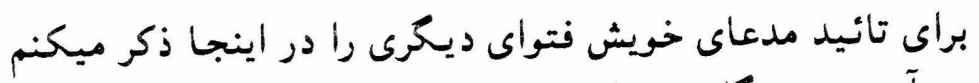
كه در آن دست بيكانه دخيل نيست.

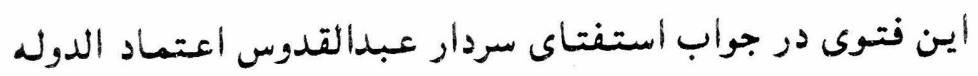

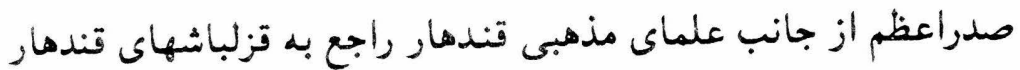

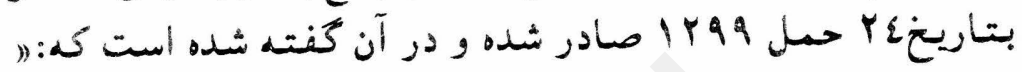

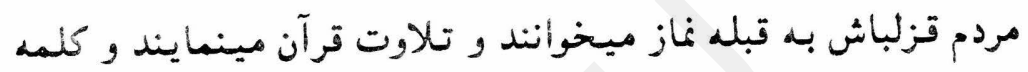

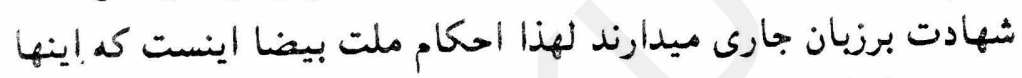

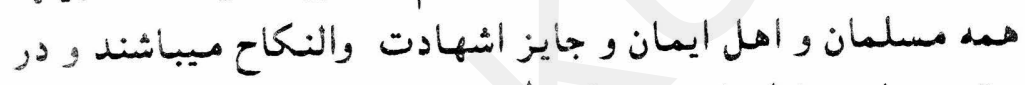

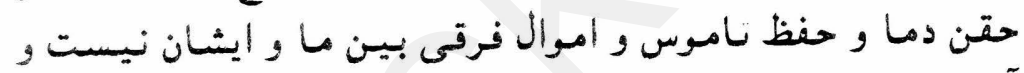

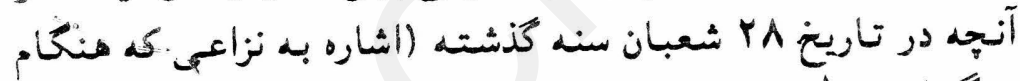

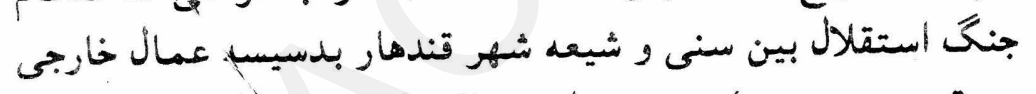

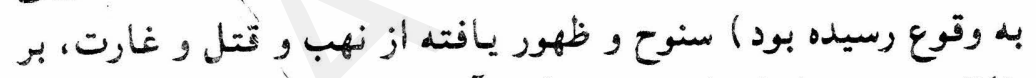

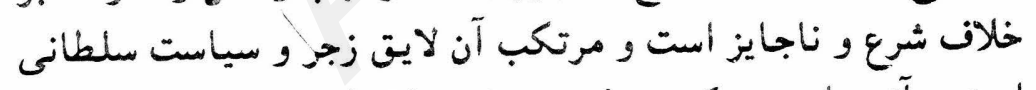

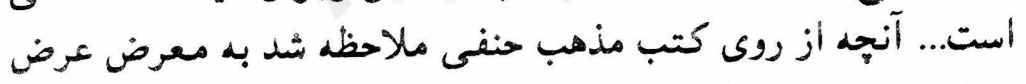
) رسانيده شد. ") (1)

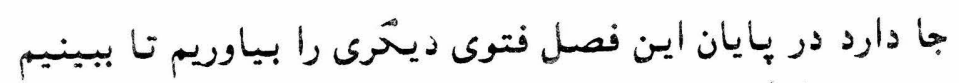

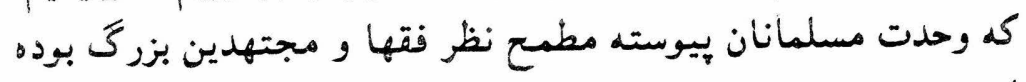

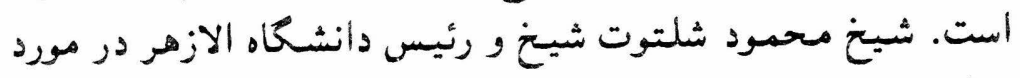

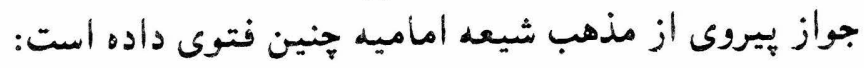

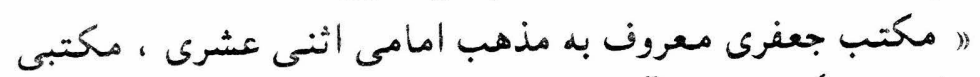

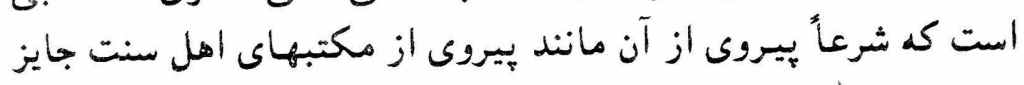




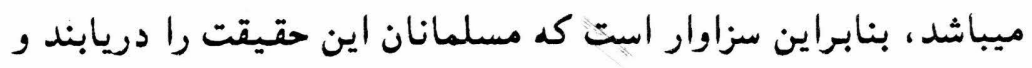

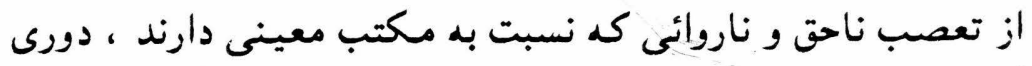

كزينتد.

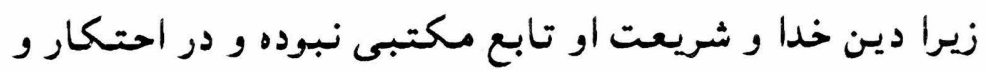

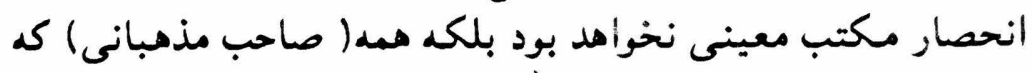

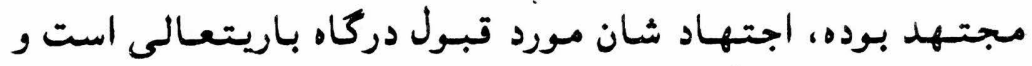

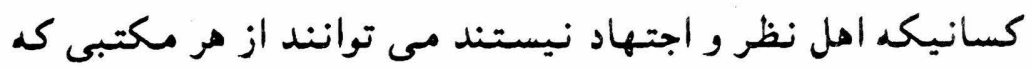

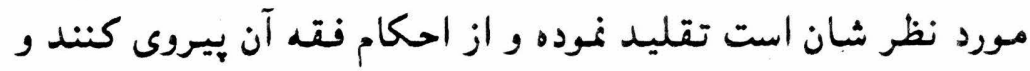

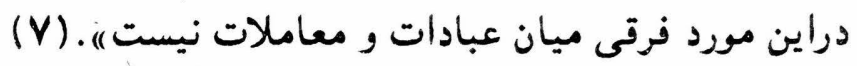

va 
مآخذ اين بخش

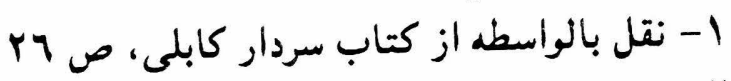

r-r

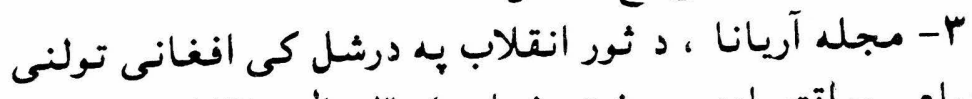

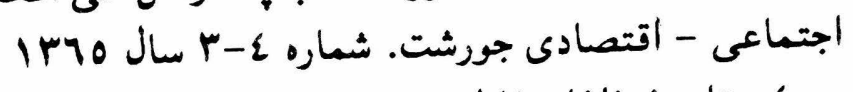

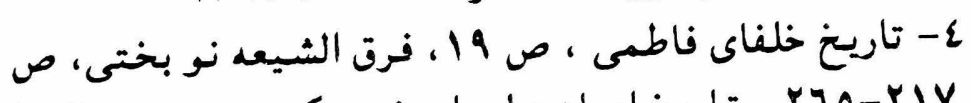

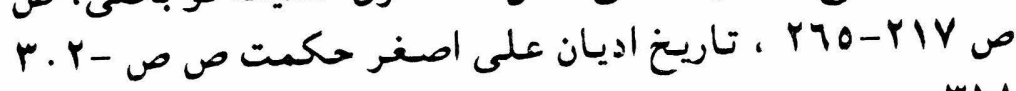

، MIA

ه- افغان جهاد

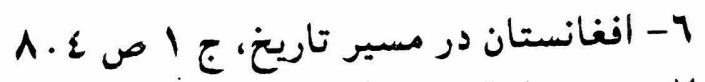

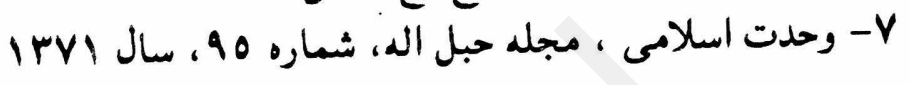

$\wedge$. 


$$
\text { فرهنح و شرايط اقتصادى - اجتماعى: }
$$

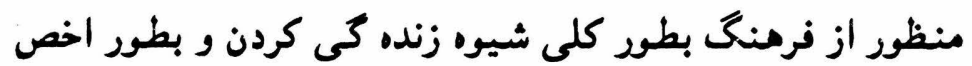

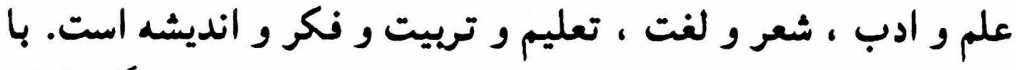

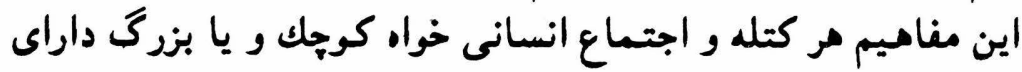
فرمنگ و اصالت فرمنكى است.

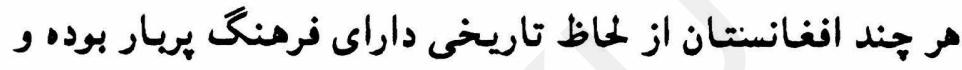

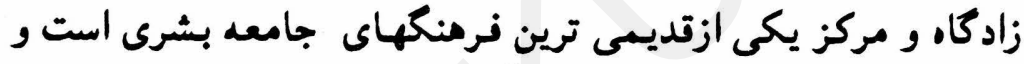

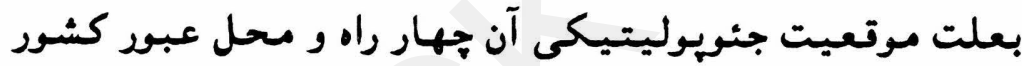

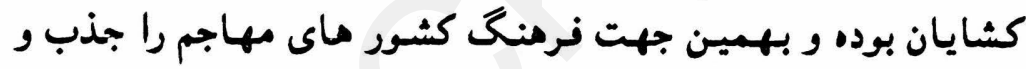

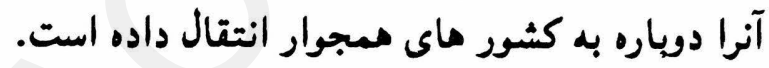

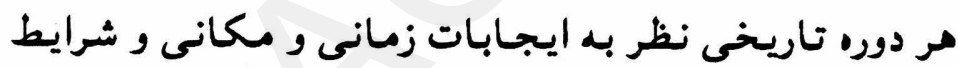

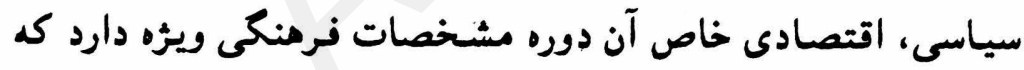

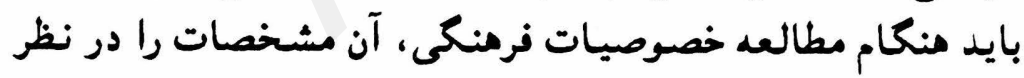

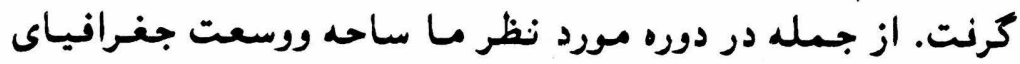

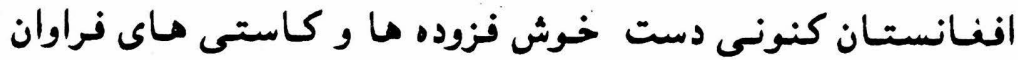

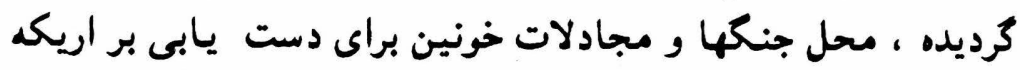

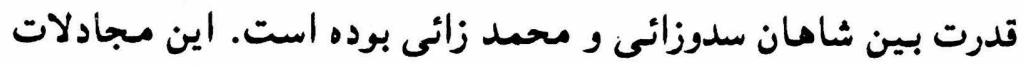

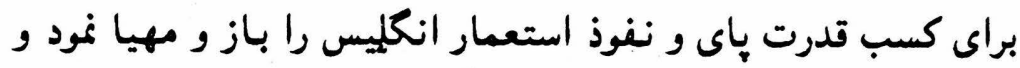

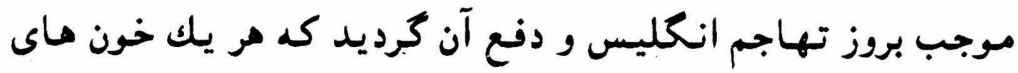

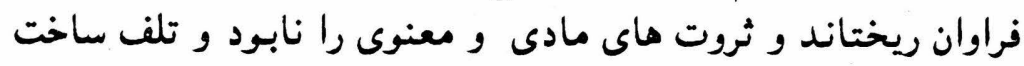




\section{و خود ركود فرمنكى را موجب كرديد.}

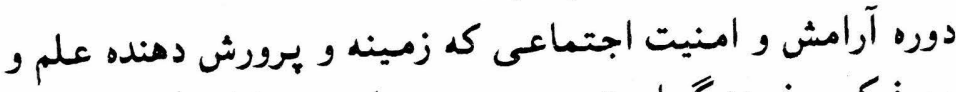

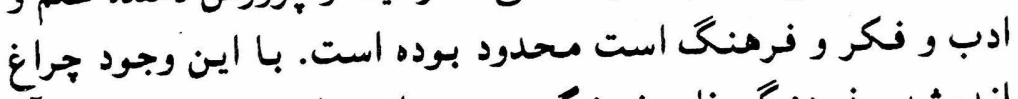

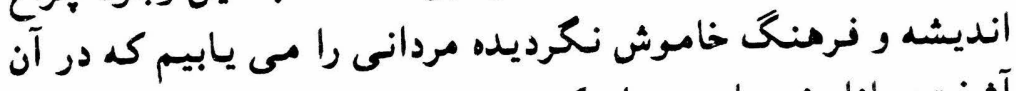

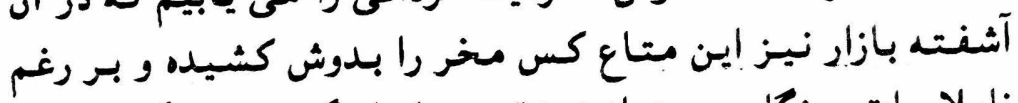

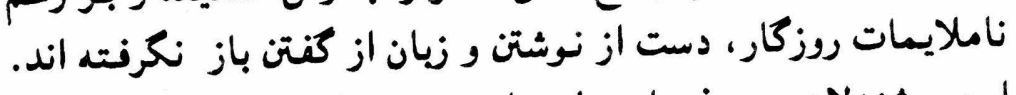

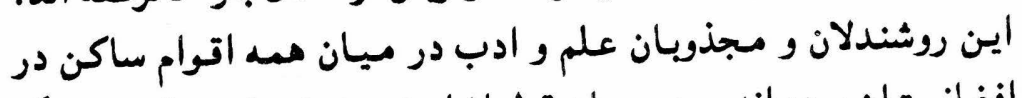

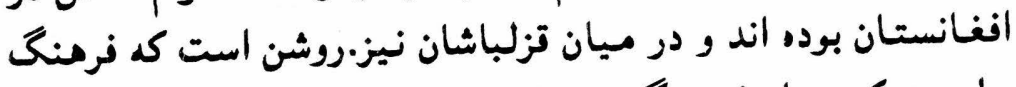

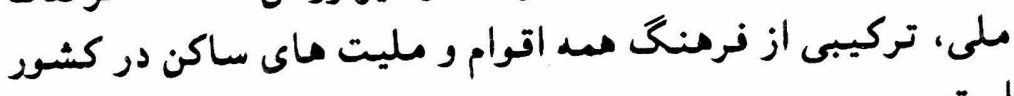

هر جند در كتب تاريخ كه طى دهد ماي اخير تأليف و انتشار

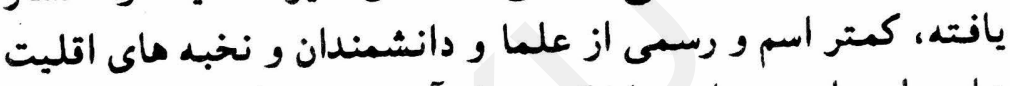

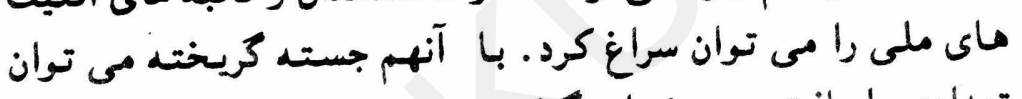

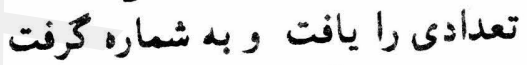

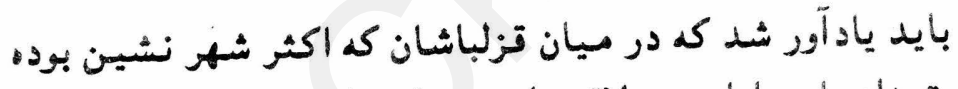

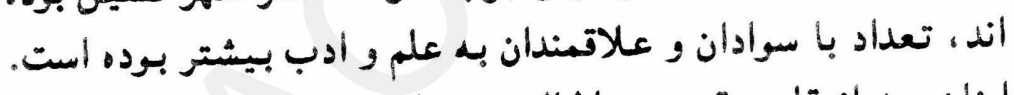

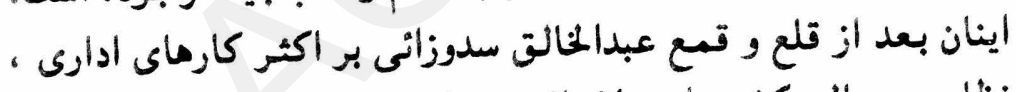

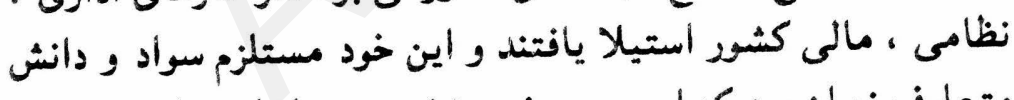

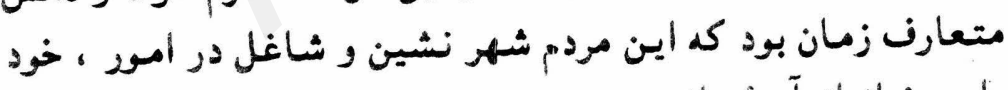

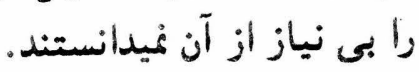

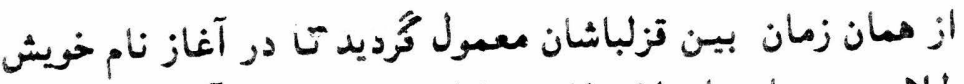

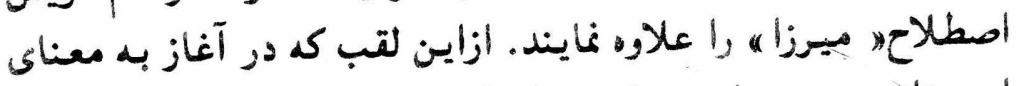

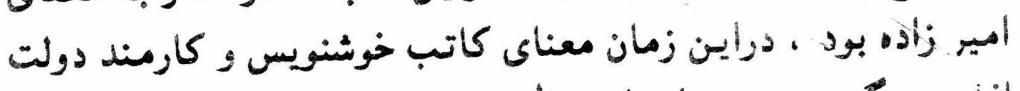

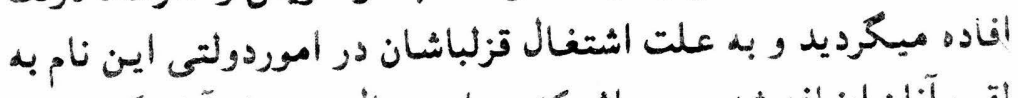

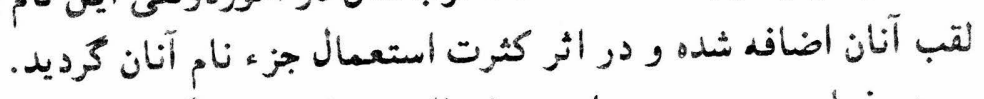

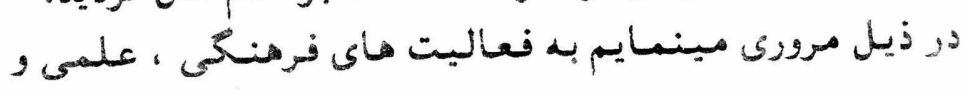


اجتماعى قزلباشان و مى بينيـم كد تا جه اندازه مى توان نقش بإى

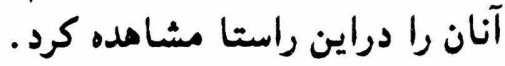

\section{تعليم و مسُغوليت هاى نكرى}

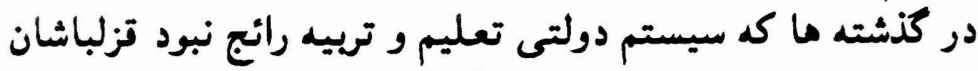

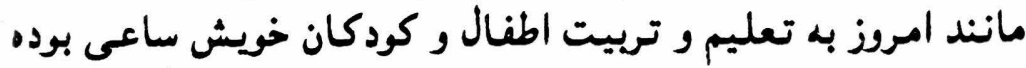

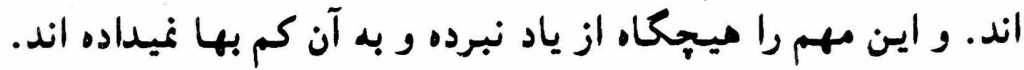

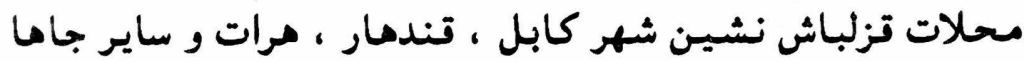

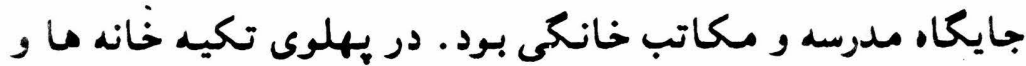

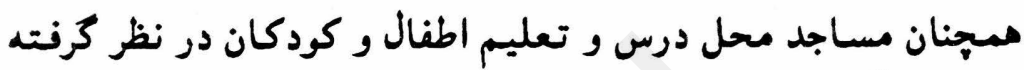

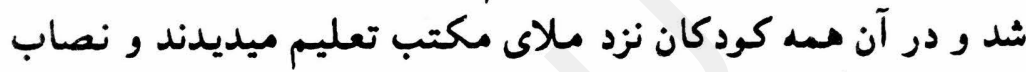

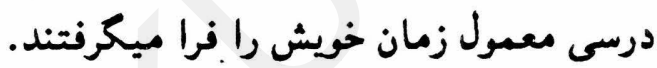

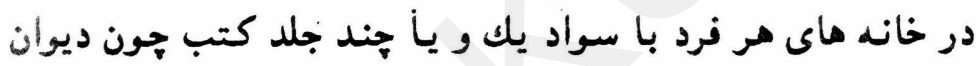

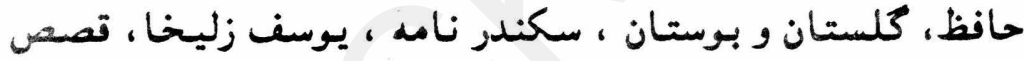

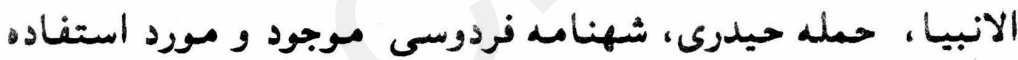

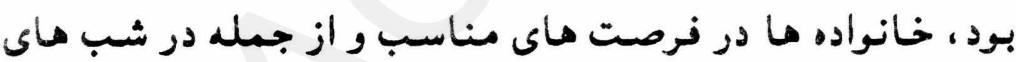
زمستان از آن استفاده ميبردند.

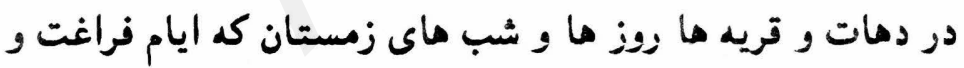

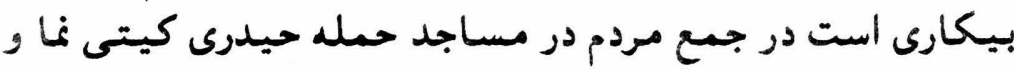

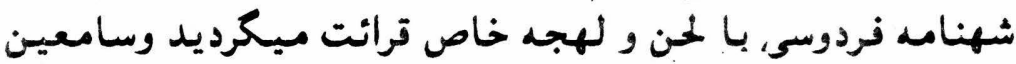

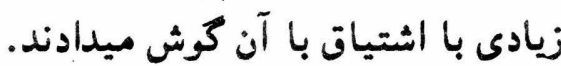

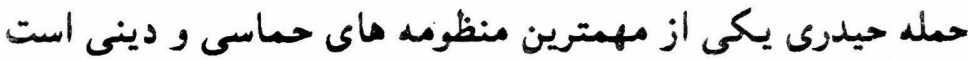

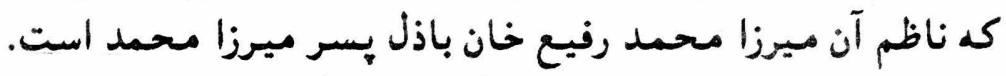

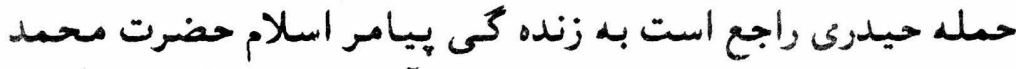

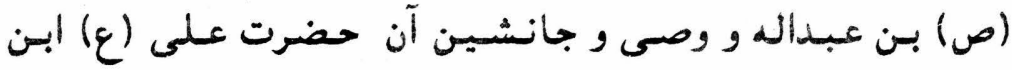

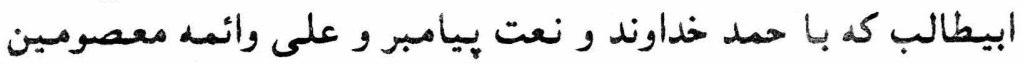


آغاز شده و بـه بعثت ييامبر و احوال آن حضرت و على بن ابيطالب

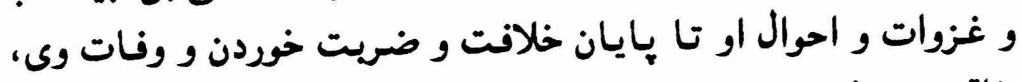
خاتمد مى هذيرد.

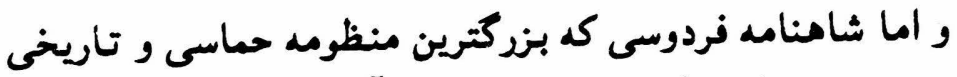

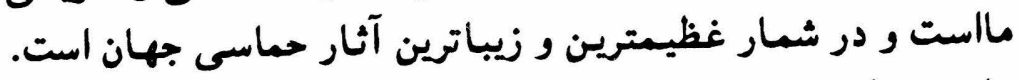

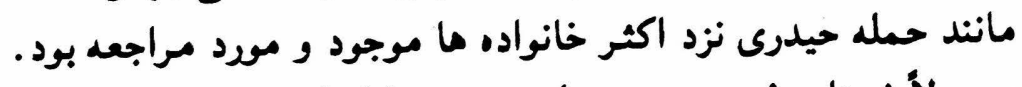

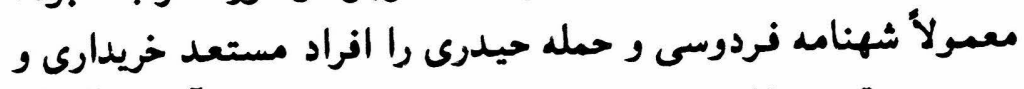

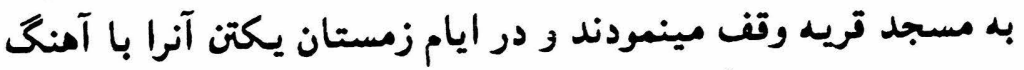

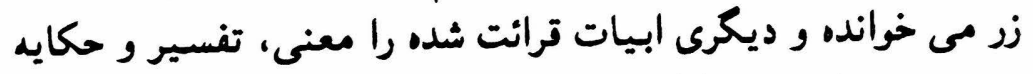

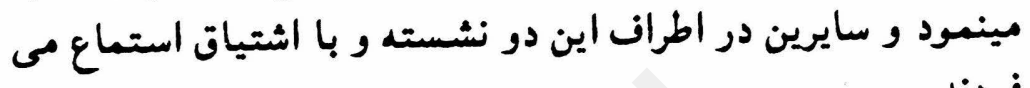
نمودند.

در مناطق قزلباش نشين ولايت غزنى تعداد زياد افراد بيسواد در

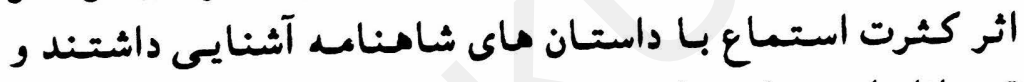

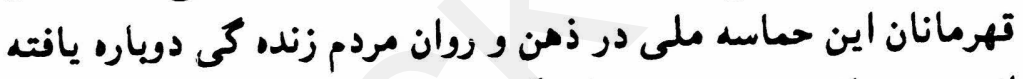
اند و مصداق سخن فردوسى كه كفته:

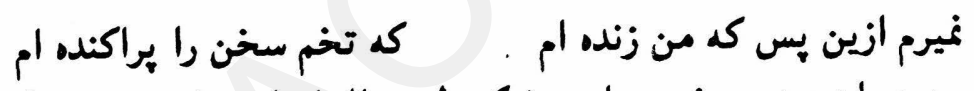

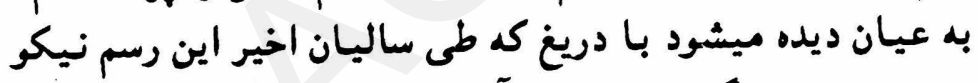

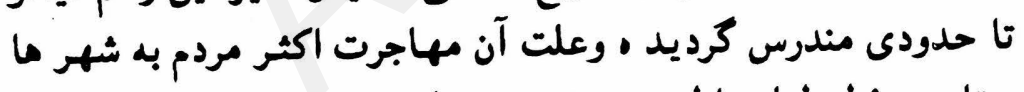

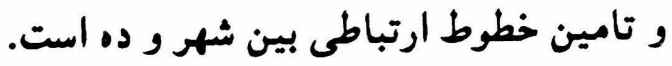

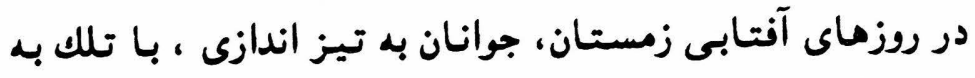

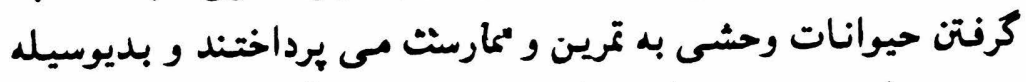

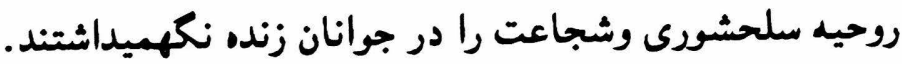

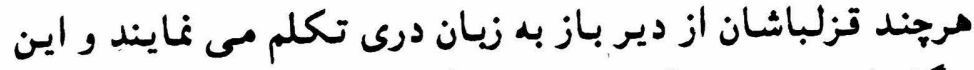

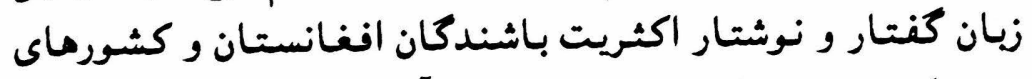

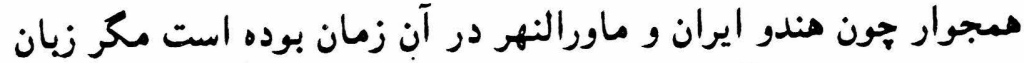

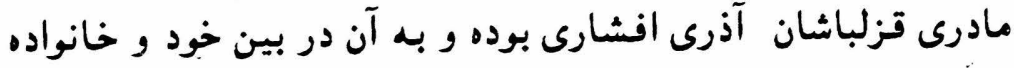


خويش محاوره و كفتكو مينموده اند.

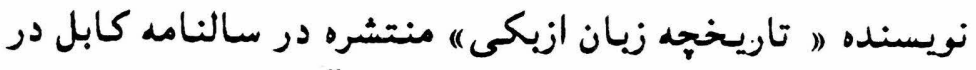

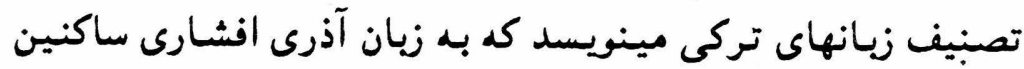

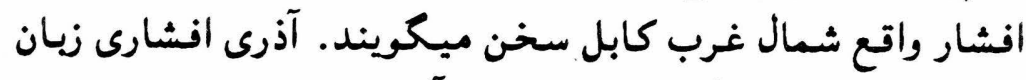

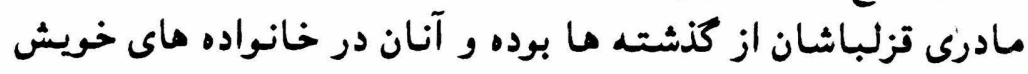

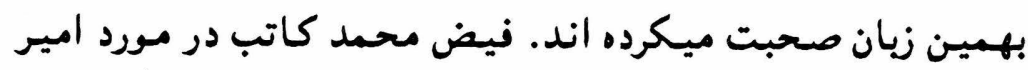

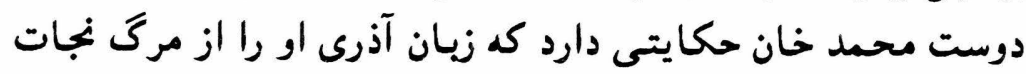
داده است.

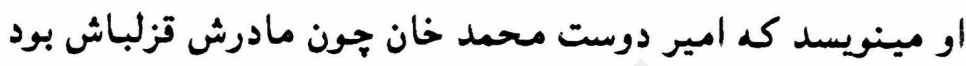

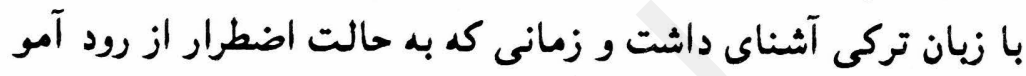

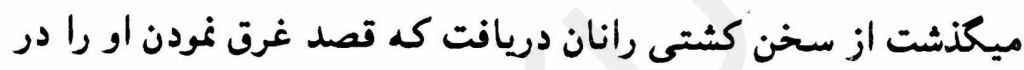

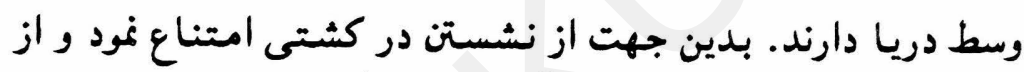

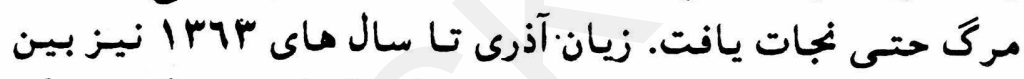

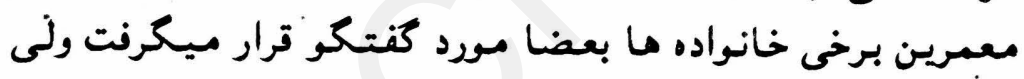

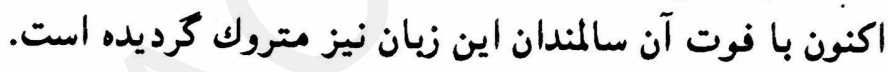

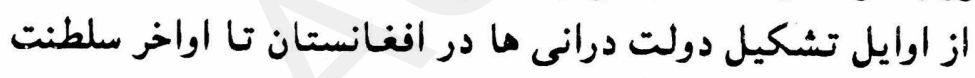
امير شير على خان به قول الفنستون فرامين شاه بـ به بزيان تركى اردي ارائه

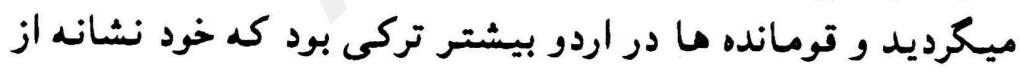

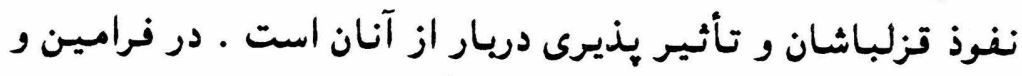

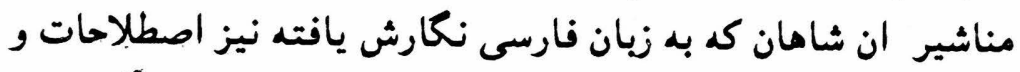

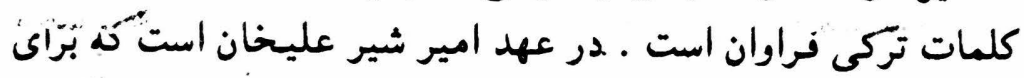

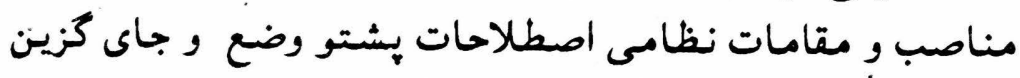

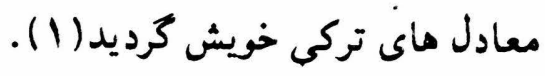

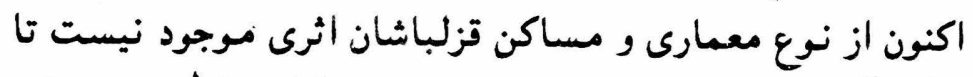

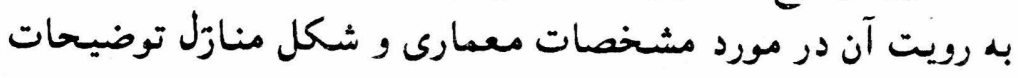

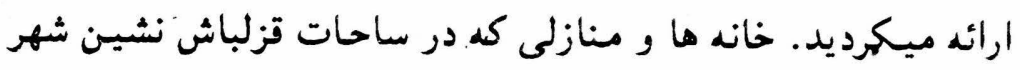


كابل وجود داشت مانند مراد خانى و جنداول مهه در نتيجه تطبيق

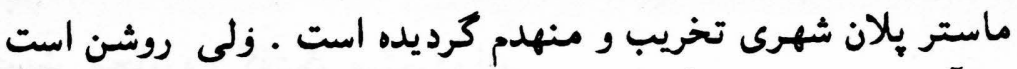

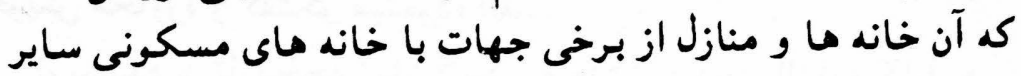

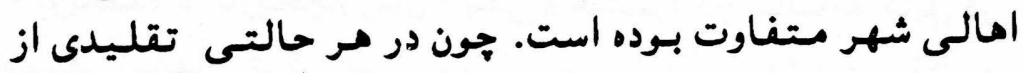

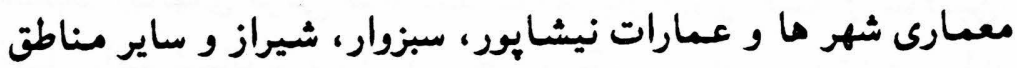

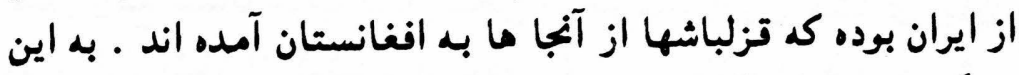

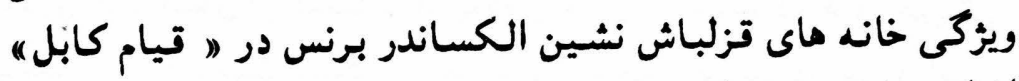

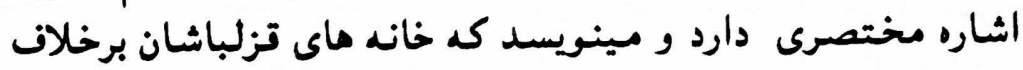

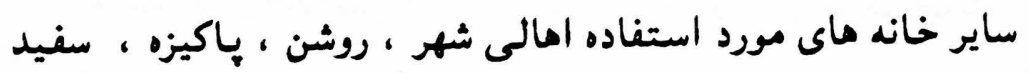
كارى ميباشد.

\section{صنايع دستى و مستظرفه:}

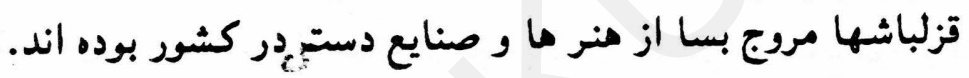

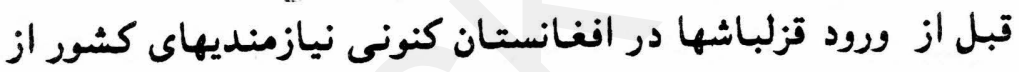

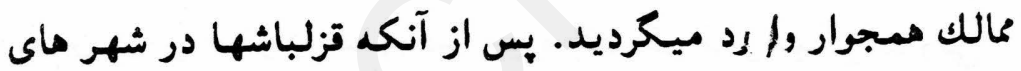

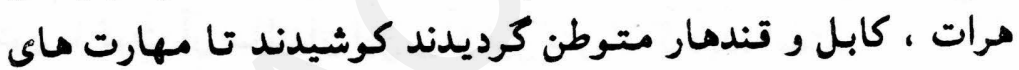

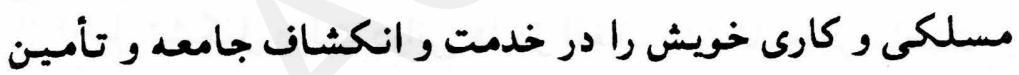

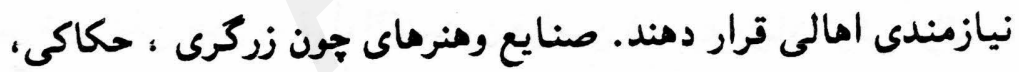

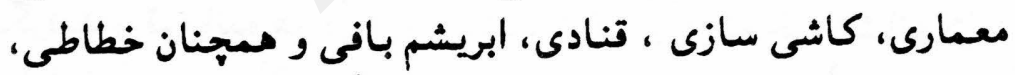

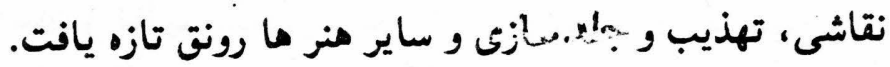

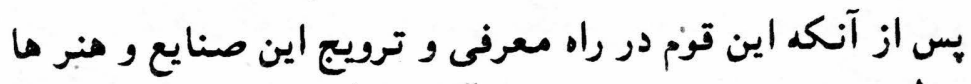

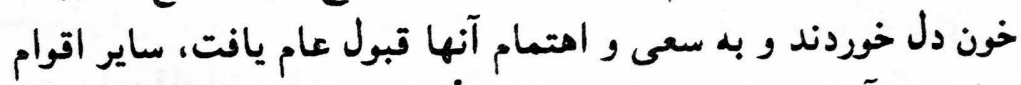

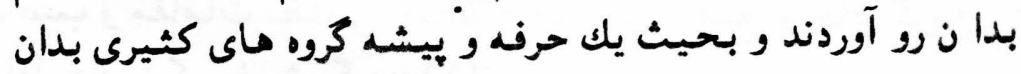

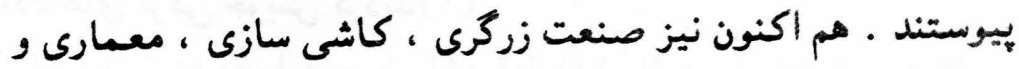

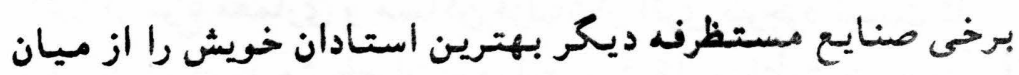


بعنوان نمونه به صنعت لنكى بافى يكلى از احتياجات عمومى

$$
\text { مردم مييردازيم. }
$$

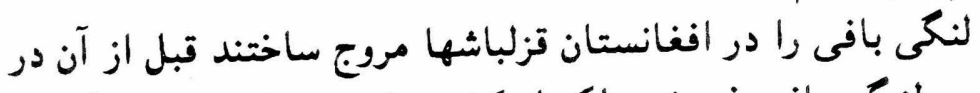

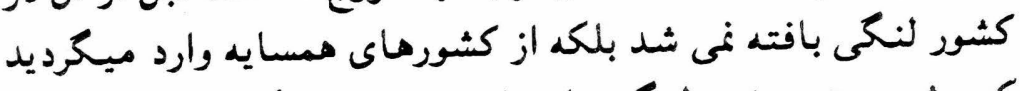

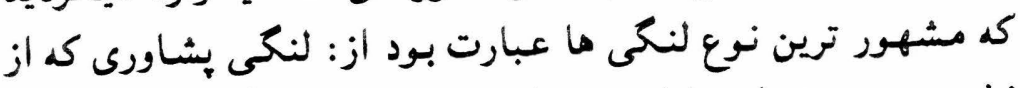

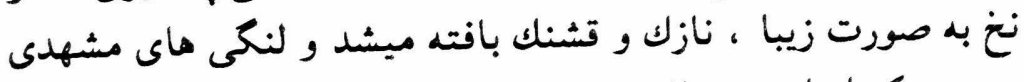

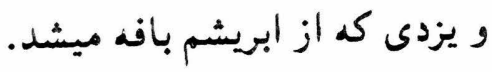

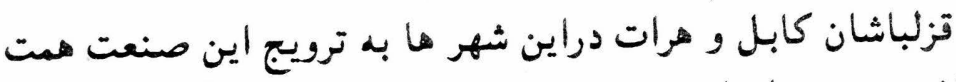

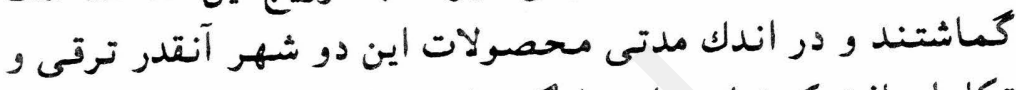

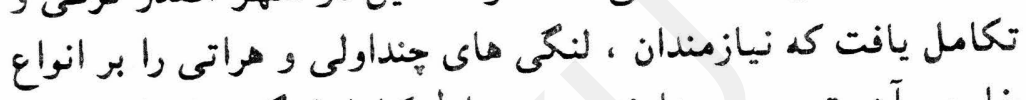

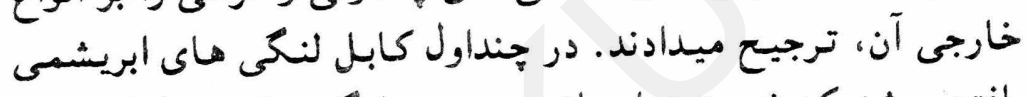

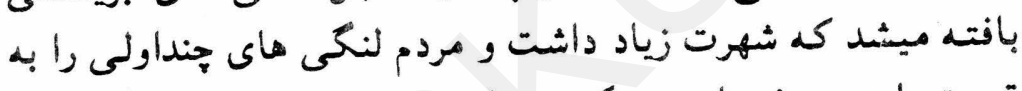

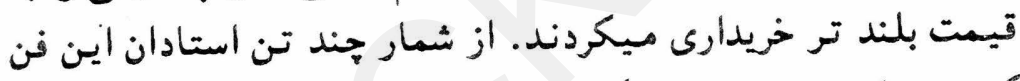

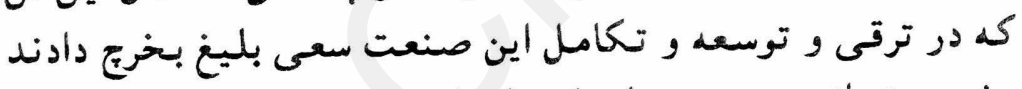

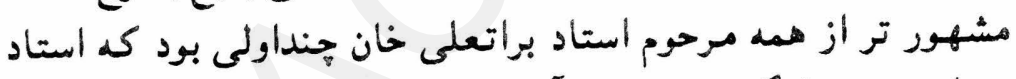

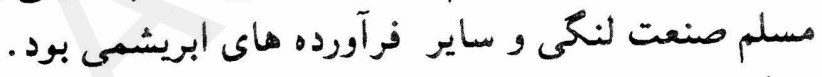

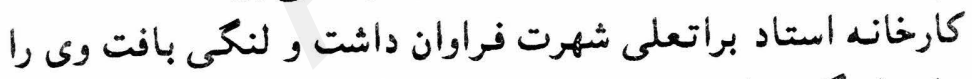

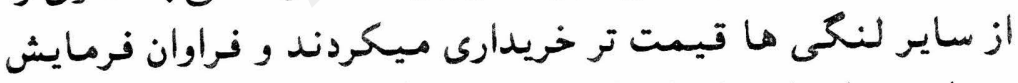

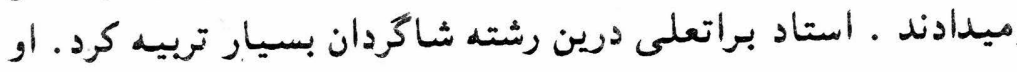

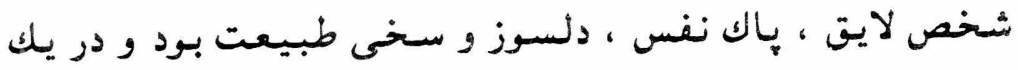

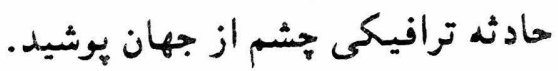

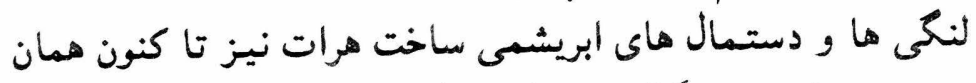

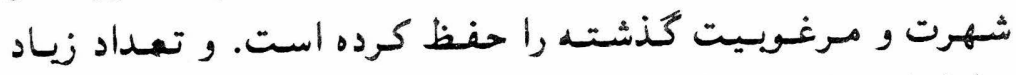

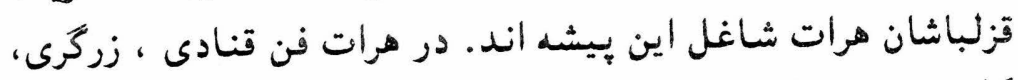

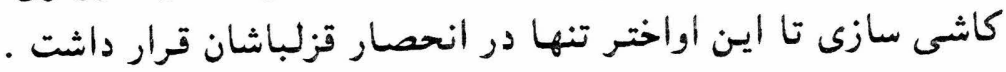


نمونه هاى كاشى سازى و كاشى كارى اين مردم را ميتوان در مسجد

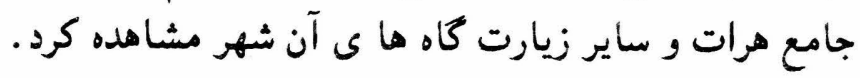

\section{طب ودوكتوران قزلباش:}

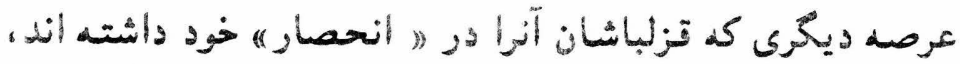

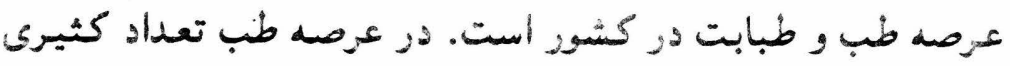

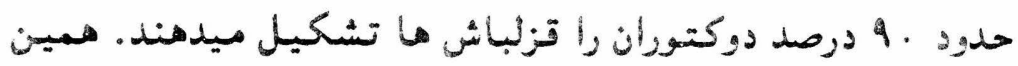

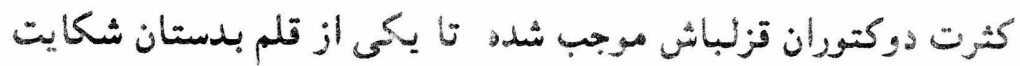

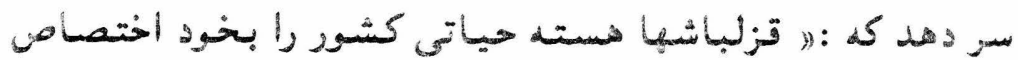

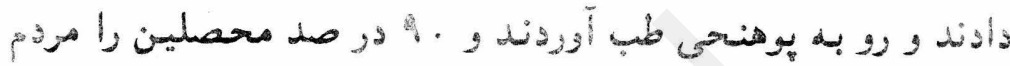

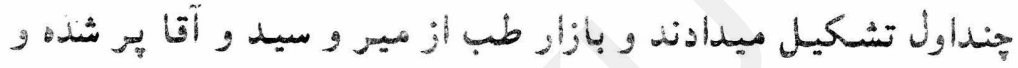

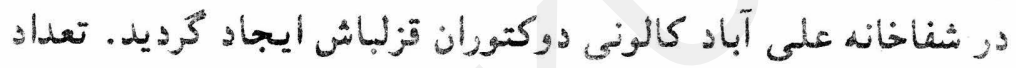

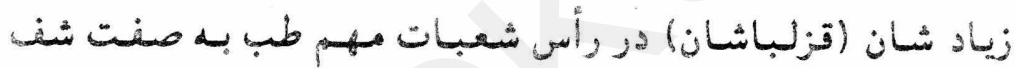

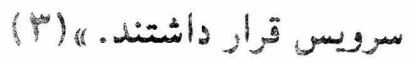

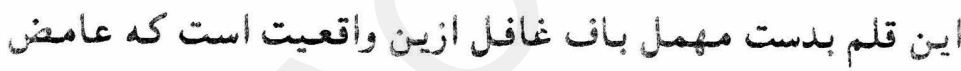

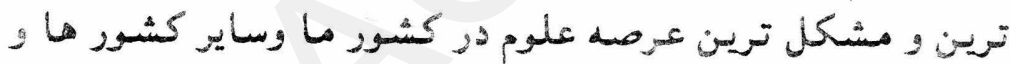

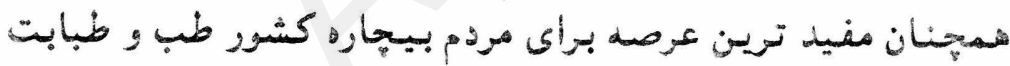

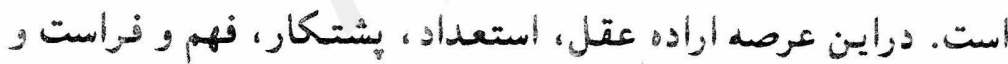

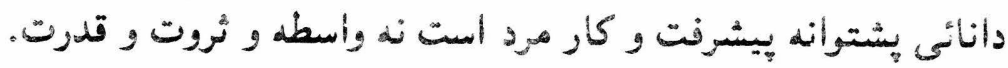

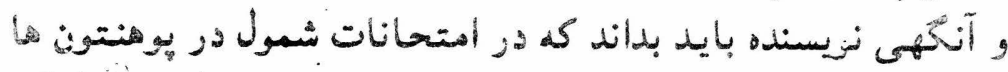

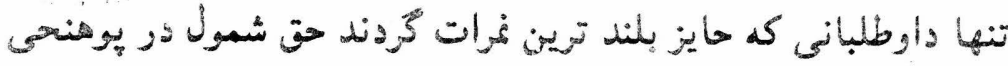

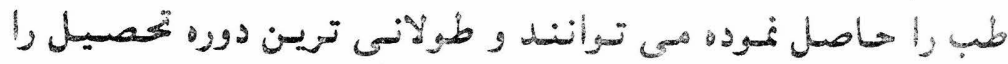

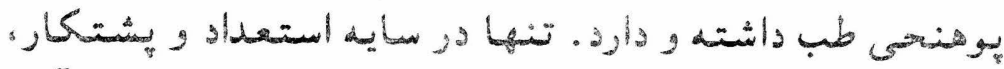

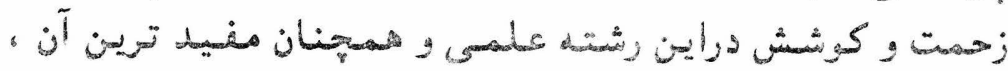

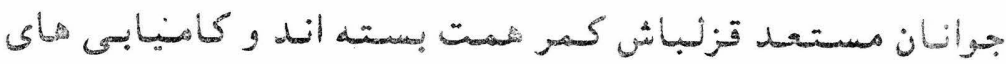

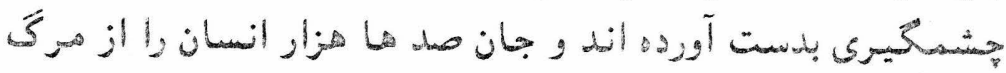


رهانيده و حيات دوباره بخشيده اند.

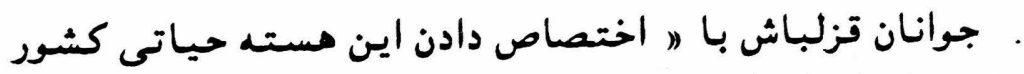

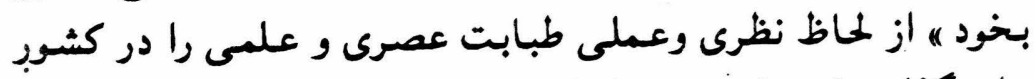

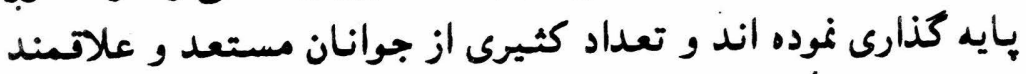

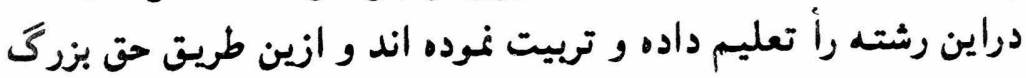

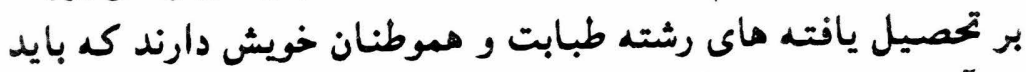

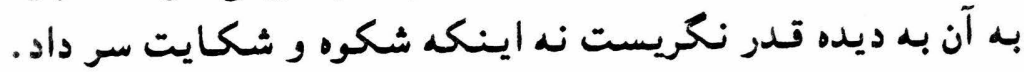

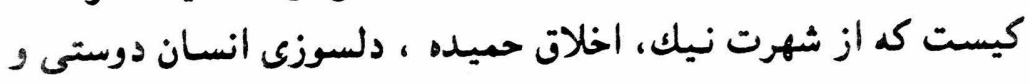

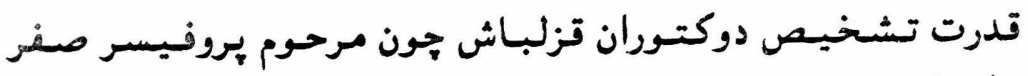

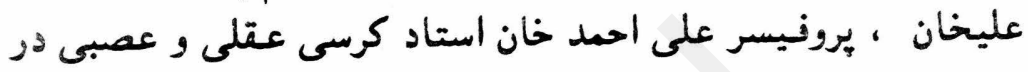

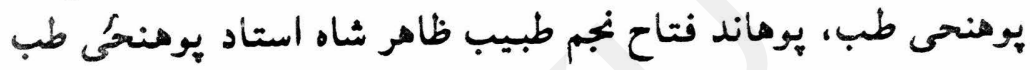

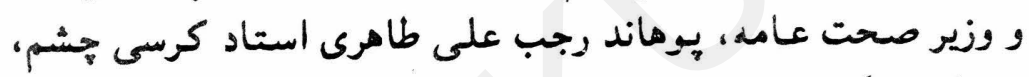

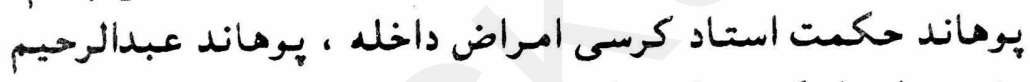

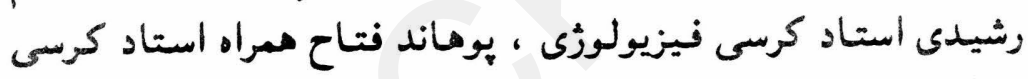

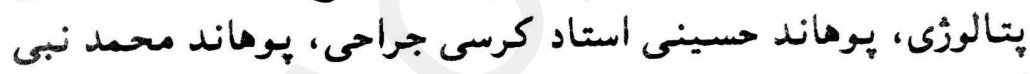

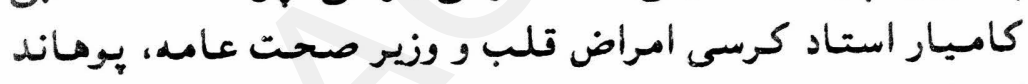

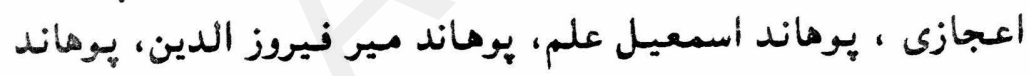

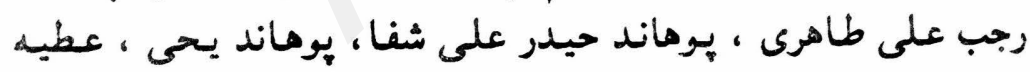

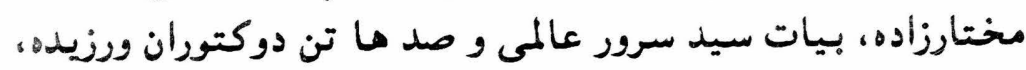

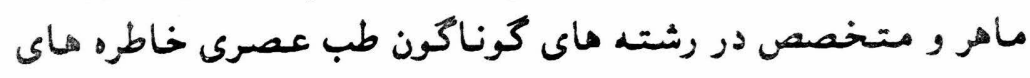

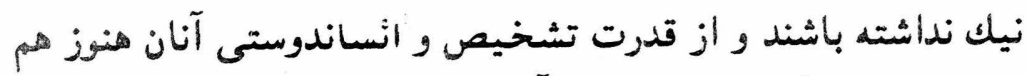

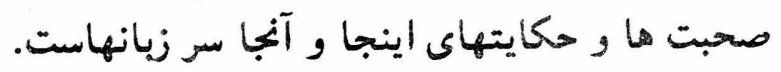

\section{مؤرخان وخطاطلان مشههور:}

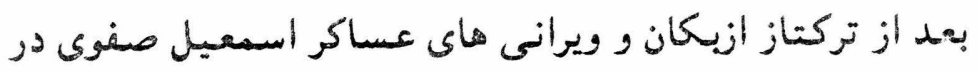

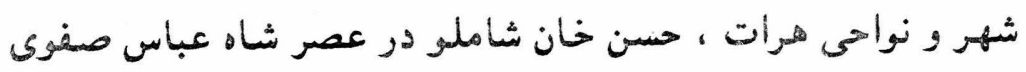


به بيكلر بيكى خراسان مقرر و بهرات آمد. حسن خان شاملو و

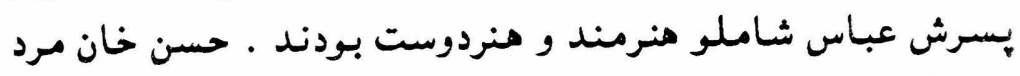

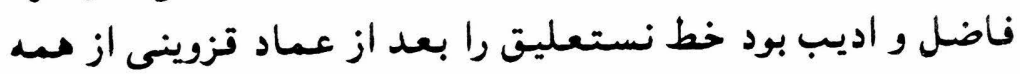

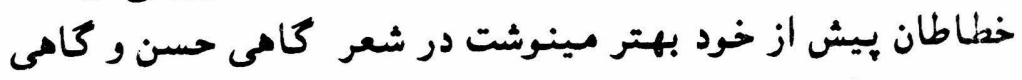

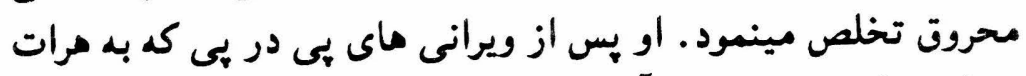

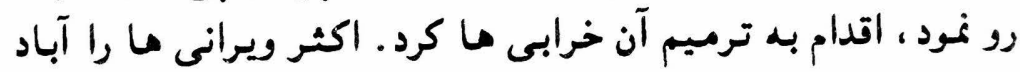

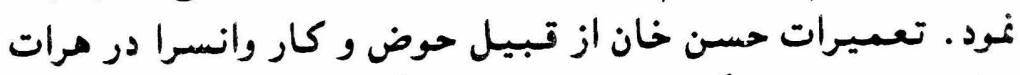

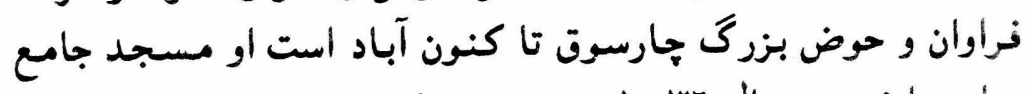

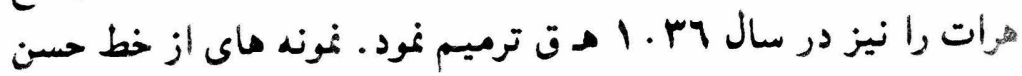

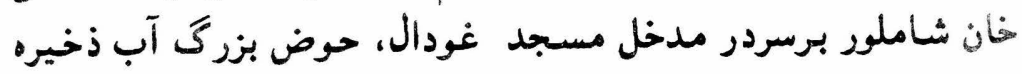

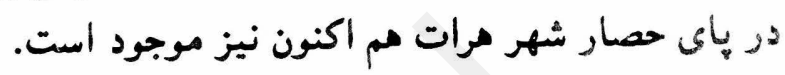

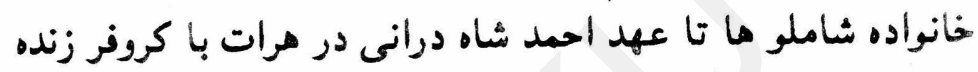

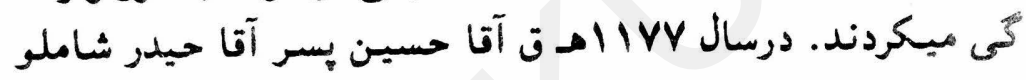

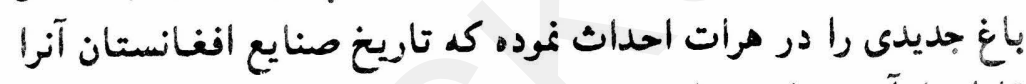
قابل ياد آورى دانست راند است هرات احداث

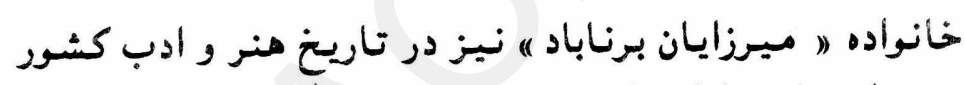

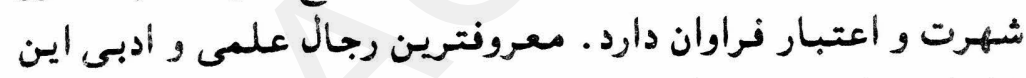

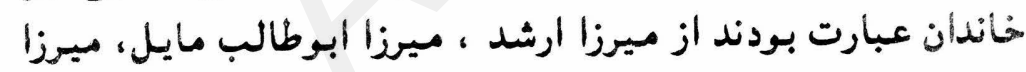

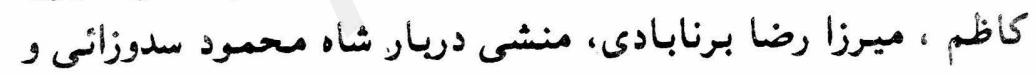

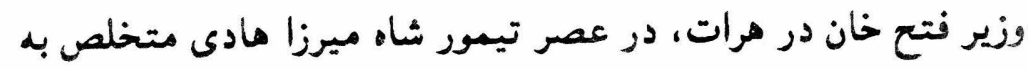

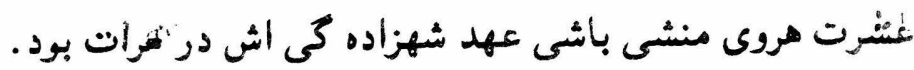

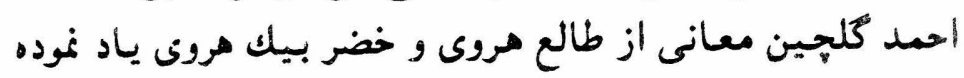

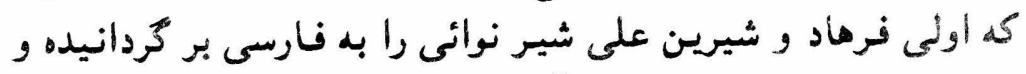

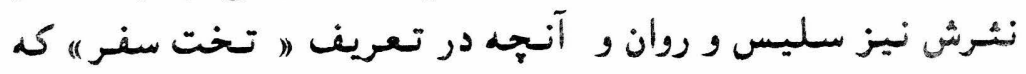

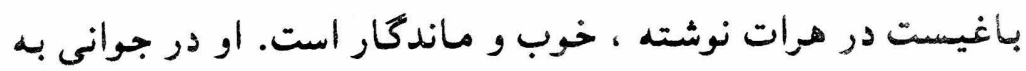

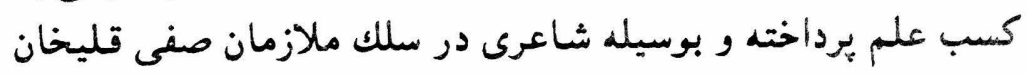




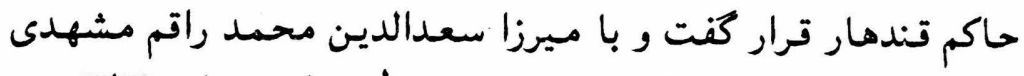

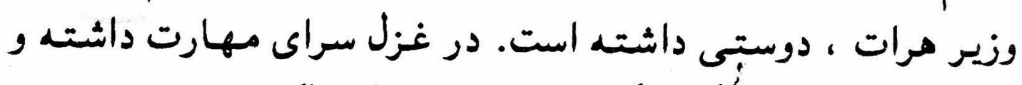

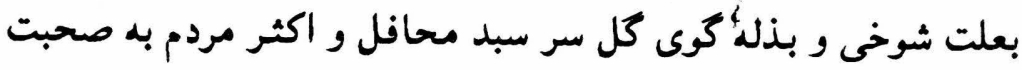

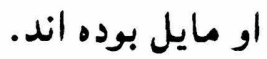

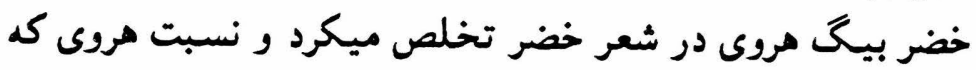

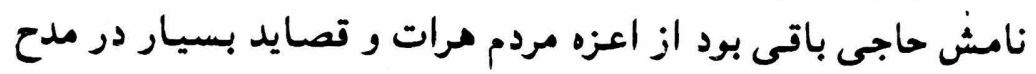

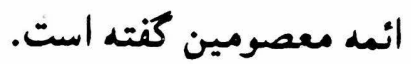

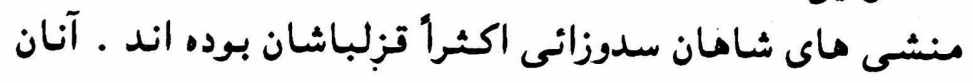

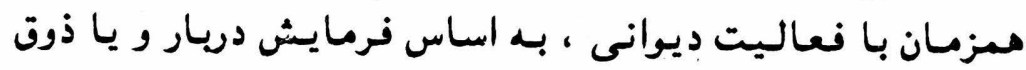

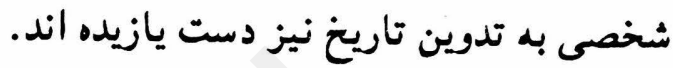

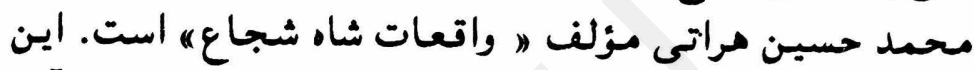

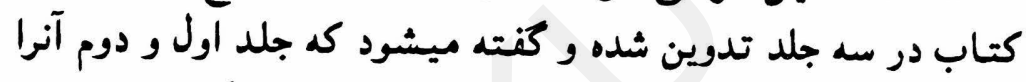

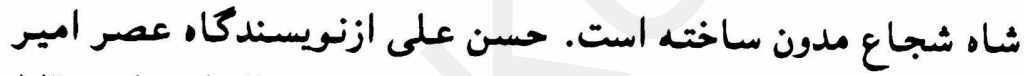

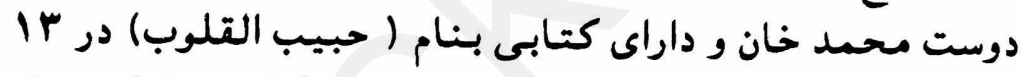

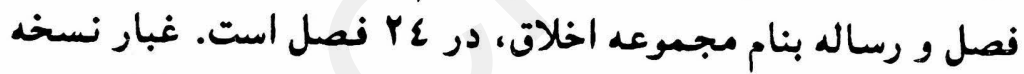

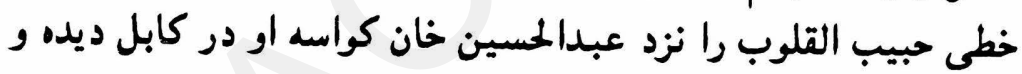
از آن در تاريخ ادبيات خويش ياد كرده است.

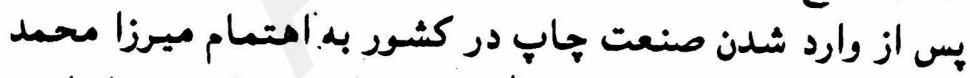

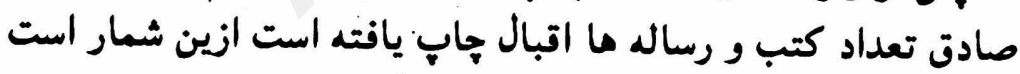
قانون نامه عسكرى ، حجت قويد در در ابطال عقايد ومابيه.

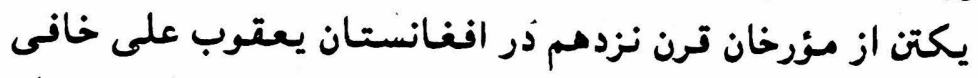

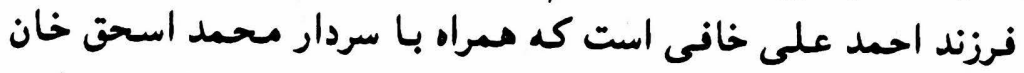

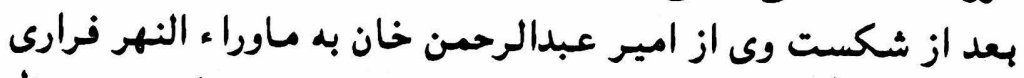

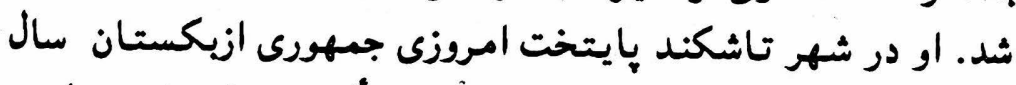

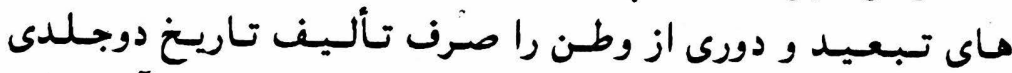

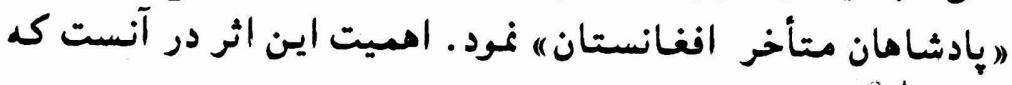


مؤلف خود ناظر قضايا و حوادئى بوده كد كتاب درباره آن بحث

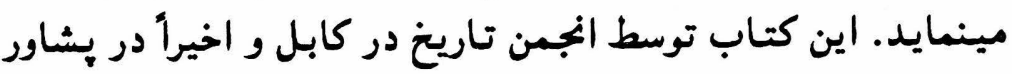

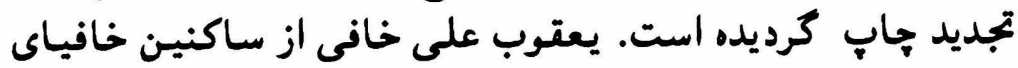

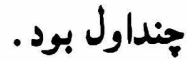

شيخ محمد رضا خزاسانى شخصيت شناخته شده در حلقه ماى ماى

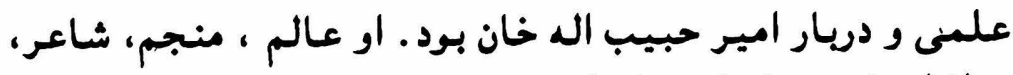

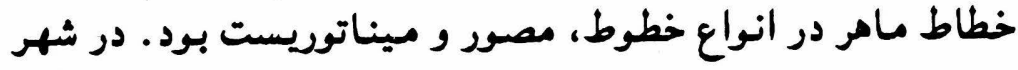

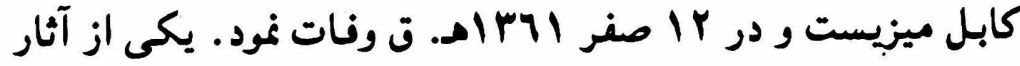

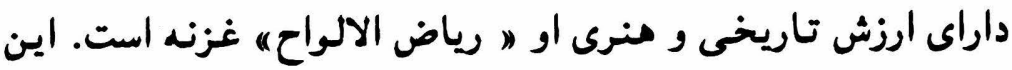

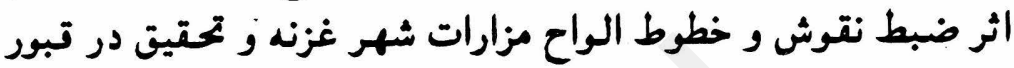

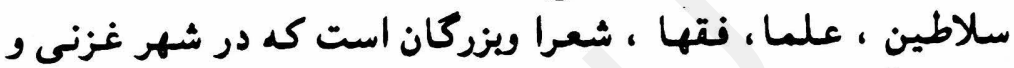

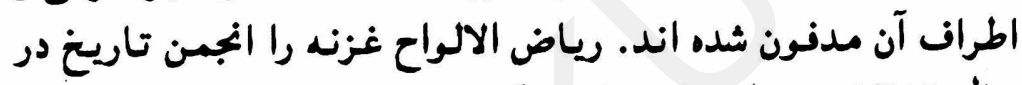

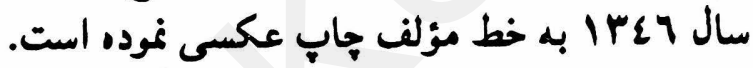

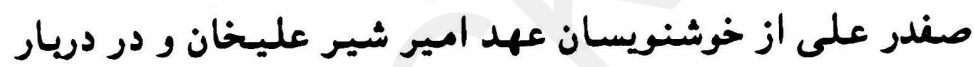

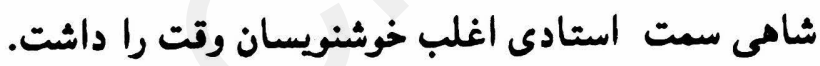

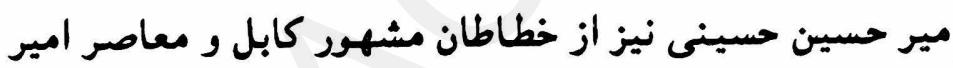

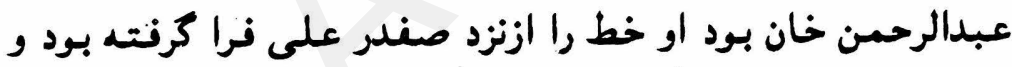

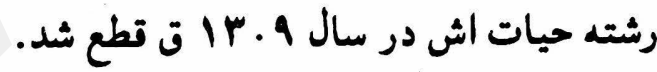

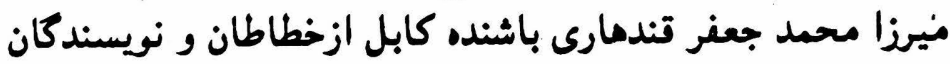

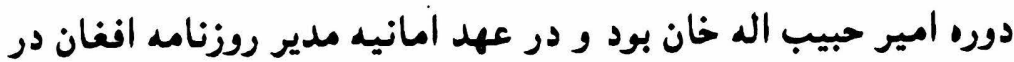

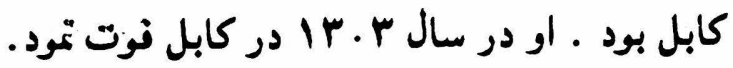

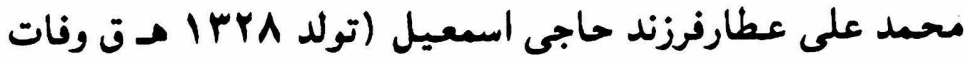

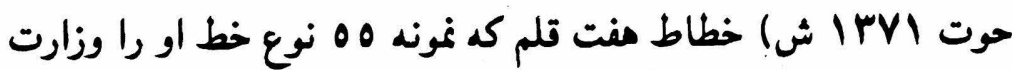

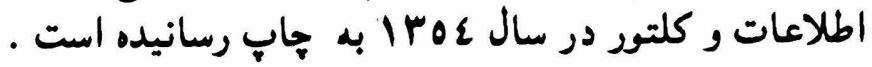

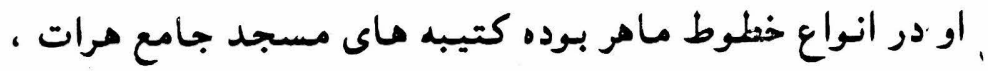

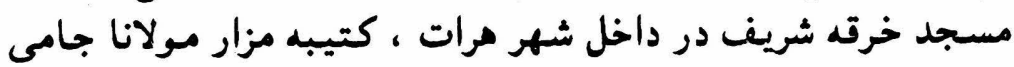


در خارج شهر، كتيبه مسجد جامع شيريور در كابل، كتيبه مسجد وتيد

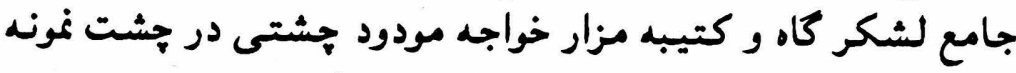

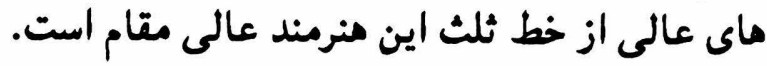

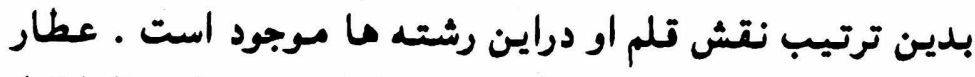

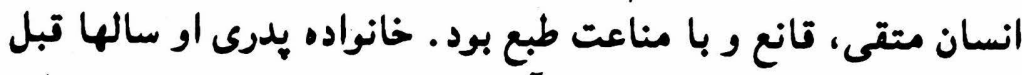

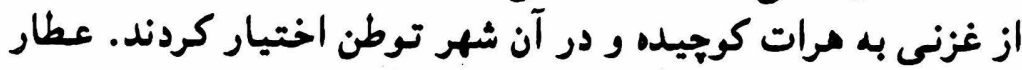

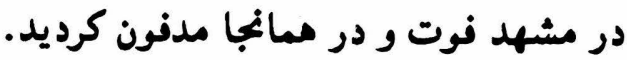

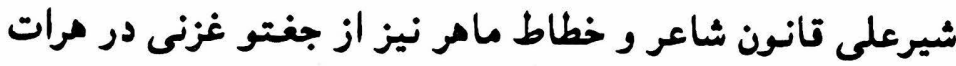

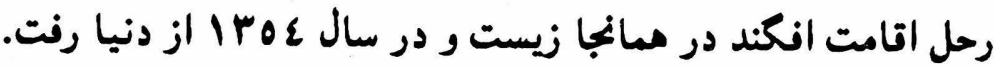

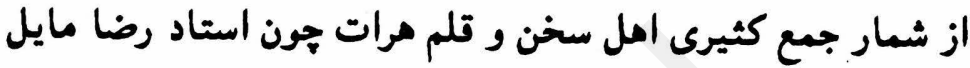

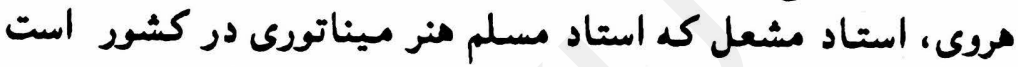

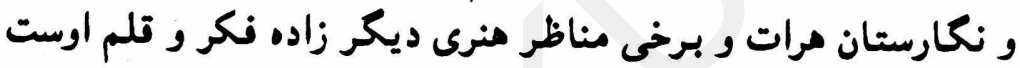

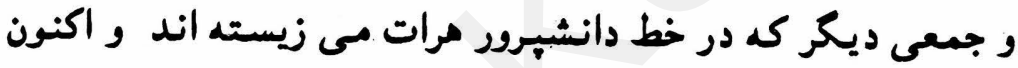

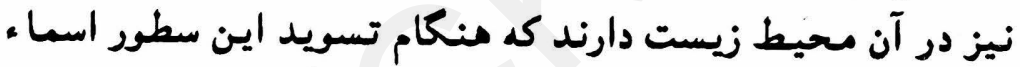
ايشان در حافظه نمانده است.

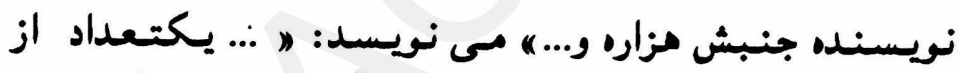

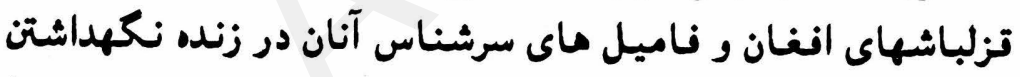

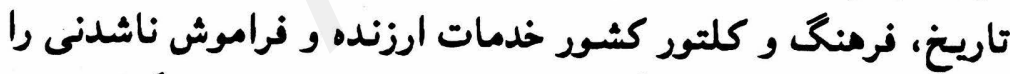

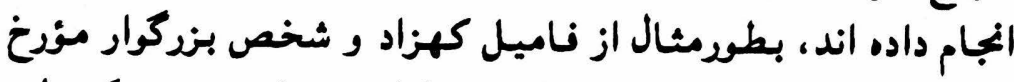

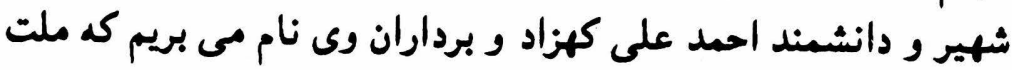

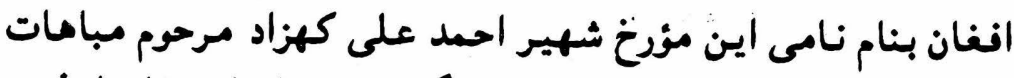

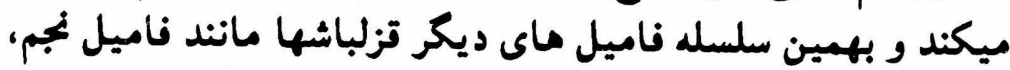

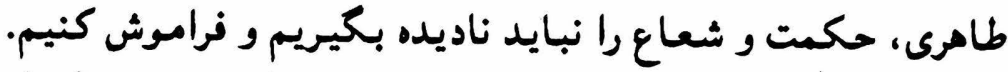

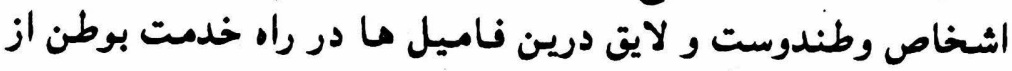
ميجكونه خدمتكذارى دريغ نكرده اند (ع ) .

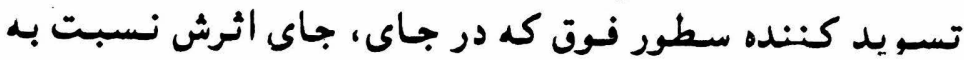




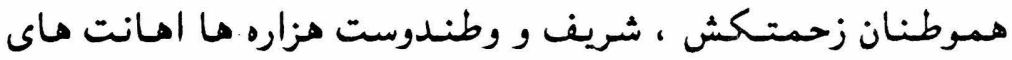

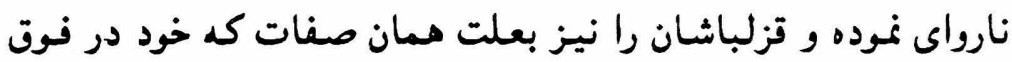

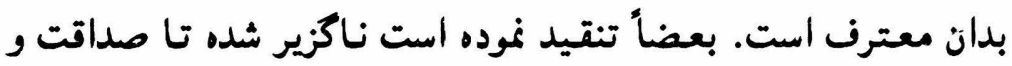
خدمات اين قوم را اعتراف نمايد.

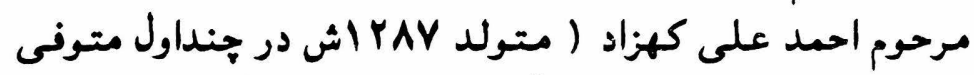

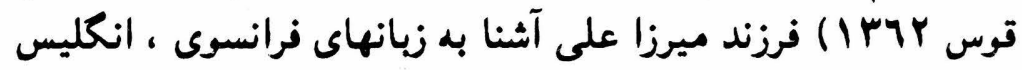

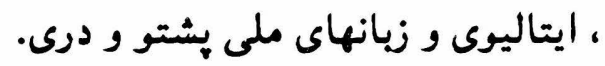

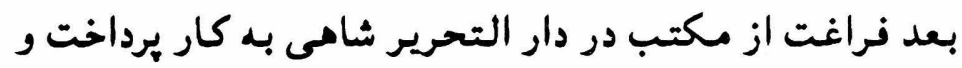

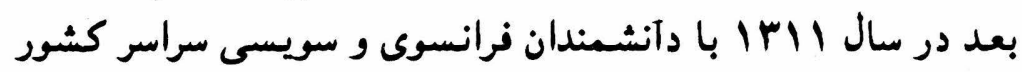

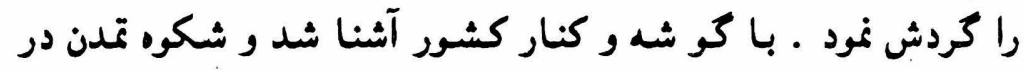

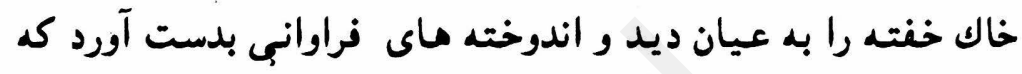

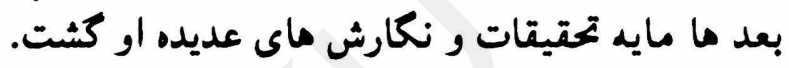

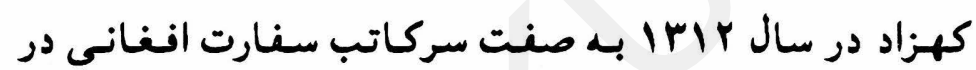

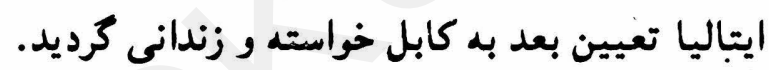

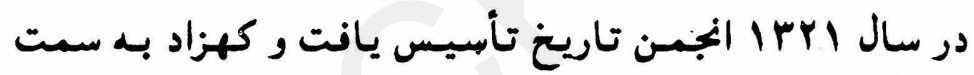

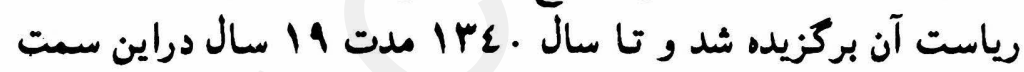

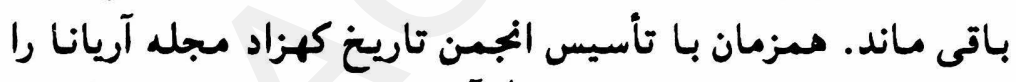

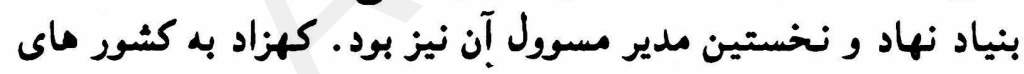

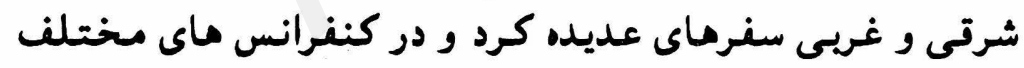

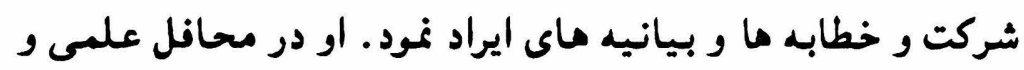

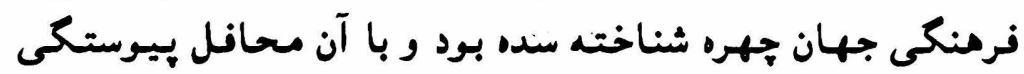
معنوى داشت.

كهزاد عضويت اكثر انجمن ماى علمى و فرمنكى جهان را داشت

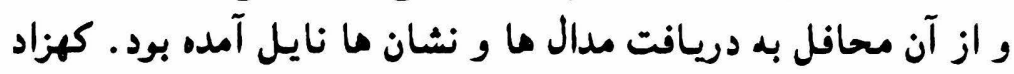

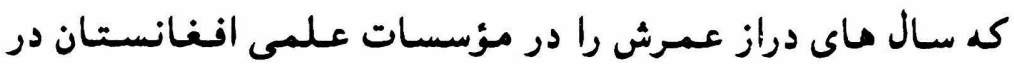

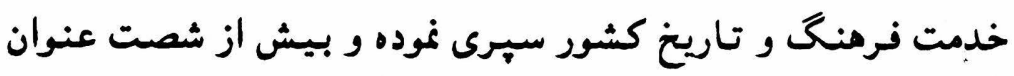




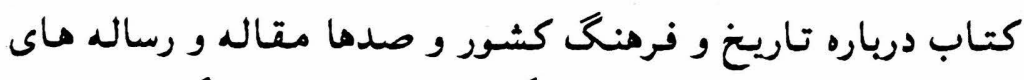

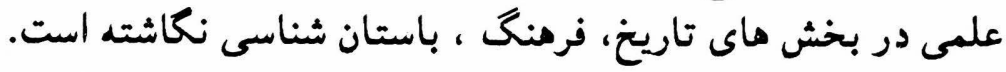

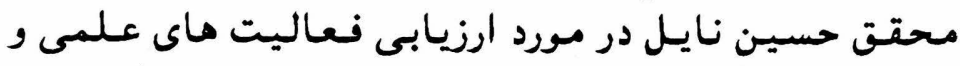

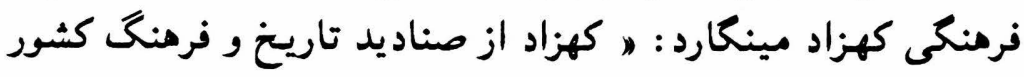

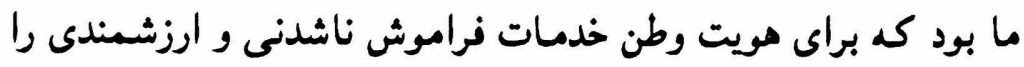

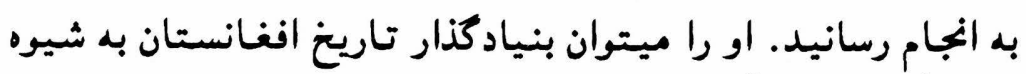

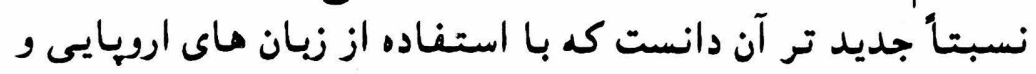

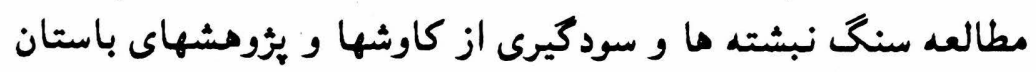

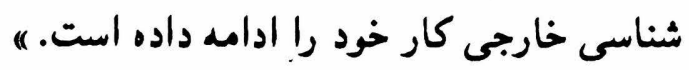

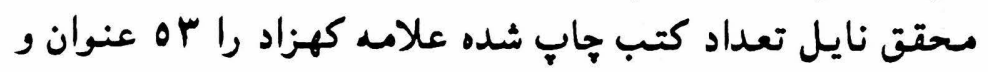

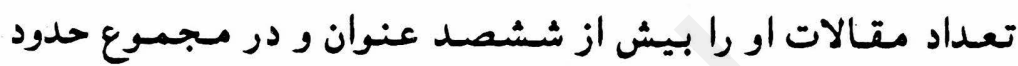

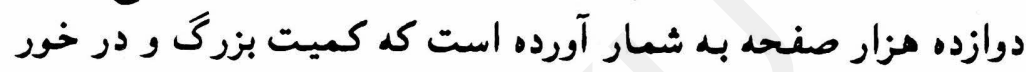
تامل است.

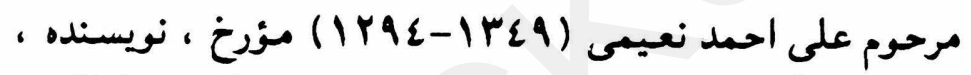

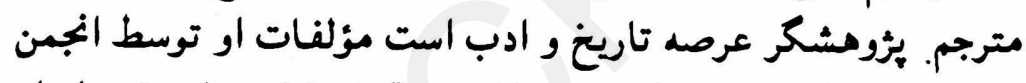

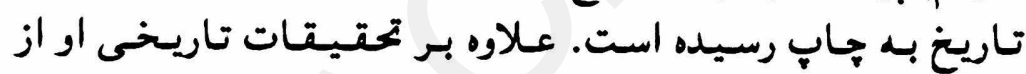

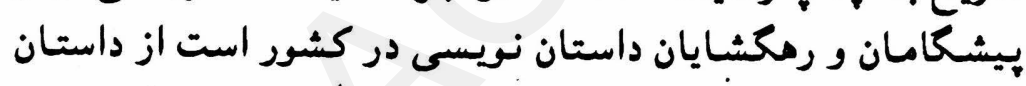

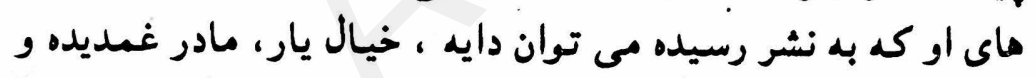

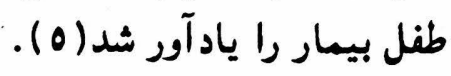

قزلباشان در مبارزه عليه استبداد :

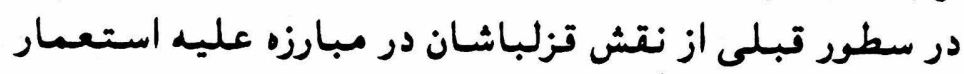

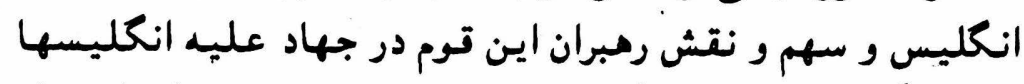

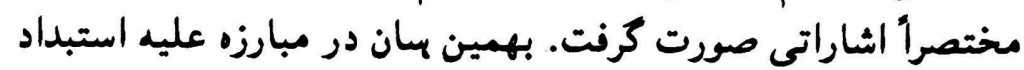

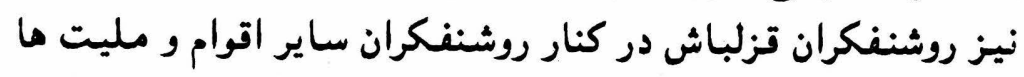

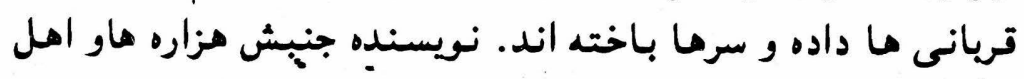




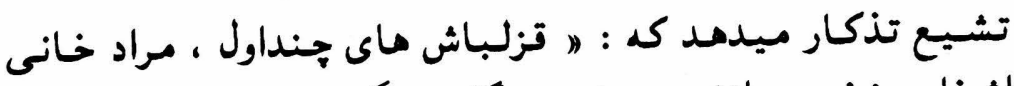

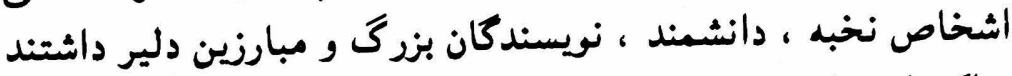

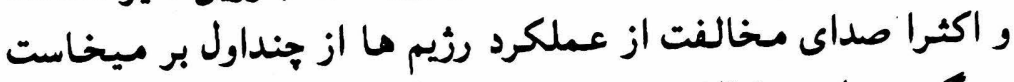

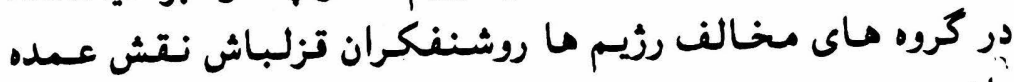

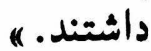

ناكنته هيداست كه مبارزه سياسى مستلزم داشتن فهم و فرمنح

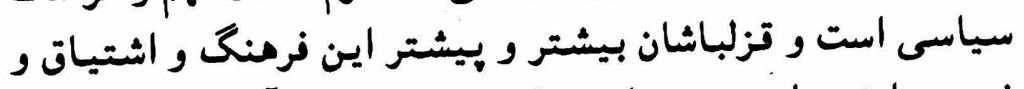

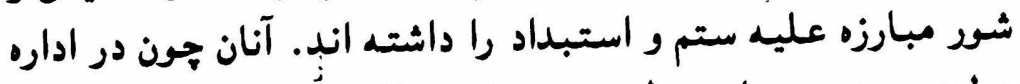

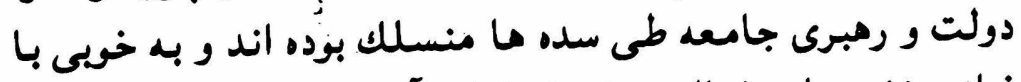

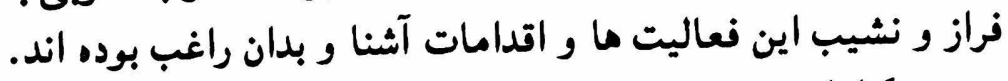

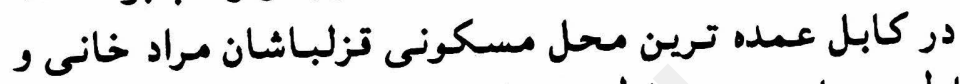

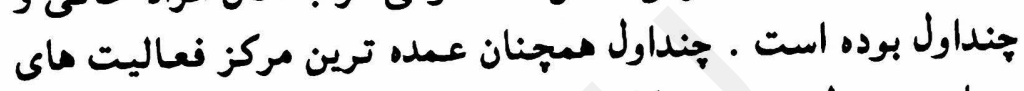

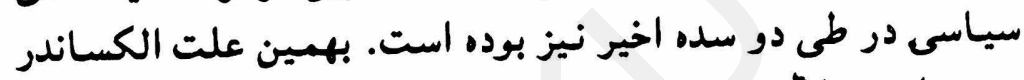

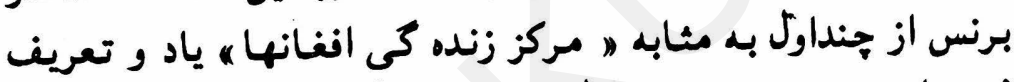

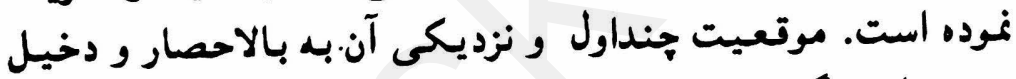

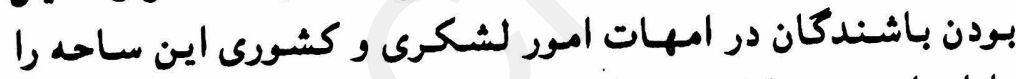

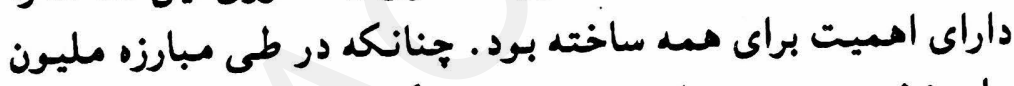

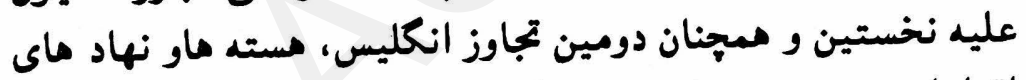

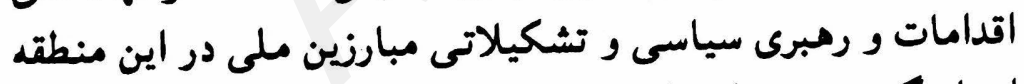

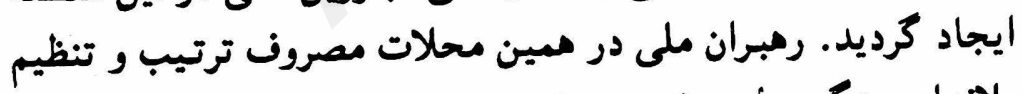
يلاتهاى جنكى عنيه دشمن بودند.

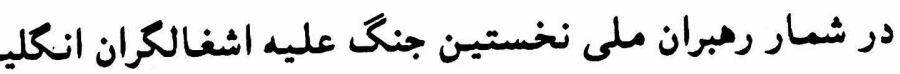

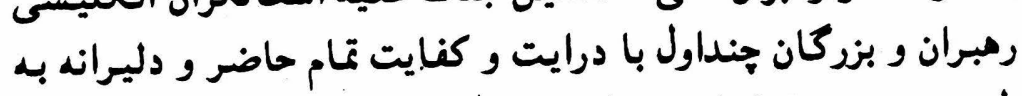

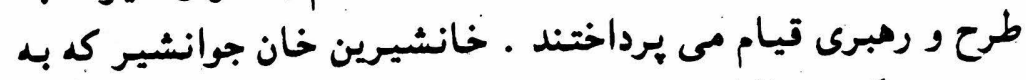

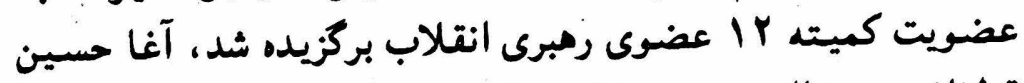

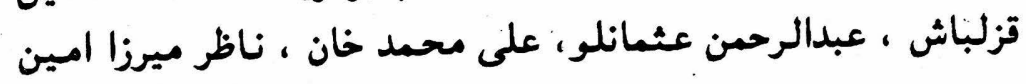


خان، محمد حسين عرض بيكى و محمود خان بيات ، ييوسته ممراه و مميار مبارزين ملى بوده اند.

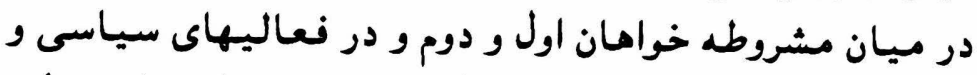

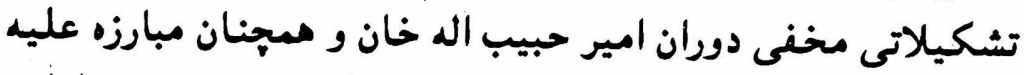

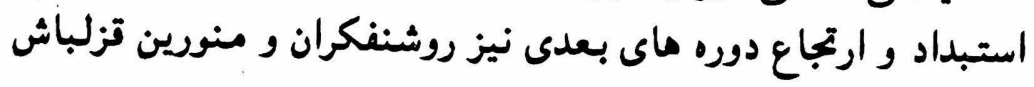
جاي شايسته داشته اند.

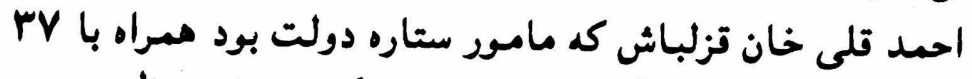

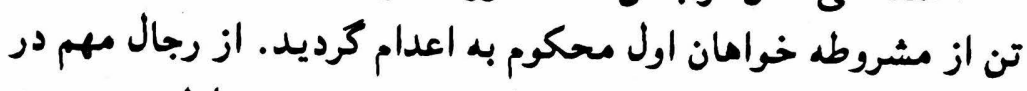

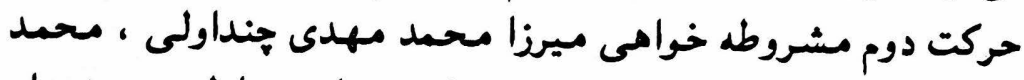

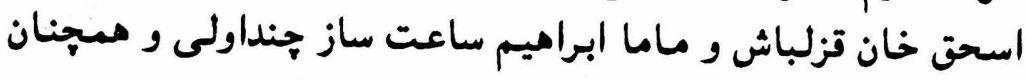

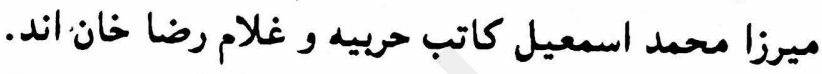

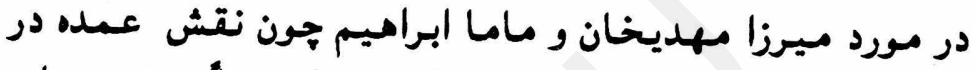

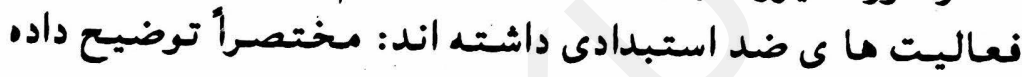

\section{ميرزا مهدى خان هنداولى:}

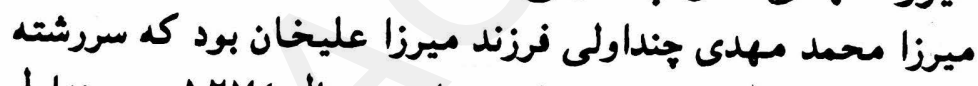

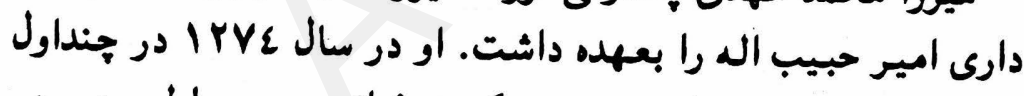

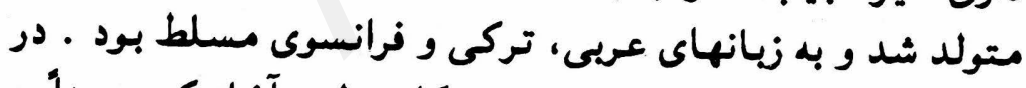

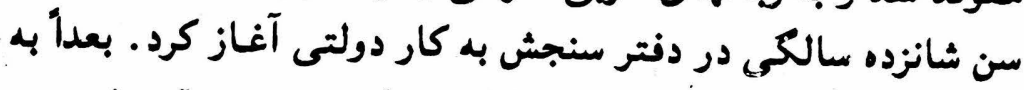

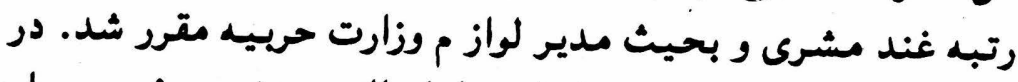

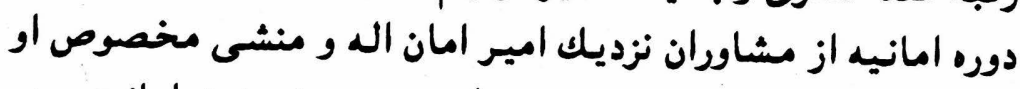

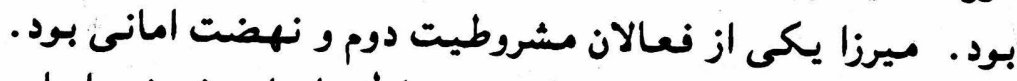

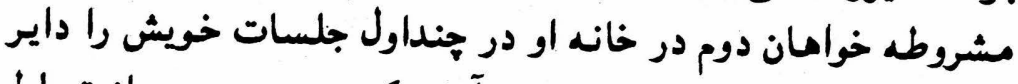

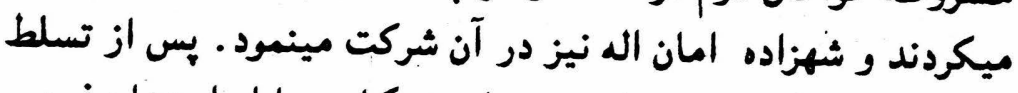

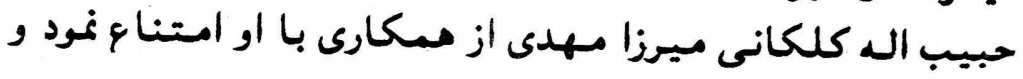


مخفيانه به سران قوم هزاره توصيه كرد تا از بيعت با حبيب اله امتناع نمايند.

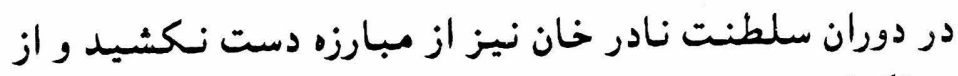

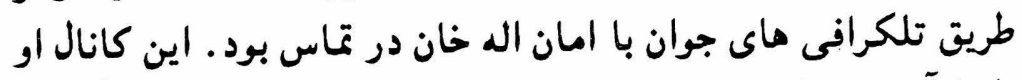

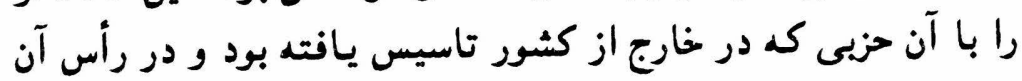

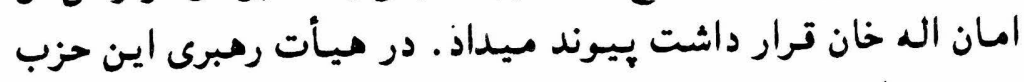

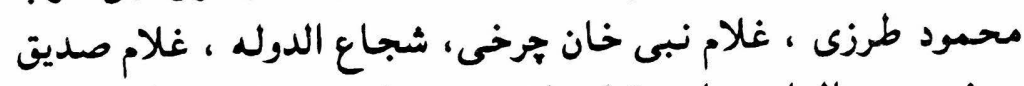

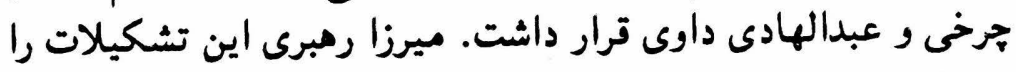

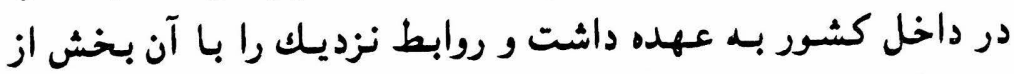

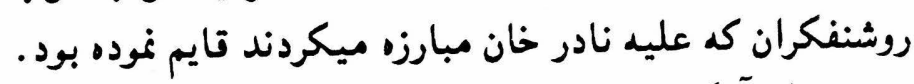

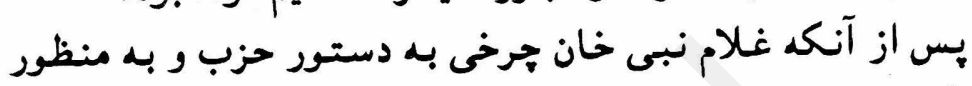

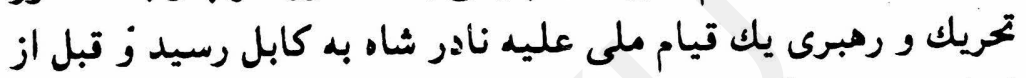

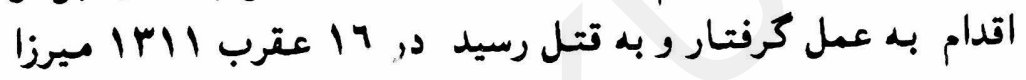

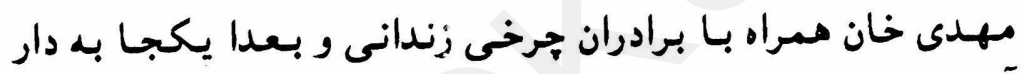

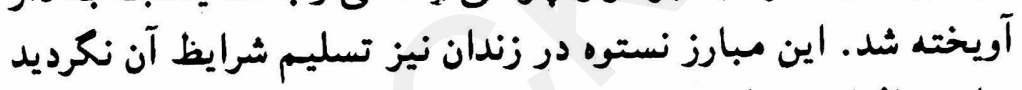

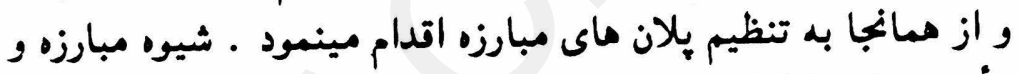

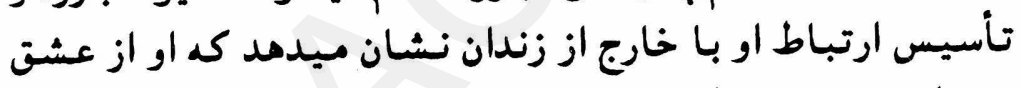

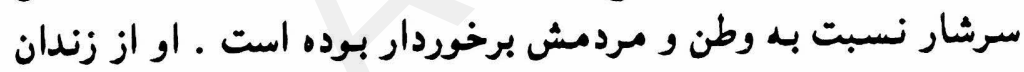

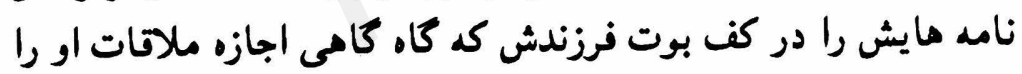

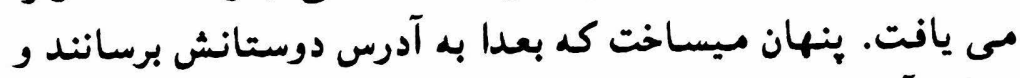

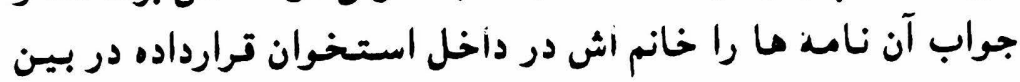

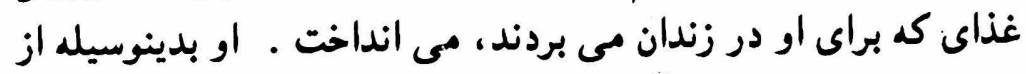

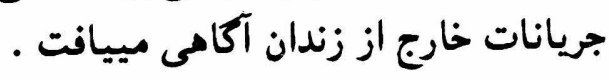

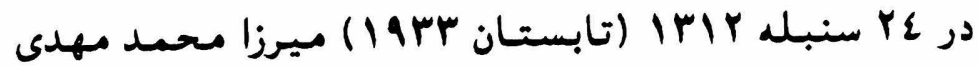

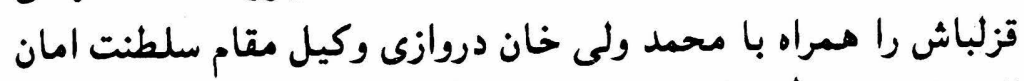

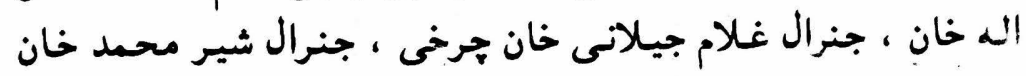




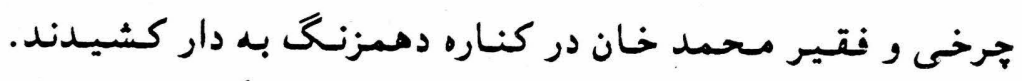

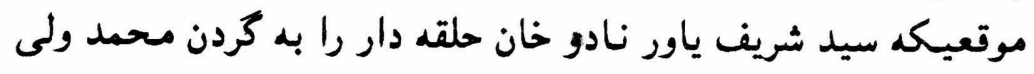

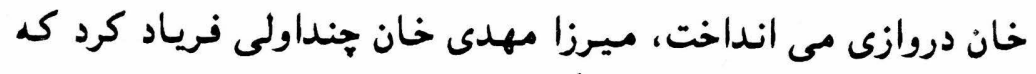

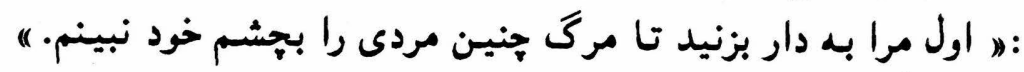

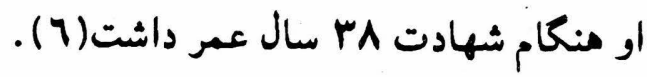

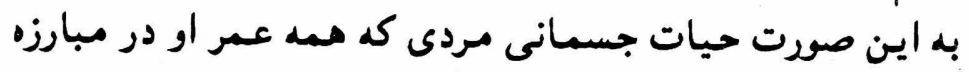

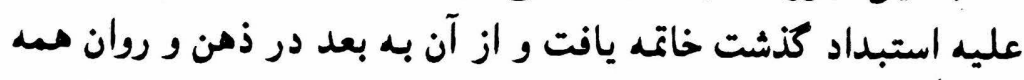

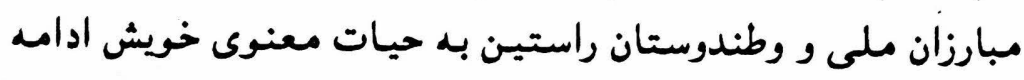

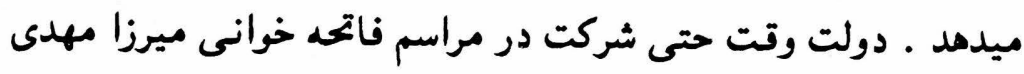

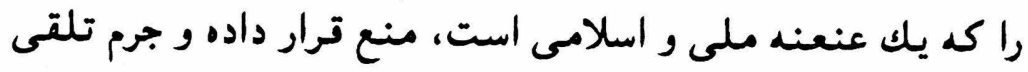

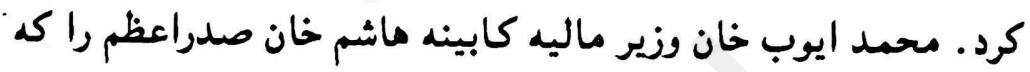
خويشاوند ميرزا مهدى بود ، بهمين جرم از كار بركنار كرد. ماليه كاينه ماند صدراعط

\section{ماما ابراهيم ساعت ساز:}

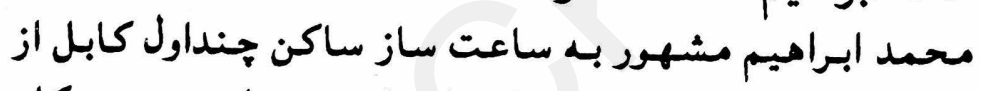

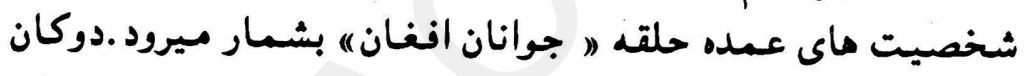

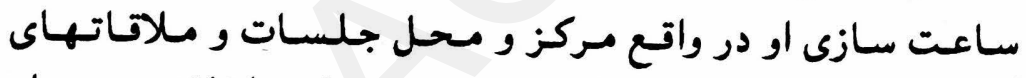

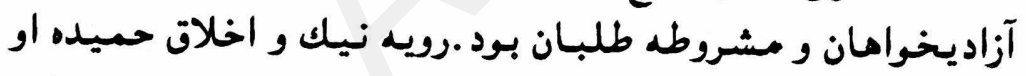

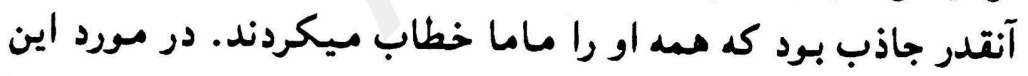

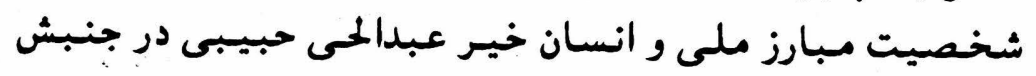

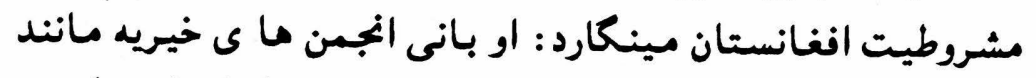

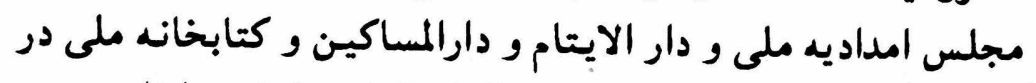

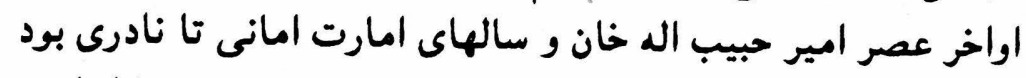

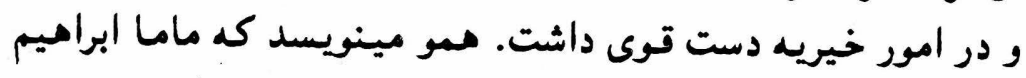

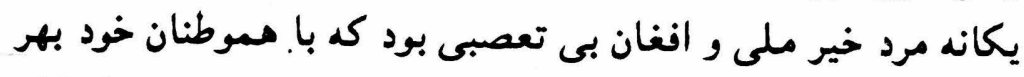

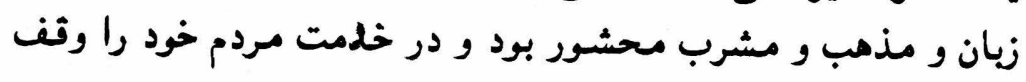


كرده بود. او مر جه كه داشت به مستحقان و مستمندان و يتيمان

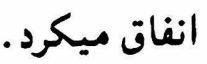

شخصيت نيك و جذاب محمد ابراميم جوان در ايام فرار از وطن حئن

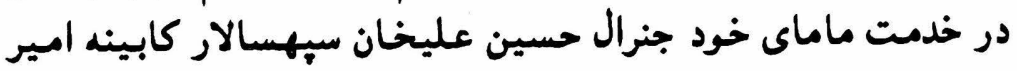

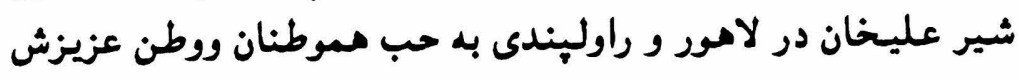

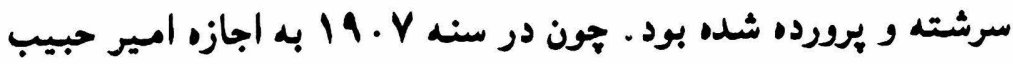

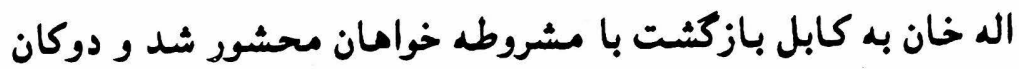

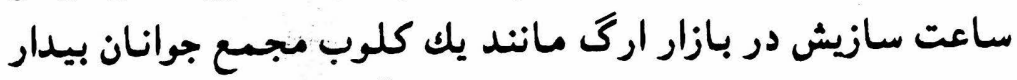

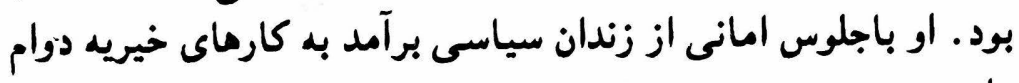

داد.

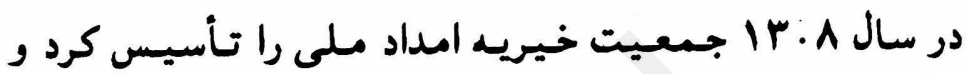

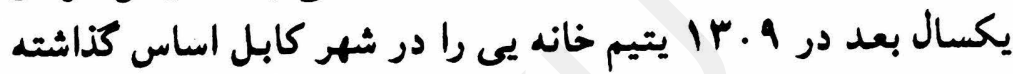

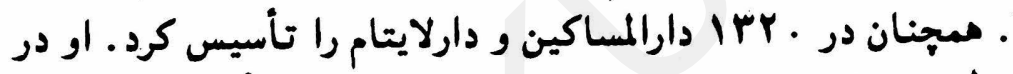

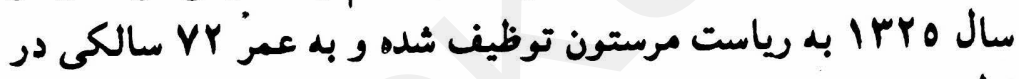

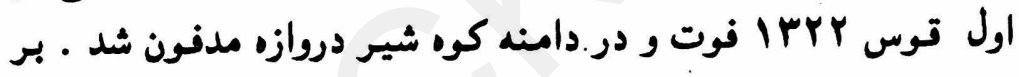

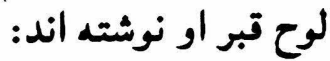

كذشت آن حاجى باكيزه طينت

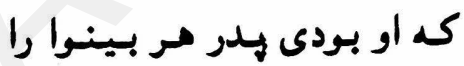

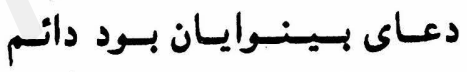

نصيب اش خير كن يروردكارا

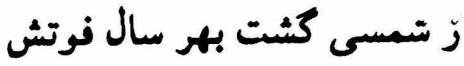

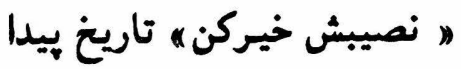

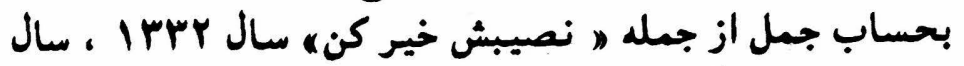

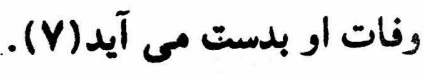

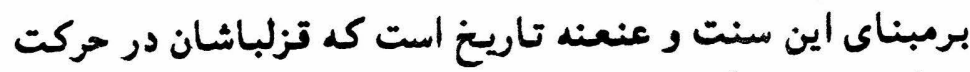
هاى فكرى و روشنكرى و توسعه و تعميق دموكراسئ و آزادى ملى ونى

$1 \ldots$ 
هيوسته در كنار ساير مموطنان خويش كوشا و ساعى بوده اند. اينان

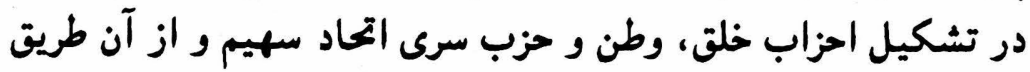

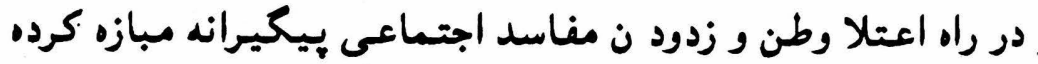

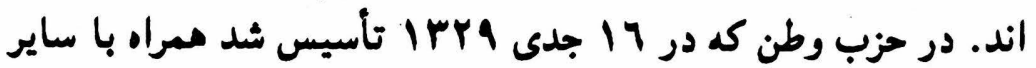

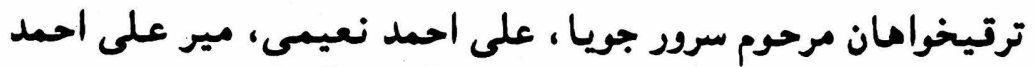

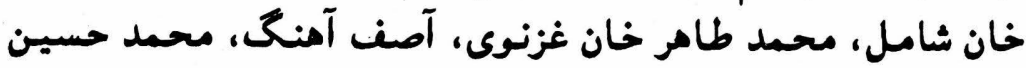
نهضت، فتح محمد ميرزاد و سايرين قرار داشتيند.

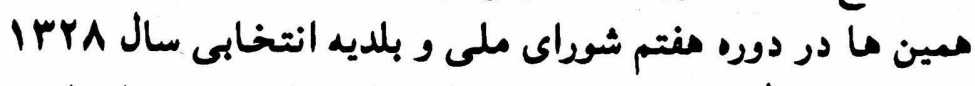

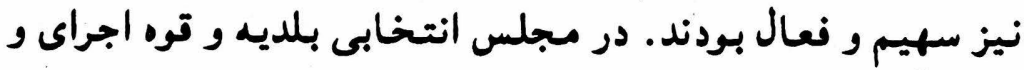

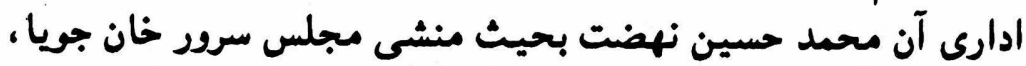

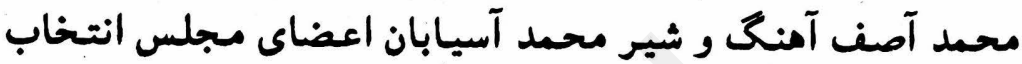
كرديدند.

در حلقه مركزى "•حزب سرى اتحاد ، كه براى استترار جمهوريت

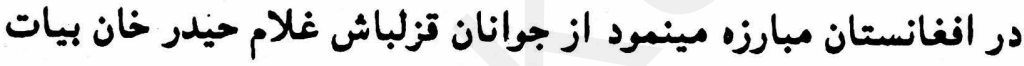

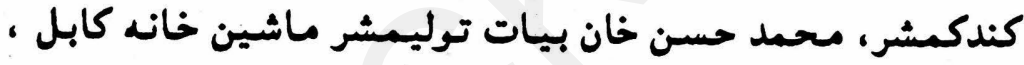

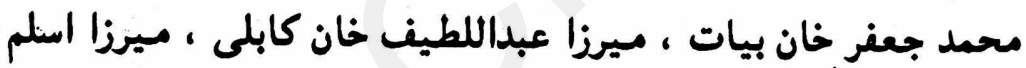

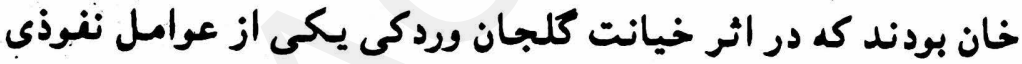

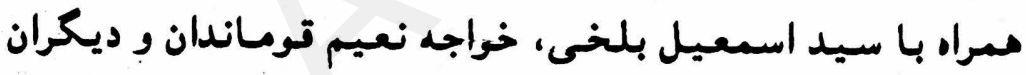

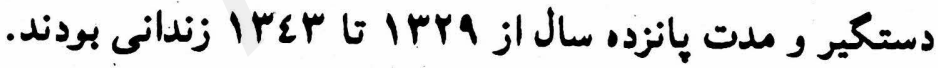

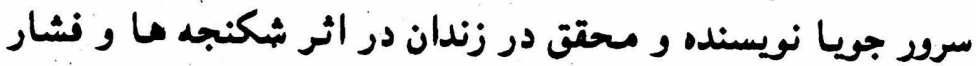

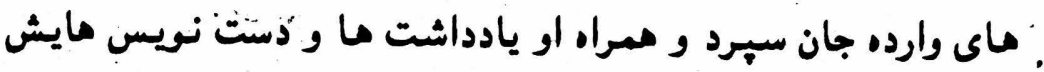
نيز مغقود كرديد.

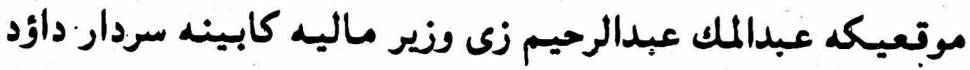

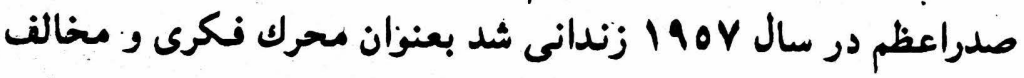

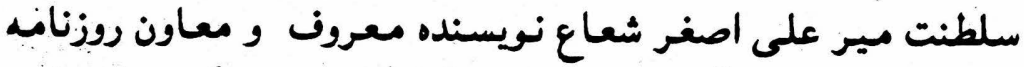

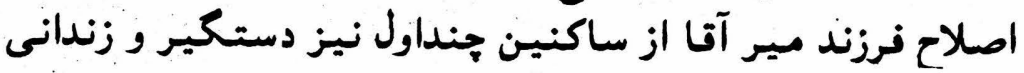


شعاع در زندان آنقدر شكنجه ديد كه بزودى جان سيرد و جسـد

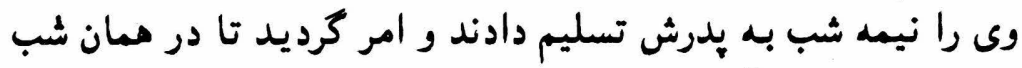

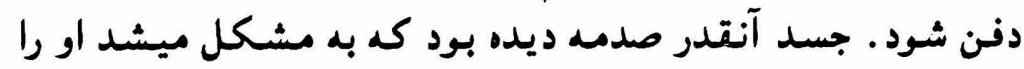

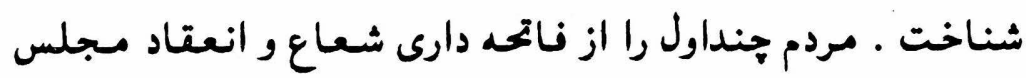

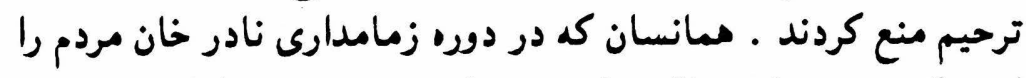

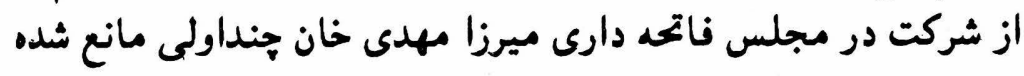
بودند.

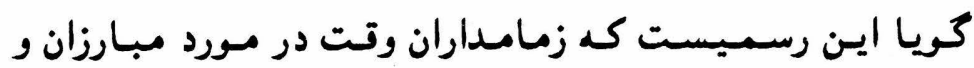

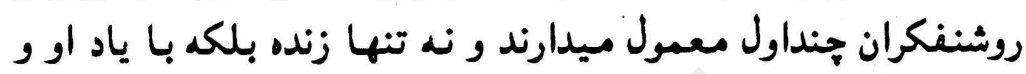

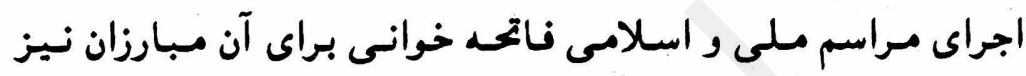

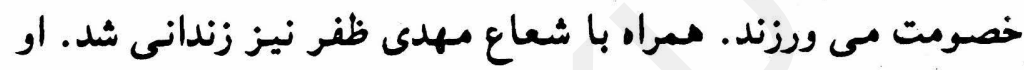
نطاق راديو كابل بيدو.

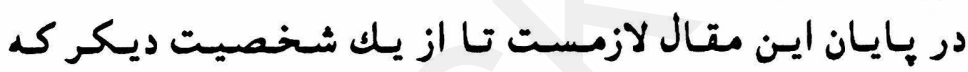

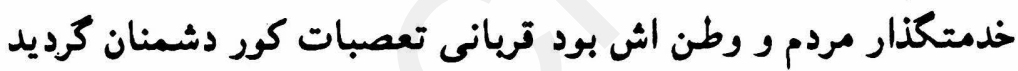

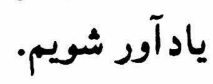

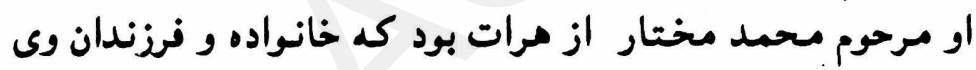

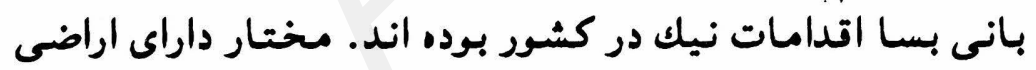

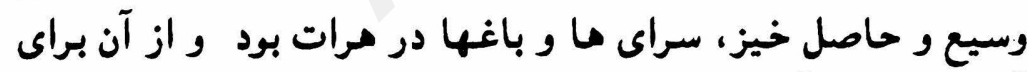

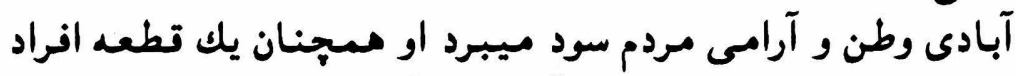

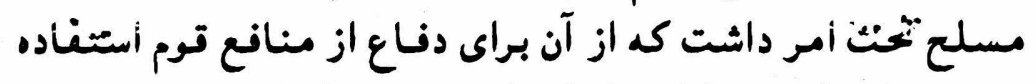

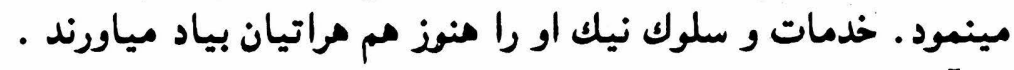

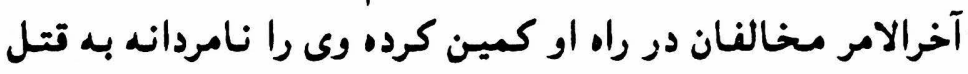

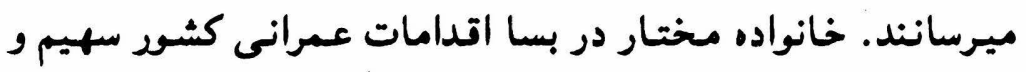

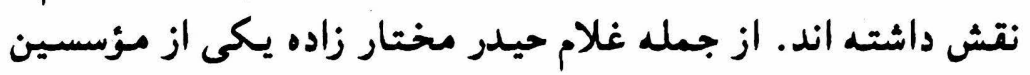

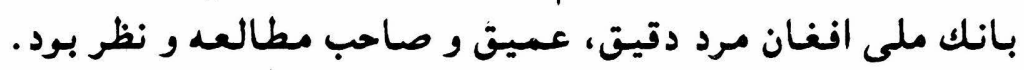




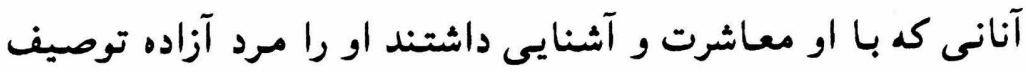

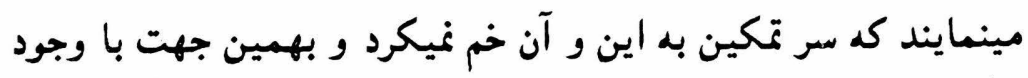

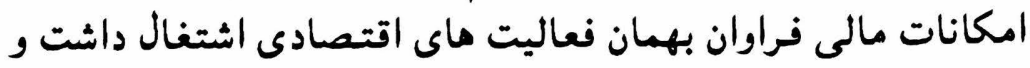
از دربار و سرداران دورى مى جست.

$$
\text { شعرا و ادبا: }
$$

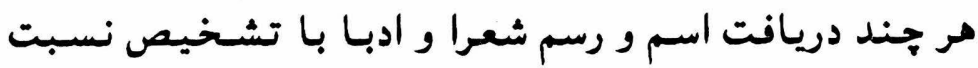

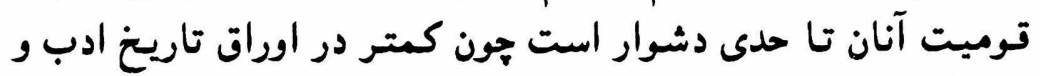

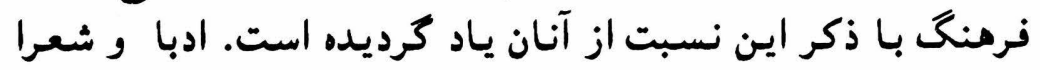

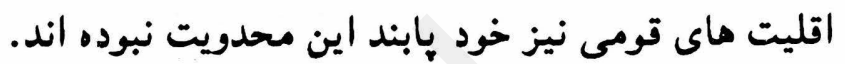

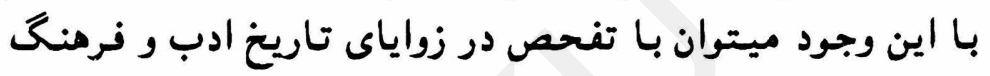

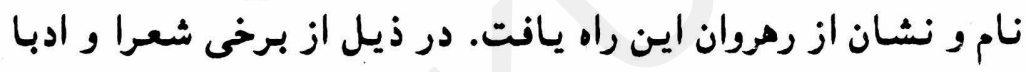
قرون ماضيه مختصر ذكرى بعمل مهرو ميايد:

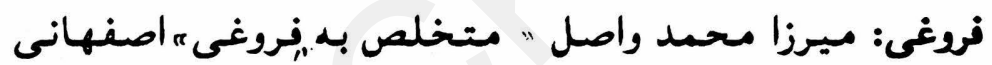

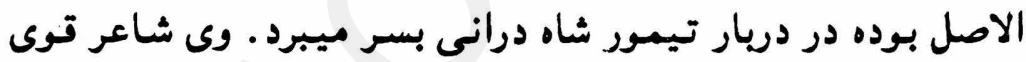

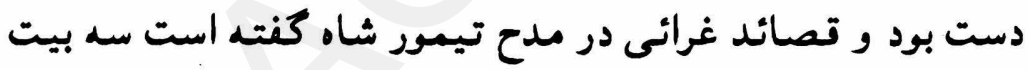

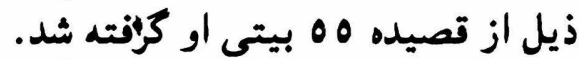

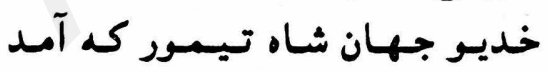

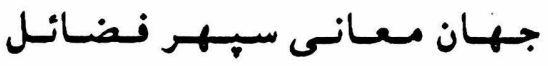

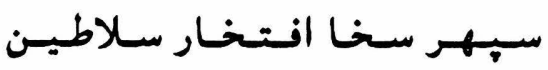

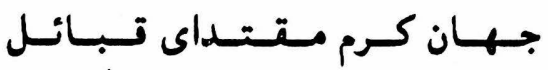

كمين جاكرش صد جو دار الأ مرمز

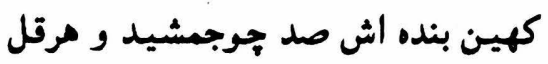

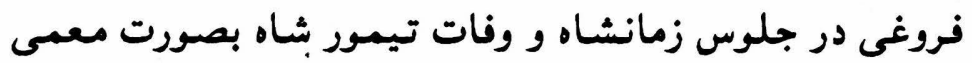

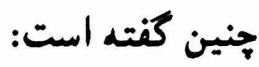


دونتش جه دلحواه ، جه جانكاه نشست

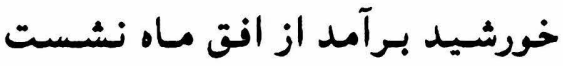

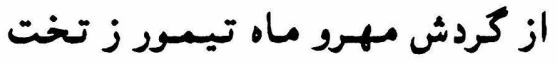

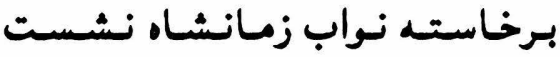

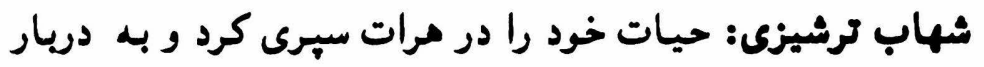

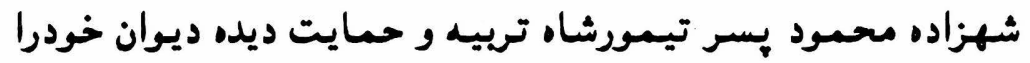

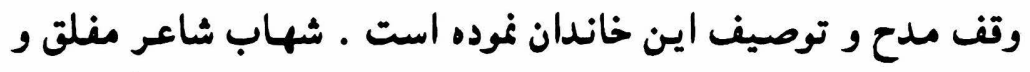

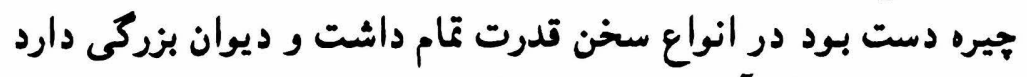

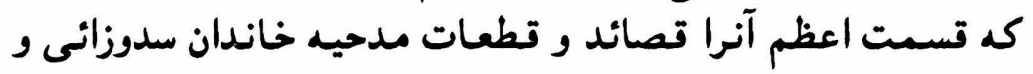

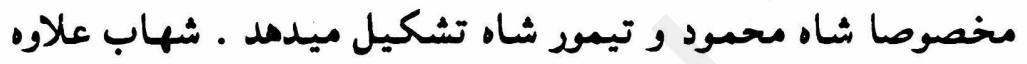

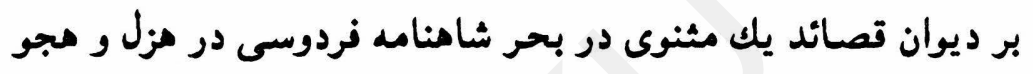

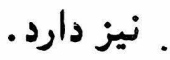

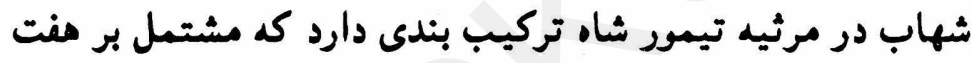

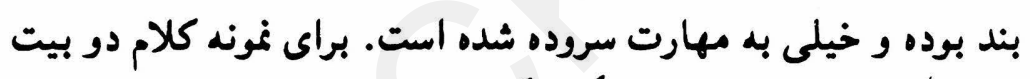

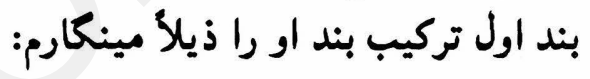

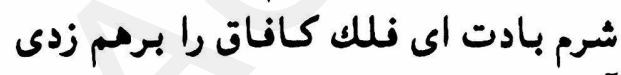

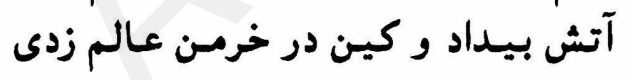

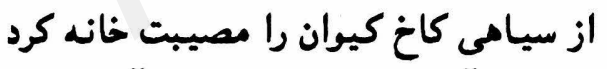

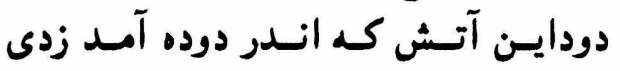

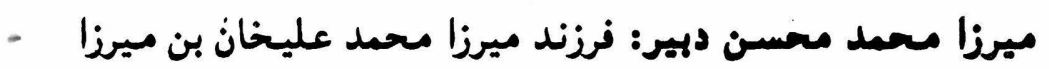

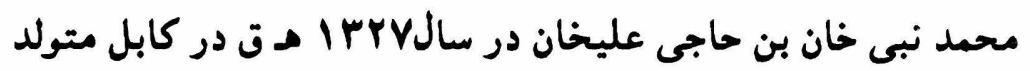

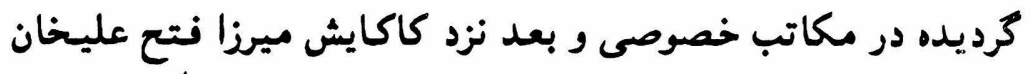

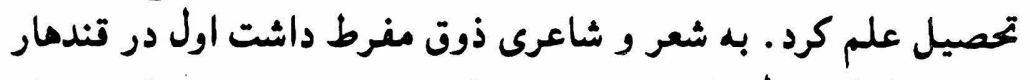

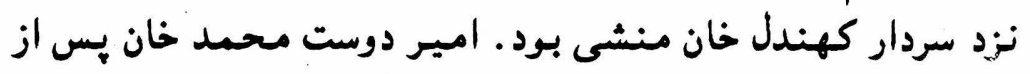

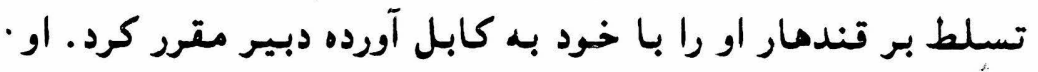

$1 \cdot \varepsilon$ 


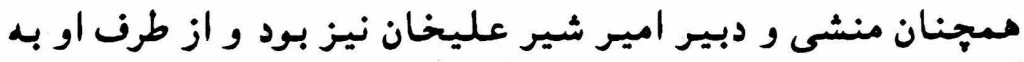

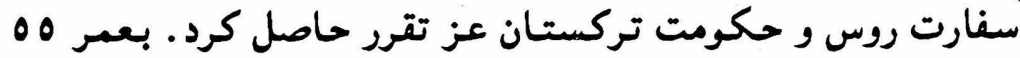

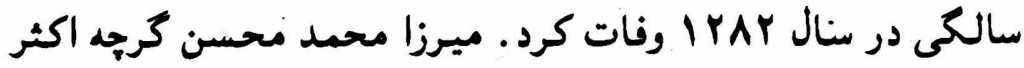

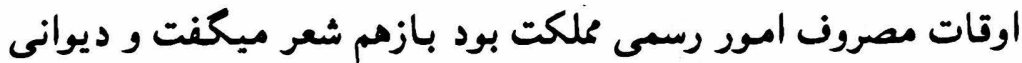

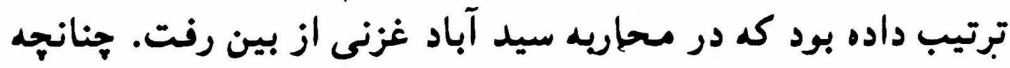
درين مورد كفته است.

$$
\begin{aligned}
& \text { اكر از شه ما زر و تاج رفت } \\
& \text { كتابى زما مم بد تاراج رفت مات ونت رفت }
\end{aligned}
$$

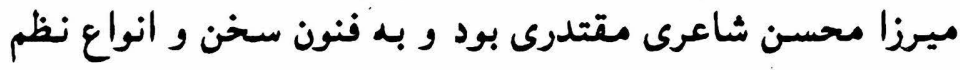

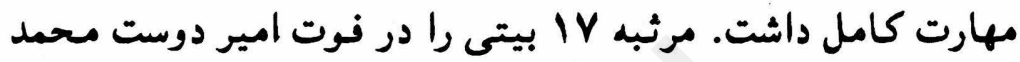
خان سروده كد جند بيت آن درج شد ماثد

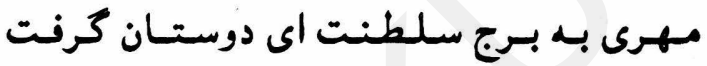

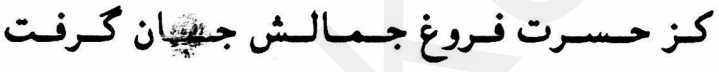

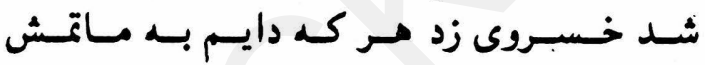

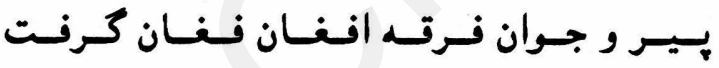

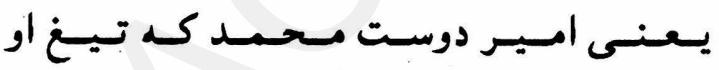

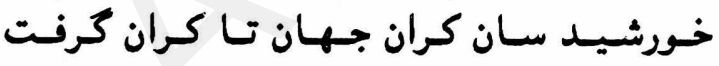

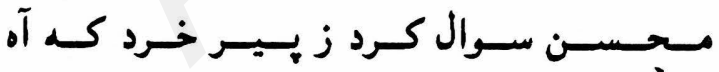

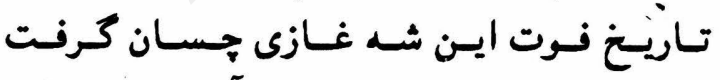

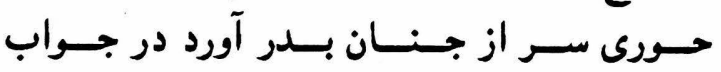

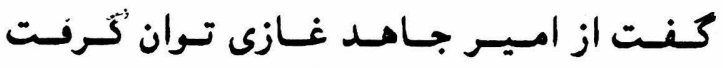

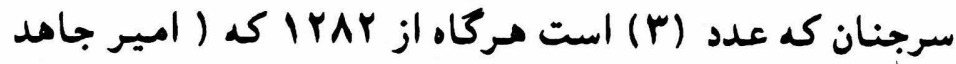

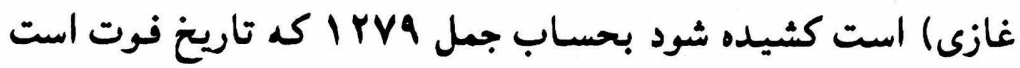
باقى ميماند.

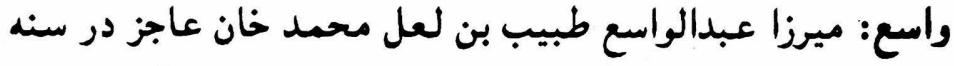

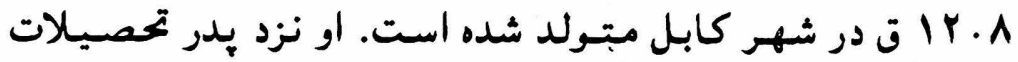


ابتدائى را فراكرفته در فن طبابت مهارت به سزا حاصل و مانند بدر

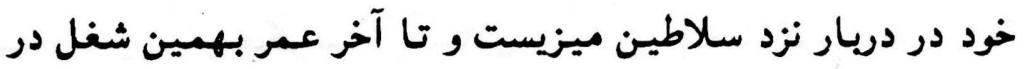

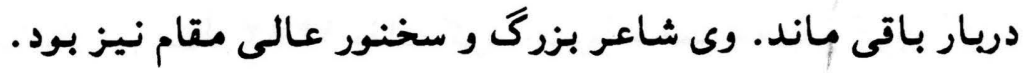

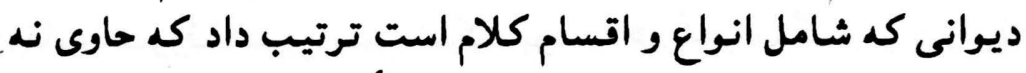

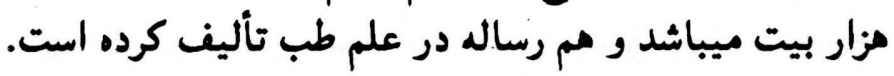

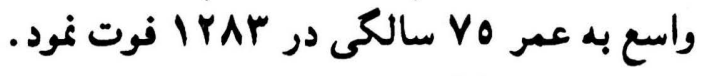

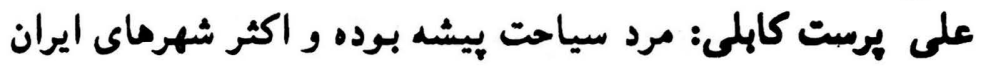

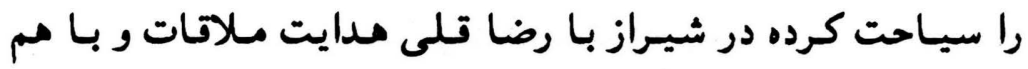

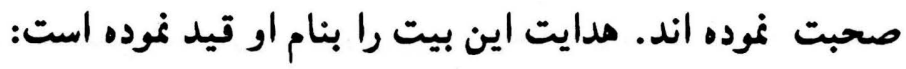
افتادن و برخاستن باده يرستان در مذهب رندان خرابات نماز است باد برنان

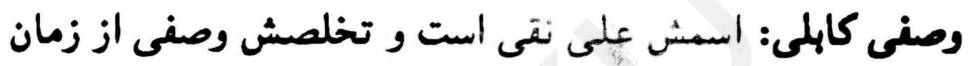

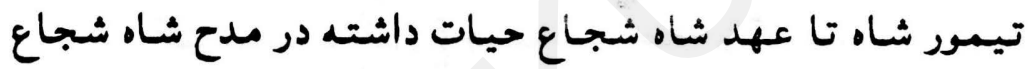

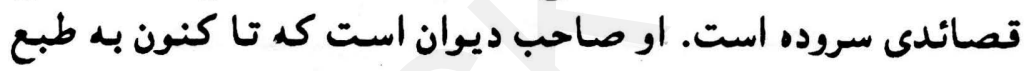

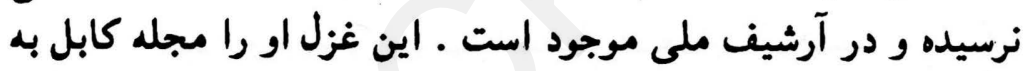
جاب رسانيده كه اقتباس ميكردد :

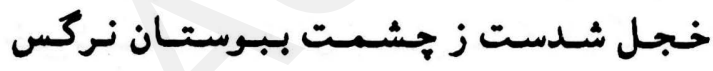

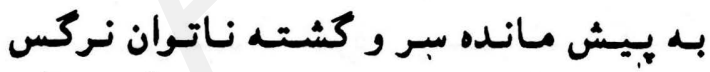

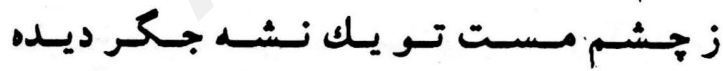

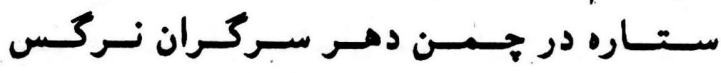

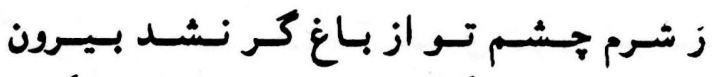

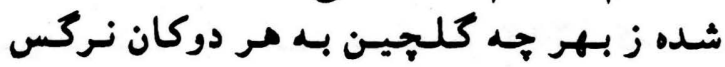

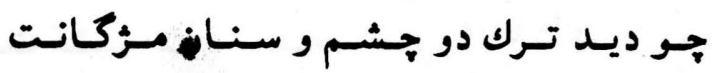

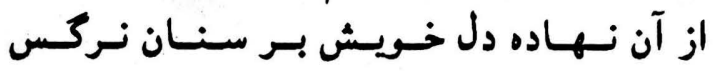

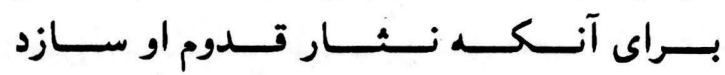

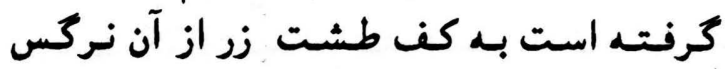




$$
\begin{aligned}
& \text { مـكر بـه بـاى تـو مـاليـد جشـــم خـود كز قـدر }
\end{aligned}
$$

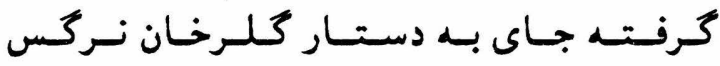

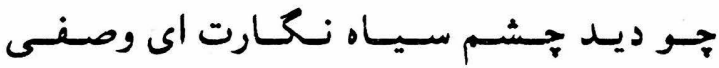

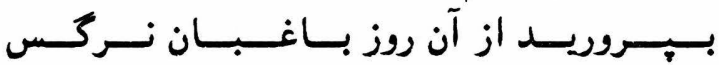

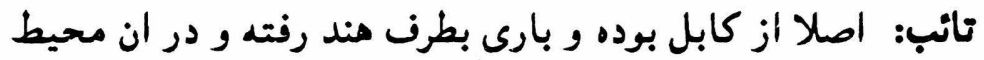

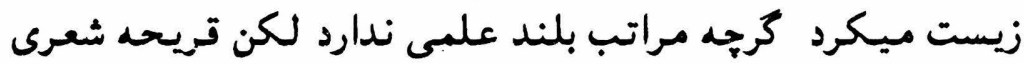

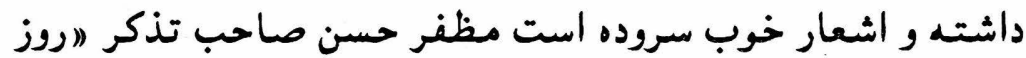

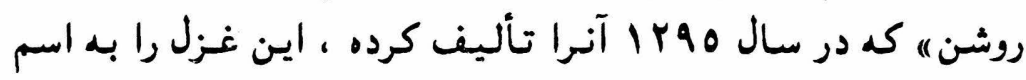
تائب قيد نموده است:

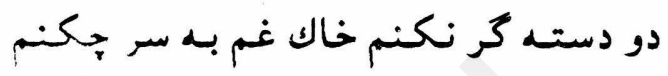

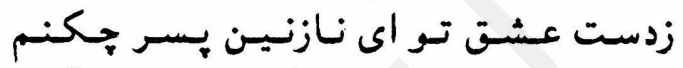

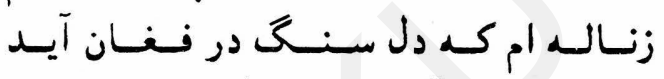

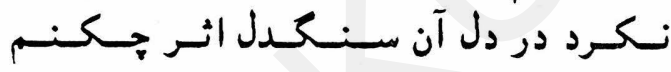

خراب خـانه مـن كرد عـشـت خـانسه خراب

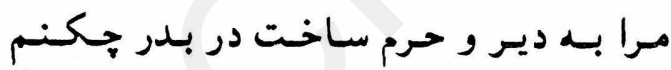

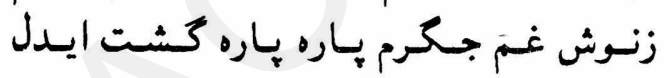

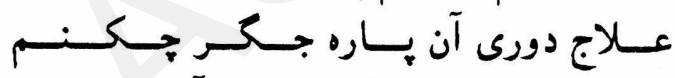

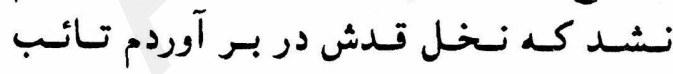

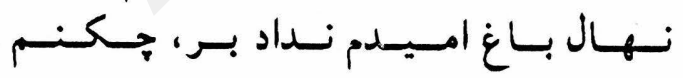

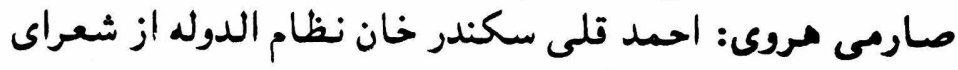

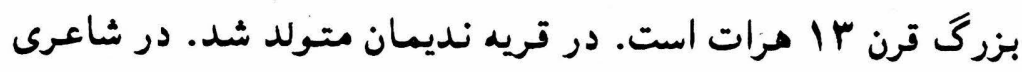

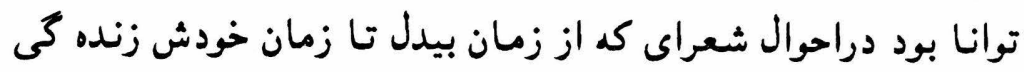

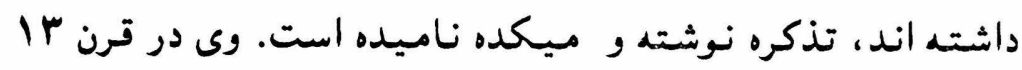
فوت شده و در روضه احمد جام دفن شده است.

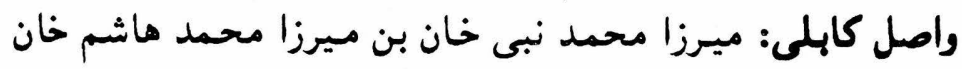

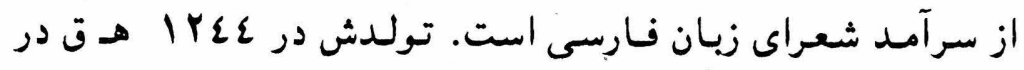


كابل واقع شده ، تعليمات مقدماتى را در مراد خانى كابل از نزد

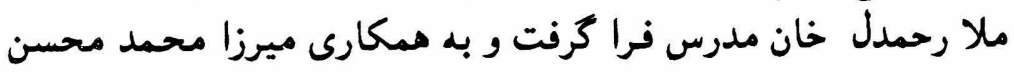

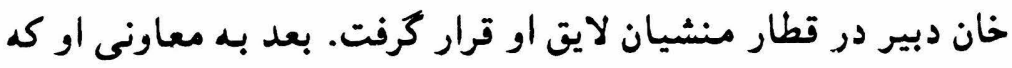

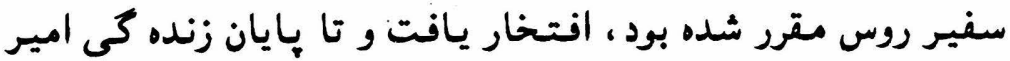

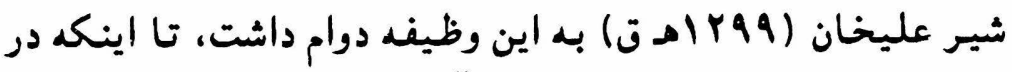

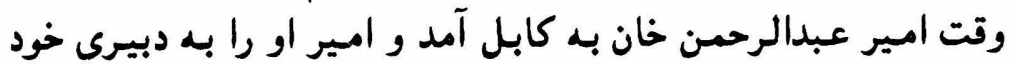

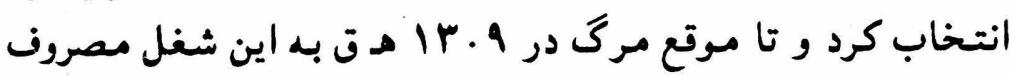

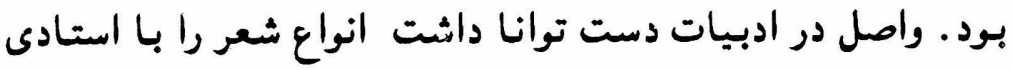

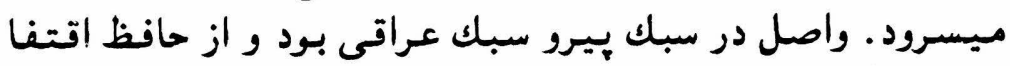

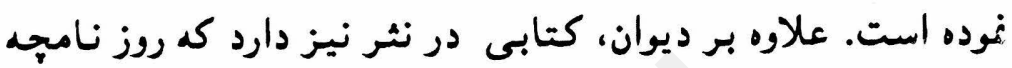
حيات امير شير عليخان را تشكيل مئل ميدهد.

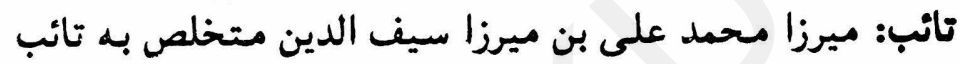

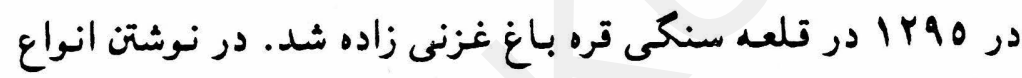

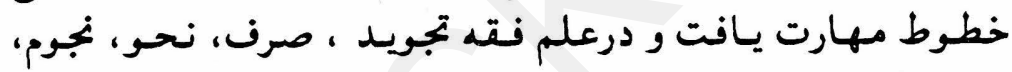

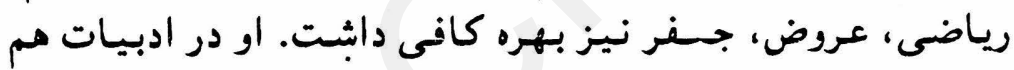

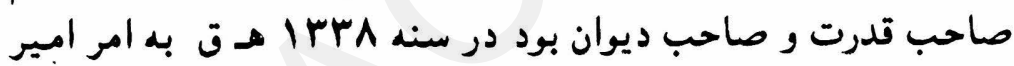
حبيب اله به جرم مشروطه طلبى مقتول مران ورديد.

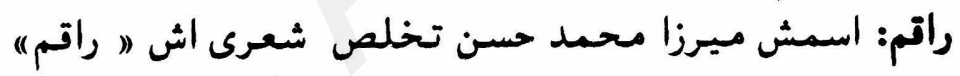

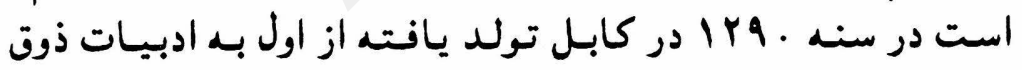

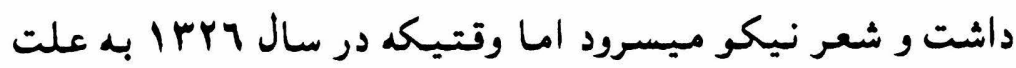

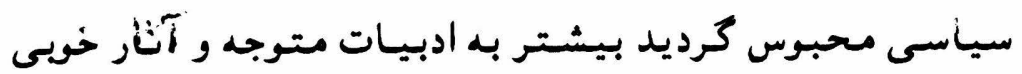

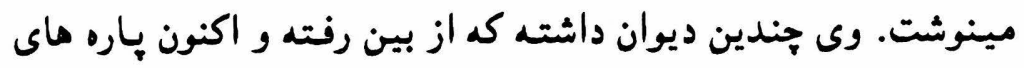
از غزليات بجا مانده است.

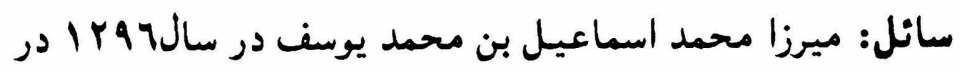

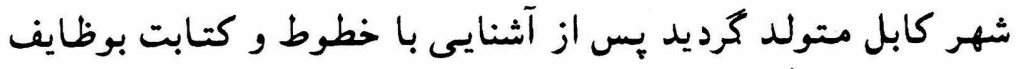

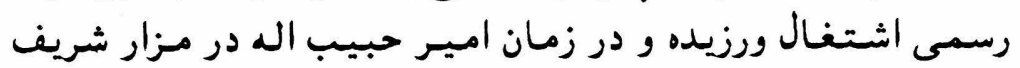




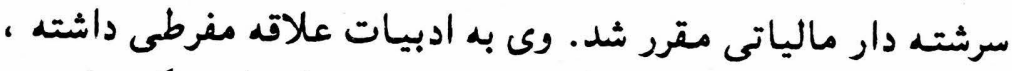

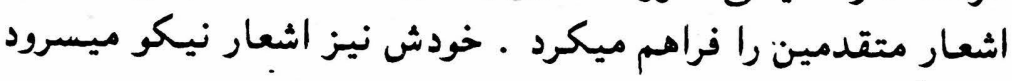

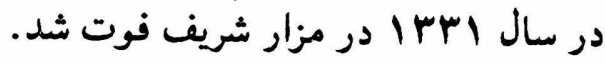

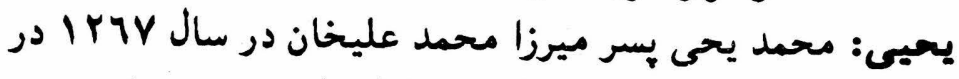

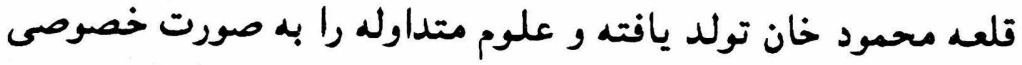

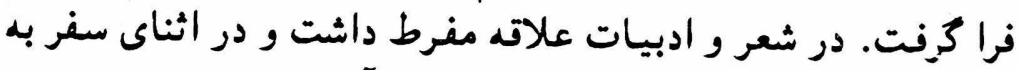

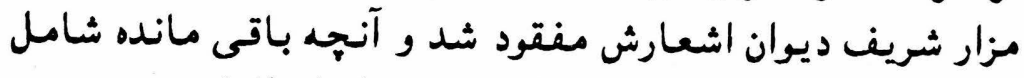


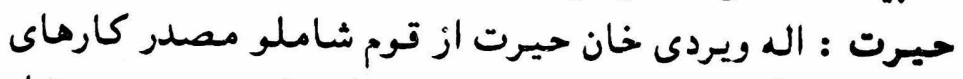

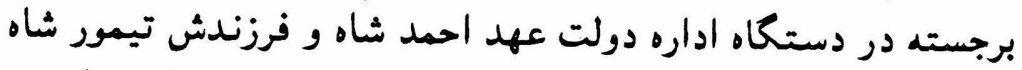

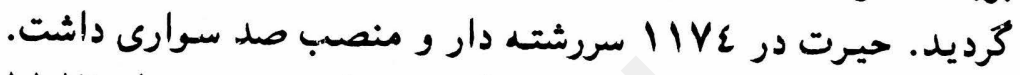

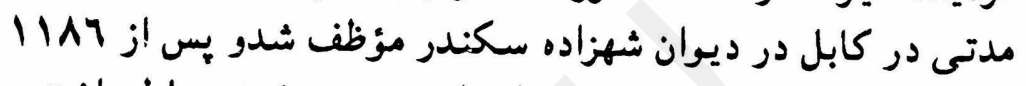

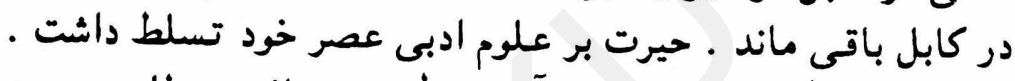

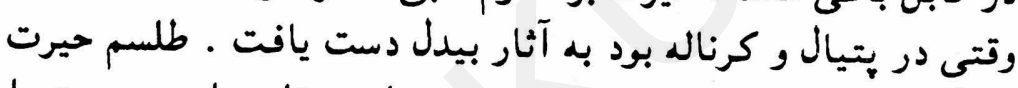

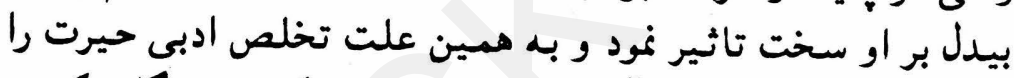

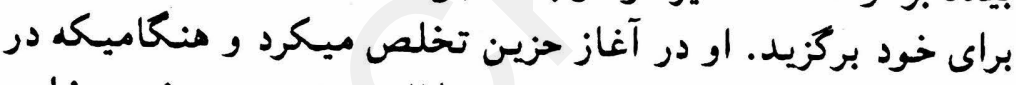

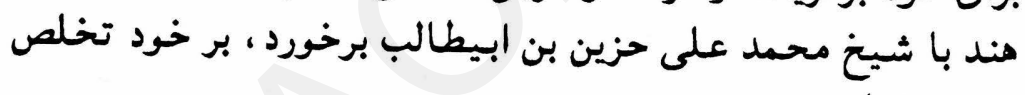
محزون نهاد.

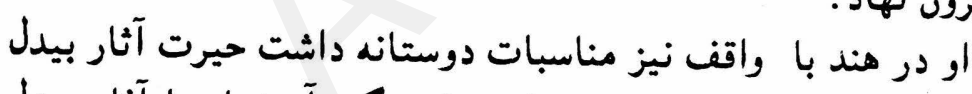

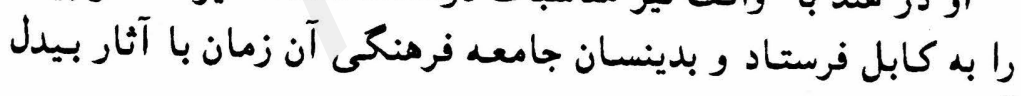
آشنائى يافت.

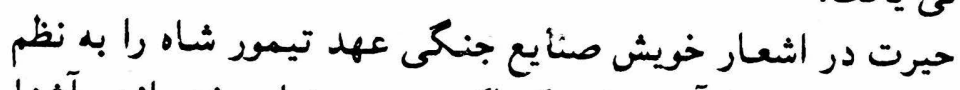

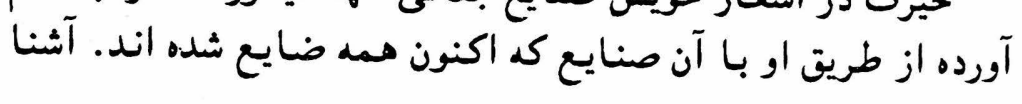

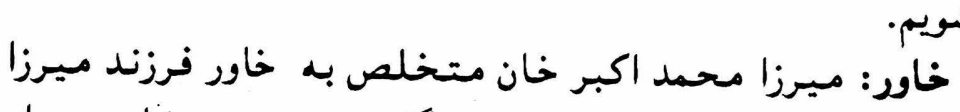

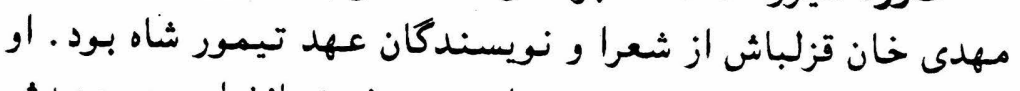

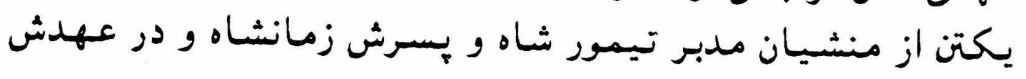


مشهور در دريار از اعتبار فراوان برخوردار بود.

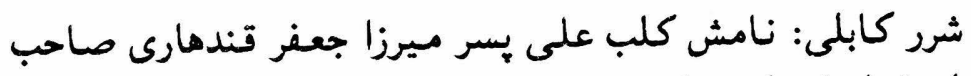

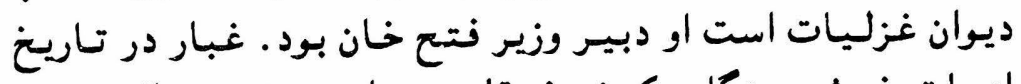

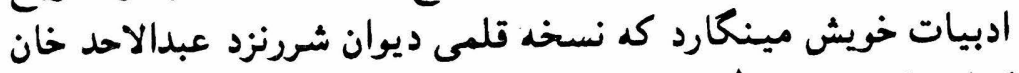

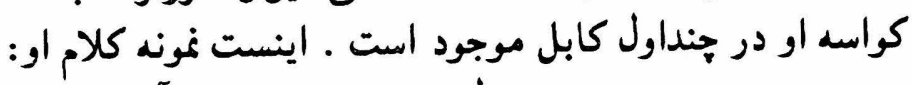

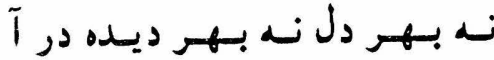

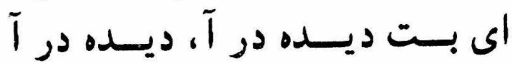

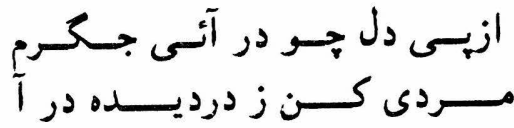

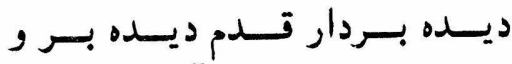

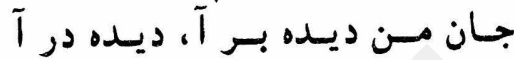

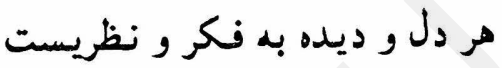

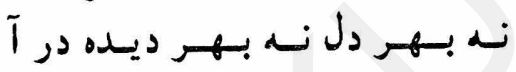

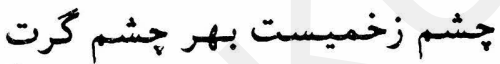

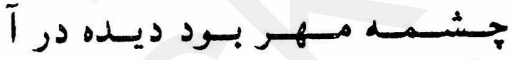

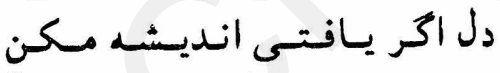

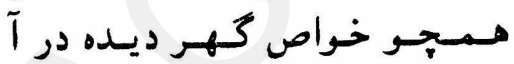

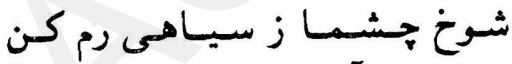

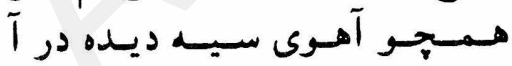

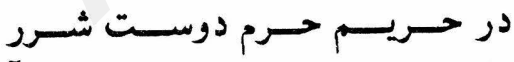

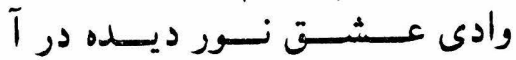

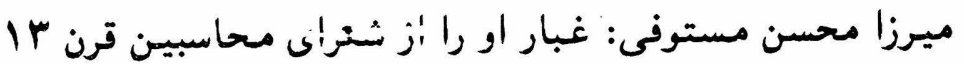

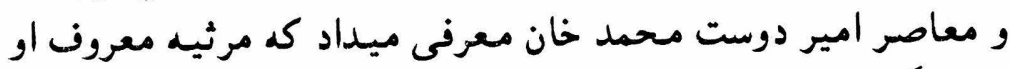

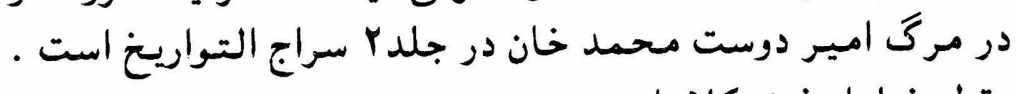

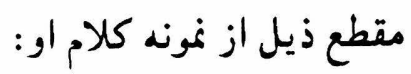

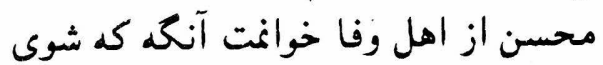
سگ دنباله رو قافله سالار حجاز 


\section{منابع}

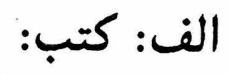

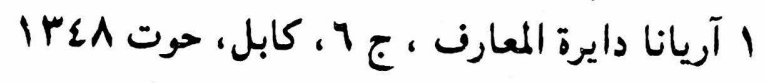

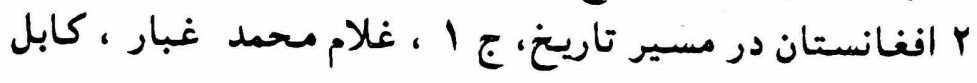
IrET r افغانستان در مسير تاريخ ، ج r r ، غلام محمد غبار ، يشاور 1999

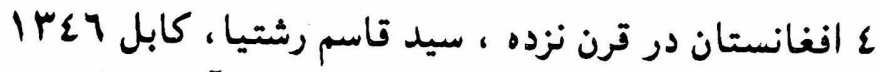

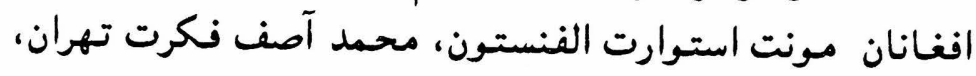
Irvr هار افغان و افغانستـان ، محمد حسن كاكر ، نشـرات يوهنتون كابل ، Irov 7 افغنانستان ، جمعى از مؤلفيـن ، نشرات انجمن آريانا دايرة المعارف، ع

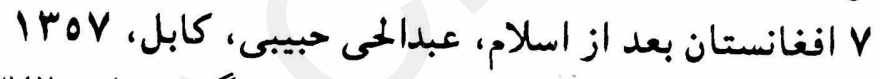

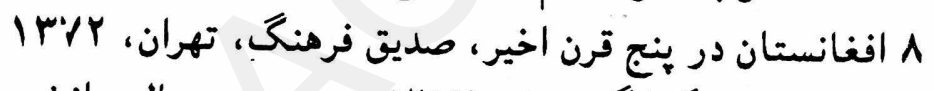

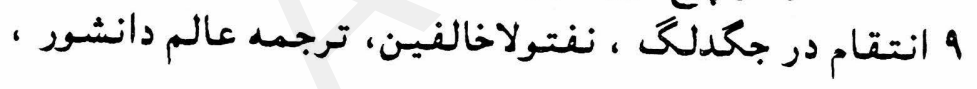
ماسكو، 1910 • 1 يادشاهان متأخر افغانستان ، يعقوب على خافى، كابل irry إئروهشى درتاريخ هزاره ها ، حسين على يزدانى بهسودى،

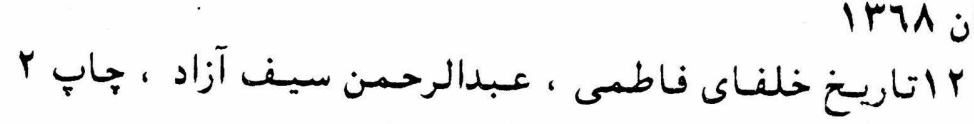

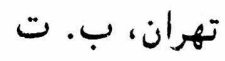




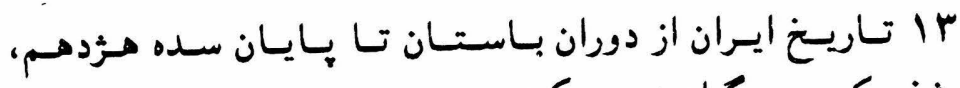

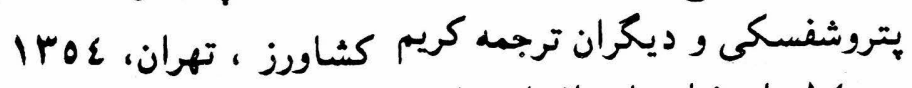

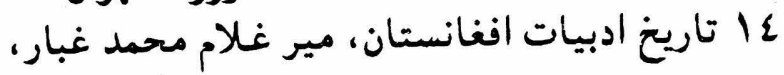

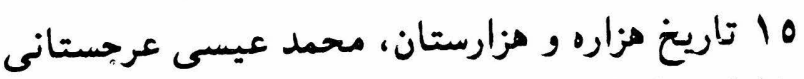

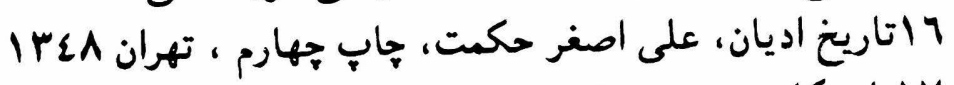

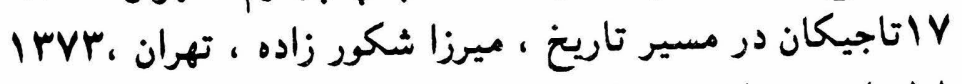

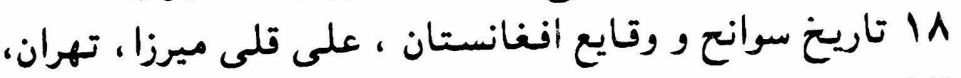

19 تاريخ خصوصى غزنى، منشى على احمد شاليزى، نسخد

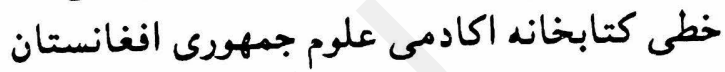

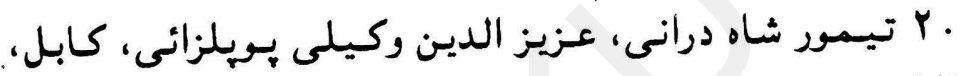
IrET

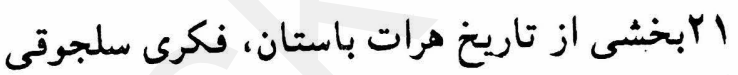

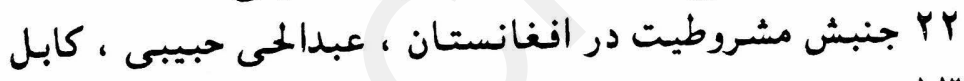
irqr

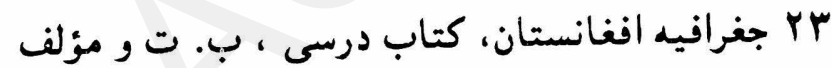

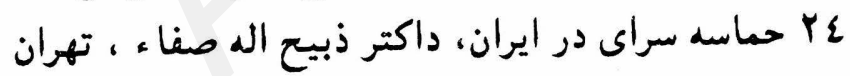

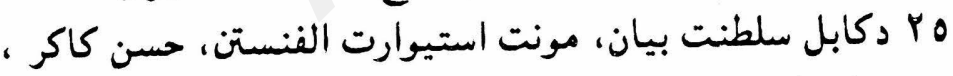

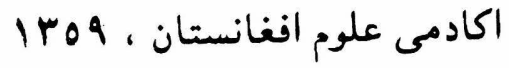

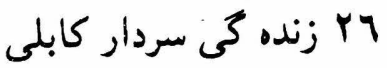

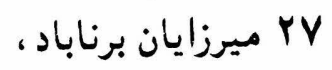

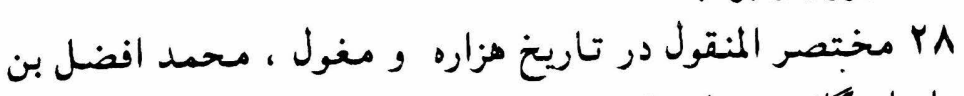

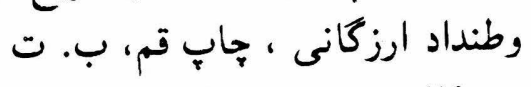

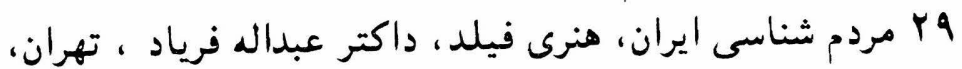


•r سركذشت ملت مظلوم افغانستان در مسير سده بيست ، غلام

$$
\text { حضرت كوشان، بشاور } 1999
$$

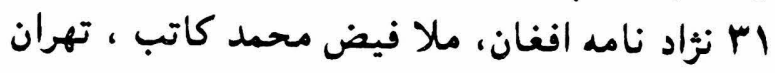

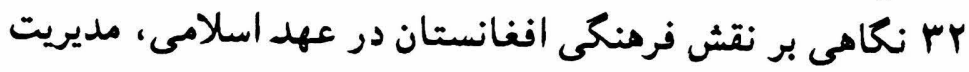

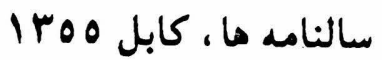

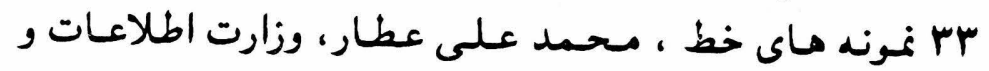

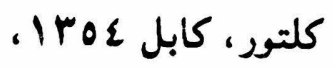

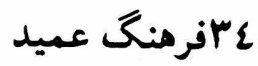

دم تبيام كابل، سرونيست آيرى، عظم الدين عليمى نسخه،

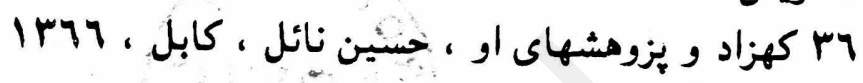

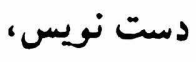

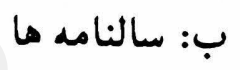

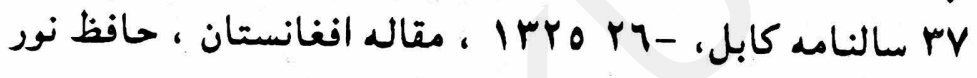

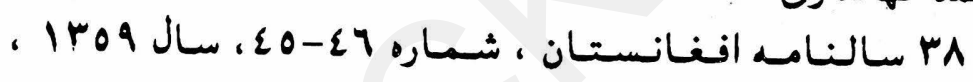

$$
\text { محمد كهكدارى }
$$

$$
\text { تاريخجه زيان ازبكىى }
$$

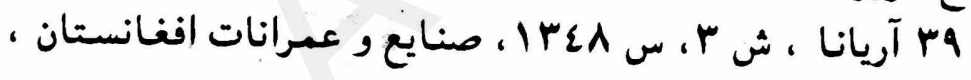

$$
\text { محمد انور نير }
$$

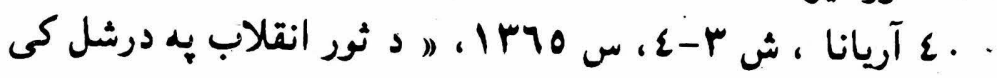

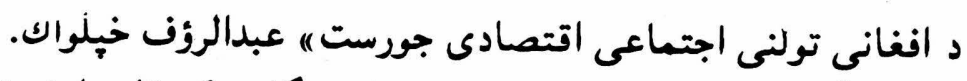

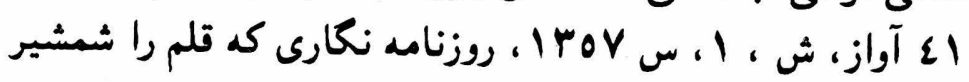
ساخت

r r آواز ، ش r r س س Irov

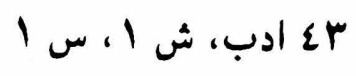

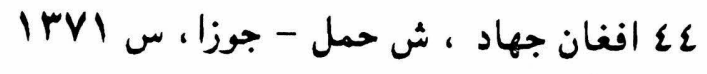




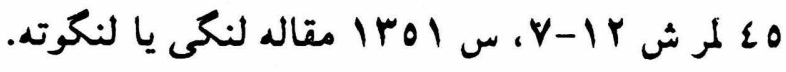

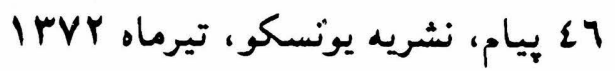

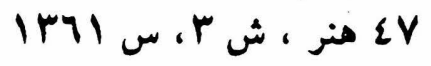

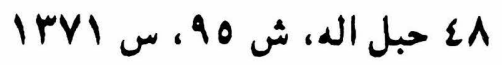

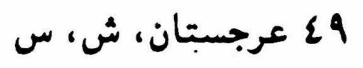

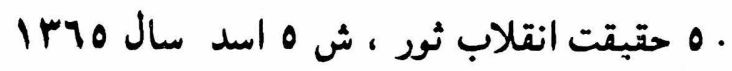
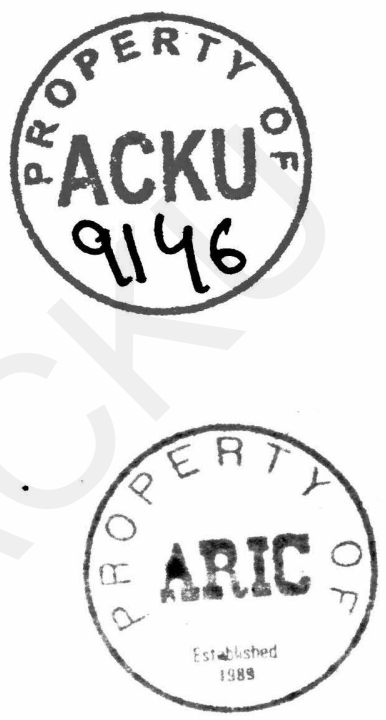


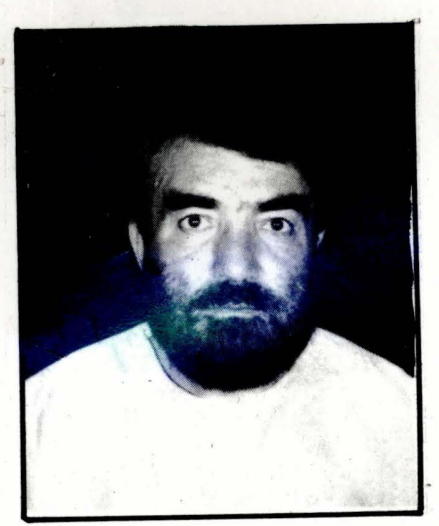

محسـد احسـان بُزروهش فـرزند مرحسوم

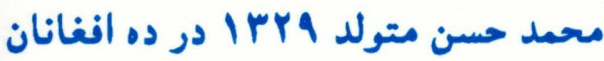

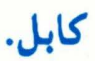
يس از نراگيري متدمات صرف و نحو عريسي و اتمام تحصيـلات ثُانوي، شـامل خدمت در ادارات دولتي كرديد. از سال r I Mor وطي بيش از يك دهه بحيث رُورناليست و عضو ميأت محرير، در مطبوعات ايفاي وظيفه نموده است. معلومات مسلكي خويش را در خارج از كثور ارتقا بخشيده

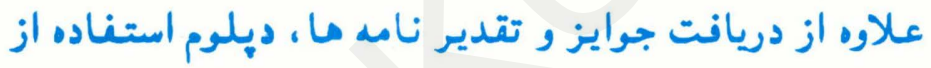

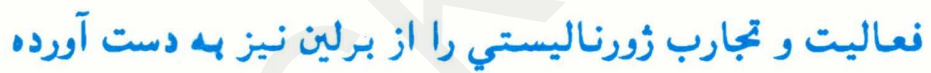
است. متالات تحـــيقي موصـوف در بسـا از مجلات كشـور جون

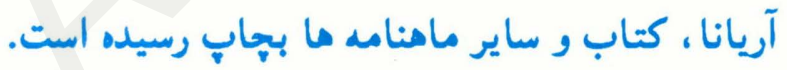

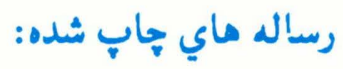
-جوانان و تحولات اجتماعي. كابل هيل - غزني تا عهد غزنويان -تاجيكان و زبان دري در افغانستان. تاشكند عزيدان

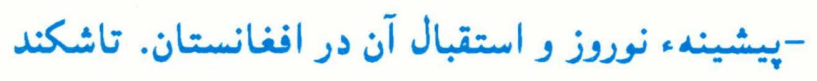

ازانتشارات كتابخانهء شس كان حاجي كمب ستى ثلاون 